\title{
Alaska's
}

Mineral

Division of Geological \& Geophysical Surveys

Division of Mining

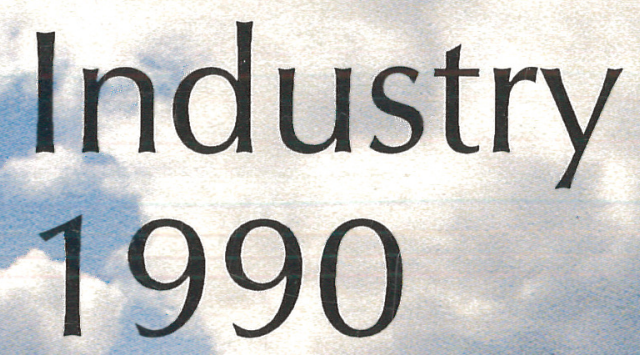

Division of Economic Development

Industry

1990

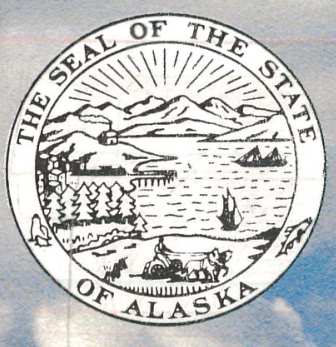

SPECIAL REPORT 45
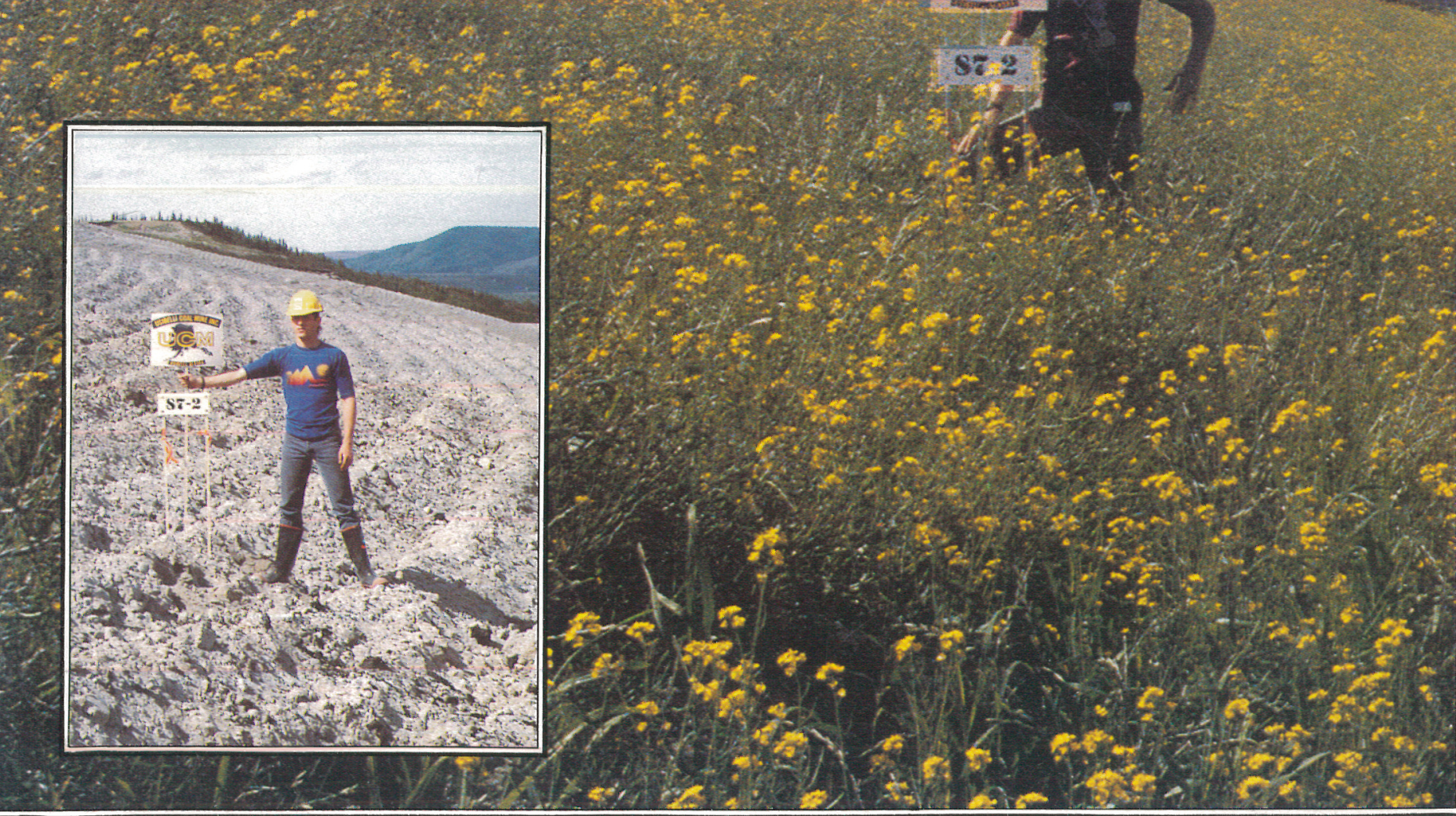


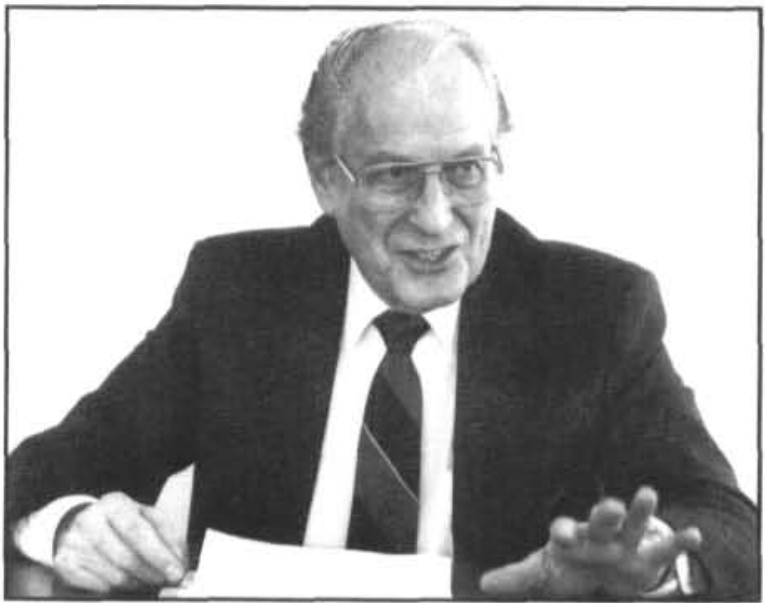

"During 1990, Alaska saw two major mines come into full production. Our world-class developments at Red Dog and Green's Creek mines not only advertise our mineral potential to the world, their success is a magnet to further exploration. The industry is key to economic development across the state. "-Dr. Glenn A. Olds, Commissioner of the Department of Commerce and Economic Development. (Photo by Margaret Bauman)

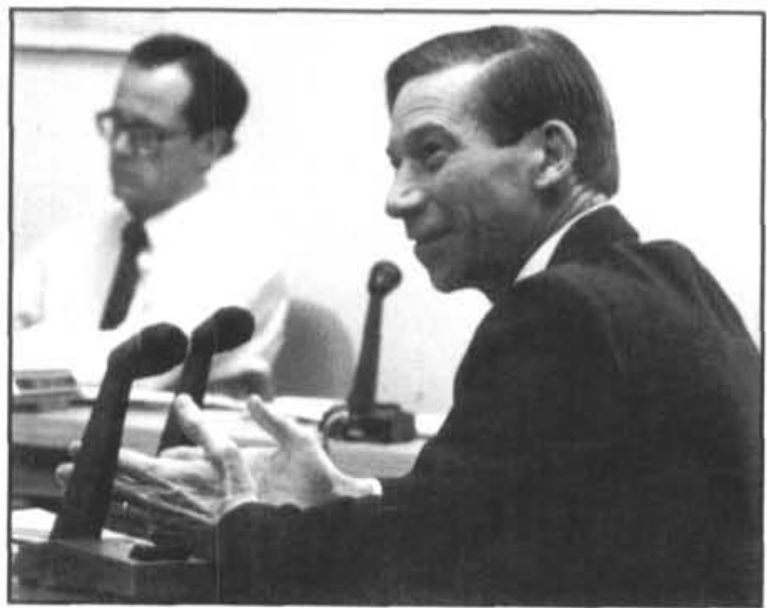

"The numbers from 1990 reveal a positive change in the health of the mineral industry in the state. Alaska has the potential to become a major mineral producer while demonstrating the technical ability to do it right environmentally. We're confident that responsible mining operators will be a credit to their communities."-Harold C. Heinze, Commissioner of the Department of Natural Resources. (Photo by Cindy Roberts) 


\section{Alaska's \\ Mineral Industry 1990}

By R.C. Swainbank, T.K. Bundtzen, and John Wood

DIVISION OF GEOLOGICAL \& GEOPHYSICAL SURVEYS

SPECIAL REPORT 45

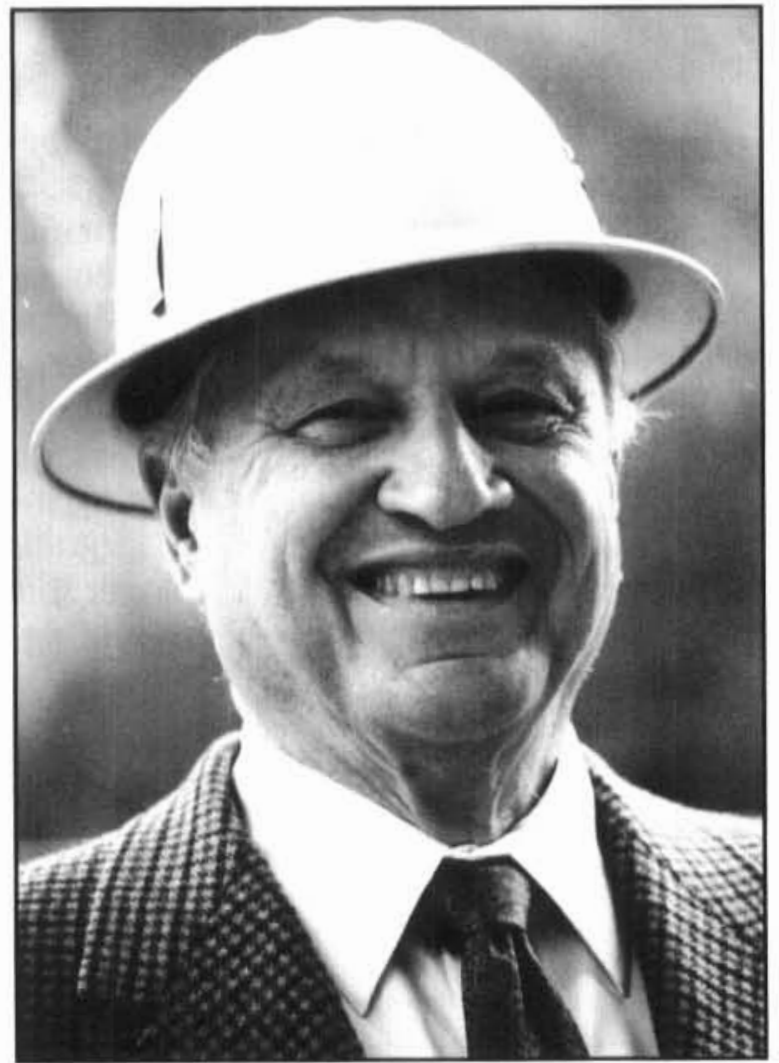

"Our message to the mining industry is, 'Yes, you are welcome here.' Our opportunity in Alaska, perhaps more than any other part of the world, is to be leaders, not followers. Our mining industry can provide a pattern environmentally and in every sense for the world at large."-Governor Walter J. Hickel. (Photo by Mark Farmer) 


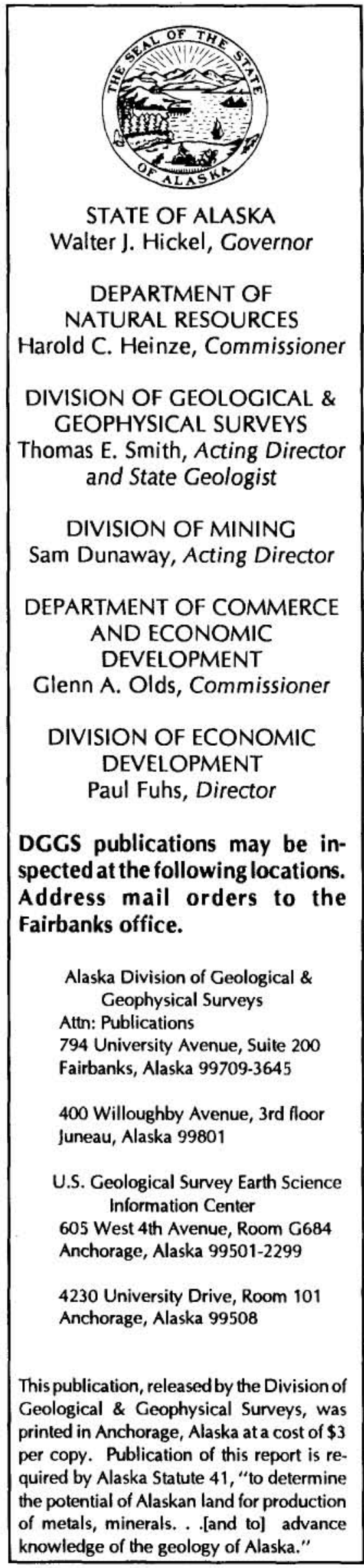

\section{EXECUTIVE SUMMARY}

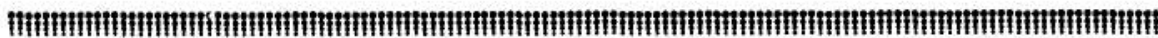

Special Report 45, "Alaska's Mineral Industry 1990," is the tenth annual report produced by the Department of Natural Resources, Division of Geological and Geophysical Surveys, the Division of Mining, and the Division of Economic Development of the Department of Commerce and Economic Development.

The report is designed to provide current, accurate, and technically reliable information about Alaska's mineral industry. The report depends on the cooperation of individuals, private industry, and government agencies to provide information on their mining projects and activities.

In 1990 the sum of expenditures for exploration and development, and the estimated value of production totaled $\$ 610.6$ million. Exploration expenditures rose to $\$ 63.3$ million, with most of the effort concentrated on hardrock gold projects, some of them in advanced stages. Development expenditures were $\$ 14.3$ million, considerably less than the $\$ 134.3$ million in 1989, mainly due to completion of development at the Red Dog' and Greens Creek mines.

Value of mineral production in 1990 was $\$ 533$ million, doubling the 1989 production value of $\$ 277$ million.

In 1990, with 55 percent of the nation's supply, Alaska led the United States in zinc production. Consequently, U.S. net import reliance for this crucial commodity decreased from 61 to 48 percent.

Alaskan silver production accounted for about 18 percent of the domestic mine production. Only Idaho and Nevada produced more.

Alaska continues to have the nation's largest placer gold mining industry, which provides jobs to many rural Alaskans.

Significant progress in land reclamation and water quality at placer mines indicate that Alaska's mining industry is capable of providing economic diversity and environmentally sound operations in the 1990s. 


\section{CONTENTS}

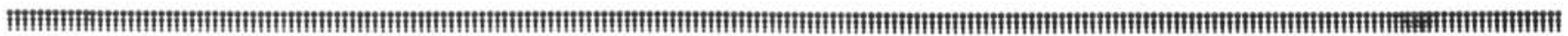

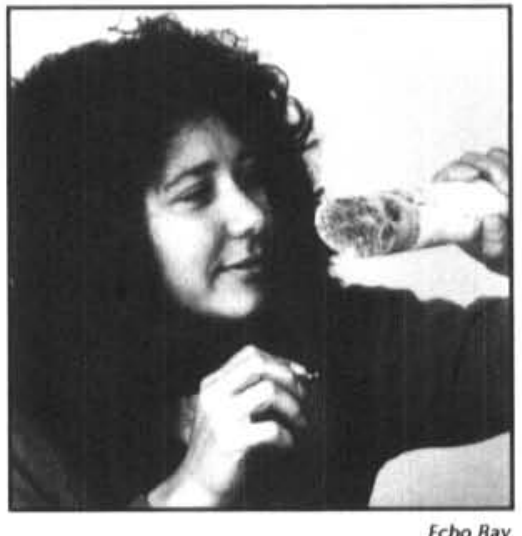

EXPLORATION Page 7

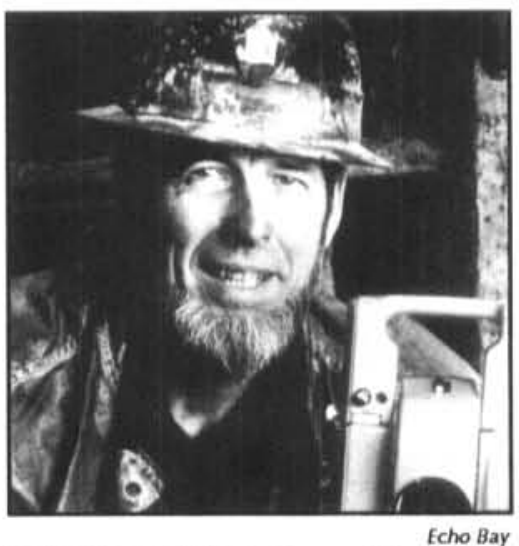

DEVELOPMENT Page 18

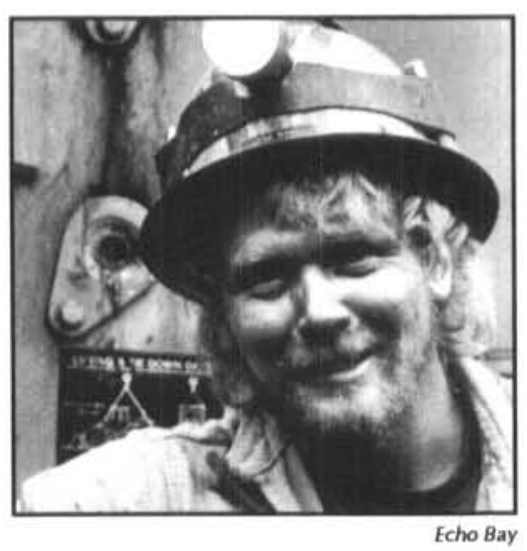

PRODUCTION Page 21
Page

ii EXECUTIVE SUMMARY

1 INTRODUCTION

1 Mineral industry activity

Employment

Exploration

Development

Production

Government actions

Education and research

6 ACKNOWLEDGMENTS

7 EXPLORATION Mineral industry exploration expenditures grew by 32 percent to $\$ 63.3$ million in 1990 . Precious metals exploration accounted for 90 percent of the total investment.

7 Introduction

7 Northern region

Metals

Coal

10

Western region Metals

11 Eastern interior region

Metals

Coal

12

Southcentral region

Metals

Coal

Industrial minerals

13 Southwestern region

Metals

Industrial minerals

13 Alaska Peninsula

Metals

Industrial minerals

14

Southeastern region

Metals

15 Advanced exploration projects

Fort Knox

Kensington

Jualin

A-J and Treadwell Mines

18 DEVELOPMENT A dramatic 90 percent decrease in mineral development expenditures in 1990 reflects the Red Dog Mine transition from development to production. Introduction

Precious metals

Base metals

Coal

Industrial minerals

21 PRODUCTION For the first time since 1925, the value of base metal production far exceeded the value of precious metals production. 


\section{Contents (continued)}

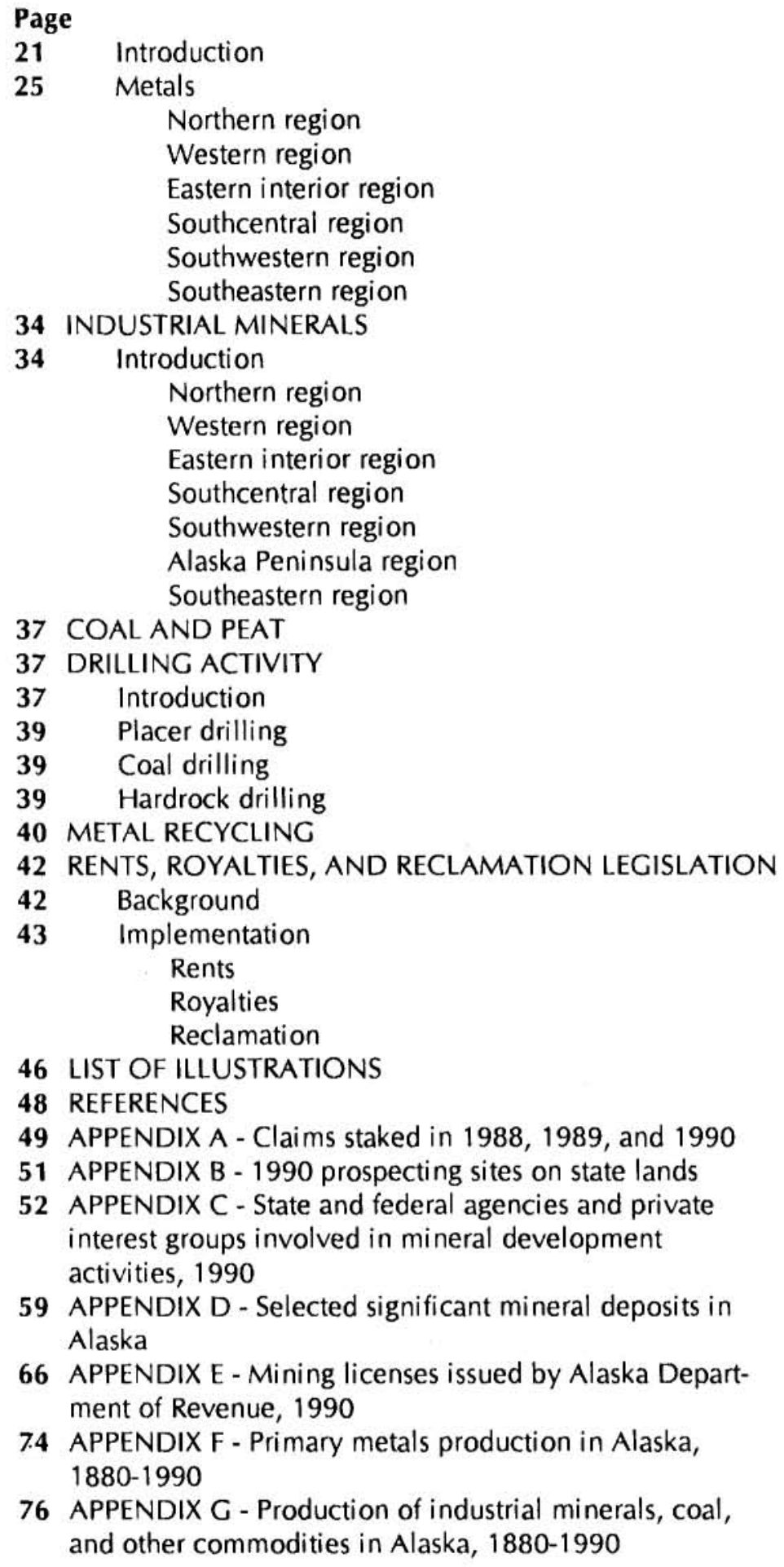

59 APPENDIX D - Selected significant mineral deposits in Alaska

66 APPENDIX E - Mining licenses issued by Alaska Department of Revenue, 1990

7.4 APPENDIX F - Primary metals production in Alaska, 1880-1990

76 APPENDIX G - Production of industrial minerals, coal, and other commodities in Alaska, 1880-1990 


\section{Alaska's}

\section{Mineral Industry 1990}

By R.C. Swainbank, ${ }^{1}$ T.K. Bundtzen, ${ }^{2}$ and John Wood ${ }^{3}$

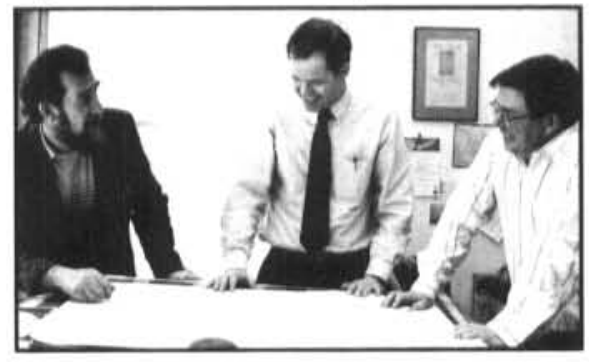

Authors of the "Alaska Mineral Industry Report, 1990" discuss the results of their data gathering. Left to right: Dick Swainbank, Division of Economic Development, Department of Commerce and Economic Development, John Wood, Division of Mining, and Tom Bundtzen, Division of Ceological and Geophysical Surveys, Department of Natural Resources. (Photo by Cindy Roberts)

\section{INTRODUCTION}

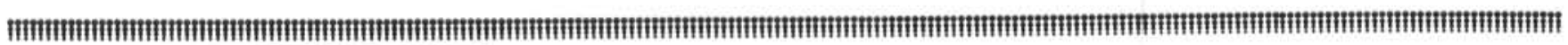
MINERAL INDUSTRY ACTIVITY

Alaska's mineral industry in 1990 showed positive gains in metallic production and exploration expenditures while industrial mineral activities stabilized.

Continuing the upward trend which began in 1987, exploration expenditures reported in 1990 were $\$ 63.3$ million (fig. 1). These expenditures represent an increase of 32 percent over the $\$ 47.8$ reported in 1989 and were predominantly invested in advanced hardrock gold projects. Some of these projects might proceed to development in 1991 or 1992.

Development expenditures declined dramatically to $\$ 14.3$ million in 1990 from $\$ 134.3$ million in 1989 , which was in turn a decline from \$275 million in 1988 (fig. 2). This decline reflects the shift from development to production modes at the Greens Creek and Red Dog mines.

\footnotetext{
'Alaska Division of Economic Development, 1001 Noble St., Ste. 360, Fairbanks, AK 99701.

2Alaska Division of Geological and Geophysical Surveys, 794 University Ave., Ste. 200, Fairbanks, AK 99709-3645.

${ }^{3}$ Alaska Division of Mining, 3700 University Ave., Fairbanks, AK 99709.
}

The value of mineral production in Alaska doubled in value from $\$ 277$ million in 1989 to about $\$ 533$ million in 1990 (fig. 3 ). All of the increase was due to production of zinc, lead, and silver concentrates. The 1990 total value of Alaska's mineral industry as measured by the additive value of exploration, development, and production was \$610.6 million, 33 percent higher than the 1989 estimate of $\$ 459$ million (table 1, fig. 4).

\section{Employment}

Table 2 shows the employment statistics for the mineral industry for the last three years.

Generally, fewer workers are needed to operate a producing mine than to construct a new mine; the decline in employment during the last three years reflects the shift from construction (mineral development) to production at the Red Dog and the Greens Creek mines. Concurrent with that change, employment has increased in base metal and hardrock precious metal mining from 99 in 1987 , to 690 in 1990.

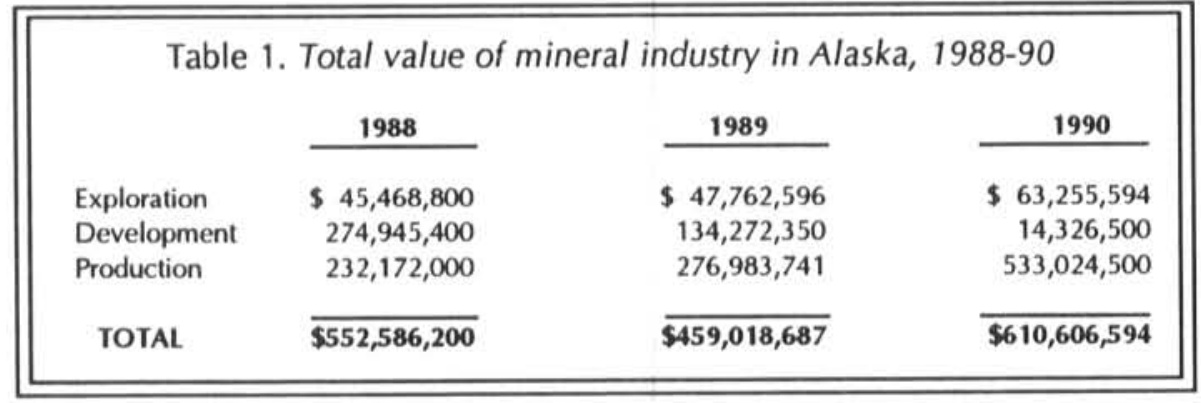




\section{Exploration}

Exploration expenditures increased to $\$ 63.3$ million in 1990, up 32 percent from the $\$ 47.8$ million in 1989 , which was in turn an increase from $\$ 45.5$ million in 1988. This increase is in contrast with a marked decline in the neighboring Yukon Territory during the same period. Returns from 109 mining firms and small partnerships working in Alaska show that precious metals exploration accounted for 90 percent of the total mineral exploration expenditures. Base metal and coal exploration accounted for 8.4 percent and 0.5 percent respectively. There were 374 individuals employed full-time in mineral exploration.

Four major hardrock gold

\section{EXPLORATION}

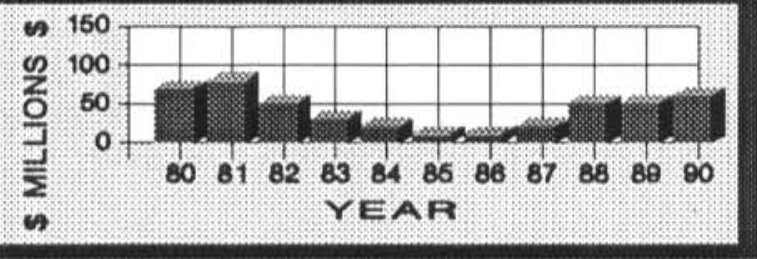

ure 1. Exploration expen tures reported, 1980-90.

Figure 2. Development expenditures reported, 1980-90.

\section{DEVELOPMENT}
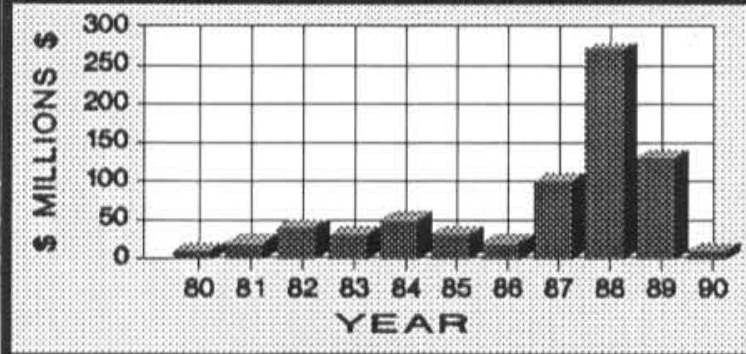

\begin{tabular}{|c|c|c|c|}
\hline \multicolumn{4}{|c|}{ Table 2. Alaskan mine employment, 1988-90 } \\
\hline & 1988 & 1989 & 1990 \\
\hline \multicolumn{4}{|l|}{ Gold/silver mining } \\
\hline Placer & 1,206 & 1,316 & 1,151 \\
\hline Lode & 99 & 161 & 265 \\
\hline Base Metals & .. & 407 & 425 \\
\hline Recreational & 350 & 325 & 315 \\
\hline Sand and gravel & 752 & 625 & 645 \\
\hline Building stone & 210 & 148 & 160 \\
\hline Coal & 120 & 120 & 115 \\
\hline Peat & -. & -. & .. \\
\hline \multicolumn{4}{|l|}{ Tin, jade, soapstone } \\
\hline ceramics, platinum & 40 & 40 & 40 \\
\hline Mineral development & 1,294 & 785 & 95 \\
\hline Mineral exploration` & 323 & 350 & 374 \\
\hline TOTAL & 4,394 & $\overline{4,277}$ & 3,585 \\
\hline
\end{tabular}


region, ACNC, Placer Dome U.S., Inc., Echo Bay Mines, Lac Minerals, Pulsar

Resources (U.S.), Inc., Hecla, BHP-Utah, and Kennecott Exploration, Inc.

\section{Development}

Mineral development expenditures in 1990 totaled $\$ 14.3$ million, a 90 percent reduction from the $\$ 134$ million in 1989 . This reduction reflects the end of the development phase of the Red Dog mine and the change to production.

Alaska Gold continued thawfield drilling at their Nome placer operations, and Cambior continued development drilling at their Valdez Creek placer mine near Cantwell, central Alaska. Cambior also started a major diversion of the creek to allow the upstream advance of their open-pit operations.

Feasibility studies for coal development by Indemitsu-Alaska at their Wishbone Hill Mine near Palmer, and by Diamond Alaska at their Chuitna Coal Project west of Anchorage accounted for the remainder of the development expenditures.

\section{Production}

For the first time since 1925 the value of base metals produced in Alaska far exceeded the value of precious metals in 1990 (appendix F). The estimated value of zinc and lead, $\$ 284.6$ million, accounted for over half the total value of mineral production in the state, and was double the value of gold and silver production. Much of the base metal produced was from the Red Dog Mine of Cominco Alaska, Inc. Although the mine shipped only 320,000 tons $(290,240$ tonnes) of concentrate in 1990, Cominco has estimated that it will ship over 700,000 tons $(634,900$ tonnes) of concentrate per year when the mine is at full production. So, unless there is a drastic fall in the price of lead and zinc, it is likely that base metals will continue to capture a major share of metallic mineral production in

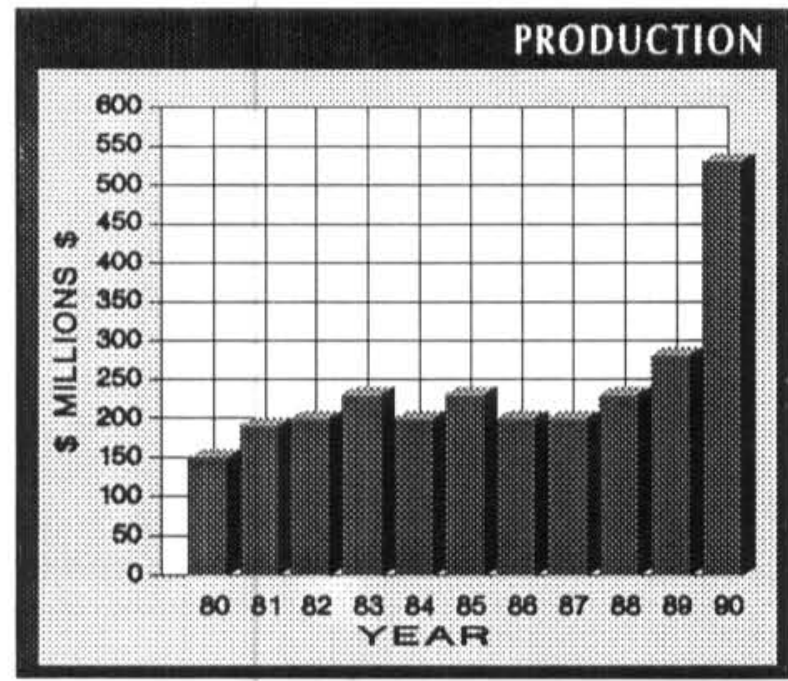
future years.

Kennecott mined about 382,000 tons ( 346,470 tonnes) of sulfide ore at Greens Creek Mine and produced about 37,000 tons (33,600 tonnes) of zinc, 16,730 tons $(15,175$ tonnes) of lead, $38,103 \mathrm{oz}(1,182 \mathrm{~kg})$ of gold and $7.6 \mathrm{mil}-$ lion oz $(235,812 \mathrm{~kg})$ of silver in concentrates. For the second consecutive year the mine was the nation's largest producer of silver.

Total production of gold in 1990, estimated at $231,700 \mathrm{oz}$ $(7,206 \mathrm{~kg})$, was down substantially from 1989 because of poor production by Westgold's BIMA dredge, and because the Valdez Creek placer mine operated by Cambior was closed for most of the year for diversion of the creek. Only about $40,300 \mathrm{oz}(1,251 \mathrm{~kg})$, of hardrock gold was produced in 1990, with $38,100 \mathrm{oz}(1,183 \mathrm{~kg})$ from Greens Creek Mine and most of the remainder from Citigold Alaska's, Ryan Lode Mine near Fairbanks.

Usibelli Coal Mine near Healy, in central Alaska, produced 1.576 million tons (1,429 million tonnes) of coal worth about $\$ 45$ million, a new production record. Of this about half of the total was exported to Korea, and the rest used locally.

With no major development projects in the state in 1990, rock, and sand and gravel production was slightly higher than in 1989, with a combined total of 18.2 million tons, (16.6 million tonnes), with a value of about $\$ 62.9$ million.

Figure 4. Total mineral industry expenditures reported, 1980-90.

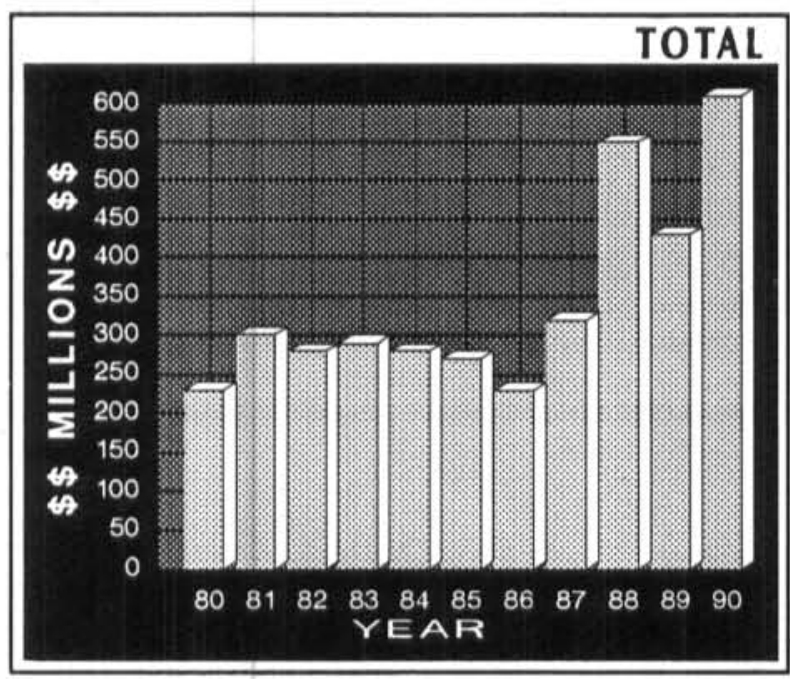




\section{Government Actions}

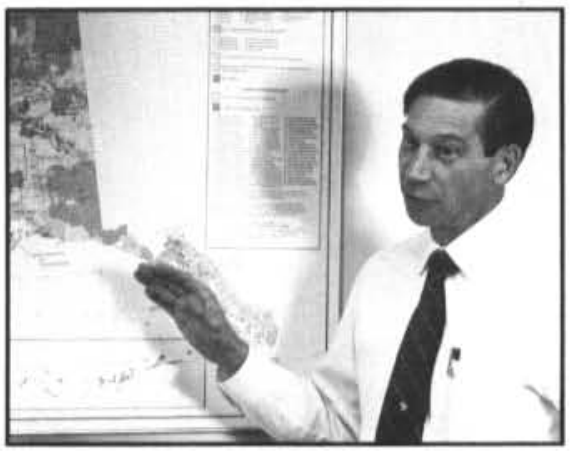

Figure 5. In the first few weeks of the current state government administration, Commissioner Heinze initiated a department-wide effort to complete the selection of the final 20-million acres of land of the state's entitlement under the statehood act. Land selection will focus on mineral potential, access, and ownership patterns. (Photo by Cindy Roberts)

Figure 6. Dr. Earl Beistline, chairman of the Alaska Minerals Commission, discusses pending legislation with Dr. Richard Swainbank, Commission development specialist. The Commission acts in an advisory capacity to the legislature and to the executive branch of state government. (Photo by Cindy Roberts)

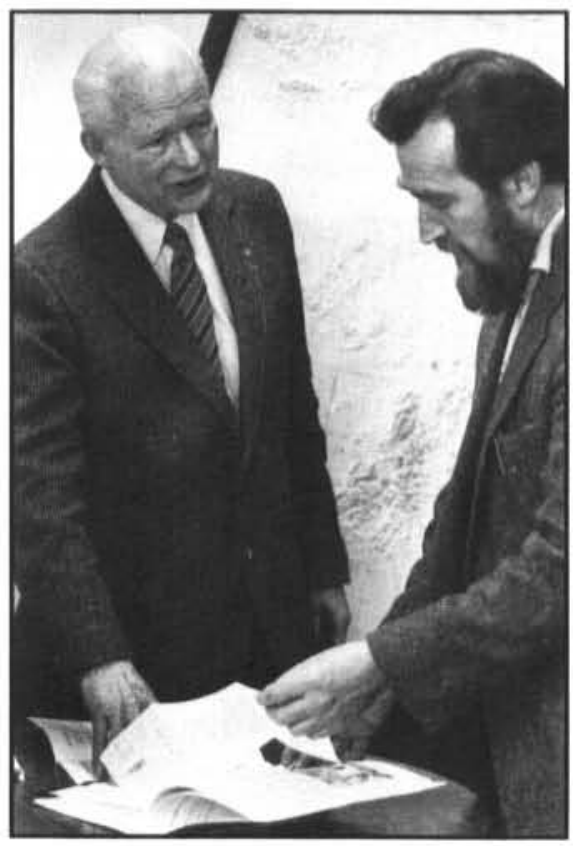

In 1990, all claims on state land became subject to rental and net royalty fees as a result of legislation signed by Governor Cowper. Reclamation requirements were established for state, federal, and private lands.

Rent was backdated to 1989 , with payment due in June 1990, and rents for 1990 were due by November 30, 1990. Revenue for 1989 was $\$ 641,000$, and for 1990 increased to $\$ 653,080$.

Regulations supporting reclamation legislation are expected to include a performance bonding provision. Regulations are discussed in more detail beginning on p. 42, "Rents, Royalties, and Reclamation."

In 1990, the mineral industry was greatly impacted by the Weiss v. State of Alaska lawsuit which demanded the resolution of many issues surrounding the Alaska Mental Health Land Trust. This 1985 suit demanded the reconstitution of the 1-million-acre trust established prior to statehood in order to support instate mental health programs. The 1978 legislature changed the status of unsold and unencumbered trust lands to general grant state land. As a result, lands were conveyed to municipalities and private owners. The provision for automatic revenue flow to the trust was ignored and the lawsuit by trust beneficiaries followed.

Legislation passed in 1990 to provide a guaranteed revenue stream for the trust. However, a Superior Court ruling placed an injunction on the conveyance or permit issuance on any of the original acreage. These lands were selected for their income potential from mineral, coal, and timber development, and many properties became third parties in the lawsuit.

The legislation affected exploration plans for Usibelli properties, but it shut down the Wishbone Hill coal project owned by Idemitsu-Alaska. NOTE: The Hickel administration and the 1991 Legislature crafted a settlement agreement to resolve the lawsuit. As of press time, it has not gone before the judge. If accepted, it will clear title on the original trust land and open 1 million acres for development to benefit the mental health groups.

The November 1990 election returned Walter J. Hickel, Alaska's second governor, to Juneau with former senator from Nenana Jack Coghill as his lieutenant governor. The election reflected a shift to a pro-development philosophy.

In December, Department of Natural Resources Commissioner Harold C. Heinze established as a priority during the next two years to select the lands that will complete the state's entitlement of 104.5 million acres.

\section{Education and Research}

The Alaska Miners Association (AMA) hosted 11 geologists and mining engineers from the Soviet Far East at their November 1990, 15th Annual Miners Association Convention in Anchorage. The Soviets traveled from Provideniya (USSR) to Nome on charter flights flown by Bering Air and arranged by AMA. The arrival in Nome of the large geoscience contingent marked a symbolic return to Russian America (fig. 7).

The technical sessions comparing the geology and mineral deposits of Alaska, Canada and the Soviet Far East were co-chaired by the Alaska Division of Geological and Geophysical Surveys, and the U.S. Geological Survey. Over 
420 people registered for the three day convention, the best attendance since 1981. Soviet and American speakers presented papers on placer geology, engineering geology, regional geology and geophysics, ore deposit summaries, and regional metallogenesis. Table 3 lists the speakers at the symposium. Workshops were held over the weekend to encourage informal dialogue between the Soviet geologists and their counterparts in Alaska (fig. 8).

Two geologists, Farid Kutyev and Leonid Parfenov from Yakutsk traveled to Fairbanks to lecture at the University of Alaska Geology Department and met with collaborators on several joint projects. The AMA is currently editing papers submitted by those who participated in the symposium; a full journal is expected to be released in 1991.

Table 3. Soviet participants in geology and metallogeny of Soviet Far East, Alaska, and Canada Symposium

Dr. Eugene Bogdanov

Director, Mining Institute U.S.S.R. Academy of Sciences, Khabarovsk

Dr. Chermen Borukayev, Director Institute of Tectonics and Geophysics U.S.S.R. Academy of Sciences, Khabarovsk

Ms. Lidiya Kovbas, Assoc. Director for International Relations Far East Geological Institute U.S.S.R. Academy of Sciences, Vladivostok

Dr. Farid Kutyev, Chief Laboratory on Petrology and Metallogenesis Institute of Volcanology U.S.S.R. Academy of Sciences, Petropavlovsk-Kamchatsky

Dr. Ivan Nekrasov, Director Far East Geological Institute U.S.S.R. Academy of Sciences, Vladivostok

Dr. Leonid Parfenov, Chief Laboratory on Regional Geology Yakut Institute of Geology Siberian Department U.S.S.R. Academy of Sciences, Yakutsk

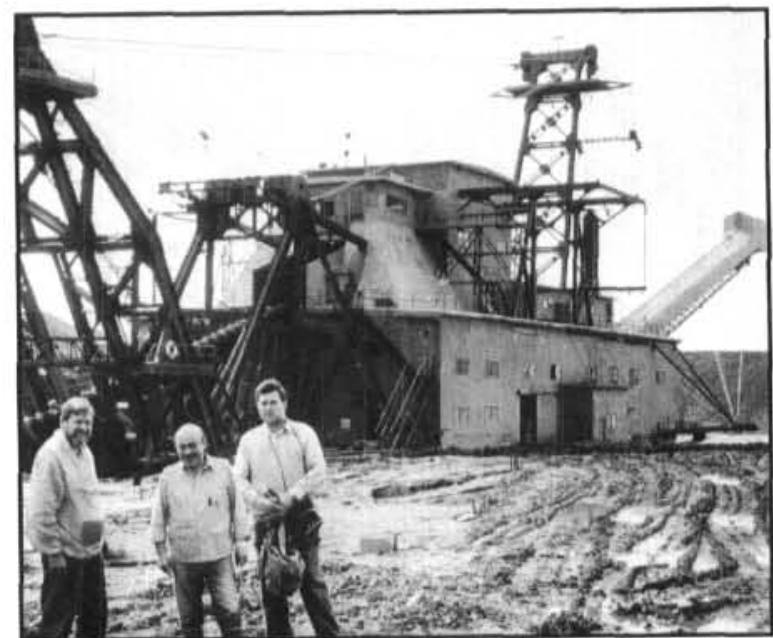

Figure 7. During 1990, Alaskans had many opportunities to visit with their professional counterparts in the Soviet Far East. Geologists from the USSR Ministry of Geology and Academy of Science inspect Alaska Gold Company's dredge \#5 in the Nome goldfields. The geologists participated in an exchange with USCS and Alaska DCCS personnel. Many similarities were found between the mineral districts of Alaska and those in the Magadan region of the Soviet Far East. (Photo by T.K. Bundtzen)
Figure 8. At a farewell dinner in Anchorage, colleagues from the Soviet Union, Alaska, and Canada celebrate their common scientific enthusiasm and new friendships. (Photo by Warren Nokleberg

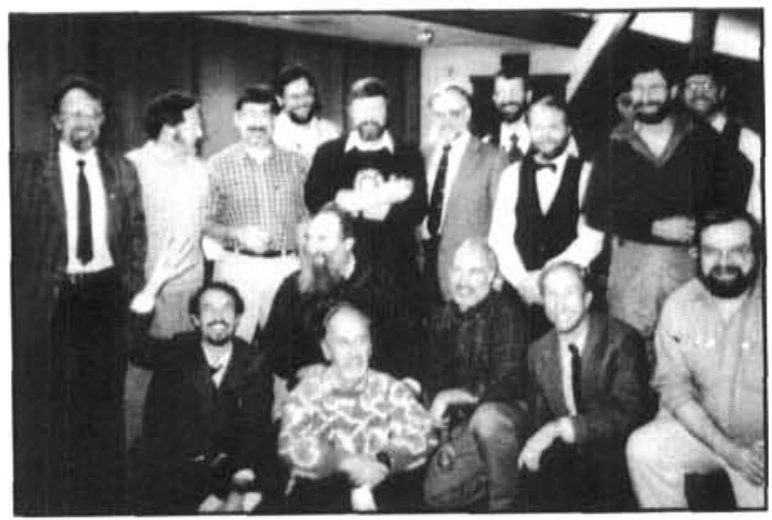




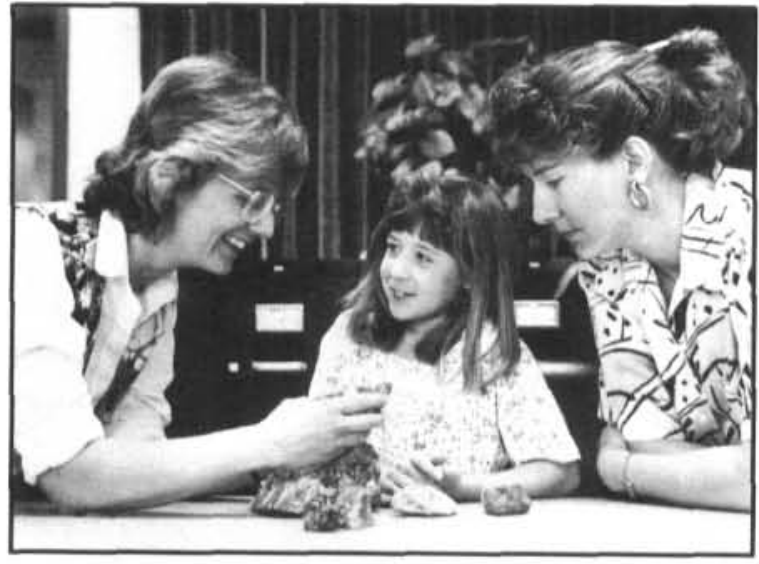

Figure 9. The Alaska Mineral and Energy Resource Eduction Fund (AMEREF) celebrated its eighth year of operation in 1990. This joint venture between Alaska's mineral industry and the Alaska Department of Education has provided nearly 500 schools across the state with teaching materials ranging from a sample rock kit to detailed geologic lesson plans. The kits can be adapted for use in classrooms from first grade through high school. Here, both teacher and student examine rock samples with a DCCS geologist. (Photo by Cindy Roberts)
Two Alaska programs continue to provide mining vocational training. The Mining and Petroleum Training Service (MAPTS) is based in Soldotna and predominantly serves southcentral Alaska. The Institute of Mining Technology (IMT) of the University of Alaska Southeast is based in Juneau. IMT is a partnership between the University and the mining industry. This program provides training for a variety of mine and mining-related vocations and has over 80 percent placement rate of its graduates. With Alaska's expanding minerals production sector, these programs play an important role in providing a well-trained workforce for the industry.

The Alaska Science and Technology Foundation (ASTF) awarded a grant to Goldstream Exploration Inc. of Fairbanks to design a placer mining plant that can meet reclamation and water quality standards required in state and federal law. A $40 \mathrm{yd} / \mathrm{hr}$ demonstration plant operated for part of the 1990 season. A full scale plant is expected to be in operation during the 1991 placer mining season. The ASTF was designed to provide matching funds for selected proposals tailored to enhance the Alaskan economy.

The Fairbanks Historic Preservation Foundation announced plans to raise funds to purchase buildings and land of the original headquarters of the United States Smelting, Refining, \& Mining Co. (USSR\&M). This company was a major employer in Fairbanks prior to statehood. Plans include restoration and educational presentations at the site.

The Alaska Mineral and Energy Resource Education Foundation (AMEREF) continued the resource education curriculum (fig. 9). Since 1985 AMEREF has placed resource education kits in 490 Alaskan elementary and secondary schools (Tunley, 1990).

\section{ACKNOWLEDGMENTS}

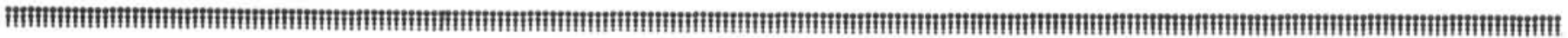

This report is designed, produced, and distributed by the Alaska Department of Natural Resources, Division of Geological and Geophysical Surveys (DGGS), Division of Mining (DOM), and the Department of Commerce and Economic Development, Division of Economic Development (DED).

We thank many people for supplying data for this report: Alaskan mining exploration firms, placer miners, mine production companies, metal recycling firms, sand-and-gravel and other producers, Native Regional Corporations, and federal, state, and municipal agencies.
T.K. Bundtzen (DGGS) and Ellen Harris (DGGS) mailed out about 1,050 questionnaires on mining activity, 214 of which were returned by private firms, agencies, and individuals.

R.C. Swainbank (DED) and Bundtzen wrote the Introduction; Swainbank wrote the Exploration, Drilling and Development Sections; Bundtzen wrote the Production and Metal Recycling Sections, and J.E. Wood (DOM) produced the section on Rents, Royalties and Reclamation. All authors updated appendixes C-G; Erik Hansen (DOM) compiled appendixes $\mathrm{A}$ and $\mathrm{B}$.
We want to acknowledge the following people for their contributions to the production of this report: Cindy Roberts (DNR), ideas and inspiration for the new format of this edition; A-L Schell (DGGS), design, graphics layout, and production coordination; G.M. Laird, computer graphics; R.A. Mann (DGGS), desktop publishing; F.C. Tannian (DGGS), editing; Cindy Roberts, T.K. Bundtzen, and R.C. Swainbank, photograph selection. For reviewing the document, we wish to thank M.W. Henning (DGGS), B.W. Campbell (DOM), and A.H. Clough (DED). 


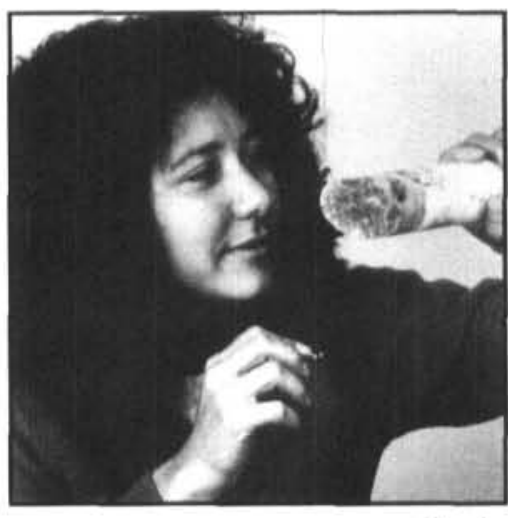

Echo Bay

\section{EXPLORATION}

\section{Mineral industry exploration expenditures grew by 32 percent to $\$ 63.3$ million in 1990. Precious metals exploration accounted for 90 percent of the total investment.}

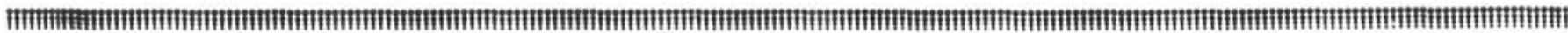

\section{INTRODUCTION}

Exploration expenditures in Alaska in 1990 were $\$ 63.3$ million, up 32 percent from $\$ 47.8$ million in 1989 , continuing the trend which began in 1987. About 60 percent of these funds were invested in bulk minable gold properties; three are advanced exploration projects near Juneau, and one project is near Fairbanks. However, significant expenditures were made in all areas of the state.

The increase in expenditures was encouraging, particularly because exploration has been declining in neighboring Canada during the last two years. It is anticipated that one or more of the advanced exploration projects will proceed to mine development in the next few years, and, ultimately, to production.
Tables 4 and 5 show the distribution of the exploration expenditures by type of commodity and by region. Numbers of persons employed in exploration is also shown by region in table 5 .

Figure 10 illustrates locations of selected exploration projects described in the following chapter. Figure 11 illustrates trends in exploration during the last 35 years. In 1990 , as in past years, exploration expenditures for precious metals far outweighed those for other metals or material, and most exploration effort was again in southeast Alaska both in terms of capital and people employed (table 5).

Figures 12 and 13 show the number of new claims filed in Alaska annually since 1970, and assessment work filed for the same period. In 1990 new state claims numbered 2,573 and 1,888 new federal claims were staked, compared with 3,928 and 1,664 respectively in 1989. Royalties on state claims increased from $\$ 641,000$ for 1989 to $\$ 653,000$ in 1990. Active claims in 1990 totaled 62,528 , a decrease of 8 percent from 67,948 in 1989.

\section{NORTHERN REGION}

The northern region covers about 30 percent of Alaska's landmass and includes some of the state's least populated and most remote geographic areas, such as the Brooks Range and North Slope. Reported 1990 expenditures totaled $\$ 1,152,000$ up a little from the $\$ 983,000$ reported 1989 . Nine

Table 4. Reported exploration expenditures in Alaska by commodity, 1983-90

\begin{tabular}{|c|c|c|c|c|c|c|c|c|}
\hline & 1983 & 1984 & 1985 & 1986 & 1987 & 1988 & 1989 & 1990 \\
\hline Base metals & \$ $9,758,760$ & \$ $4,720,596$ & $\$ 2,397,600$ & $\$ 1,847,660$ & \$ $2,523,350$ & $\$ 1,208,000$ & \$ $3,503,000$ & $\$ 5,282,200$ \\
\hline Precious metals & $20,897,555$ & $14,948,554$ & $6,482,400$ & $6,107,084$ & $11,743,711$ & $41,370,600$ & $43,205,300$ & $57,185,394$ \\
\hline Industrial minerals & $2,068,300$ & 270,000 & $\ldots$ & 170,000 & 286,000 & 160,200 & 125,000 & 370,000 \\
\hline Coal and peat & $1,338,454$ & $2,065,000$ & 270,000 & 790,000 & $1,150,000$ & $2,730,000$ & 924,296 & 321,000 \\
\hline Other & 70,000 & 279,500 & - & - & 31,000 & $\cdots$ & 5,000 & 97,000 \\
\hline TOTAL & $\$ 34,133,069$ & $\$ 22,283,650$ & $\$ 9,150,000$ & $\$ 8,914,744$ & $\$ 15,734,061$ & $\$ 45,468,800$ & $\$ 47,762,596$ & $\$ 63,255,594$ \\
\hline
\end{tabular}

- - No expenditures reported.

\%ade, platinum, diamonds, and colored gemstones. 


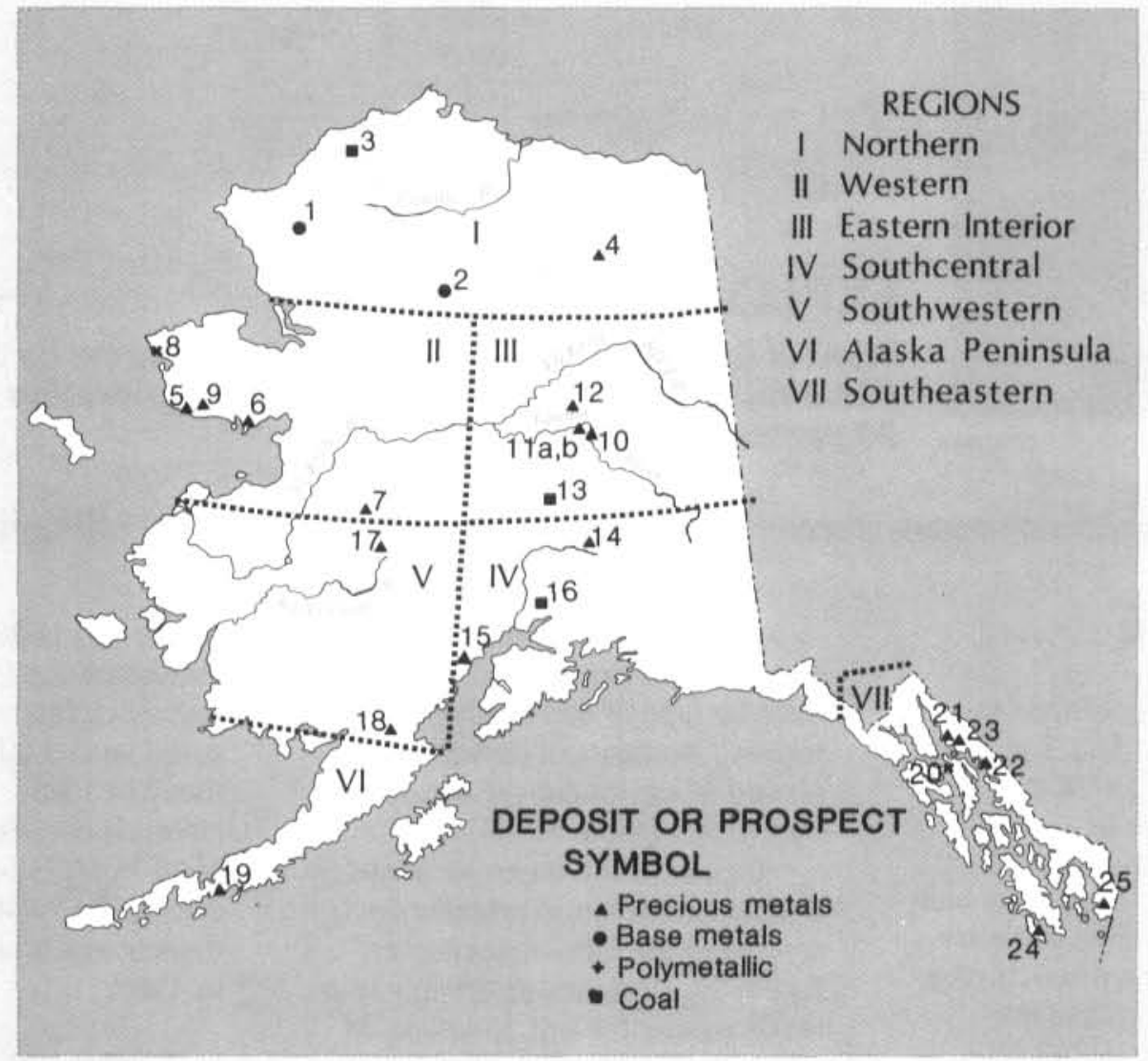

\section{NORTHERN REGION (I)}

1. Moneta-Porcupine Mines (Lik Deposit)

2. Cominco Alaska Exploration (Ambler Copper Belt)

3. Arctic Slope Consulting Group (Deadfall syncline)

4. Gold Dust Mines, Inc. (Chandalar Camp)

\section{WESTERN REGION (II)}

5. Tenneco Minerals (Rock Creek)

6. BHP-Utah International (Bluff)

7. Vinta Explorations, Ltd. (IIlinois Creek)

8. Kennecolt (Potato Mountain)

9. Cyprus Gold (Nome placers)

\section{EASTERN REGION (III)}

10. Fairbanks Gold, Inc. (Fort Knox) 11a. American Copper \& Nickel Company, Inc. (Ester Dome)

11b. Citigold Alaska, Inc. (Ester Dome)

12. Fairbanks Exploration, Inc. (Livengood, Fairbanks, Circle)

13. Usibelli Mines, Inc. (Healy)

\section{SOUTHCENTRAL REGION (IV)}

14. CanAlaska Resources, Ltd. (Rainbow Hill project)

15. Hunt, Ware \& Proffett (Johnson River)

16. Hobbs Industries, Inc. (Castle Mountain Mine)

\section{SOUTHWESTERN REGION (V)}

17. Battle Mountain Exploration Company (Independence Mine)

18. Cominco Alaska Exploration (Pebble Beach)
ALASKA PENINSULA (VI)

19. Battle Mountain Exploration Company (Centennial)

\section{SOUTHEASTERN REGION (VII)}

20. Kennecott Greens Creek Mining Company (Greens Creek Mine)

21. Echo Bay Exploration, Inc. (Kensington)

22. Echo Bay Exploration, Inc. (A- $-1 /$ Treadwell)

23. Placer Dome (U.S.), Inc. (Jualin Mine)

24. Sealaska Corporation (Dall Island)

25. Pulsar Resources (U.S.), Inc. (Hyder District) 
companies reported 4,650 workdays of employment on precious, base metal, and coal projects.

\section{Metals}

Cominco Alaska Exploration was active in northwest Alaska drilling near the Red Dog deposit, and also at the Smucker and Sun base metal deposits at the west and east ends of the Ambler Copper Belt (fig. 14). Moneta-Porcupine Mines, as part of an agreement to purchase a 50 percent interest in the Lik prospect from General Crude Oil (GCO) Minerals, drilled three holes to provide samples for metallurgical tests. The other 50 percent is presently owned by Echo Bay Mine and, by spending $\$ 25$ million over the next 30 years, Moneta can reduce Echo Bay Mine's share of the property from 50 percent to 20 percent. The Lik property is $12 \mathrm{mi}$ northwest of the Red Dog Mine, and has preliminary reserves of 18.2 million tons grading 10.2 percent zinc, 3.3 percent lead and $1.5 \mathrm{oz} /$ ton silver at a cut-off grade of 7 percent combined lead-zinc. An additional 10,000 to $15,000 \mathrm{ft}$ of drilling is reported to be necessary in the vicinity of a planned open-pit area, which contains an estimated two-thirds of the reserves to a depth of $500 \mathrm{ft}$.

About 500 tons of equipment and supplies valued at $\$ 3$ million were freighted cross-country from Coldfoot to Little Squaw Gold's Chandalar Camp by the lessee, Gold Dust Mines, Inc. Placer gold claims under evaluation at the camp cover more than $10 \mathrm{mi}$ of creek, and consist of 455 patented acres and 4,200 acres of state claims. Exploration and some production were reported on Tobin Creek, with future activity expected on Little Squaw and Big Squaw Creeks.

Some exploration activity including geochemical and geologi-

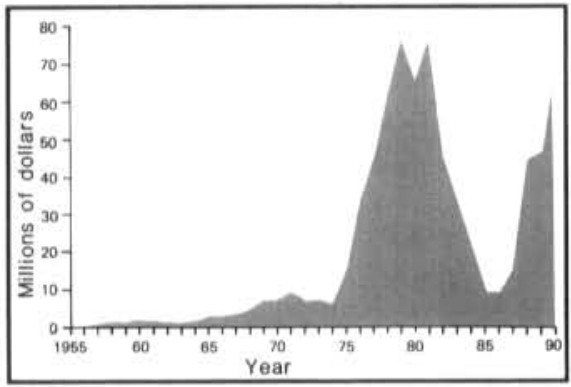

Figure 11. Mineral exploration expenditures in Alaska, 1956-90.

Table 5. Reported exploration expenditures and employment in Alaska by commodity and region, 1990

\begin{tabular}{|c|c|c|c|c|c|c|c|c|}
\hline \multirow{4}{*}{$\begin{array}{l}\text { Base metals } \\
\text { Precious metals }\end{array}$} & Northern & Western & $\begin{array}{l}\text { Eastern } \\
\text { interior }\end{array}$ & $\begin{array}{c}\text { South- } \\
\text { western }\end{array}$ & $\begin{array}{l}\text { South- } \\
\text { central }\end{array}$ & \multirow[t]{2}{*}{$\begin{array}{c}\text { Alaska } \\
\text { Peninsula }\end{array}$} & \multirow[t]{2}{*}{$\begin{array}{l}\text { South- } \\
\text { eastern } \\
\end{array}$} & \multirow[t]{2}{*}{ TOTAL } \\
\hline & \multicolumn{5}{|c|}{ Exploration Expenditures } & & & \\
\hline & $\$ 620,000$ & \$ 256,000 & $\$ 1,106,200$ & \$ 750,000 & \$ 765,000 & \$ 125,000 & $\$ 1,660,000$ & \$ $5,282,200$ \\
\hline & & & & & & & & \\
\hline Placer & 257,000 & $2,190,760$ & 312,000 & 110,000 & 418,150 & $\ldots$ & 41,484 & $3,329,394$ \\
\hline Lode & 250,000 & $5,385,000$ & $14,110,000$ & $1,277,000$ & $1,542,000$ & $1,575,000$ & $29,717,000$ & $53,856,000$ \\
\hline Coal and peat & .. & .. & 256,000 & .. & 65,000 & .. & . & 321,000 \\
\hline Industrial minerals & .. & .. & 20,000 & 2,000 & 63,000 & 70,000 & 215,000 & 370,000 \\
\hline Other & 25,000 & -. & 30,000 & 2,000 & 40,000 & .. & -. & 97,000 \\
\hline \multirow[t]{2}{*}{ TOTAL } & $\$ 1,152,000$ & $\$ 7,831,760$ & $\$ 15,834,200$ & $\$ 2,141,000$ & $\$ 2,893,150$ & $\$ 1,770,000$ & $\$ 31,633,484$ & $\$ 63,255,594$ \\
\hline & \multicolumn{8}{|c|}{ Exploration Employment } \\
\hline \multicolumn{9}{|l|}{ Employment } \\
\hline Workdays & 4,650 & 12,415 & 24,503 & 4,097 & 7,006 & 2,590 & 42,160 & 97,421 \\
\hline Workyears ${ }^{b}$ & 18 & 48 & 94 & 16 & 27 & 10 & 162 & 374 \\
\hline \multicolumn{9}{|c|}{ Number of companies } \\
\hline reporting ${ }^{e}$ & 9 & 15 & 34 & 10 & 23 & 4 & 14 & 109 \\
\hline \multicolumn{9}{|c|}{$\begin{array}{l}\text { - No expenditures reported. } \\
\text { ajade, platinum, diamonds, and colored gemstones. } \\
\text { 'Based on a 260-day workyear. } \\
\text { 'Some companies were active in several areas. }\end{array}$} \\
\hline
\end{tabular}




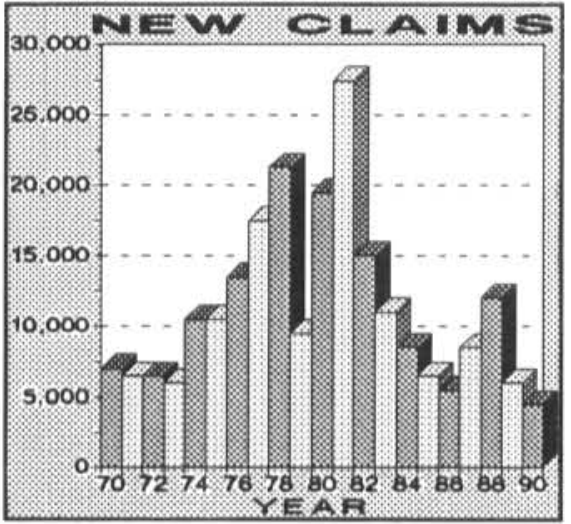

Figure 12. Number of new claims, 1970-90.

Figure 13. Claim assessment work filed, $1970-90$.
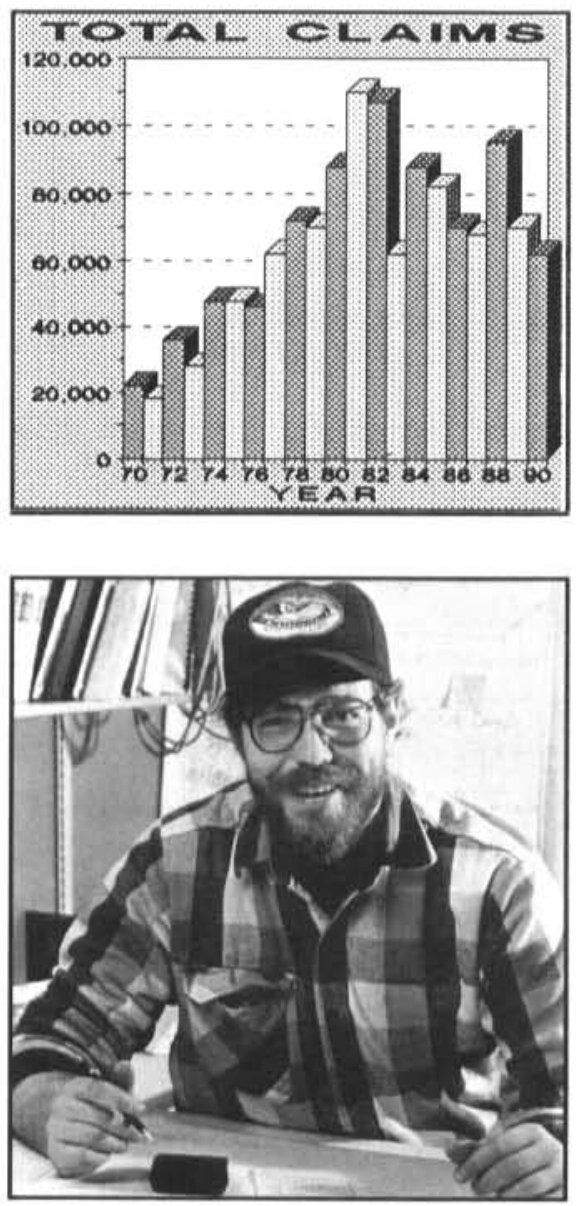

Figure 14. The science of advanced exploration of any mineral prospect involves highly trained technical specialists. Field data from core drilling and geophysical analyses are translated into maps which delineate the ore body. The timing of investment decisions often depends on the data generated during the summer field season. (Photo by Echo Bay) cal sampling, geophysical surveys and minor trenching was reported in Lake Creek and at the headwaters of Lake Creek and Spring Creek in the Wild River drainage. Paradise Valley Mining Company, Inc., also reported testing on Agnes and Oregon Creeks north of Bettles and west of Wiseman.

\section{Coal}

Arctic Slope Consulting Group continued to assess the feasibility of developing high quality bituminous coals on lands owned by Arctic Slope Regional Corporation. Between 1986-1990, 700 tons of coal were sampled or used domestically in 53 houses at Point Lay, Point Hope, and Wainwright. The company studied the feasibility of export of coal to Europe via a northern Russian transportation route.

\section{WESTERN REGION}

\section{Metals}

Exploration in the western region was predominantly for gold, both placer and hardrock. Nearly $\$ 8$ million was invested in 1990, compared with less than $\$ 4$ million in each of the last two reporting years.

As reported last year, Tenneco Minerals entered into a complex joint venture with Aspen Exploration and native interests to continue exploration at Rock Creek and on Anvil Creek north of Nome. Further drilling was done at the Rock Creek deposit where the inferred reserves are 6.6 million tons grading $0.07 \mathrm{oz} /$ ton. However, late in the year Tenneco announced their intention to withdraw from the joint-venture. A large soil geochemical program near Rock Creek defined a number of gold and arsenic anomalies in an 8-mi by 2mi zone, and one trench at Anvil Creek contained $110 \mathrm{ft}$ of $0.13 \mathrm{oz} /$ ton gold.
BHP-Utah International was actively exploring in the Bluff and Mt. Distin areas of the Seward Peninsula, including diamonddrilling and geochemical sampling.

Vinta Explorations, Ltd., acquired the Illinois Creek project from Goldmor Resources by purchase of all shares of the Silvertown Corporation, an Alaska company with the rights to explore and lease the property. The share purchase was worth $\$ 1,364,467$. During 1990 a $6,030 \mathrm{ft}$ drill program in 38 vertical reversecirculation drill holes confirmed proven and probable reserves of 1.59 million tons grading $0.072 \mathrm{oz} /$ ton gold and $1.79 \mathrm{oz} /$ ton silver, with an additional possible reserve of 0.76 million tons with $0.059 \mathrm{oz} /$ ton gold and $1.15 \mathrm{oz} /$ ton silver. The reserves were calculated by SAI, Inc., an affiliate of Salisbury Associates, Inc., of Spokane. These reserves occur within $1,900 \mathrm{ft}$ of a possible $3,200 \mathrm{ft}$ strike length of the known system, to a depth of only $250 \mathrm{ft}$. There are several other prospects within the 124,520 acre property, including Waterpump Creek 2 mi north of Illinois Creek. Preliminary geologic reserves at Waterpump Creek are 183,000 tons grading 16.1 percent lead, 5.5 percent zinc and $9.5 \mathrm{oz} /$ ton silver, based on $16,700 \mathrm{ft}$ of drilling in 38 holes completed by Anaconda.

Central Alaska Gold Company, as operator for the Nixon Fork Mining Company (Caithness Gold Mining, Ltd., Central Alaska Gold Company, and Battle Mountain Exploration Company), continued exploration of the gold-copper skarn mineralization at Nixon Fork, completing exploration drilling and trenching. A feasibility study will be completed in 1991 and a production decision will follow. The Nixon Fork copper-bismuth-gold deposit occurs in recrystallized Ordovician limestone adjacent to a Late Cretaceous monzonite pluton. The extensive drilling program in 1990 contributed largely to the increased exploration expenditures 
in the western region over those of the previous year.

Kennecott mapped $8 \mathrm{mi}^{2}$, took soil and rock geochemical samples and drilled two holes at Potato Mountain in a tin exploration program.

The Bering Straits Native Corporation conducted extensive reconnaissance exploration near Nome, Golovin, Solomon, Teller, White Mountain and Brevig Mission for gold and rare-earth elements. Most of these projects were joint ventures with local corporations or with federal agencies.

Berg and Wetlesen were actively exploring in the vicinity of the Independence Mine in the northeastern part of the Seward Peninsula, including geochemical and geophysical surveys and drilling. American Copper and Nickel Company ( $\mathrm{ACNC}$ ) was active in the Candle Hills area in a joint venture with Doyon Native Corporation.

Placer gold exploration in the western region attracted several companies. Alaska Placer Development, Inc., drilled and sampled Ophir Creek, and also drilled in a joint-venture with Bering Strait Native Corporation in the Solomon drainage.

Cyprus Gold, as lessee from Alaska Gold Company, excavated several test pits to check drillindicated grades on the Second Beachline and Monroeville Beachlines at Nome. Al Vezey drilled his property at Hastings Creek, near Nome, and BergWetlesen investigated Mud Creek, leased from Bud Meyers. Kougarok Mining Company stripped and prospected in the Kougarok River area.

Sphinx Mining, Inc., had an active exploration program south of Ruby on Greenstone, Midnight, Monument, and Trail Creeks, following up geologic mapping, geophysical and geochemical surveying with a substantial auger-drilling program. Flat Creek Mining Co.,
Inc., was also active in the same region, with a reverse-circulation drilling project on Flat and Timber Creeks.

\section{EASTERN INTERIOR REGION}

As in 1989, the eastern interior was the second most active area of Alaska for exploration in 1990, mainly due to advanced projects in the Fairbanks mining district, (see section on Advanced Exploration Projects). Placer mining camps in this region include Manley-ToftyEureka-Rampart, TolovanaLivengood, Fairbanks, Circle-Central, Richardson and 40-Mile-Eagle. There were active hardrock exploration programs in 1990 in most of these areas seeking the source or sources of the placer gold. Reported mineral exploration expenditures in 1990 were almost $\$ 16$ million, up 78 percent from the $\$ 9.17$ million reported in 1989 . A total of 24,503 man days of work were reported in 1990, equivalent to 94 year-round jobs.

\section{Metals}

The Fort Knox property of Fairbanks Gold, Inc., was the largest exploration project outside of southeast Alaska in 1990. Approximately 60 people were employed in an ambitious $\$ 9.32$ million program entailing $46,300 \mathrm{ft}$ of diamond drilling and $62,600 \mathrm{ft}$ of reverse-circulation drilling. A 170,000 ton bulk sample was reduced on site to 45 tons, of which 7 tons were split for metallurgical testing. Geotechnical work, environmental baseline studies and a prefeasibility study were also initiated in 1990. Further details of this project are available in the "Advanced Exploration Projects" section of this report (p. 15).

Central Alaska Gold Company, as operator for the joint venture with Caithness Gold Mining, Ltd., explored lands optioned from Doyon, Ltd. at the Flume Creek prospect, 25 mi northwest of Eagle, and completed diamond drilling, geochemical sampling, and geologic mapping. The company, also as operator for their joint venture with Caithness Gold Mining, Ltd., completed a second year of reconnaissance exploration on lands optioned from Doyon, Ltd. Work consisted of regional geochemical sampling and geologic mapping accompanied by exploration diamond drilling at one property.

$A C N C$, in a joint venture with Silverado Mines (U.S.), Inc., spent $\$ 1.6$ million drilling $17,434 \mathrm{ft}$ of core in the $\mathrm{O}^{\prime}$ Dea vein system at the Grant Mine, and on the subparallel Ethel vein system $2,000 \mathrm{ft}$ to the north. The results of this drilling show a resource of 212,000 drill-indicated tons grading $0.36 \mathrm{oz} /$ ton gold on a portion of the O'Dea system, which is still open at depth and along strike. In a separate joint-venture with Can-Ex Resources, ACNC mapped, sampled, and surveyed at Eagle Creek north of Fairbanks. ACNC contracted with Dighem Surveys \& Processing to fly an airborne geophysical survey, (magnetic and electromagnetic), over both properties.

Citigold Alaska, Inc., conducted an aggressive drilling and trenching program at the Ryan Lode property on Ester Dome, near Fairbanks. In the process, Citigold discovered a new vein system, the Curlew/lving, subparallel to the Ryan Lode, consisting of quartz veins within an altered monzodiorite intrusive host. This new system, which has not been explored laterally or to depth, could contain 350,000 tons of $0.077 \mathrm{oz} /$ ton gold to a depth of $100 \mathrm{ft}$. One particularly good hole in the Ryan structure assayed $4.25 \mathrm{oz} / \mathrm{ton}$ for more than $60 \mathrm{ft}$. Several 1,000 ft-deep holes on the shear confirm that the vein persists to depth and maintains width and grade.

Fairbanks Exploration, Inc., was also active in 1990, with projects 
ranging from precious metal exploration in Fairbanks, Livengood, and Central mining districts, to limestone north of Fairbanks and coal at Jarvis Creek near Delta. The exploration was conducted with jointventure partners ASARCO near Livengood, and with Freegold Recovery, inc., near Central. A bulk sample of the Christina Vein near Fairbanks was tested by Polar Mining, Inc.

Amax Gold Exploration, Inc., drilled Ed Montgomery's Ruth \& Lillian Creeks properties near Livengood, and had an active reconnaissance program throughout interior Alaska.

Many smaller exploration programs, almost all for precious metals, contributed significantly to the overall exploration expenditures. BHP-Utah had a regional reconnaissance program in the interior; Charles W. Cleveland, Lyle and Steve Collenge, Flat Pick Mining, Paul Manuel, Wilde Enterprises, Hecla Mining Company and Helen Warner all conducted exploration on their properties in the Circle district; in the 40-Mile district Tap the Pot Mining and Howard Fix were exploring for precious metals and stones. The Taurus porphyry copper-molybdenum deposit was restaked with 138 state claims which were acquired by Lodestar Explorations, Inc. when gold was found in old drill core. Tok Gold and Exploration reported activity near Tok. Grateful Dog Mining continued exploration for intrusive-hosted gold near Murphy Dome north of Fairbanks; Dennis Shepard and Mark Thoennes were active on Pedro Dome, Gypsy Luck, Inc., worked on the Bonnifield district, and Herning Exploration and Mining worked in the Upper Chena area.

\section{Coal}

Usibelli Coal Mine, Inc., had a large geophysics, drilling and bulk sampling program at Two Bull Ridge, North Fork Ridge, and Gold Run Pass near Healy. Fairbanks Exploration, Inc., in a joint-venture with Hobbs Industries, was actively exploring the Jarvis Creek coalfield near Delta. It was hoped that the 3 million ton proven reserve of subbituminous B coal in this field could provide the energy for a proposed backscatter radar at Tok and Glennallen.

\section{SOUTHCENTRAL REGION}

The southcentral region includes the Valdez Creek mining district, the Kennecott copper belt, and the copper and lode gold mineral belts from Valdez to Seward. A variety of metals and minerals have been developed and promising coal, gold, and base metal properties have been explored in recent years. Expenditures in 1990 increased 17 percent from 1989 levels of $\$ 2.44$ million to $\$ 2.9$ million.

\section{Metals}

CanAlaska Resources, Ltd., continued exploration in the Valdez Creek area on the Black Creek Adit, Gold Hill Zone, and TMC Zone of its Rainbow Hill Project. At the Black Creek Adit a 65-ft-thick granodioritic intrusive is emplaced in sheared agillite and graywacke. The intrusive and stockwork quartz veins within the intrusive both contain gold. A larger intrusive to the north is not intersected by the underground workings, but surface trenching showed gold in quartz stockwork veinlets within the intrusive. Work on the TMC Zone to the north of the intrusive in 1990, including some diamond drilling and $12,519 \mathrm{ft}$ of reverse-circulation drilling, identified five verticallystacked gold-bearing zones dipping to the south within a $700-\mathrm{ft}$ interval. The gold occurs in veinlets in both the igneous and sedimentary rocks. This zone was defined by geophysi- cal surveying over $5,000 \mathrm{ft}$, but only drill-intercepted over $2,600 \mathrm{ft}$. The zone is open to the west, and downdip where drill intercepts suggest greater width and better grades. Inferred reserves from the 1990 program are 262,000 tons with a grade of $0.151 \mathrm{oz} / \mathrm{ton}$ gold. Based on recent work and metal sieve analysis, these reserves have been increased to 383,000 tonnes grading $0.209 \mathrm{oz} /$ ton.

Caprock Corporation, leasing from Rowallen Mine Partnership was also active on White Creek in the Valdez Creek area, and a large reverse-circulation drill program on their placer claims was completed in 1990. Engineering and pit design in 1990 could result in production in 1991.

Gold Tech Resources, Inc., had an active year mapping, sampling, conducting geophysical surveys, opening old shafts and sinking new shafts in the Pass Creek and Valdez Creek area.

Hunt, Ware \& Proffett ran a significant diamond drill program on the Johnson River volcanogenic gold-zinc prospect in the southern Alaska Range. The property is leased by Howard Keck and partners from Cook Inlet Region, Inc., a Native corporation.

Ed Ellis continued mapping and sampling for gold in Tertiary sandstone on Lake Creek, a tributary to the Yentna River, and in the Willow Creek District Gold Cord Development Corporation continued exploration of its Hatcher Pass properties.

On the west side of the Susitna River, TC Mining mapped deposits in the Cache Creek and Thunder Creek drainages, and $\mathrm{H}$ \& $\mathrm{H}$ Exploration and Mining dug test-holes with a Nodwell-mounted backhoe on Forsy Gulch on Miller Creek.

IIS Company Machine, Inc., dug test-holes at Moose Pass on the Kenai Peninsula. Quartz Creek Exploration conducted geochemical and geophysical surveys in the same area. F.W. Haas Company 
sampled Canyon Creek at mile 50 on the Seward Highway using test pits and a suction dredge.

Hoffman Mining used a backhoe to dig test pits on the Middle Fork Mine in the Chistochina drainage. Mike Connor sampled Metal Creek in the Matanuska Valley using auger holes. Bob Ticheval used a backhoe to sample Busch Creek.

\section{Coal}

Hobbs Industries, Inc., had a significant exploration program at both the Evan Jones and the Castle Mountain coal mines near Palmer in the Matanuska Valley. At the Castle Mountain Mine the project included mapping, trenching, bulk sampling and drilling, while at the Evan Jones Mine in the Wishbone Hill coalfield a similar program included environmental base-line studies preparatory to development. Both projects are impacted by the Mental Health Lands dispute.

\section{Industrial Minerals}

Only a few of the many sand and gravel operations in the southcentral area did any exploration in 1990. AAA Valley Gravel, Inc., spent much of the summer evaluating the reserves along Wasilla Creek on Trunk Road at Palmer.

\section{SOUTHWESTERN REGION}

The southwestern region includes numerous lode and placer deposits originating in the Kuskokwim mineral belt, a 400-milong $(640 \mathrm{~km})$, northeast-trending zone of Late Cretaceous-early Tertiary metal-bearing volcanic and plutonic rocks. Mining districts include Goodnews Bay, Aniak, Iditarod, Innoko, Candle Creek, and lliamna. The region has produced about 10 percent of Alaska's gold (2.8 million oz; $87,092 \mathrm{~kg}$ ), nearly all of Alaska's platinum metals
$(575,000 \mathrm{oz} ; 17,885 \mathrm{~kg}$ refined), and all of Alaska's 41,000 flasks $(1,413,417 \mathrm{~kg})$ of mercury production. Mineral exploration expenditures reached $\$ 2.14$ million in 1990 , a 54 percent decrease from the $\$ 4.5$ million spent in 1989. Long dormant, southwestern Alaska has become one of the top areas of grassroots exploration efforts by recently arrived mining firms, most working on State of Alaska and Native corporation lands.

\section{Metals}

The most published prospect explored in the southwest region in 1990 was Cominco Alaska Exploration's Pebble Beach coppergold porphyry prospect about $20 \mathrm{mi}$ west of Newhalen on Lake Iliamna. Based on drill-holes 300 to $400 \mathrm{ft}$ deep and 1,000 ft apart, Cominco estimates a resource of 200 million tons of 0.4 percent copper and $0.012 \mathrm{oz} / \mathrm{ton}$ gold, and within that area a 50 million ton portion averages 0.5 percent copper and $0.015 \mathrm{oz} /$ ton gold. The deposit is still open at depth and to the northeast, so some increase is expected from the planned 1991 drill program (fig. 15).

Golden Horn Mining Company continued crosscutting near the Golden Horn shaft on Otter Creek near Flat, and a bulk sample was evaluated by Mountain States Engineering of Tucson, Arizona for separation. Minerals present include gold, scheelite, cinnabar, stibnite, silver, arsenopyrite and zircon.

Julian Creek Mining also worked near Flat on the George River, trenching and panning in an area where auriferous gravel is underlain by quartz porphyry. Battle Mountain Exploration Company had a core-drilling program at the Independence Mine between Ganes and Yankee Creeks in the Ophir mining district, and also on Granite Creek, a tributary to

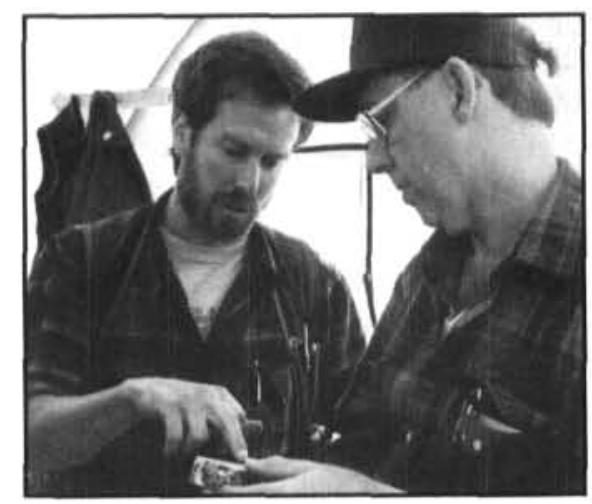

Figure 15. The Pebble Beach Project ore reserves are estimated at 200 million tons, based on the findings of the 1990 drilling season. A project geologist at the Cominco Alaska Exploration site shows a core sample containing disseminated copper sulfide minerals to Sam Dunaway (right), Director of the Alaska Division of Mining. (Photo by Cindy Roberts)

the George River in the central Iditarod Quadrangle. The mineralization in the area appears to be structurally controlled quartz-stibnitegold veins associated with quartzporphyry intrusives. Battle Mountain leased the Independence Mine ground from Lloyd Magnuson and the Granite Creek prospect from L.E. Wyrick.

Richard Wilmarth continued placer sampling of Chicken Creek in the Iditarod area with a backhoe. James Wylie spent some time mapping in the Sleetmute Quadrangle. Howard N. Bowman followed up a magnetometer survey on Portage Creek at Lake Clark with test pitting. John B. Murphy prospected in the Middle Kuskokwim region.

\section{Industrial Minerals}

The city of Anvik prospected for gravel at the Anvik gravel pit, in preparation for a water-treatment plant.

\section{ALASKA PENINSULA}

The Alaska Peninsula region includes the Tertiary plutonic- 
volcanic rocks of the Alaska-Aleutian arc and recent Quaternary volcanoes of the Aleutian Chain. Mineral exploration during 1990 in this classic epithermal gold setting amounted to $\$ 1.77$ million compared to $\$ 2.01$ million in 1989 , a decrease of 12 percent.

\section{Metals}

Battle Mountain Exploration Company had an aggressive precious metal exploration program in 1990 on lands leased from the Aleut Native corporation on Unga, Popof, and Nagai Islands in the Shumagins. The program included mapping, rock sampling and drilling following a large airborne magnetic/electromagnetic geophysical survey. A smaller geophysical survey was also conducted on Umnak and Unalaska Islands, followed by intensive geologic mapping, geochemical sampling and drilling.

There was no exploration in 1990 by Alaska Apollo Gold Mines, Ltd., on its Shumagin and Apollo ore deposits where reserves stand at 208,260 tons grading $0.765 \mathrm{oz} /$ ton gold and 2.47 oz per ton silver, but work was done to ready the property for production.

\section{Industrial Minerals}

Moorcroft Construction Company spent part of the 1990 season investigating sources of gravel for the Naknek-King Salmon Highway.

\section{SOUTHEASTERN REGION}

The Panhandle of Alaska received the largest exploration effort of any area of the state, accounting for $\$ 31.6$ million in expenditures, about half of the statewide total. Mineral deposits under investigation include vein, vein disseminated, massive sulfide, and skarn types.

\section{Metals}

Kennecott's Greens Creek Mining Company, a wholly owned subsidiary of the RTZ Group, contracted with Nana-Coates drilling for $21,721 \mathrm{ft}$ of diamond drilling from the surface at the Big Sore Claims at the Greens Creek Mine. Surface mapping and geochemistry complemented the drill program. Kennecott also had a substantial program mapping and sampling the rest of the claim holdings nearby, including the Mariposite group.

Echo Bay Exploration, Inc., had the largest exploration program in the state in 1990 in four separate projects, the A-J, the Treadwell, the Kensington and the Herbert Glacier. The A-J/Treadwell and the Kensington are both advanced exploration projects, and are discussed in more detail in that section of this report. About $83,000 \mathrm{ft}$ of diamond drilling at the A-I Mine was supplemented by driving of drifts, ramps and crosscuts which were mapped and channel-sampled. This project and the associated Treadwell, where $10,000 \mathrm{ft}$ of diamond drilling was completed in 1990, are a jointventure with Watts, Griffis, McQuat, Ltd., (WGM) carrying 15 percent. Tonto Drilling Services was the contractor for the Treadwell, while Boyles Brothers Drilling Company and Nana-Coates Diamond Drilling, Inc., did the drilling at the A-J Mine.

The Draft Environmental Impact Statement for the A-J Mine was issued early in 1991, and the stated reserves are 63.6 million tons of proven and probable ore grading $0.052 \mathrm{oz} /$ ton gold and 42.1 million tons of possible ore grading $0.051 \mathrm{oz} / \mathrm{ton}$.

Fifty miles north of the A-J Mine at Juneau, Echo Bay in a 50 percent joint venture with Coeur Alaska, Inc., contacted with Wink Brothers Diamond Drilling, Inc., and Nana-Coates for $122,000 \mathrm{ft}$ of underground diamond drilling at the Kensington Mine. This was complemented by driving crosscuts, drifts, ramps, and raises. Ore reserves were increased in 1990 to 12.8 million tons grading $0.148 \mathrm{oz} /$ ton gold. Late in the year it was announced that each partner will invest $\$ 30$ million for mine development pending approval of the final environmental impact statement.

Another advanced exploration project adjacent to the Kensington is the Jualin Mine, where Placer Dome (U.S.), Inc., is currently earning a 50 percent interest from International Curator Resources (60 percent) and Granges, Inc., (40 percent). About $26,000 \mathrm{ft}$ of diamond drilling in 1990 resulted in estimates of the resource as 1.07 million tons at an uncut grade of $0.349 \mathrm{oz} /$ ton gold. More details are provided in the "Advanced Exploration" section of this report. Placer Dome also drilled about $3,000 \mathrm{ft}$ on the Dream massive sulphide deposit, and had several reconnaissance projects throughout southeast Alaska.

Hecla Mining Company had a substantial core-drilling program at its Yakima, Red Diamond, and Lawson Creek properties on Douglas Island in the Juneau Gold Belt.

Pulsar Resources (U.S.), Inc., a wholly owned subsidiary of Hyder Gold, Inc., had a large regional geologic and geochemical program in the Hyder district in the extreme southeast of the state, and contracted for 5,500 ft of core drilling.

Lac Minerals (USA), Inc., jointventuring with Noranda Exploration, Inc., had an active exploration season, focussed on the Niblack, Ruby Tuesday, and Kaigani base and precious metal prospects.

Sealaska Corporation, a regional Alaska Native corporation, initiated exploration on the following locations in 1990: North of Klawock where significant gold mineralization may be associated with a buried porphyry; at Coco 
Harbor where skarn copper may have gold potential; in Hetta Inlet and the Trocadero Bay area where volcanogenic massive sulfides contain precious metal credits; at Dora Bay and Sukkwan Island where rare elements have been confirmed. At Breezy Bay on Dall Island, Sealaska identified a large volume of chemical-grade limestone containing more than 98 percent calcium carbonate. The company leased a mineral property on Prince of Wales Island to American Copper and Nickel, Inc. (fig. 16).

Hyak Mining Company, which holds a 5 percent interest in the Jualin project, had active exploration projects consisting of mapping, geophysical surveys, and geochemical sampling on Chichagof Island. Hecla Mining Company drilled on the Red Diamond prospect, under lease from Hyak, at the south end of Douglas Island. BHP-Utah spent a month on Prince of Wales Island sampling and mapping in a reconnaissance program for base and precious metals. Delta Minerals had a significant reverse circulation drilling program, and mapped, sampled and conducted geophysical surveys in the Porcupine Townsite near Haines, and Snowlion Mining Company dug a number of prospect holes in the same area.

Guy Comer of Ketchikan explored the Lucky Nell vein gold mine on Prince of Wales Island. His work at the mine consisted of reopening the sloughed portal along with dump and underground sampling for metallurgical testing. The Lucky Nell had minor gold production in the 1930 s and early 1940s.

Various individuals also conducted assessment work on vein gold deposits in the Hollis area of Prince of Wales Island.

\section{ADVANCED EXPLORATION PROJECTS}

\section{Fort Knox}

The Fort Knox gold property, located about $15 \mathrm{mi}$ northeast of

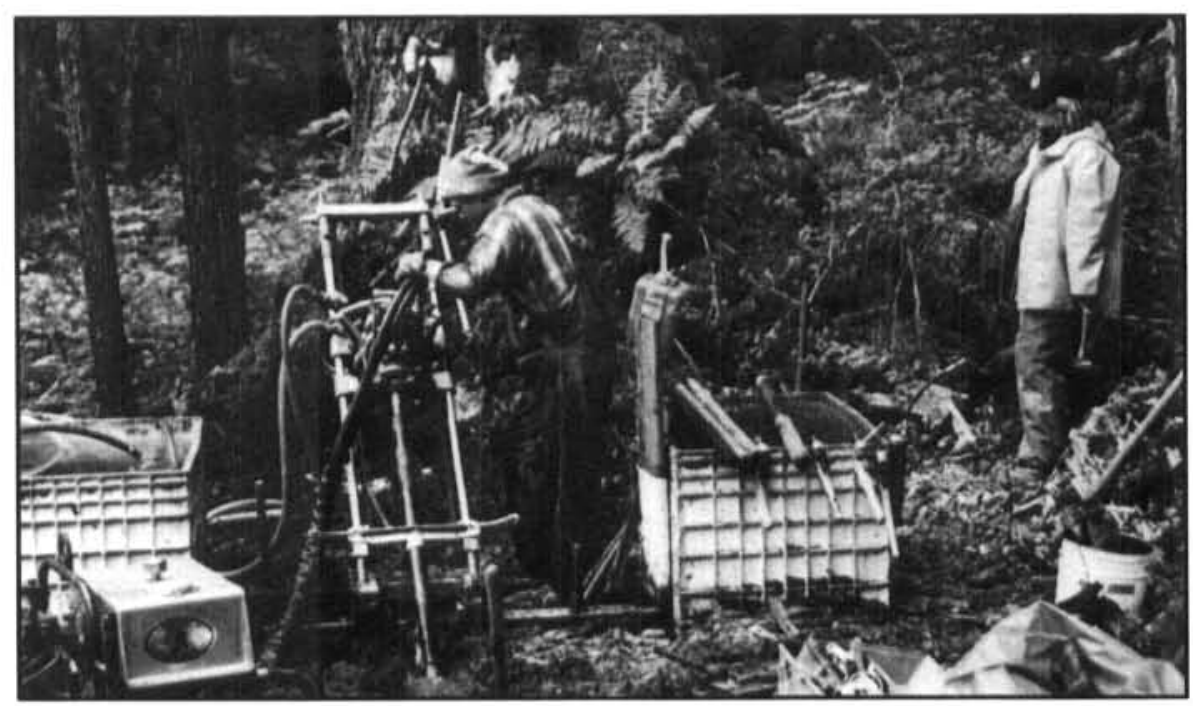

Figure 16. In the rain forest of southeast Alaska, there is considerable exploration activity. American Copper and Nickel Company utilizes a Wink drill rig on a prospect on Prince of Wales Island. The exploration "footprint" in the heavy forest is nearly invisible. (Photo by T.K. Bundtzen)

Fairbanks, is 51 percent owned by Fairbanks Gold, Ltd., with the remainder held by Ventures Trident II Limited Partnership of Lakewood, Colorado, and Bob Nye. Gold occurs in several generations of quartz veins and veinlets within a broad northwesterly-trending zone crosscutting a Cretaceous granodiorite/quartz monzonite stock. Associated trace minerals include molybdenite, bismuthinite, scheelite, and pyrite. Preliminary tests by Lakefield Metallurgical Lab. in Ontario, Canada, indicate that 95 percent to 97 percent recovery is possible using 0.46 to 0.68 pounds cyanide per ton. Strathcona Mineral Services supervised excavation of a 45,000-ton bulk sample from a 170,000-ton pit in 1990.

Strathcona is conducting bulk sample assays for cyanide leaching of the material. Davy McKee Corporation has been selected as contractor for the prefeasibility study, and new reserve figures are expected by May 1991.

Earlier company press releases indicated that the deposit contains between 4.74 and 6.04 million oz of gold contained in 99- to 195million tons of rock, depending on the cut-off grade. This was based on $160,000 \mathrm{ft}$ of reverse-circulation drilling and $30,000 \mathrm{ft}$ of diamond drilling (fig. 17). In situ gold grades are reported to be between $0.031 \mathrm{oz} /$ ton and $0.048 \mathrm{oz} /$ ton, at cut-off grades of 0.01 to $0.02 \mathrm{oz} /$ ton. Mining costs are estimated to be 15 to 20 percent higher than in Nevada.

The Fairbanks Mining District, covering about $800 \mathrm{mi}^{2}$, produced about 8-million oz of gold, of which only about 300,000 oz were from hardrock mines. This provides a perspective on the importance of the Fort Knox deposit, should it be developed.

\section{Kensington}

Jointly owned by Coeur Alaska and Echo Bay Alaska, Inc., the Kensington project is located on the east shore of Lynn Canal, about 50 mi north of Juneau. Recent press releases place reserves at 12.8 million tons containing 1.9 million oz of gold, mainly as the telluride calaverite (AuTe${ }_{2}$ ) with minor native gold. Recovery at a mining rate of 4,000 tons/day, or 


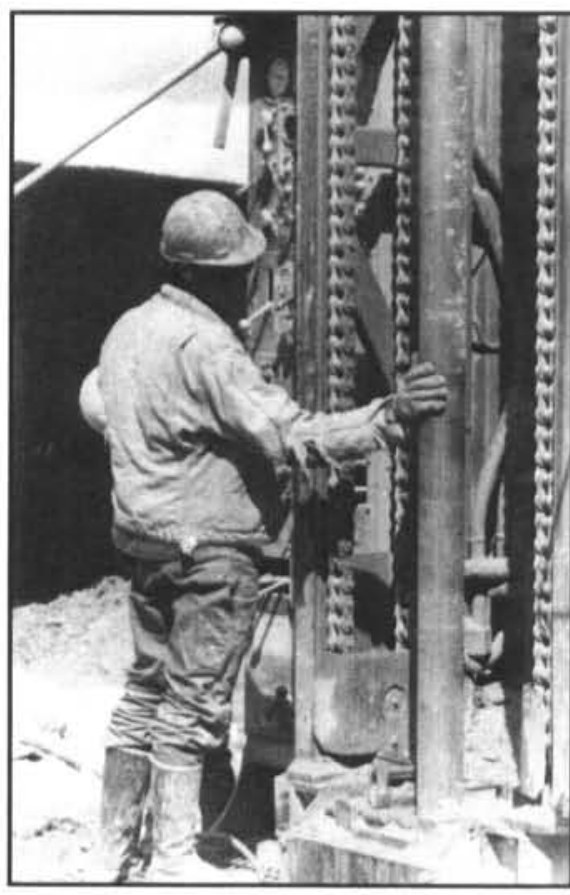

Figure 17. In interior Alaska, Fairbanks Gold Inc. completed a prefeasibility study for the Fort Knox Project. Based upon favorable results, the project has entered the permitting phase and is drilling for ore reserve definition. The feasibility study will be completed by the end of 1991. The company predicts an annual production of about 300,000 oz of gold if development occurs. (Photo by Aisha Tinker)
$200,000 \mathrm{oz}$ of gold per year, is believed to exceed 92 percent based on metallurgical tests. If the mine goes into production, it will employ about 350 people (fig. 18).

Gold is found in a complex vein stockwork, dated at 55 million years (Goldfarb and others, 1991), in older Jualin diorite, dated at 105 million years (Gehrels, 1991). This formation has an average north-south trend and $65^{\circ}$ east dip. The system, which is open to the south and at depth, is more than $1,500 \mathrm{ft}$ long and 2,800 ft deep, and has an average width of about $50 \mathrm{ft}$. Individual veins are from one inch to several feet wide, and are often enclosed in zones of potassic alteration enclosed within broader zones of widespread propylitic alteration. Pyrite and rare chalcopyrite are associated with the gold.

A 5,200-ft adit at the $800 \mathrm{ft}$ level provides access to the Kensington vein stockwork, and a raise joins this level with a $4,800 \mathrm{ft}$ long adit at the 2,050 $\mathrm{ft}$ elevation which was driven in 1915 through the Kensington to access another

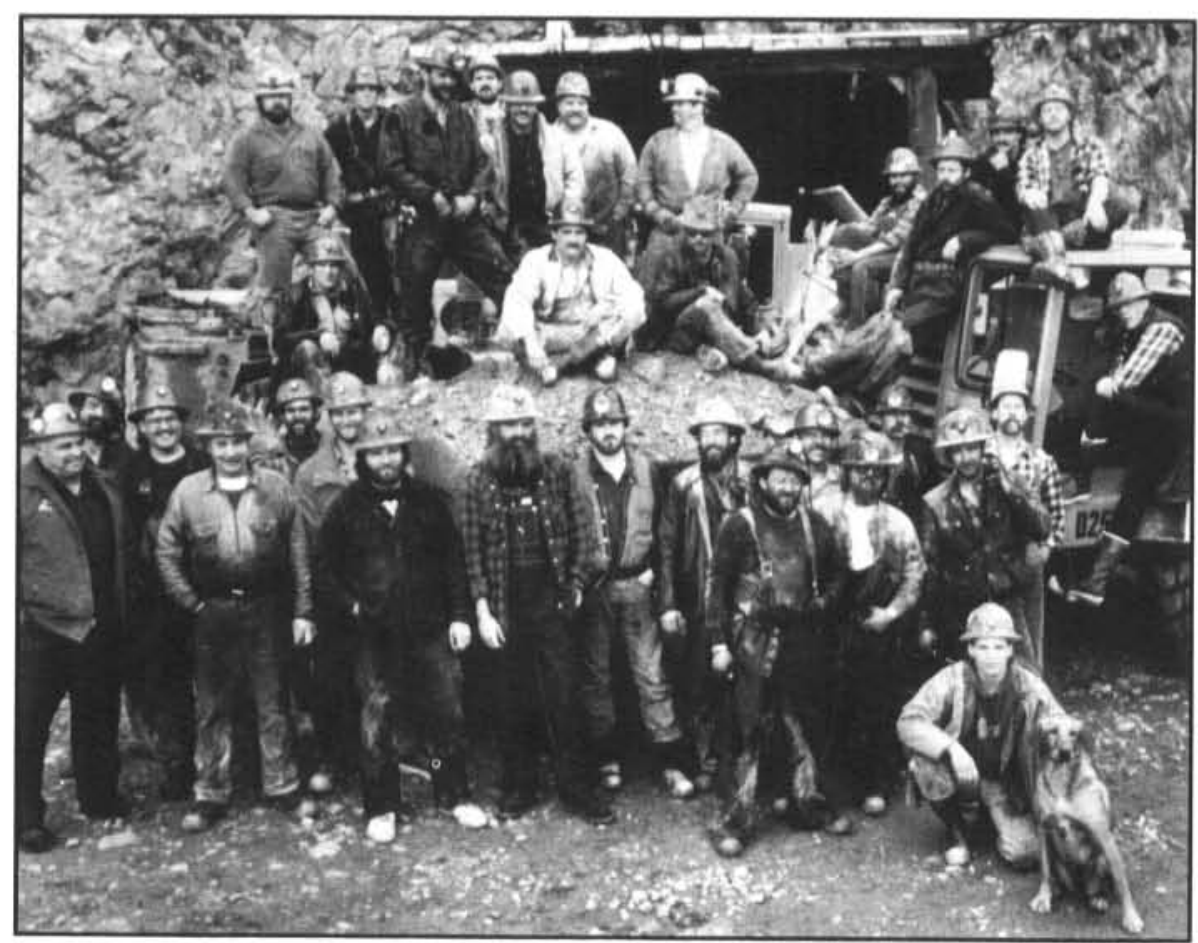

vein to the east. A ramp from the $850 \mathrm{ft}$ level provides access to the footwall of the Kensington at the $900 \mathrm{ft}$ and $1,175 \mathrm{ft}$ levels.

The rock in the proposed mine area is extremely competent, and has required only 1,000 rock bolts in over $11,000 \mathrm{ft}$ of tunnel. This characteristic should allow modified longhole open stoping methods using both transverse and longitudinal stopes depending on the width of the stockwork system.

\section{Jualin}

Placer Dome U.S. is currently earning a 50 percent share in this property from International Curator, (60 percent) and Granges, Inc., (40 percent) who optioned it with a 5 percent royalty from Hyak Mining Co., a Juneau-based company. In mid-1990, 100 drill holes totaling $73,000 \mathrm{ft}$ had been drilled in the Main Zone to indicate a resource of 1.04 million tons at $0.28 \mathrm{oz} /$ ton. By November 1990, a total of 1.07 million tons at an uncut grade of $0.349 \mathrm{oz} /$ ton was reported, without consideration of mining or metallurgical constraints.

Like the Kensington deposit only a few miles to the northwest, the Jualin is hosted in the multiphase Jualin diorite, which has compositions ranging from diorite to quartz monzonite. About 20 percent of the pluton is sheared, and the brittle fractures in the homogeneous rock between the shears appears to be a control of mineralization.

Alteration is complex, with ubiquitous propylitic alteration

Figure 18. This Kensington Mine crew and others like it are having a major impact on the state's overall employment figures, especially in the Juneau area. Although mining remains a small component of the area's total employment, there has been a 700 percent increase since 1985. (Photo by Echo Bay) 
events overprinting an earlier, pervasive, potassic event. These alteration events precede the main mineralization, which is of three types. Stockwork gold vein zones with quartz, carbonate, pyrite, galena and sphalerite are up to $50 \mathrm{ft}$ wide and contain the bulk of the estimated tonnage. More massive and restricted veins, usually 1 to $5 \mathrm{ft}$ wide, contain abundant gold and sulfides, and often crosscut the earlier carbonate-rich veins, significantly enriching their potential. A third, and only recently recognized, target is quartzsericite-pyrite-sphalerite-gold related to late-stage felsic dikes which crosscut the Jualin diorite.

\section{A-J and Treadwell Mines}

Echo Bay Alaska, Inc., (85 percent) and WGM, Inc., (15 percent) continued intensive exploration of the Alaska-Juneau (A-J) Mine beneath Roberts and Gastineau Peaks immediately behind Juneau. The A-J and Perseverance Mines produced 3.3 million oz of gold from 99 million tons of rock averaging $0.042 \mathrm{oz} /$ ton during the period 1901-1943, and at peak production mined 13,000 tons/day. Present plans call for mining about 22,500 tons/day with a work force of about 450 (fig. 19).

The A-J orebody is about $3 \mathrm{mi}$ long, trending northwesterly and dipping about $65^{\circ}$ to the northeast. Like the Kensington and Jualin deposits $50 \mathrm{mi}$ to the north, the A-J is localized along the Coast Range Megalineament. But instead of occurring in diorite, the A-J deposit occurs as vein swarms near the contact between a footwall greenschist and hanging-wall metagabbro with black phyllite. Veins range from $1 \mathrm{in}$. to $15 \mathrm{ft}$, and average about 6 in. with average grades of about $0.5 \mathrm{oz} /$ ton. Mineralization occurs from 2,500 ft above sea level to at least $1,300 \mathrm{ft}$ below sea level, and is accessed by tunnels and declines from the Sheep Creek Valley about 4 mi east of Juneau. A major east-west fault, the Silverbow, with $1,800 \mathrm{ft}$ of oblique left-lateral displacement, bisects the orebody near a hoist and internal shaft which extends $1,000 \mathrm{ft}$ below sea level.

At the north end of the North orebody veins are hosted in metagabbro with a slate hanging wall, and vein density is sufficient to average $0.10 \mathrm{oz} /$ ton over $135 \mathrm{ft}$. Pyrrhotite is the most common associated sulphide, with lesser amounts of sphalerite and minor galena. In the middle of the South orebody, about a mile southeast of the Silverbow Fault, mineralization in the metagabbro footwall zone averages $0.037 \mathrm{oz} /$ ton over $450 \mathrm{ft}$. In the same crosscut into the hanging wall phyllites and metagraywacke, another swarm of veins adds at least $\mathbf{2 5 0}$ more feet of mineralization for an aggregate width of $700 \mathrm{ft}$. Mineralization extends over $350 \mathrm{ft}$ beyond the crosscut. This crosscut demonstrates the presence of ore veins in both the hanging wall and footwall rocks adjacent to the main northwest-southeast fault. Galena is more common in the south orebody, which probably accounts for the higher silver content of the ore.

About 2-1/2 mi southwest of the A-J orebody, and about $1 \mathrm{mi}$ across the Gastineau Channel from the Echo Bay exploration office at Thane, the Treadwell deposit trends subparellel to the $\mathbf{A}-\mathbf{J}$, with a similar steep southeasterly dip. The deposit was worked to $2,300 \mathrm{ft}$ below sea level, and exploratory work had been done at the $2,800 \mathrm{ft}$ level when a massive collapse and inflow of water flooded the mine on April 20-21, 1917.

The Treadwell operated from 1891 to the time of the cave-in, mining 15.2 million tons of rock

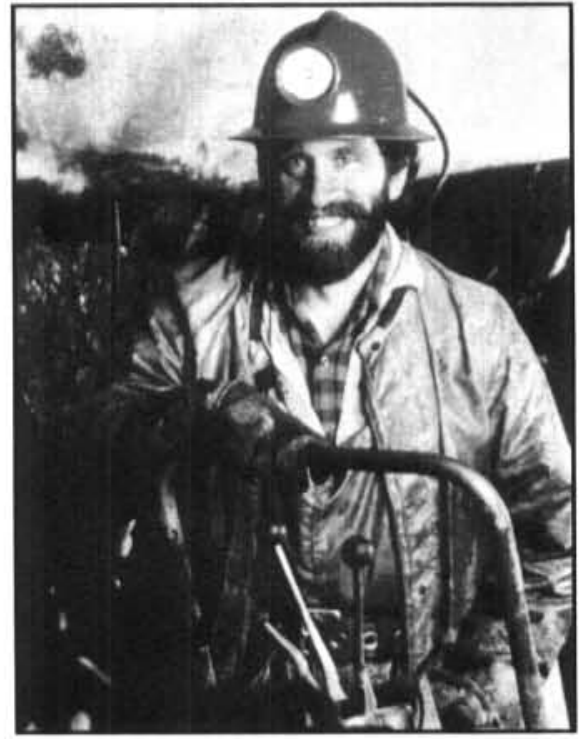

Figure 19. Efforts to reopen the A-J mine in the city of Juneau depend on the economic picture as well as a number of other factors. Here, a miner operates a core-drill at an underground exploration station. More than \$25 million was spent on just three advanced exploration projects in southeast Alaska during 1990. (Photo by Echo Bay)

with an average grade of $0.12 \mathrm{oz} /$ ton at a gold price of $\$ 20.67$ per ounce. Through 1922, the Alaska United Company and the Alaska Mexican Company mined a further 12.2 million tons with an average grade of about $0.114 \mathrm{oz} /$ ton from adjacent properties.

In 1990 Echo Bay Mines, Inc., drilled a 5,000-ft hole from the east side of the Gastineau Channel to intersect the Treadwell structure on the west side of the channel. (This project is discussed further in the Drilling Activity section, p. 40.) The best mineralization was a true width of $187 \mathrm{ft}$ of $0.101 \mathrm{oz} /$ ton gold, including $49 \mathrm{ft}$ with $0.223 \mathrm{ozl}$ ton. This interception at $3,250 \mathrm{ft}$ below sea-level was in the downrake extension of the diorite lobe below the Mexican Mine. It is possible that the deep levels of the Treadwell could be accessed by declines under the channel from the internal shaft of the A-J Mine. 


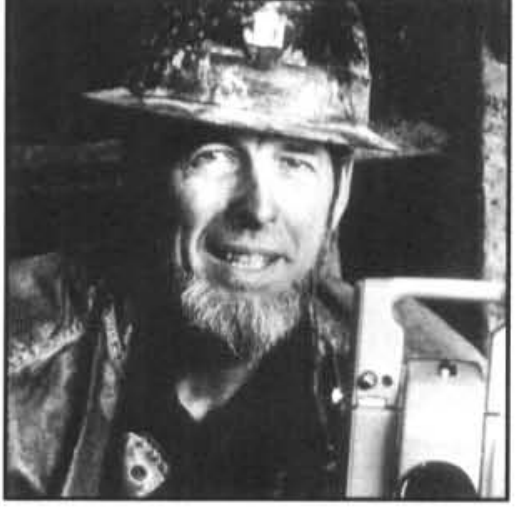

Echo Bay

\section{DEVELOPMENT}

\section{A dramatic 90 percent decrease in mineral development expendi- tures in the state in 1990 reflects the Red Dog Mine transition from development to production.}

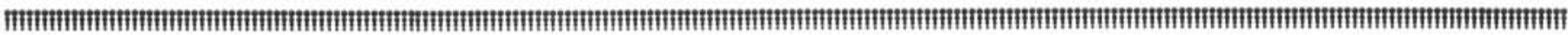

\section{INTRODUCTION}

The decline in mineral development expenditures noted in 1989 continued in 1990, when only $\$ 14.3$ million was reported (table 6). Several projects in the state could progress to a development stage in the next few years; this would boost present low development expenditures. Of this $\$ 14.3$ million, $\$ 3.1$ million was expended on coal development, $\$ 4.1$ million on base metal development, and $\$ 7.1$ million on development of gold deposits.

Only expenditures after a production decision has been made are considered as development expenditures, but in placer mining some development activities such as stripping or thawfield drilling are reported as production expenses. In general, only the expenditures identified by the respondents as development are included in this section.

As in the past annual reports the selected development projects are considered in relation to the

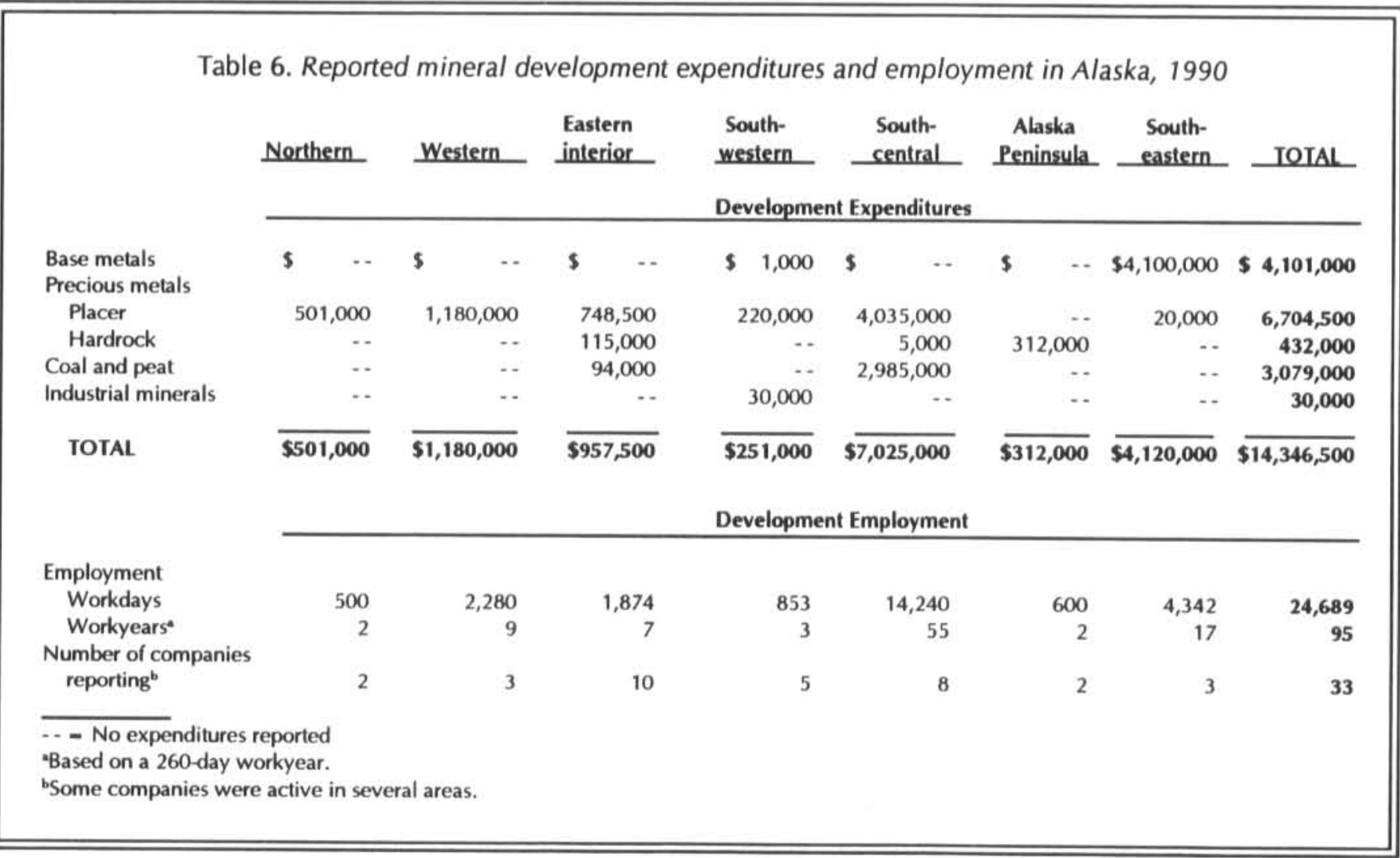


seven geographical divisions of the state shown in figure 20 .

\section{PRECIOUS METALS}

About 50 percent of the 1990 development money was spent on precious metal projects. Of this $\$ 7.1$ million, 94 percent was invested in placer rather than hardrock projects.

The largest project was that of Cambior Alaska, Inc., in southcentral Alaska at the Valdez Creek placer project, where total reserves-proven, probable and possible-as of December 31, 1990, stand at 5,005,000 $\mathrm{yd}^{3}$ with an overall grade of about $0.10 \mathrm{oz}$ of refined gold per cubic yard. As its major work Cambior constructed a diversion dike and excavated a new, 5,200-ft long channel for Valdez Creek along the base of the right limit hillside. The diversion was necessary because the original mining excavation had proceeded up-valley as far as possible without intercepting the creek.

During 1990 Cambior acquired a 28.125 percent interest in the Valdez Creek placer from American Barrick Resource Corporation for $\$ 3.64$ million, and now owns 49 percent of the project. By agreement with Camindex Resources, Inc., which owns the remaining 51 percent, Cambior Alaska, Inc., will act as operator. In addition to diversion of the creek, a new wash plant and tailings pond were designed and constructed in 1990, which should allow 60 percent more throughput than the previous system.

Alaska Gold Company had a large thawfield drilling project at Nome in western Alaska in preparation for mining by dredges No. 5 and 6. Although the thawfield program was not as extensive as in the previous two years, the reason is that some of the ground which the company proposes to mine is already thawed, and does not require as much preparation.

In northern Alaska, Mick Manns reported significant development of Flat, Agnes, and Oregon Creeks, mainly in stripping of frozen overburden. Twenty-one other placer operators in the eastern interior, southwestern, and southcentral Alaska reported similar development activity.

Fewer companies reported development of hardrock precious metal properties, but in interior Alaska, Polar Mining bulk sampled and tested material from the Christina Vein at Cleary near Fairbanks. On Unga Island in the Alaska Peninsula area Alaska Apollo Gold Mines, Ltd., had a substantial program to enlarge and update its camp at the Shumagin Project to accommodate 25 workers. The development work also included engineering design work for two haulage adits and a connecting shaft to intersect the orebody which is estimated to contain 208,260 tons grading $0.765 \mathrm{oz} /$ ton gold and $2.47 \mathrm{oz} /$ ton silver.

\section{BASE METALS}

The only significant base metal development project in 1990 was at the Greens Creek Mine of Kennecott's Greens Creek Mining Company. With partners Hecla Mining Company, CSX Alaska Mining, Inc., and Exalas Resources, over $60,000 \mathrm{ft}$ of drilling was completed from underground cross-cuts to test the extension of known reserves on the gold- and silver-rich lead-zinc-copper deposit near Juneau in southeast Alaska (fig. 21). Results of other work have added an additional 14 million tons of reserves in all categories to the mine.

Figure 20. Selected mineral development projects.

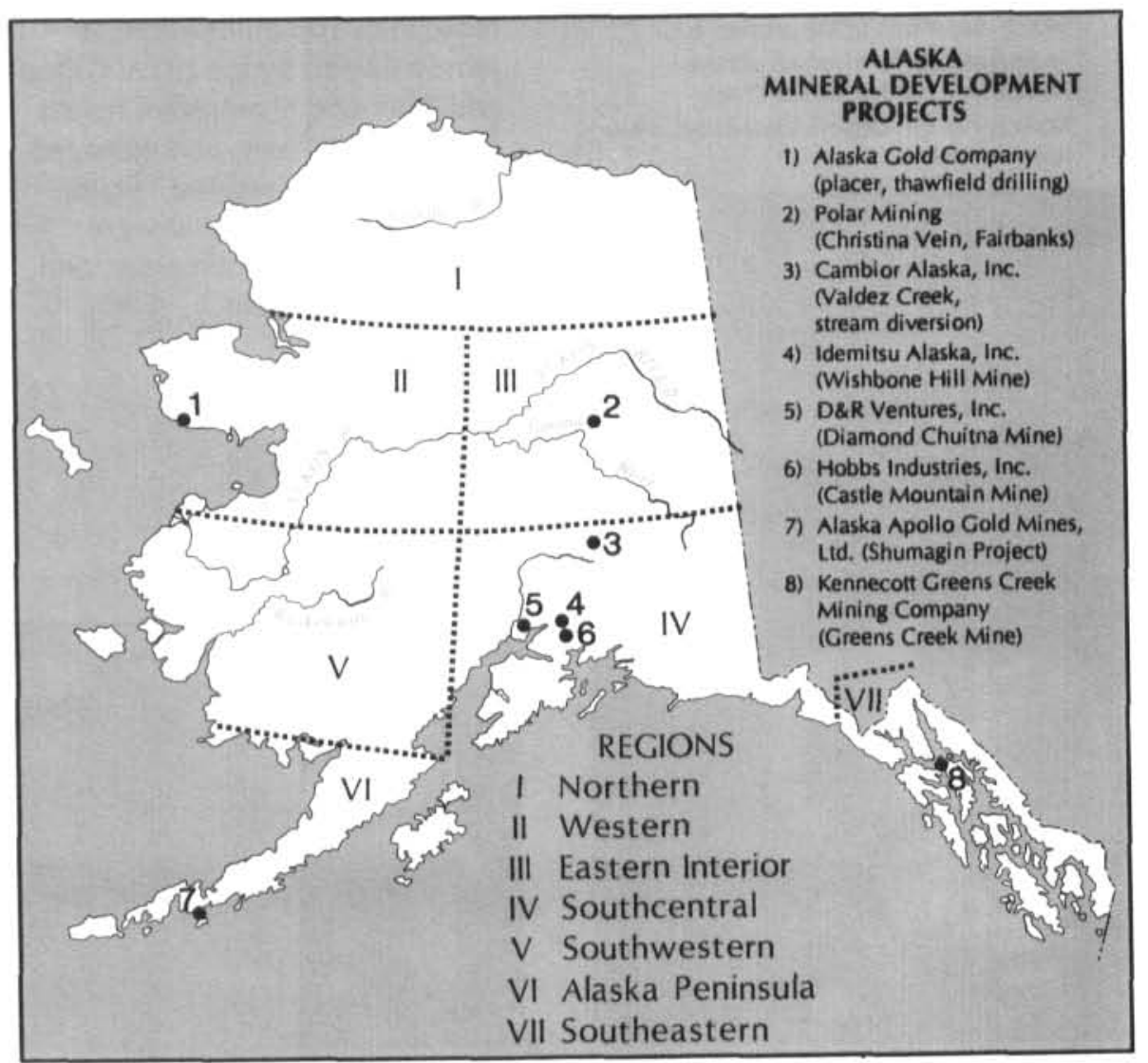




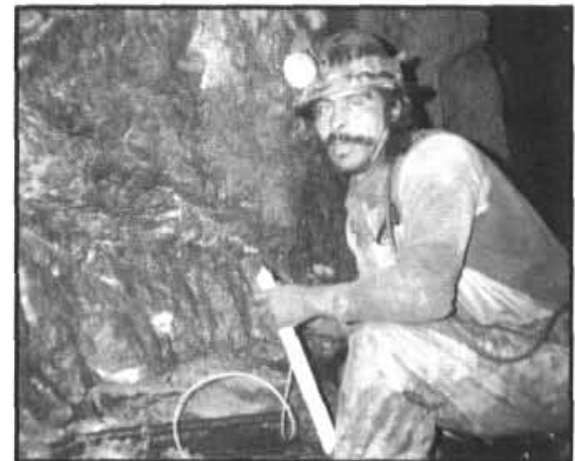

Figure 21. For the second year Greens Creek Mine on Admiralty Island in southeast Alaska was the largest producer of silver in the United States. The mine is located in the Tongass National Forest and is a model of environmentally sound operations. Here, a blaster loads water gel to loosen rock at the production face. (Photo by /ohn Barry

Figure 22. Hydrologists from DCCS have done extensive research over the last four years, documenting the erosion and sedimentation level which occurs naturally in the Hoseanna Creek drainage at the Usibelli Coal Mine. (Photo by Bruce Campbell)

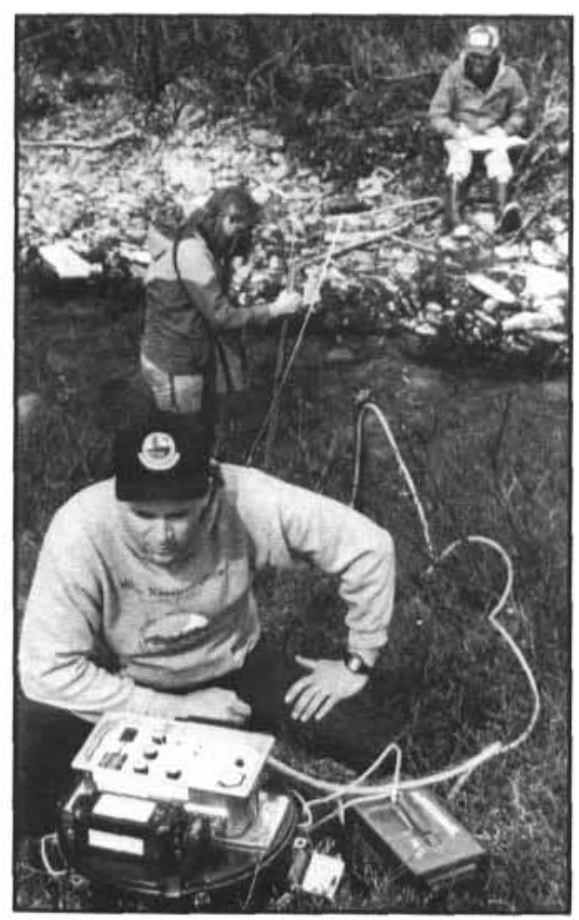

COAL

In mid 1990 a court injunction halted mineral development on lands in Alaska that are to be managed by the Mental Health Lands Trust. Although production was halted at Wishbone Hill Mine near Palmer, activity in 1990 included core and churn drilling, geophysical logging, detailed mine engineering and engineering design of facilities, permit preparation, and environmental baseline studies.

Idemitsu Alaska, Inc., the developer of the project, estimates the mine contains 15-million tons of high-heat content, low-sulfur coal. It is expected to be active for 15 years and provide approximately 200 jobs with an annual payroll of more than $\$ 10$ million.

Another southcentral Alaska coal project that had a substantial development program in 1990 was the Diamond Chuitna Mine in the Beluga coal fields. This project of more than $\mathbf{3 0 0}$ million tons is jointly owned by the BHW Group and Diamond Shamrock Chuitna Coal Joint Venture, and managed by D \& R Ventures, Inc. Major efforts reported in 1990 were engineering, environmental, and permitting activities.

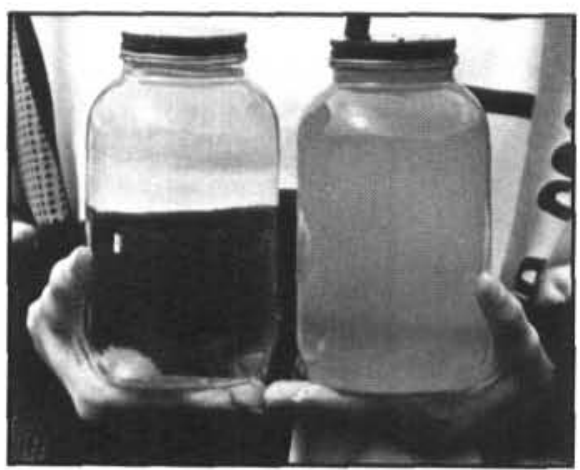

Hobbs Industries, Inc., did surface excavation and development of the portal at its Castle Mountain Mine near Sutton. In 1990 the company built surfaceplant facilities, such as settling ponds, access roads, working pads, and storage areas. According to Hobbs, reserves at this mine are estimated at about 22.4 million tons. Only 2 million tons of the reserves are on lands unaffected by the Mental Health Land issue, Castle Mountain Mine produced about 6 million tons of coal between 1920 and 1968, which Hobbs plans to sell locally as well as overseas.

As in past years, Usibelli Coal Mine, Inc., had a significant development program at the Usibelli Coal Mine near Healy in interior Alaska. Specific activity was drilling and hydrology testing in the Hoseanna Creek drainage (figs. 22 and 23).

\section{INDUSTRIAL MINERALS}

With few major construction projects statewide in 1990 there was a corresponding decline in development of rock, sand and gravel resources. Only $\$ 30,000$ of development was reported, down substantially from the $\$ 7$ million reported in 1989.
Figure 23. On August 26, 1989, samples were taken from the naturally turbid waters of Hoseanna Creek (right jar) and the clear discharge from the Usibelli settling pond (left jar). Usibelli Coal Mine made a major investment to bring discharged water to this required standard. (Photo by Usibelli) 


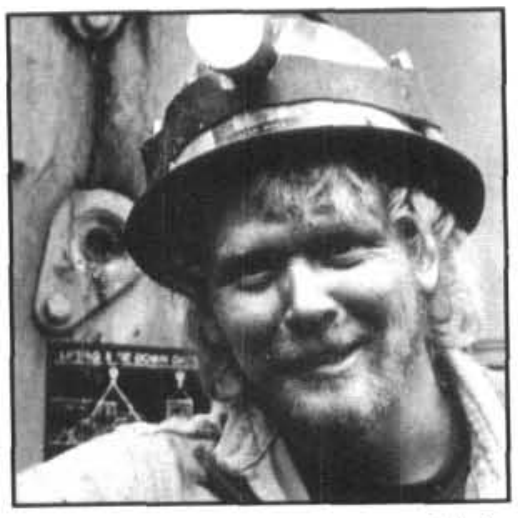

Echo Bay

\section{PRODUCTION}

For the first time since 1925, the value of base metal production far exceeded the value of precious metals production.

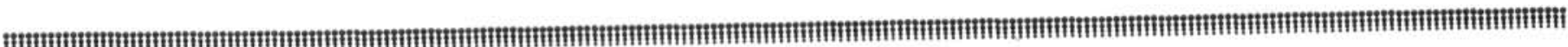

\section{INTRODUCTION}

The value of Alaskan mineral production in 1990 was $\$ 533$ million, an increase of 93 percent from the $\$ 277$ million produced in 1989 (table 7). The respective value percentages are: zinc, 48; gold, 17; silver, 10; coal, 8; sand and gravel, 7; lead, 6; and all others, 4. Mineral production sites include at least $290 \mathrm{coal}$, hardrock and placer metal mines, and aggregate and stone quarries statewide. Principal metallic, nonmetallic, and quarry locations are shown in figure 24.

Production estimates are based on data compiled from 204 DGGS questionnaires returned by companies and individuals; responses from an additional 15 sand, gravel and stone quarry operators; summaries supplied by the Department of Transportation and Public Facilities and U.S. Forest Service; and bullion sale volume from precious metal refiners. Historical production of gold, sand and gravel, and coal are graphically depicted in figures 25 , 26, and 27 respectively. Additional production estimates for 10 metals and other industrial minerals (appendixes $F, G$ ) show that a wide variety of mineral commodities have been produced and shipped to markets since the early 20th century.
Mineral production was dominated by metals for the fourth consecutive year, and collectively metals accounted for 80 percent of total product value. However, unlike most previous years, a base metal, zinc, was the most valuable commodity. Gold, although important in terms of overall employment

Figure 24. Location of principal gold mining camps, coal mines, and industrial mineral sites in Alaska, 1990.

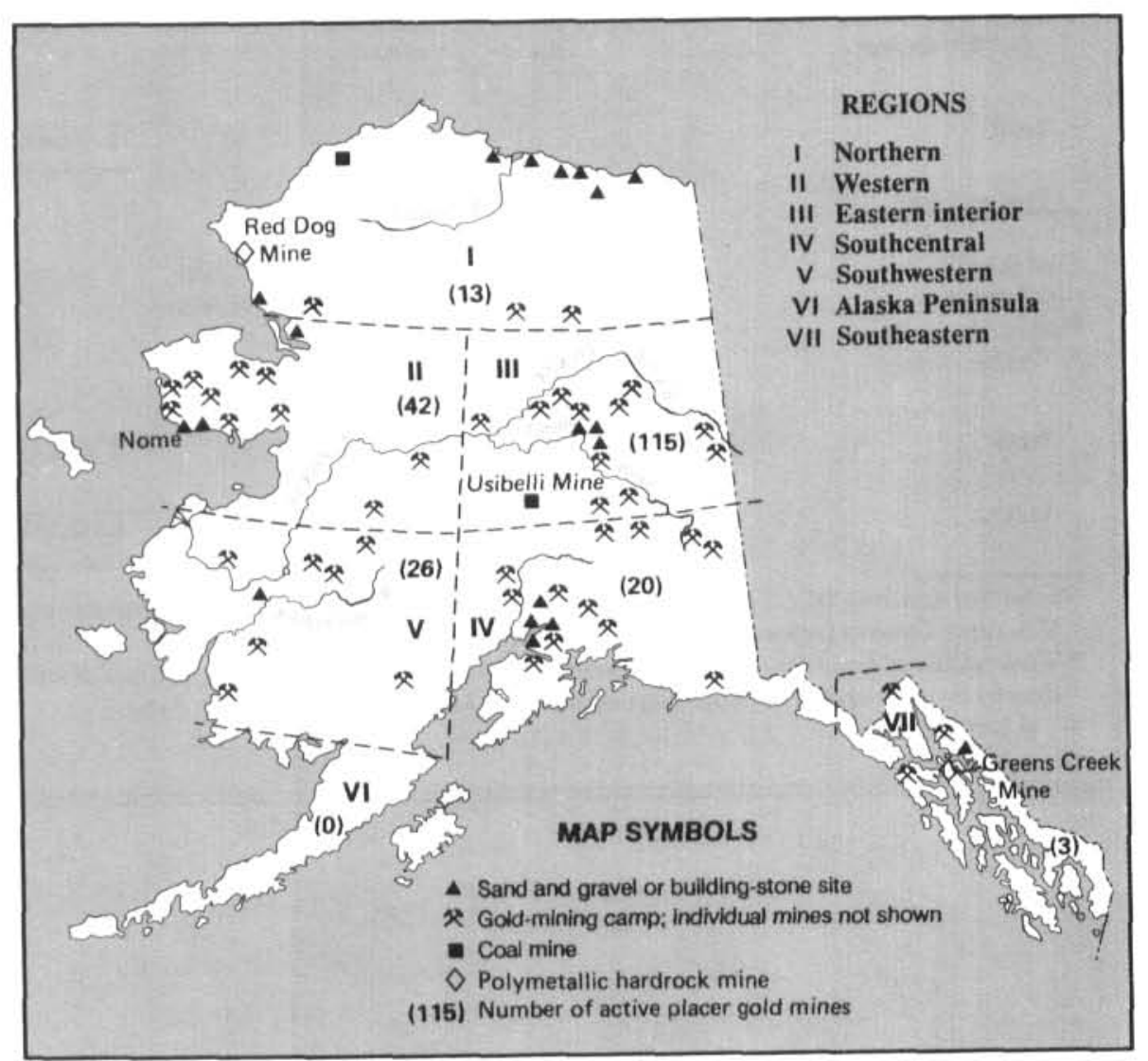


Table 7. Reported mineral production in Alaska, 1988-90

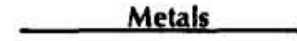

Gold (ounces) (kilograms)

Silver (ounces) (kilograms)

Platinum (ounces) (grams)

Lead (tons) (tonnes)

Zinc (tons) (tonnes)

Mercury (pounds) (kilograms)

Tin (pounds) (kilograms)

Tungsten (short ton units) (kilograms)

\section{Total}

\section{Industrial minerals}

Jade and soapstone (tons) (tonnes)

Sand and gravel (million tons) (million tonnes)

Building stone (million tons) (million tonnes)

Total

Coal and peat

Coal (tons) (tonnes)

Peat (cubic yards) (cubic meters)

Total

TOTAL
Quantity

\begin{tabular}{|c|c|c|}
\hline 1988 & 1989 & 1990 \\
\hline 265,500 & 284,617 & 231,700 \\
\hline 8,258 & 8,852 & 7,206 \\
\hline 47,790 & $5,211,591$ & $10,135,000$ \\
\hline 1,486 & 162,102 & 315,199 \\
\hline 25 & W & - \\
\hline 777 & W & \\
\hline - & 9,585 & 44,220 \\
\hline -. & 8,698 & 40,106 \\
\hline-- & 19,843 & 181,200 \\
\hline - & 18,007 & 164,350 \\
\hline w & W & - \\
\hline W & W & \\
\hline 300,000 & 194,000 & 57,000 \\
\hline 136,080 & 87,988 & 25,855 \\
\hline 240 & -. & 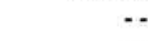 \\
\hline 2,181 & $\cdots$ & . \\
\hline
\end{tabular}

\section{$\$ 114,096,700$}

$\$$

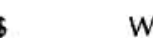

$48,750,508$

W

51.7

14.4

13.1

2.9

2.6

3.3

$$
\begin{array}{r}
W \\
15.0 \\
13.6 \\
3.2 \\
2.5
\end{array}
$$

$24,650,000$

$\$ 73,400,508$

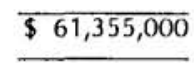

$\$ 62,921,500$

$\overline{\$ 173,811,955}$

$\$ 424,713,000$

672,000

200,000

$30,954,000$

$253,680,000$

w

4,000

$73,400,508$

$\$ 44,300,000$

375,000

$\$ 41,464,800$

352,000

$\$ 44,990,000$

$1,407,214$

55,000

42,053

$1,317,574$

51,000

38,995

65,000

49,699

\section{$\overline{\$ 44,675,000}$}

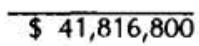

$\$ 45,390,000$

\section{$\$ 232,172,208$}

\section{$\$ 533,024,500$}

AProduction data from DGGS questionnaires, phone interviews with mine operators, Alaska Department of Transportation and Public Facilities, the U.S. Army Corps of Engineers, and other confidential sources.

"Values calculated from 1990 annual price averages of gold, silver, platinum, zinc, and lead as reported in the "Mining Journal"; other values supplied directly by mine operators. Coal-value estimates include some in-state freight costs.

-. - Not reported.

W - Withheld. 
and diversity, dropped to second place. Zinc's climb to the top is attributed solely to the first-year production at the Red Dog Mine and a second consecutive year of concentrate exports from the Greens Creek Mine on Admiralty Island. These two properties supplied fully 55 percent of the United State's domestic mine output of zinc, and reduced the country's net import reliance on zinc from about 61 to 48 percent during the year.

Silver also added luster to Alaska's mines. In 1990 an estimated $10,135,000$ oz was recovered, 74 percent of which came from the Greens Creek Mine, the nation's largest silver producer for the second consecutive year. The 315 metric-ton total, about 18 percent of U.S. mine production of silver, was enough to rank Alaska the third largest producer of silver behind Idaho and Nevada.

Lead, essentially produced as a byproduct at the Greens Creek and Red Dog Mines, was also nationally ranked and amounted to about 10 percent of U.S. domestic mine output.

The positive upward movement of lead, zinc, and silver was offset by the 20 percent drop in both volume and value of gold (tables 7, 8). Alaska's gold miners faced a relatively weak price of about $\$ 382 / o z$ in 1990 and several significant mine shutdowns.

\section{Greens Creek Mining Company} became the largest gold producer in Alaska for the year with $38,103 \mathrm{oz}$ and earned the unique distinction of being the only mine in Alaskan mining history to be the leading producer of both gold and silver during a calendar year. This achievement was balanced by Westgold's announcement that the BIMA offshore gold dredging operation was uneconomic and was permanently suspended at the end of the dredging season late in October. The Valdez Creek Mine, previously Alaska's largest gold mine for five of the last six years, was inoperative for most of 1990 although some production did occur during a six-week sluicing period in September and October by Cambior Mines, the new operator.

Hence, the dynamics of Alaska's gold mining industry continued to fluctuate in response to complex economic factors and the demands of new state and

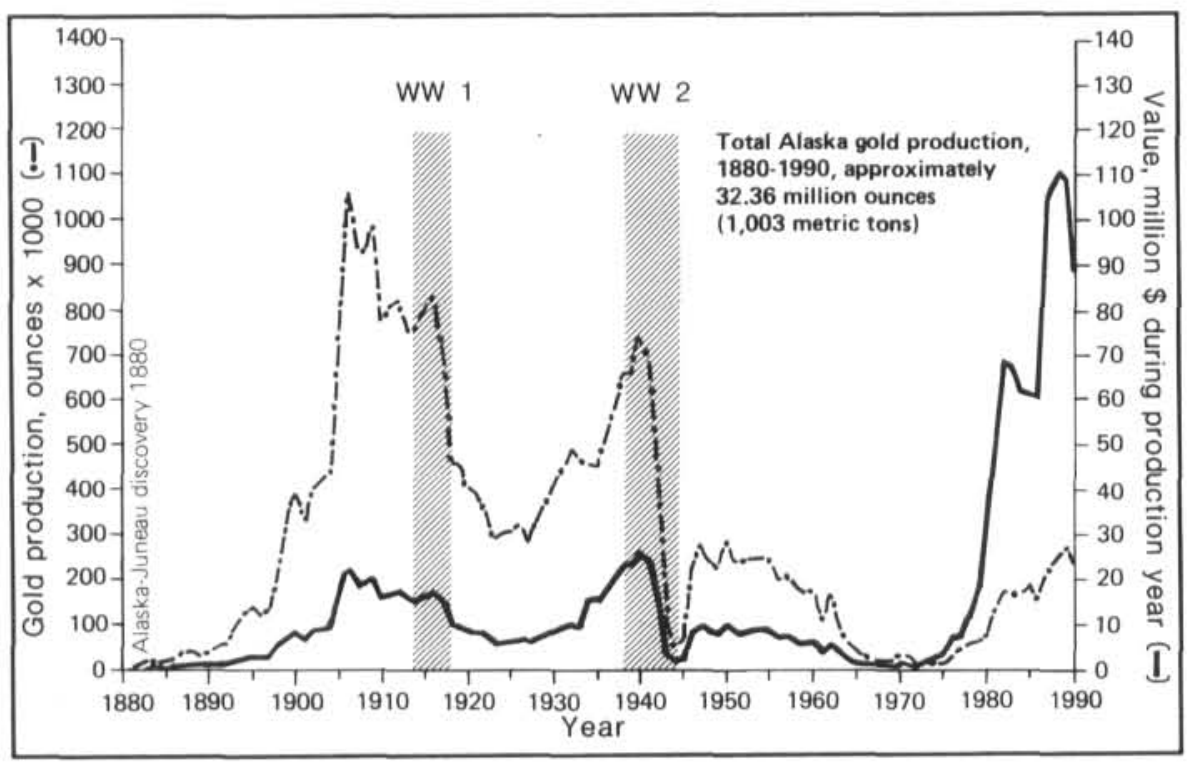

Figure 25. Cold production in Alaska, 1880-1990.

Figure 26. Sand and gravel production in Alaska, 1950-1990.

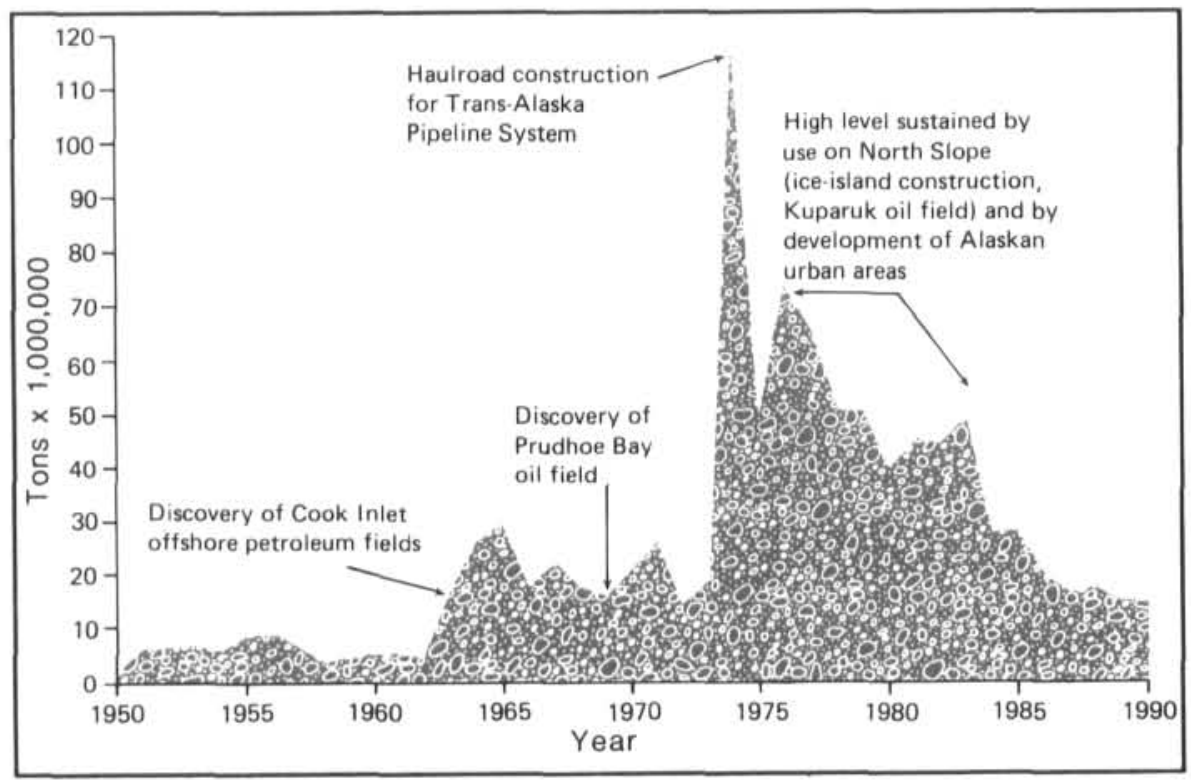


federal regulations. Alaska's 10 largest producers-Greens Creek Mining Company, Alaska Gold Company, Westgold, Cambior Mines, Inc., Polar Mining, Anvil Mining, Sphinx Mining, Alaska Placer Development, Nyac Mining, and Citigold Alaska, Inc. produced 114,083 oz of gold or 49 percent of statewide bullion output. Alaska's 10 largest mines in the previous three calendar years produced 61 ,

Figure 27. Coal production in Alaska, 1915-1990. 59, and 58 percent of the statewide

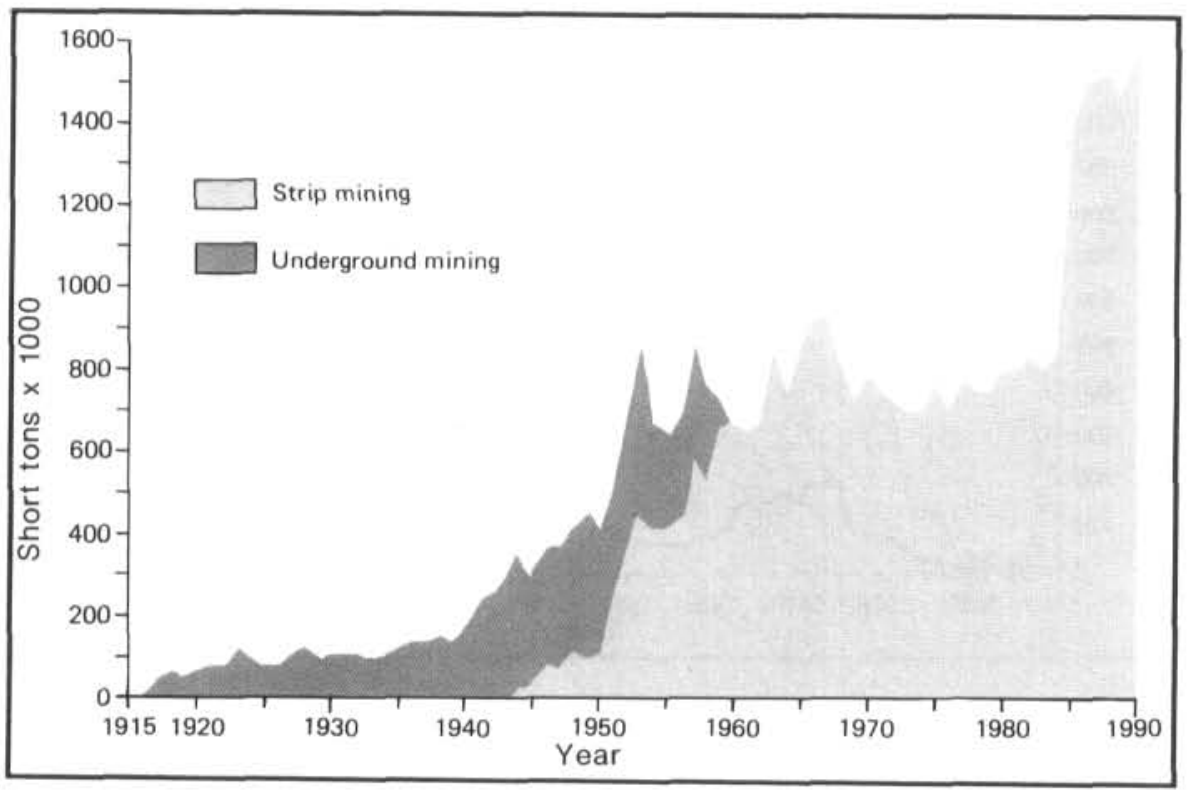

total respectively. Evidently a shift to smaller operations took place in 1990, despite the improved performance of the Greens Creek Mine. In 1990 about 83 percent of gold bullion came from placer mines; the remaining 17 percent was recovered from two hardrock properties. The mean average output for an Alaskan gold mine amounted to $892 \mathrm{oz}$, compared to $1,143 \mathrm{oz}$ in 1989 and 1,282 oz in 1988; these statistics also reinforce the contention that smaller operations took a greater share of the gold in 1990 than in the previous three years. Unit-cost data of selected placer gold mines is summarized in table 9. The figures are based on company estimates of the cost of producing an ounce of gold during the 1989 and 1990 seasons.

Although the mine population represented is only about 10 percent of the total mechanized placer mines in operation, the same trends occur during the two reporting years. The smallest and largest placer operations experience higher costs than medium-sized ventures, which are apparently the most economical on a unit-cost basis.

Table 8. Reported refined gold production, number of operators, and industry employment in Alaska, 1989-90

\begin{tabular}{||ccr}
\multicolumn{1}{l}{ Region } & \multicolumn{2}{c}{ Number of operators } \\
Northern & $\underline{1989}$ & $\underline{1990}$ \\
Western & 13 & 11 \\
Eastern interior & 115 & 115 \\
Southcentral & 21 & 20 \\
Southwestern & 26 & 26 \\
Southeastern & 4 & 4 \\
TOTAL & & $\mathbf{2 1 8}$
\end{tabular}

\section{Production in ounces of gold

$\underline{1989}$ \\ $\underline{1990}$}

6,800

$(211 \mathrm{Kg})$

87,500

$(2,721 \mathrm{Kg})$

79,300

$(2,466 \mathrm{Kg})$

73,100

$(2,273 \mathrm{Kg})$

13,950

$(434 \mathrm{Kg})$

24,967

$(776 \mathrm{Kg})$

284,617

$(8,881 \mathrm{~kg})$
4,750

$(148 \mathrm{Kg})$

79,100

$(2,460 \mathrm{Kg})$

78,480

$(2,441 \mathrm{Kg})$

16,670

$(518 \mathrm{Kg})$

14,400

$(448 \mathrm{Kg})$

38,300

$(1,191 \mathrm{Kg})$
Number of employees

$\underline{1989} \quad \underline{1990}$

$38 \quad 35$

$437 \quad 400$

$494 \quad 495$

$280 \quad 160$

$102 \quad 100$

$126 \quad 135$

231,700

$(7,206 \mathrm{~kg})$ 


\section{METALS}

\section{Northern Region}

Cominco Alaska Inc. mined 1,318,200 tons of zinc-lead-silver ore from the Red Dog deposit north of Kotzebue in its first year of commercial operation. Red Dog is a shale-hosted stratiform zinc-leadsilver deposit located in the De Long Mountains of the northwestern Brooks Range and is owned by NANA Regional Corporation. The first year of mining could take place only after four years and $\$ 415$ million expended in the development of what has been described as one of the largest and richest zinc deposits ever found (Kennedy, 1990). Final mine development involved the integration and cooperation of Cominco (as operator), NANA Corporation (the owner), and the State of Alaska, which financed the De Long Mountains Regional Transportation System.

The shale-hosted Red Dog deposit contains inferred reserves of 85 million tons of 17.1 percent zinc, 5 percent lead, $2.4 \mathrm{oz} /$ ton silver and a significant but presently nonrecoverable barium resource. The nearly flat-lying, shallow ore bodies are mined by open-cut mining methods. During 1990 mining rates increased to about 4,000 tons/day, with about 6,000 tons/day expected in 1991. A small fleet of heavy equipment strips overburden and mines the ore bodies. These include a $13 \mathrm{yd}^{3}$ loader, four 85 -ton-rated haul trucks, two bulldozers, and a grader (Kennedy, 1990).

The Red Dog mill facilities are approximately one-half mile from the mine site, and consist of a power plant, concentrator, and storage unit (fig. 28). Column-cell flotation yielded about 321,700 tons of concentrates. These were trucked down the 52-mi haul road to a port site near Kivalina in specially-designed 75-ton trucks under contract by Arrow Transportation International of Seattle, Washington. During the 100-day shipping season, Foss Maritime Inc., also of Seattle, barged the concentrates from the shallow-water port near Kivalina to eight ocean-going ships that ranged in size from 25,000 to 70,000 tons. The concentrates were then shipped to Cominco's

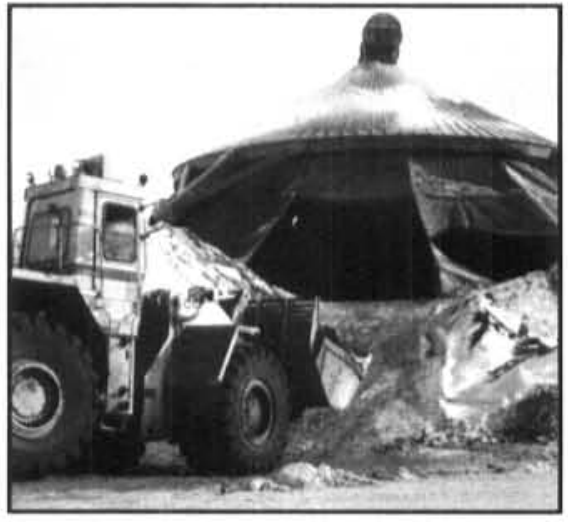

Figure 28. Technology has been developed to permit year-round operations at the Red Dog Mine, above the Arctic Circle. (Photo by Cominco)

Table 9. Production costs for selected Alaskan placer gold mines, 1989-90

\begin{tabular}{|c|c|c|c|c|c|c|c|c|}
\hline \multirow[t]{2}{*}{ Mine size } & \multicolumn{2}{|c|}{ Number of mines } & \multicolumn{2}{|c|}{$\begin{array}{l}\text { Production in } \\
\text { ounces of gold }\end{array}$} & \multicolumn{2}{|c|}{$\begin{array}{c}\text { Total reported } \\
\text { mine cost }\end{array}$} & \multicolumn{2}{|c|}{$\begin{array}{l}\text { Unit cost } \\
\text { per ounce }\end{array}$} \\
\hline & $\underline{1989}$ & $\underline{1990}$ & $\underline{1989}$ & 1990 & $\underline{1989}$ & 1990 & $\underline{1989}$ & $\underline{1990}$ \\
\hline $\begin{array}{l}\text { Small }(50-650 \mathrm{oz} \\
\text { gold/yr) }\end{array}$ & 11 & 8 & 2,977 & 1,856 & 784,177 & 560,600 & $\$ 263$ & $\$ 302$ \\
\hline $\begin{array}{l}\text { Medium }(650-2,500 \mathrm{oz} \\
\text { gold/yr) }\end{array}$ & 5 & 11 & 6,461 & 12,132 & $1,538,000$ & $3,314,000$ & 238 & 273 \\
\hline $\begin{array}{l}\text { Large }(>2,500 \mathrm{oz} \\
\text { gold/yr) }\end{array}$ & 5 & 5 & 98,816 & 54,497 & $31,972,300$ & $18,990,000$ & 324 & 348 \\
\hline TOTAL & 21 & 24 & $\begin{array}{r}108,253^{4} \\
(3,359 \mathrm{~kg})\end{array}$ & $\begin{array}{r}68,485^{b} \\
(2,124 \mathrm{~kg})\end{array}$ & $\$ 34,294,477$ & $\$ 22,864,600$ & $\$ 317$ & $\$ 333$ \\
\hline
\end{tabular}

-43 percent total placer gold.

b36 percent total placer gold. 


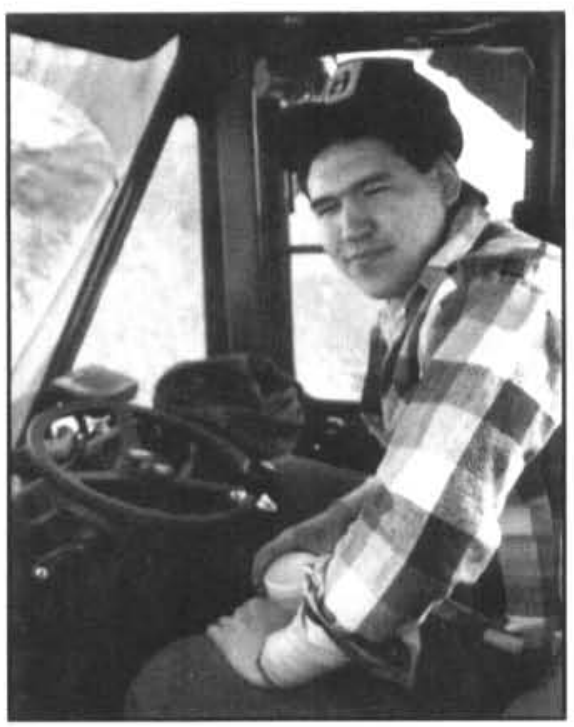

Figure 29. The Red Dog Mine in northwest Alaska is a joint venture between NANA Regional Native Corporation and Cominco Alaska, Inc. It has become a model of the training and employment of corporation shareholders. By organizing shifts four weeks on and two weeks off, employees can return to their villages and participate in cultural events and traditional hunting activities. (Photo by Cominco)

smelter in Trail, British Columbia, and to several European and Far Eastern destinations. Our estimates of mineral production from Red Dog include only concentrates shipped to market in 1990 $(321,700$ tons), consistent with Cominco's own production accounting system.

The 1990 production of concentrates was about 44 percent of the planned production of 720,000 tons annually of zinc, lead, and bulk concentrates. Because unexpectedly high amounts of oxidized ore were encountered, lead and silver recoveries were initially below that forecasted from development tests. This

necessitated a costly redesign of the semi-autogeneous milling circuit and flotation-column cells. By the fall of 1990, recovery of all three metals-zinc, lead, and silver-had nearly reached the planned amounts.
Metal contamination of Red Dog Creek and Wulik River from groundwater sources at the Red Dog Mine caused concern during 1990. Although Red Dog Creek naturally contains toxic levels of trace metals due to erosion of the dissected ore body, groundwater seepage and failure to contain flood-level runoff waters from the tailings dam resulted in regulatory enforcement and fines issued by the Alaska Department of Environmental Conservation. Cominco implemented extensive mitigation measures during the year including a rerouting of Red Dog Creek, and elimination of pit water seepage through sump pumps, water treatment and other measures. The mine's water treatment plant is designed to remove heavy metals from the tailings pond effluent and ensure that water used in the flotation circuit is not contaminated with heavy metals. Within the mill complex, two local species of fish, arctic char and grayling, are kept in test tanks containing mine effluents and fresh water; fish tissues are routinely analyzed to determine trace metal concentrations. Acceptable metal concentrations in groundwater test-wells were reached late in the year.

Red Dog Mine employed a workforce of about 300 for most of the year, including technical and engineering consultants brought into the project to solve the milling and water quality problems (fig. 29). The mine is expected to reach full-scale production in 1992.

Placer mining activities in the northern region were confined to the central Brooks Range districts of Wiseman, Chandalar, and Wild Lake. Eleven mines reported a total production of $4,750 \mathrm{oz}$ of gold in 1990, down from $6,800 \mathrm{oz}$ reported from 13 companies in 1989. According to returned questionnaires, the most difficult challenges for miners to meet were the new water recycle and reclamation requirements.

Dave Ketscher worked the South Fork of the Koyukuk River with small scale mining equipment. Paul Dionne searched for nuggets in underground drifts on the Hammond River using a metal detector. Other Wiseman area miners in production include: Outland Resources Group on Chapman Creek and Koyukuk River; Paradise Valley Mining on Birch Creek near Wild Lake (which also operated a recreational mining venture for tourists); Dan Even on Jim Pup and California Creek; Wild River Ventures on Lake Creek; Robert Aumiller on Prospect Creek; Northern Lights Mining on Jay Creek; and Steve Greene and Jon Brewis on Rocker and Davis Creeks. Chandalar Mines, Inc. leased placer ground from Chandalar Development Corporation (Eskil Anderson) and reopened the Tobin Creek placer ground after several years of dormancy (fig. 30). This larger-scale mining venture became the northern region's biggest producer of gold in 1990.

\section{Western Region}

Estimated 1990 production region-wide is $79,100 \mathrm{oz}$ of gold, down about 10 percent from the 1989 level of $87,500 \mathrm{oz}$. Production was derived from 42 placer mines, about the same number that was active in 1989. The placer mining industry, the only source of metallic mineral production in the western region, was jolted by the termination of Westgold's BIMA offshore dredging venture. Westgold Ltd., the BIMA's owner announced in late October that they would sell the dredge (the world's largest) and sell its 22,000 acres of state offshore mining leases near Nome, Alaska (fig. 31). Despite five years of 
knowledge gained from research and development while mining the offshore placer deposits, the BIMA never lived up to its expected annual take of $50,000 \mathrm{oz}$ of gold. The economics of the operation were further compounded by unexpected costs associated with overwintering of the vessel, a progressively decreasing price of gold, some unresolved gold recovery problems, and costly mechanical failures.

With knowledge from the BIMA operation, the company pioneered a smaller undersea mining method that involves a tracked, submersible suction dredge remotely controlled from a surface vessel. Test mining in 1990 recovered nearly $700 \mathrm{oz}$ of gold. Westgold also pioneered environmental monitoring of the subsea environment, and spent several million dollars annually studying marine organisms, sampled for trace elements in sea water, and reduced turbidity of mine wash effluent from the dredge. Westgold is also to be commended for its commitment to local hire, which involved intensive on-the-job training of Nome area residents. In 1990 Westgold employed 125 workers during the mining season and recovered $15,200 \mathrm{oz}$ of refined gold, about half the normal seasonal take, before permanently shutting down the operation. Total production by Westgold offshore Nome, Alaska from 1986-1990 was $121,861 \mathrm{oz}$ of refined gold with the best annual recovery in 1987 when BIMA produced $36,500 \mathrm{oz}$.

Alaska Gold Company continued to operate two Yubaclass, bucket-line stacker dredges onshore in the Nome gold fields. Dredge 6 worked the western extension of the first strandline deposit submarine beach west of the Nome airport. Dredge 5 worked about $3 \mathrm{mi}$ northeast of town on the third, or Monroeville

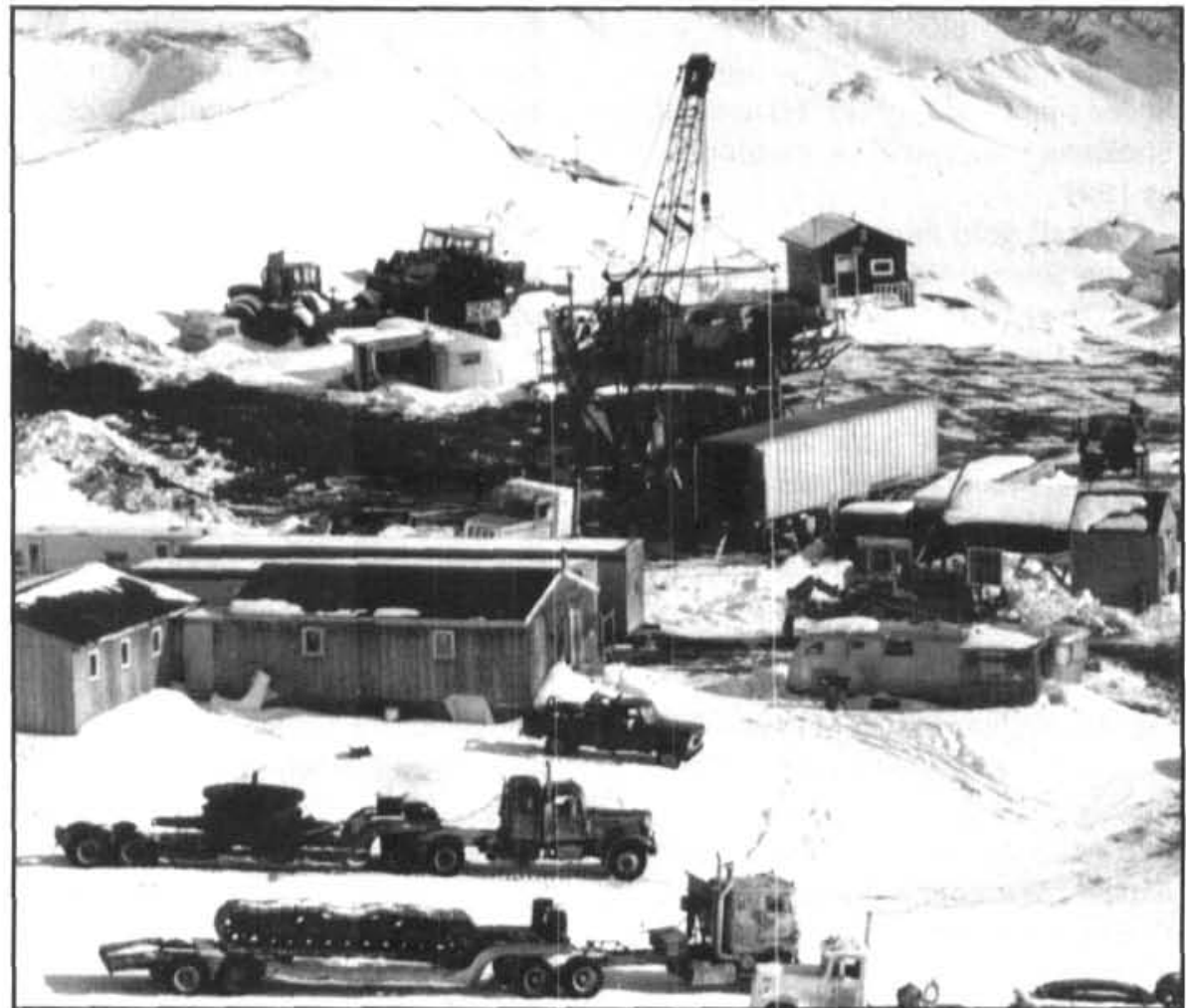

Figure 30. Working in remote sites in Alaska requires a sizable equipment and transportation infrastructure, even on smaller operations. This staging area is part of the Chandalar Mine, Inc., operation on Tobin Creek on the south side of the Brooks Range. (Photo by Bruce Campbell)

beachline at its intersection with the floodplain of Dry Creek. Both dredges, which operate at daily capacities of about $9,000 \mathrm{yd}^{3}$, were shut down in early November after a 160 day operating season that began in May. Alaska Gold Company employs about 135 seasonally, and is the largest private sector employer in the Nome area. Gold production from all Alaska Gold Company sources in the western region was 24,000 oz in 1990.

The remaining 40 placer mines that mined in the western region worked ground on the Seward Peninsula, at Hogatza, and in the Ruby-Poorman and Tolstoi districts. Large operations on the Seward Peninsula include: Anvil Mining on Anvil Creek, Nome district; GHD Resources at Kiwalik Flats, Candle district, and Bud Meyers and Associates on Mud Creek, Candle district. GHD's Kiwalik Flats opera-
Figure 31. Westgold's BIMA offshore dredge completed its five-year assignment near Nome this year and moved out of state. Its operation was a revolutionary effort to mine marine placers in Norton Sound, off the coast of western Alaska. During its service in Alaska, the BIMA produced $122,000 \mathrm{oz}$ of gold and maintained a positive record of local hire and high environmental standards. (Photo by Westgold, Inc.)

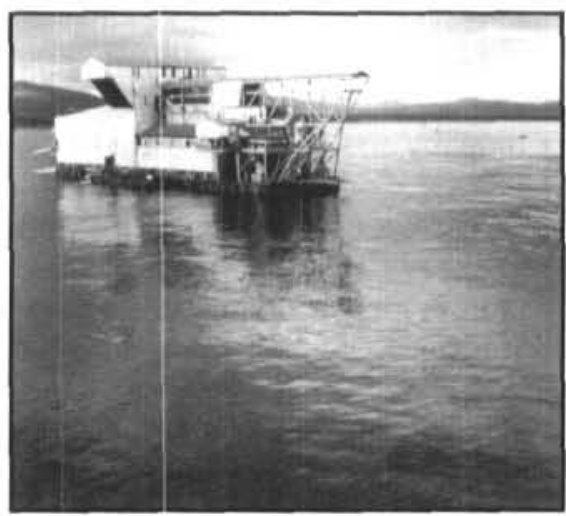


tion was refurbished late in the season (winter) with a new jigbased plant built by R.J. Hanson of Spokane, which will be employed in 1991.

Small gold mining firms active on the Seward Peninsula include: N.B. Tweet and Sons on Henry Creek, Kougarok district (a small dredging operation); Edwin Hatch and Tom Johnson (separate operators) on Sweepstakes Creek, Koyuk district; Howard Smith on Little Rocker Creek, Nome district; Bert Pedigrew on Speciman Gulch, Nome district; Paul Steinhacher on Iron Creek, Casedepaga district; Darrell Walker on Clara Creek, Nome district; Allen Vezey on Hastings Creek, Nome district; Mark Gumaer on Macklin and Dick Creeks, Serpentine district; Alaska Placer Development on Solomon River, Solomon district; Jerry Pushcar on Nelson Creek, Council district; Mathisen and Christopherson on Eagle and Iron Creeks, also in the Council district; Hugo Lindfors and C.M. Reader on Dome and Telegraph Creeks, Council district; Roger Nordlum on Candle Creek; and Inmachuk Gold on Inmachuk River. Global Resources continued a tourist-recreational mining program with the old American Creek Flume dredge and pick-and-shovel opportunities for enterprising argonauts on the Penny River west of Nome.

Taiga Mining leased the Alaska Gold Company's Hog River Dredge at Hogatza in the Hughes district, and dredged the left limit of the previously mined ground during the 1990 season. The Alaska Gold Company and its predecessor, USSR\&M Company,operated the $6 \mathrm{ft}^{3}$ dredge from 1957 to 1983 and recovered over $220,000 \mathrm{oz}$ of gold from the remote mining district on the lower Koyukuk River drainage.

Sphinx Mining, Inc. operated the largest placer mine in the RubyPoorman district on Midnight Creek about $30 \mathrm{mi}$ south of the Yukon
River. The company employed 10 men to recover $\$ 1.6$ million in bullion including a byproduct of placer tin and silver.

Other mining companies active in the area include: Flat Creek Mining Company on Flat Creek; Mike Hartman on Poorman Creek; Yukon Mining Company (Joel Ramsted) on Illinois and Golden Creeks; Ross Novak on Boothby Creek; Conrad House on Swift Creek; Green Mining and Exploration on Long Creek; Mike Sweetsir on Trail Creek; Howard Miscovich on Poorman Creek; and Keith Tryck on Ophir Creek. South of the Ruby-Poorman district in the Tolstoi area, Rosander Mining worked middle Colorado Creek with a newly designed plant employing water recycling and containment. Castle Ridge Mining worked Alamin Mining Company's nearby Bear Creek ground, but reported disappointing results at the end of the season.

\section{Eastern Interior Region}

The eastern interior region was second only to the western region in gold production in 1990. An estimated $78,480 \mathrm{oz}$ of refined gold were taken from the region's 115 gold mines in 1990, compared to a similar amount $(79,300 \mathrm{oz})$ from the same number of mines in 1989. Employment levels were 495 or the same as the previous year. This area includes mining districts in the Yukon-Tanana Upland where many of Alaska's largest placer districts are located. Although larger operations do exist or are on the drawing board, placer and lode mining is dominated by relatively small businesses that employ four or fewer and operate more on the economic scale of a typical mid-west family farm or Alaskan commercial fishing venture.

The Fairbanks district was again the largest producer of gold in the eastern interior and the focus of accelerated exploration efforts for hardrock minerals (fig. 32). We estimate that the district's 27 placer mines and two lode mines produced $27,800 \mathrm{oz}$ of gold and 5,500 oz of byproduct silver worth $\$ 10.7$ million; the industry created about 190 jobs, including 158 at placer mines and 32 at lode mines. Employment and production estimates are about 20 percent lower than in 1989. This decrease is mainly attributed to reduced output from lode mines.

Citigold Alaska operated Alaska's only commercial lode heap leach gold mine, but at a much reduced scale from previous years. Their 1990 mine efforts at the Ryan Lode Mine on Ester Dome, northwest of Fairbanks, concentrated on removing gold and silver with sodium cyanide from existing heapleach pads, and on exploration drilling of potentially new types of ore bodies. About 2,500 oz of gold and 2,200 oz of silver worth $\$ 960,000$ were mined from the heaps. The company continued to work out complex problems related to groundwater-well monitoring raised by Department of Environmental Conservation and issues raised by local special interest groups such as Common Ground, an Ester-based community organization. Company officials announced late in the year that negotiations were underway to sell the mine properties.

Polar Mining, Inc. was the largest gold mine in the eastern interior and one of the five largest producers of gold statewide. The company operated three mining enterprises during the year: (1) a large open-cast placer mine on Goldstream Creek adjacent to Ester Dome; (2) a smaller placer mine on Fairbanks Creek at the eastern end of the district; and (3) an experimental bulk sampling and mining operation on the Christina vein on Cleary Summit utilizing a ball mill and simple gravity recovery. The lode on Cleary Hill was leased from Fairbanks Exploration, a local mining group, and the two larger placer 
properties were located on patented mining claims leased from the Alaska Gold Company. Polar Mining works 350 days per year in development and production. In 1990 the company had 28 yearround employees and as many as 15 seasonal workers.

Alaska Gold Company also leased placer ground to the following companies and individuals: Alf Hopen on Dome Creek; Walter and Ron Roman on Fish Creek (separate mines); and SVZAL on lower Eldorado Creek (a drift mining development).

Other Fairbanks district mine operations active in 1990 include: Cooks Mining on Fairbanks Creek; Jack Neubauer on Fox Creek; Don Stein on Pedro Creek; Andy Miscovich on Chatham Creek; Dwayne Savage on Last Chance Creek; Alex Twogood on Goldstream Creek; Jim Childs on Nugget Creek (a new venture on the north side of Ester Dome); Howard Lambert on Ester Creek; Carson Holt on Willow Creek; and Jerry Hassel and Roger Moore on Ready Bullion Creek (separate operations).

Don Read again operated a small drift mine on Treasure Creek on the north side of the district. He also reprocessed old tailings left from the pre-World War II drift mines-an activity that is expected to increase district wide in the next few years.

Roberts Mining operated their Dome Creek drift mine below the lower limit of USSR \& M dredge tailings on that drainage (fig. 33). During the winter of 1990, the company brought to the surface about $15,000 \mathrm{yd}^{3}$ of pay, which was stockpiled for summer sluicing. Gravels sluiced in 1990 exceeded the $0.04 \mathrm{oz} / \mathrm{yd}$ grade recovered in 1989 , and an even larger take is expected in 1991. The two-man crew drills with a jack-leg, and blasts with ANFO, using gelatin primers. Each round releases about $25 \mathrm{yd}^{3}$ of pay and overburden.

The Circle mining district northeast of Fairbanks experienced mining activity levels more-or-less the same as 1989. The Circle district still contains the largest concentration of placer mines in Alaska, but is dominated by smaller operations (fig. 34). An estimated 52 Alaska Placer Mining Applications were processed, but only 37 of the companies actually sluiced pay.

Some of the larger operations of the 1990 season include: Paul and Company on Porcupine Creek; Greenhorn Mining (Stan Gelvin) on Crooked Creek; and Alaska Ventures (Vince Halverson) on Mammoth Creek. Other placer mines active in 1990 were Gold Post Mining on Deadwood Creek; Superstock Mining on Crooked Creek; Ron Wrede on Deadwood Creek; Points North (Bob Cacy) on Portage Creek; Jim Belfield on Switch Creek; Steve Olson on Eagle Creek; Dugger Mining Company on Mastodon Creek; Lyle Colledge and Vern Stepp on Bottom Dollar Creek; Magic Circle Mining on Deadwood Creek; Aurora Mining on Pup Creek; John Sipes on Deadwood Creek; Dick Blevins on Portage Creek; John Hendrickson on Sourdough Creek; George Seuffert on Cripple Creek; Last Hope Mining on Harrison Creek; Clyde Henry on 43 Pup; and Goldstream Exploration on Mastodon Creek.

Goldstream obtained a $\$ 200,000$ grant from the Alaska Science and Technology Foundation to design and implement a commercial washing plant and excavation method that reduces the amount of process water necessary for sluicing, and simultaneously reclaims land during placer mining. Test results showed that both objectives were achieved with a $50 \mathrm{yd}^{3} / \mathrm{hr}$ operation that was

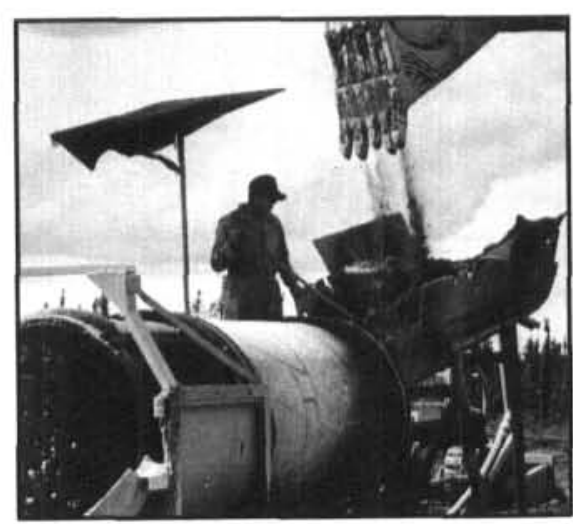

Figure 32. Alaska is currently the largest producer of placer gold in North America. There are $\mathbf{2 2 0}$ active operations in the state. This two-man operation at Democrat Bench is typical of many mines but is unusual in its high recovery efficiency. (Photo by Bruce Campbel)

Figure 33. In the early days of Fairbanks, many placer operations were underground drift mines. Coldbearing gravels were hauled to the surface all winter and then washed in the summer when water was available. Technology now enables miners to excavate old stream channels 100 to $140 \mathrm{ft}$ below the surface. At the Dome Creek Drift Mine, father and son operators prepare to blast gravel at the work face. (Photo by Bruce Campbell)

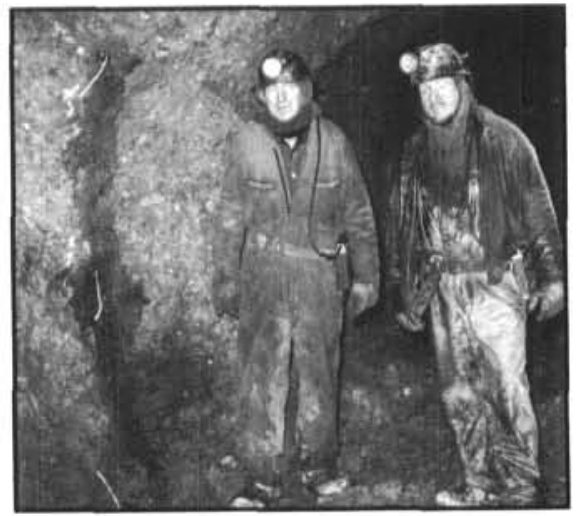




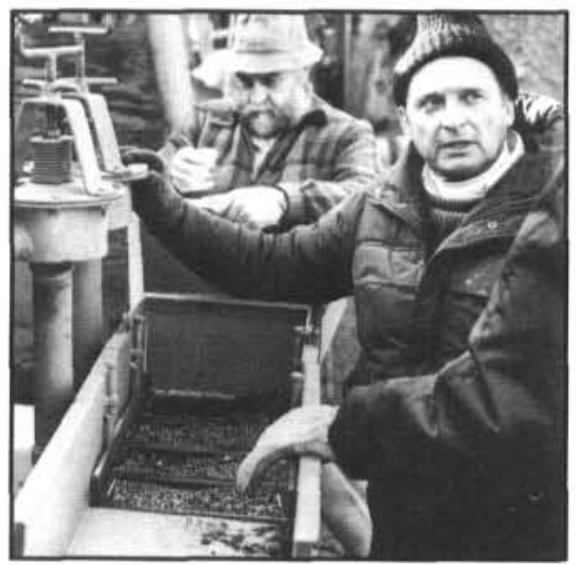

Figure 34. Efficient recovery is critical to the profitability of all placer operations. The owner and operator explains the action of the shot-loaded recovery boxes in his jig system. As the gravel is washed, heavy particles like gold sink through the ball bearings while lighter material is pulsed off. The gold is collected in the sump. (Photo by Bruce Campbell) commercially operational in 1990 (fig. 35).

Three placer mines reported production in the Livengood district. Scott Rendich worked a small paystreak on Willow Creek, and Dick Geraghty mined pay on Olive Creek. Alaska Placer Development was again the largest placer mine in the area, as it has been for the last six or seven years. The company hydraulically stripped barren muck from the Livengood Bench and worked pay from a paystreak on an irregular limestone bedrock. Process waters were recycled through a complex recirculation system. The operation benefits from earlier attempts to mine the bench. In 1982 Livengood Joint Ventures, the previous mine developer, constructed a 160-acre containment pond below the mine workings. This pond is now effectively used

Figure 35. Caring for the environment often generates new technology to resolve operational challenges in Alaska. Coldstream Exploration received a grant from the Alaska Science and Technology Foundation to develop a new system for washing placer gravels. This spiral jig washing plant reduces the amount of water needed while it allows for simultaneous reclamation of the property. (Photo by Bruce Campbell)

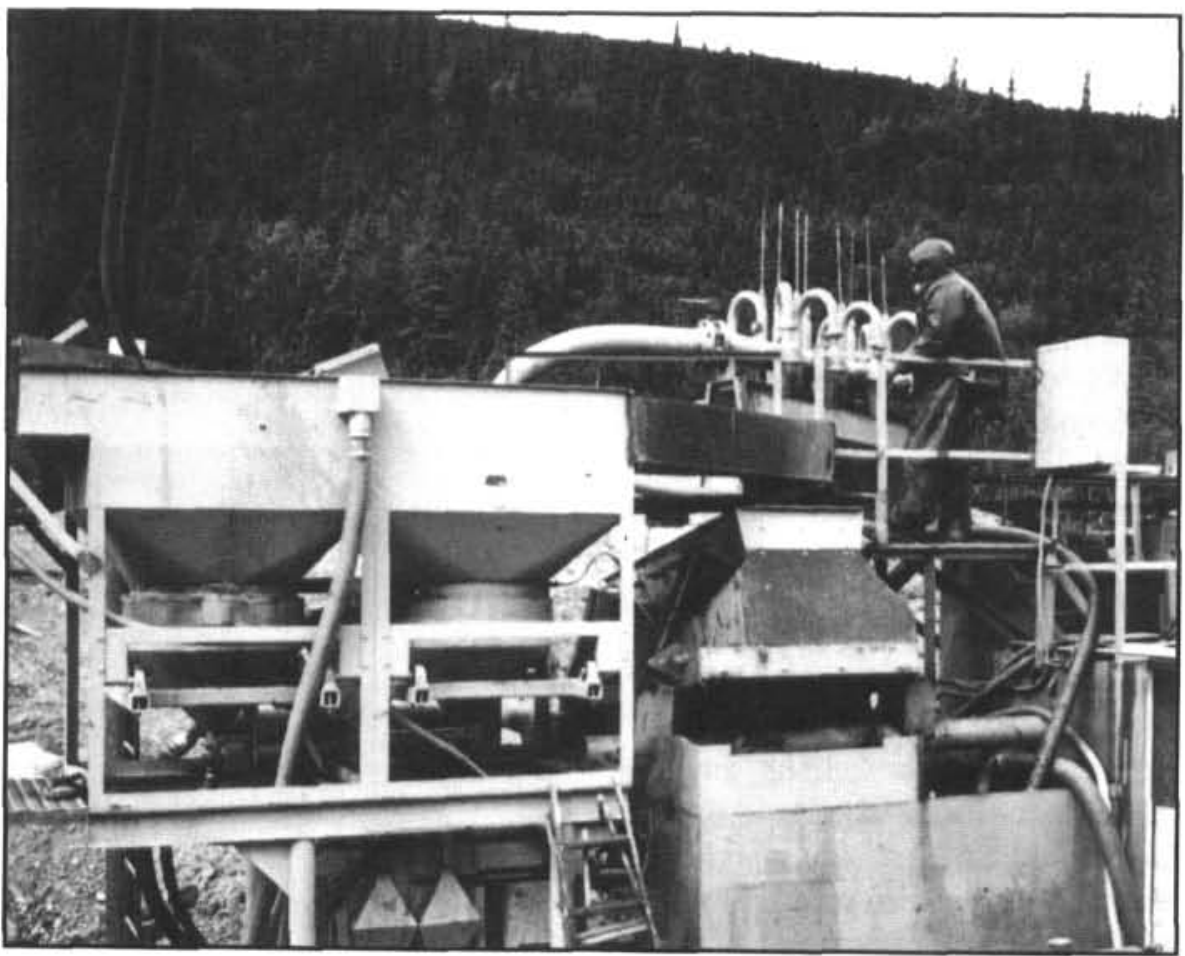

by Alaska Placer Development to contain waste water and mine effluent.

Judging from DGGS questionnaire returns and other state records, placer mine activity in the EurekaTofty and Rampart districts grew by more than 60 percent, from nine operations in 1989 to 15 in 1990. Alaska Placer Development ,Inc., which mines pay in the Livengood district, started a new placer gold mine on American Creek in the Eureka district east of Manley Hot Springs.

\section{Shoreham Resources worked} Cache Creek in the Tofty district and was one of the largest placer mines west of the Fairbanks district within the eastern interior. The company recovered 1,074 oz of gold, 208 oz of silver and 2,600 pounds of tin from $26,000 \mathrm{yd}^{3}$ of processed pay. Mechanical difficulties and excessive overburden, coupled with low gold prices, reduced profitability at the mine.

Other smaller placer mines worked include Robert Roberts on Skookum Creek; Iditarod musher Ric Swenson on Doric Creek; Orval McCormach on both American and Eureka Creeks; longtime mine operator Mike Krenzke on Eureka Creek; Jim Wood on Little Boulder Creek; Salter and Associates on Joe Bush Creek; Delima Placers, Inc. on both Colorado and American Creeks; Harold Bergman on both Cache and Sullivan Creeks; Vern Petefish on Little Boulder Creek; and Anna Russell on Trail Creek. Longtime Rampart district miner John Shilling sluiced pay on Slate Creek in the Rampart district, and Frank Wilford worked bench gravels on Hoosier Creek in the same district.

The historic Fortymile district, Alaska's oldest placer gold mining region, saw an even larger increase of mine activities than in the previous two years. The number of placer mines increased from nine in 1988, to 16 in 1989, to 28 in 1990. 
However, most outfits are small mechanized sluicing plants or scaled-up suction dredges normally associated with recreational mining or ground testing.

Mike Buzby worked on ground leased from the Alaska Gold Company on Chicken Creek; Black Velvet Mining Company mined on the South Fork of Fortymile River; Dome Creek Mining and Development sluiced on Dome Creek; Leo Regner worked Lillywig Creek; and Charles Hammond won gold from 45-Pup. Smaller operations include: Mike Chambliss and Clyde Baldwin on South Fork Fortymile River; Hank and Sons on Lost Chicken Creek; Maxwell Mine and Exploration and Al Ruddick on Canyon Creek; Ken Wise on Mosquito Fork, Fortymile River; Dave Moss on Liberty Creek; Freedom Mining and Exploration on Robinson Creek; Richard Goodson on Fortymile River; Hayden Exploration and Mining and Maxwell Exploration and Mining (separate operations) on Baby Creek; Lone Spruce Mining on Squaw Creek; Frank Lockner on 60 Mile River; Joe Trudeau on Jefferson Creek; Franklin O'Donnell on Moose Creek; Mike Williams on Kenyon Creek (a new operator); Steve Bills on O'Brien Creek; and Judd Edgerton on Robinson Creek.

Suction-dredge operators on the Fortymile River system included the following: Ostler Mining, Tom Erickson, John Roop, and Wesley Devore.

Dave Likins operated his New Zealand-type floating and washing plant on the Fortymile River. This plant is essentially a scaled-down recovery system similar to that used in bucket-line stacker dredges. Because the plant moves in its own pond, the mine simultaneously reclaims land while moving down the paystreak. The operation may have gained some undeserved notoriety when concerned environ-

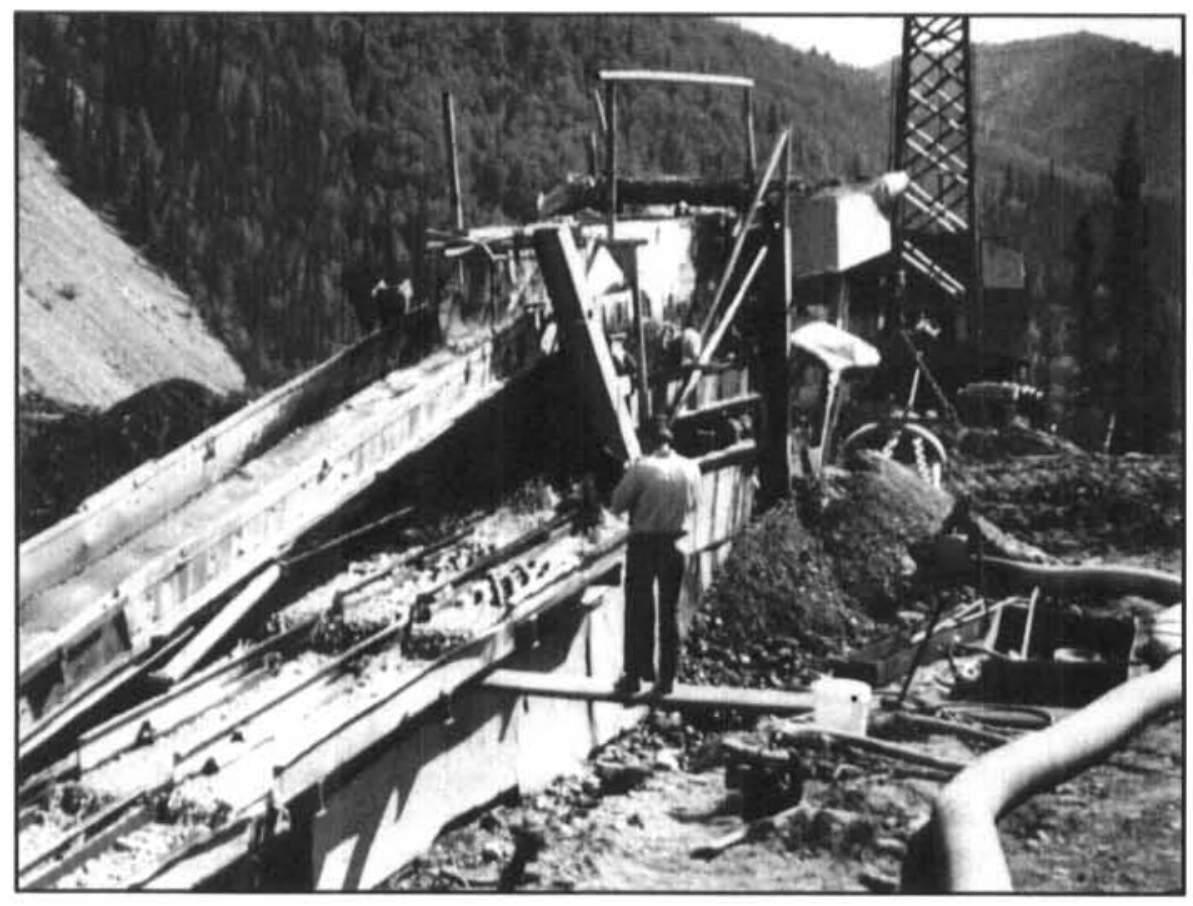

mental activists characterized the operation as a large, bucket-line stacker dredge, instead of the relatively small operation that it actually is. Controversy continues to surface in news media reports of any mine activities along the Fortymile River, partly because of its 1980 designation as a National Wild and Scenic River.

Growth in the placer mining industry was notable in the camps along the north flank of the Alaska Range. In the Bonnifield district east of Healy, the number of active placer mines increased from nine in 1989 to 12 in 1990 in spite of low gold prices (fig. 36). Alaska Unlimited,Inc., again operated the largest placer mine in the Bonnifield district on Gold King Creek. Placer gold from this property is believed to be derived from Tertiary-aged Nenana Gravel or the Nenana coal-bearing group. Gypsy Luck Mining Company worked a smaller paystreak at Walker Creek near Gold King Creek. Small-to medium-sized operators working pay throughout the district include: $P$ \& P Mining on Newman Creek; Barney Harrod
Figure 36. During the 1990 production season, Alaska's placer mines produced an average of $892 \mathrm{oz}$ of gold. This typical operation uses a dragline to collect the grave/ which goes through the washing plant. Once production is completed, the dragline will be used to recontour the mine site and reclaim the area. (Photo by Bruce Campbell)

on Bonnifield Creek; Old Yeller Mining and Kerry Knapp on Totatlanika River; Tom Faa on Moose Creek; The Four Stewards on Iron Creek; Glenn Parr on Walker Creek; the Annabelle Mine (Jim Roland) on Moose Creek; Tommy Van, Inc., on Flat Creek; Fred Cook on Portage Creek (another gold placer with a Tertiary sedimentary source); and Jackson Mining Company on Totatlanika River.

Some areas in the Alaska Range that have been dormant for years were tackled by small enterprising mining firms. Tok Gold and Exploration mined a small cut on Tok River near Stibnite Creek, an area better known for base metal deposits. In the Delta River district, Law Iosua and MVM Associates were 
active on Rainy Creek, a placer stream known to contain platinum as well as gold. Richard Knutson processed pay on Broxson Gulch, another stream west of Rainy Creek known to contain platinum. Big Delta miner David Jensen produced gold from both July and McCumber Creeks near the Granite Mountains.

\section{Southcentral Region}

The cessation of mine activities at Cambior's Valdez Creek Mine from October 1989 to August 1990 is clearly reflected in production statistics of the southcentral region, which saw the largest statewide drop in production of gold. Our region-wide estimated production of $16,670 \mathrm{oz}$ in 1990 is only one fifth of the $73,100 \mathrm{oz}$ produced in 1989. Employment also dropped from 280 to 160 , a decline of about 60 percent. However the decision to reopen the Valdez Creek Mine by its new operator, Cambior Mines, is good news for the region. Since operations began in 1984, the Valdez Creek Mine was the largest of Alaska's many gold producers for five of the last six years (Reger and Bundtzen, 1990). Previous mine production by Valdez Creek Mining Company concentrated on the development of several deeply buried paleo-channels, ancestral to modern day Valdez Creek.

Gold production began in October from the old hydraulic pit or Dry Creek Cut, which is, in part, an extension of the Tammany Channel system previously mined by both open-cut and underground methods. An estimated $11,700 \mathrm{oz}$ of placer gold $(8,031 \mathrm{oz}$ refined) were recovered from $138,000 \mathrm{yd}^{3}$ of processed pay during a five-week period. During 1990 Cambior concentrated on an expensive rerouting of Valdez Creek required by the Alaska Department of Fish and Game (ADF\&G). The diversion is necessitated by the convergence of the upper pay channels and the present water course of Valdez

Creek. Fisheries in the main stream course are to be protected before ADF\&G will issue the required permits. Cambior Mines employed 160-to-170 workers during production and stream diversion, and expect to produce substantial quantities of gold when full production is resumed in 1991.

Other much smaller placer mines worked pay in the Valdez Creek district. They include: Crooked Dog Mining on Grogg Creek, Howard McWilliams on Johns Creek, and Broad Pass Mining on Squaw Creek.

The Chistochina level of activity was about the same as in 1989. Hoffman Mining, with a crew of four, recovered gold, platinum, and silver from their Middle Fork Mine on the Chistochina River. George Livermore and William Beerman maintained production from mines on Ruby Gulch and Slate Creek, tributaries to Chistochina River.

The Willow Creek district supported three small operations: the Mrak placer mine and Magnum Resources International on Willow Creek (separate mines), and Lonesome Mining Company on the Little Susitna River.

The historic Cache Creek of Kahiltna district contains 23 individual Alaska Placer Mining Application Permits (APMA) mine sites; however, many of these remained dormant during the 1990 season. Most mines used small mechanized test plants suitable for fine gold recovery. Ed Ellis manually mined gold and platinum bearing pay on the Golden Bar Group-a river bar placer deposit-many miles away from presumed lode sources in the upper Cache Creek drainage. Jim Watkins mined a similar paystreak on nearby Falls Creek. Arne Murto continued to recover small amounts of platinum and gold from Martin Creek, in the upper Kahiltna River drainage about $25 \mathrm{mi}$ southeast of Puntilla Lake. Martin Herzog worked Cache Creek proper, as he has for a number of years.

Mining on the Kenai Peninsula was almost entirely confined to either recreational suction dredges or tourist-oriented mechanized plants. Outsider Mining Company (John Trautner) mined the Wagner Group near Girdwood by hand and with a suction dredge. Cynthia Toohey worked various locations throughout the old Hope district using minimal equipment. Wallace Saline mined Canyon Creek with a suction dredge.

The Nelchina district remained dormant for most of the season. Most mine questionnaire respondents indicated that assessment work was their principal activity.

\section{Southwestern Alaska}

The southwestern region includes such historic mining regions as the Innoko, Iditarod, Aniak (Nyac), and Goodnews Bay districts, which have accounted for about 10 percent of Alaska's gold and most of its mercury and platinum production. Questionnaires and state records indicate that $14,400 \mathrm{oz}$ of gold and modest amounts of tungsten and mercury were recovered from the region's 26 placer mines. These figures indicate activity at about the same level as in 1989. Twenty-six mining companies employed 100 people throughout the area.

Nyac Mining Company operated the region's largest placer mine at the head of Bear Creek in the Nyac district, about 35 mi south of Aniak, on the lower Kuskokwim River. About 20 people at Nyac mined several hundred thousand yards of pay from a shallow bedrock placer. The company controls claims throughout the Nyac district and previously mined gold with a $5 \mathrm{ft}^{3}$ bucket-line dredge in upper Bear Creek. About 30 percent of the mechanics and support staff employed by Nyac Mining Com- 
pany live in the village of Crooked Creek along the Kuskokwim River. These native Alaskans got their start in Alaska's mining industry working on a joint-venture exploration project managed by Westgold and Calista Native Corporation at the Donlin Creek hardrock-gold prospect northeast of Nyac.

Traditional long-time placer mining companies worked ground in the Innoko and Iditarod districts. Magnuson Mining Company worked patented claims in the Ganes Creek drainage, and explored the old Independence hardrock mine at the head of Carter Creek. The Golden Horn Mining Company John Miscovich family operation) leased ground to R.R. Hensler, Inc., of California who operated on Otter Creek near Discovery Camp. This project, which re-mined dredge tailings with front-end loaders and a backhoe, was discontinued late in the season due to poor gold recovery. Richard Wilmarth took out a small cut while constructing a bedrock drain at the lower end of the paystreak on Chicken Creek in the Iditarod district. Results indicated that it was a worthwhile activity to sluice the development project's wasterock. Julian Creek Mining Company again mined the seemingly endless paystreak on Julian Creek in the George River drainage. This paystreak was thought to have been exhausted years ago.

L.E. Wyrick and family expanded their operation on Granite Creek, also in the George River, and recovered substantial coarse gold from shallow pay zones near the head of the pup. The longactive Lyman Resources of Alaska did not mine their Donlin Creek placer deposits, but instead concentrated on construction of a new washing plant and exploratory sampling. Flat Creek Placers (Fullerton family operation) continued to conduct mining operations on upper Flat Creek in the Iditarod district, but suffered a setback with the death of Richard Fullerton, who mined with brother John for more than 50 years in western Alaska. John O'Carroll mined on Spruce Creek bench, but had a disappointing year compared with previous seasons. Allan (Eep) Anderson worked old dragline tailings and some virgin ground on Yankee Creek west of Takotna. Paul Sayer both explored and mined Little and Ester Creeks near Ophir. R \& W Mining resumed work on Ophir Creek which had been dormant for several years. Alvin Agoff was busy on Prince Creek south of Flat; this small venture continued to encounter pay under coarse colluvium at the base of Chicken Mountain.

There was a scattering of placer mines throughout remote regions of southwest Alaska-backwater areas within a backwater of Alaska. Dave Penz mined rich pay on Buster Creek near Russian Mission on the lower Yukon River. Fred Noden worked a relatively new operation on a small scale on Chanuk Creek on the Mulchatna River drainage north of Lake Clark. Richard Busk mined on ground formerly worked by Terry and Victoria Gill on Scynneva Creek in the Bonanza Hills also north of Lake Clark. LBMB Mining Company worked a small cut on Murray Gulch and New York Creeks south of the Horn Mountains along the Kuskokwim River. These two creeks were the sites of some of the earliest discoveries of gold in the Kuskokwim River area. Scott Greger activated the Taylor Creek placer mine in the Taylor Mountains south of Sleetmute. The mine had been dormant for some years. Holitna Basin Mining completed some testing of placer ground on 47 Creek also south of Sleetmute. The mine had been dormant for some years. Holitna Basin Mining com- pleted some testing of placer ground on 47-Creek also south of Sleetmute, but did not recover a commercial quantity of gold.

\section{Southeastern Region}

Miners in the panhandle are pleased with the success of Kennecott Greens Creek Mining Company (Greens Creek Mine) on Admiralty Island. The Greens Creek deposit is located approximately $18 \mathrm{mi}$ southwest of Juneau in a non-wilderness section of Admi ralty Island National Monument. The exploited ore bodies are considered to be volcanogenic massive sulfide deposits in folded metasedimentary rocks of the Cannery Formation of Late Triassic age (Berg, 1984). Three main ore bodies have been identified as the north, central, and south zones. The individual ore zones are 200 to $700 \mathrm{ft}$ wide, 1,200 to $2,000 \mathrm{ft}$ long, and 6 to $80 \mathrm{ft}$ thick. The ore bodies contain significant amounts of silver, lead, zinc, gold, barium, and copper. The first four of these commodities are commercially recovered.

During 1990 Greens Creek Mine milled 382,574 tons for a year-round average of 1,050 tons/ day, and produced $7,636,501$ oz of silver, 38,103 oz of gold, $33,457,084$ pounds of lead and $74,006,086$ pounds of zinc contained in concentrates. Greens Creek Mine was the nation's largest silver mine for the second consecutive year. The company resolved mill-loss problems encountered in its first (1989) year of operation by a flotation redesign and finer grinding methods. Puzzling underground dust explosions in 1989 were controlled by water saturation at the working face, although some minor dust explosions did occur in 1990.

Greens Creek employed 265 workers year-round during mine 
operations and added about $\$ 20$ million to the economy of Juneau in salaries, goods, and services. Most employees live in Juneau and are transported daily aboard the catamaran Alaska Dream. An extensive exploration and development program is ongoing on the property. Reserve estimates at the commencement of mine activities were about $4.7 \mathrm{mil}$ lion tons of about 24 oz/ton silver,
$0.18 \mathrm{oz} /$ ton gold, 9.7 percent zinc, and 3.9 percent lead. Recovered (not in-place) grades during 1990 were $19.9 \mathrm{oz} /$ ton silver, $0.09 \mathrm{oz} /$ ton gold, 4.37 percent lead, and 9.7 percent zinc.

Small placer mines provided the remaining metal production in the southeastern region. Carl Glanville worked strandline deposits along the beachline near Yakataga at a daily rate of about
$30 \mathrm{yd}^{3}$. Snow Lion Mining Company (Jerry Fabrizio) worked claims on Porcupine Creek near Haines, but on scales similar to Glanville's Yakataga operation. Andrew Moritz, Jr. tested strandline deposits near Mt. Fairweather north of Glacier Bay National Park, but did not achieve commercial production in 1990.

\section{INDUSTRIAL MINERALS}

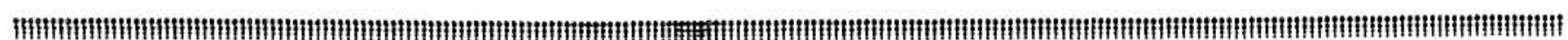

\section{INTRODUCTION}

The value of industrial mineral production in 1990 was $\$ 62.9$ million, a 2.4 percent increase from the $\$ 61.4$ million produced in 1989 (table 7). Sand, gravel, and stone made nearly equal gains from the previous year, mainly because of the improved construction climate in the Fairbanks and Anchorage urban areas (table 10). The industrial mineral industry in Alaska depends on in-state industry and government construction since virtually all commodities are used in
Alaska and are not exported. Results from 34 questionnaires and 15 additional phone calls indicate that most sand, gravel, and stone producers continue to be frustrated by generally weak demand for their products and increasing regulatory restrictions implemented by local, state, and federal agencies. Industrial mineral quarries have been included in recent legislation passed by the Alaska Legislature that requires rents, royalties, and reclamation requirements. Five companies announced that they ceased operation in 1990 because of the overall unfavorable economic and regulatory climate.

\section{Northern Region}

Industrial minerals in the northern region are mainly used to build the infrastructure of Alaska's North Slope petroleum fields. More recently, they have been used also at the Red Dog zinc mine north of Kotzebue. These two sites have

\begin{tabular}{|c|c|c|c|c|c|}
\hline \multicolumn{6}{|c|}{ Table 10. Reported sand and gravel production and industry employment in Alaska by region, 1990} \\
\hline Region & $\begin{array}{l}\text { Companies } \\
\text { reporting^ }\end{array}$ & Tons & $\begin{array}{l}\text { Estimated } \\
\text { unit value }\end{array}$ & $\begin{array}{l}\text { Total } \\
\text { value }\end{array}$ & $\begin{array}{l}\text { Number } \\
\text { of } \\
\text { employees }\end{array}$ \\
\hline Northern & 3 & $1,525,000$ & $\$ 4.00$ & $\$ 6,100,000$ & 130 \\
\hline Western & 2 & 818,000 & $\$ 4.00$ & $3,272,000$ & 25 \\
\hline Eastern/Interior & 14 & $4,975,500$ & $\$ 2.40$ & $12,438,750$ & 153 \\
\hline Southwestern & 1 & 100,000 & $\$ 4.00$ & 400,000 & 7 \\
\hline Southcentral & 15 & $5,345,000$ & $\$ 2.35$ & $12,560,750$ & 160 \\
\hline Alaska Peninsula & 8 & 850,000 & $\$ 3.00$ & $2,550,000$ & 90 \\
\hline Southeastern & 6 & $1,400,000$ & $\$ 2.50$ & $3,500,000$ & 80 \\
\hline TOTAL & $\overline{49}$ & $\begin{array}{l}15,013,500 \\
(13,617,000 \\
\text { tonnes) }\end{array}$ & & $\overline{\$ 40,821,500}$ & $\overline{645}$ \\
\hline & 5 phone $\mathrm{c}$ & responses. & & & \\
\hline
\end{tabular}


used about 1.5 million tons of sand and gravel. B.P. Exploration used 130,200 tons for maintenance and construction projects in western operating area of the Prudhoe Bay unit and at the Duck Island unit. ARCO Alaska reported mainly maintenance activities for drill sites and airport trench lines; approximately 100,000 tons of gravel were mined from several Kuparuk pit sites. The U.S. Bureau of Land Management permitted extraction of about 400,000 tons of gravel at 30 sites along the Dalton Highway for pipeline and road repairs. All of the remaining 900,000 tons of material were used in stream diversion, tailings pond repair, and road repair at the Red Dog project. An additional 600,000 tons of crushed stone was used as filler for various construction uses in the area. NANA Corporation continued to extract and market jade from its jade deposits in the Ambler River area. The late Ivan Stewart formerly mined and stockpiled raw jade for future processing (fig. 37).

\section{Western Region}

Tidemark Corporation mined 98,000 tons of gravel with an estimated value of $\$ 452,000$ to repair and improve the Teller airport on the western Seward Peninsula. The Alaska Department of Transportation and Public Facilities (DOT\&PF) used about 720,000 tons of gravel and compaction sand to repair various roads on the Seward Peninsula--a number of pits and vendors were involved in the repairs. An estimated 40,000 tons of stone were also used to repair the Nome seawall and at the Teller project.

\section{Eastern Interior Region}

The eastern interior region was again bouyed by large construction projects aimed at modernization of thoroughfare roads in the Fairbanks area and fundamental repair work along the Alaska Highway. Fourteen companies and government agencies reported that 4.98 million tons of gravel and sand worth $\$ 12.4$ million were quarried throughout the area. The largest single project was the Geist Road Extension, which is designed to alleviate traffic congestion in west Fairbanks. Earthmovers Inc. was prime contractor for the job. Fairbanks Sand and Gravel mined 183,000 tons of sand and gravel from the floodplain of the Tanana River using a floating clamshell dredge. A crew of 11 operate the plant. R.B. Gravel Inc. recovered about 500 tons of mine tailings from their gold mine on Ready Bullion Creek for local private road jobs. Douglas Management mined 20,000 tons from their Peger Lake pit for contract work in the Fairbanks area. Shultz Excavating continued to be frustrated over an access dispute through Fort Wainwright to their pit sites. McPeak Sand and Gravel worked with Arctic-Redimix on several gravel construction needs.

DOT\&PF reported eastern interior region use of sand and gravel at approximately 950,000 tons. This includes repair work on the Parks, Alaska and Dalton Highways within the eastern interior region, but could include some volume that may belong in the northern region of this report. The U.S. Bureau of Land Management permitted extraction of about 530,000 tons of gravel from 30 quarry sites mainly along the Dalton Highway from Fairbanks to Yukon River.

Yutan Construction Company reported that approximately 500,000 tons of basalt were quarried from their Browns Hill quarry off Badger road near Fairbanks. The company did not specify project or end product uses. Jim Caswell again mined and processed limestone from his Cantwell Quarry for

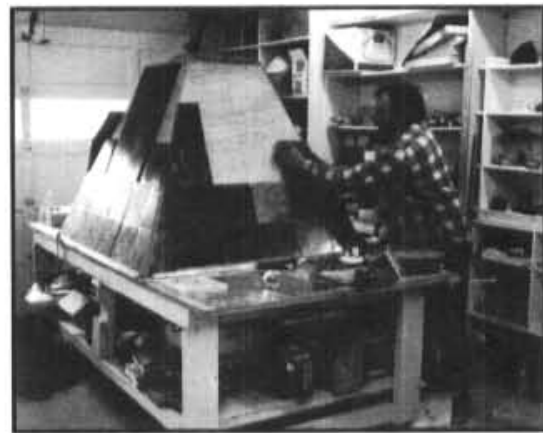

Figure 37. Jade from the Kobuk River in northwest Alaska is being crafted into a base for a memorial at the National Guard Armory near Eagle River. The jade was mined by Stewart's Photo, Inc. of Anchorage. (Photo by lim Prey)

instate agricultural markets. About 800 tons worth an estimated $\$ 60,000$ were realized from the operation. Although a small project, Caswell has demonstrated that local specialized needs can be met with Alaskan industrial mineral sources. Agricultural lime sells for up to $\$ 200 /$ ton and until recently was entirely derived from Lower 48 sources.

\section{Southcentral Region}

The strongest statewide showing of industrial mineral use came from the Anchorage-Matanuska Valley areas. The construction industry appears to be making a mild comeback, and road repairs by DOT\&PF increased in scope. For the first time in five years, the Alaska Railroad reported an increase in the amount of sand and gravel shipped from the PalmerWasilla area to Anchorage markets. The railroad estimated that $2,560,000$ tons were hauled in four unit trains daily throughout the construction season, compared with about 1,935,000 tons hauled in 1989. Road repair and completion of the new Seward Highway modernization program near Potters Marsh were some of the reasons 
cited for the increased use. Hermon Brothers mined gravel from their Schrock Pit in the Matanuska Valley. Spring Creek Gravel, Inc., supplied several screened gravel products for small projects throughout the Anchorage area from their Glenn Highway (Mile 204) pit. Lynn Sandvik reopened his Palmer pit because of improved market conditions in the Anchorage area. AAA Valley Gravel, Inc., remained one of the principal suppliers for gravel in the Wasilla area. Other smaller operators in the valley include Jim Cline's Enterprises and Cremer Services.

Several pits operated in the Kenai-Soldotna area. Longtime producer Waldo Coyle mined gravel from his homestead along Beaver Loop Road near Kenai. Jackson Construction quarried modest amounts of gravel, stone and sand for local uses in the Soldotna area, but complained that current permitting requirements limit their enterprise to small local markets. Fairwell Gravel also mines small amounts of gravel in the Soldotna area for local uses.

\section{Southwestern Regions}

Metco, Inc. mined 60,000 tons of gravel worth $\$ 63,000$ from the Metco River bar near Seward using a rubber-tired scraper. Calista Corporation reported that about 100,000 tons of gravel and sand were used in their region for road construction and erosion control along the Kuskokwim River. No other respondents indicated aggregate production in the large and remote southwestern region.

\section{Alaska Peninsula Region}

The normally quiet Alaska

Peninsula region reported a significant amount of industrial mineral use. Much of this was associated with the construction needs of an expanding commercial fishing onshore infrastructure. Westwood Foods contracted the Anchorage firm of Peratrovich, Nottingham and Drage to design and facilitate construction of a fish processing and surimi plant on Unalaska Island. The effort involved harbor reinforcement, foundation construction and road improvements that included the use of 90,000 tons of gravel and an undisclosed amount of rock. More stone and gravel use is planned in 1991 when construction begins on the $\$ 6.9$ million Unalaska Marine Center.

Moorecraft Construction was contracted by DOT\&PF to repair and maintain the King SalmonNaknek (Peninsula) Highway. Dutch Harbor Aggregate, Inc. quarried gravel from their South America pit for unspecified uses. Aleutian Materials (A.K. Construction Company) mined about 100,000 tons of gravel and sand on Kodiak Island for road and harbor maintenance. Likewise Brechan Enterprises leased the Bell Flats pit and mined gravel for use throughout the Kodiak Island Borough. Koniag, Inc., produced about 120,000 tons of riprap and pit rock in conjunction with logging operations on Afognak Island and at Womens Bay on Kodiak Island. The city of Kodiak mined about 700 tons of sand from Pillar Creek Beach for local municipal needs.

\section{Southeastern Region}

Our records, which are probably incomplete, show that 1.4 million tons of sand and gravel worth $\$ 3.5$ million and at least 1.2 million tons of rock worth $\$ 7$ million were quarried in the southeast region. As in previous years, the principal uses include maintenance of roads in the Juneau and Ketchikan municipal areas (sand and gravel) and logging road construction in the Tongass National Forest and on Native Corporation lands (stone).

Hildre Sand \& Gravel sold pitrun gravel worth $\$ 296,000$ from their Acme Pit near Juneau all for local needs. Another Juneau operation, Red Samm Construction, Inc., recovered an additional $\$ 200,000$ of gravel from their pit in Mendenhall Valley. Ritchie Transportation Company bailed pit-run sand and gravel from their Stikine River site, but reported frustration with ever-changing environmental stipulations. The City of Thorne Bay leased their rock quarry to Russell Construction Company, who mined about 8,000 tons of riprap worth $\$ 100,000$ for use on Prince of Wales Island. The city of Ketchikan excavated 20,000 tons of shot rock worth $\$ 100,000$ for use in the Ketchikan city limits. Ron Thomas leased gravel near Hyder for local construction uses. The U.S. Forest Service indicated that over 600,000 tons of sand and gravel and an equal amount of stone was used to construct logging access roads in the Tongass $\mathrm{Na}$ tional Forest. 


\section{COAL AND PEAT}

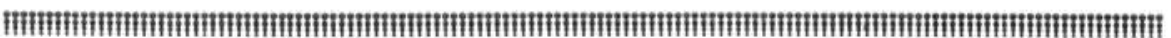

Usibelli Coal Mine, Inc., was again Alaska's only coal producer (fig. 38). During 1990, the company sold 1,576,000 short tons from the Usibelli Coal Mine to several interior markets and to the Korean Electric Power Company in Honam, South Korea, which bought about half of the coal. The 1990 year-end total is a record for the company, which first began expanding its market to overseas buyers in 1984 after supplying Alaskan power plants for 40 years with steam coal from the Nenana coalfield near Healy, Alaska (fig. 39). The coal is rated a subbituminous- $C$ with extremely low sulfur but high ash, factors that have contrasting marketability issues for the world's coal users.

Usibelli hopes to benefit from construction of a state-of-the-art mine-mouth power plant at Healy known as the Healy Clean Coal Project. The Alaska Industrial Development and Export Authority submitted a bid to the Federal Department of Energy two years ago to receive grant funding of up to $\$ 93$ million to build a 50 -megawatt-rated power plant by the late 1990s. This plant would employ the latest clean-coal burning technologies (Green, 1990a, b). Golden Valley Electric Association (GVEA), who will operate and maintain the plant and purchase power, began holding public meetings late in the year. Usibelli will provide the fuel. The Alaska Power Authority received the permit application too late in the year for construction approval. Various utility board hearings are scheduled for 1991.

\section{DRILLING ACTIVITY IN 1990}

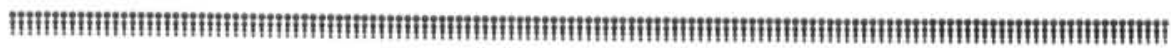

\section{INTRODUCTION}

Thirty-three companies reported significant drilling programs in 1990, 16 more than in 1989. Of these, 26 were hardrock programs, five were placer-drilling and two were for coal exploration or development. An additional seven placer mines reported some drilling, with a cumulative total of only $1,785 \mathrm{ft}$ in rotary, churn or auger holes.

Table 11 compares the amount of drilling reported in 1990 with that reported annually since 1982, and differentiates between drilling for placer, coal and hardrock exploration. Some of the drilling in each category is either development or production oriented, and is discussed in text. An additional $143,495 \mathrm{ft}$ of blast-hole drilling associated with coal mining at Healy has not been included. The total footage drilled in 1990, $963,080 \mathrm{ft}$, $(293,547 \mathrm{~m})$, was up 42 percent from the corresponding total in 1989, despite the significant drop in both placer and coal drilling. These declines were more than compensated for by the 167 percent increase in hardrock core-drilling and the 25 percent increase in hardrock reverse-circulation rotary drilling.

Table 12 shows the regional variations in drilling activity, and

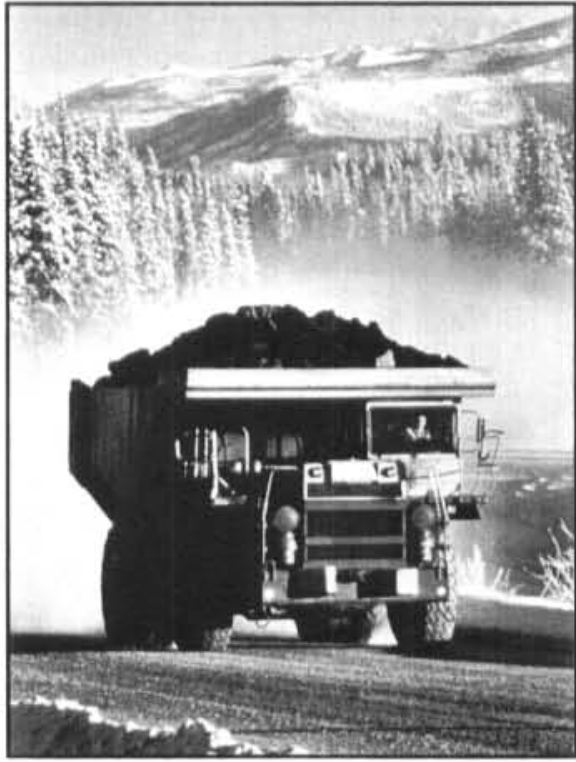

Figure 38. Usibelli Coal Mine operates year round at Healy, near Denali National Park. In 1990, Usibelli supplied coal to six interior power plants and exported roughly half of its 1.58 million tons of production to South Korea. As air quality standards in Pacific Rim nations grow more stringent, low sulphur coal from Usibelli and other Alaskan mines should be in greater demand. (Photo by Usibelli Coal Mine)

Figure 39. Part of the challenge of all-weather operations is equipment maintenance. In the Usibelli shop, mechanics service a 95ton Dresser Haulpak truck. This truck can carry more coal than a railroad car. (Photo by Usibelli Coal Mine)

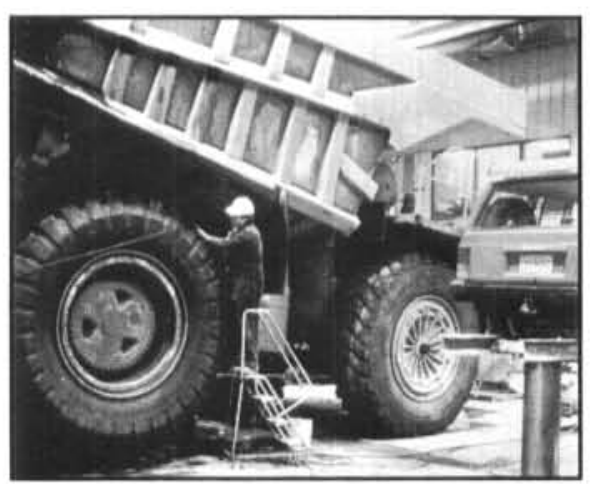




\begin{tabular}{|c|c|c|c|c|c|c|c|c|c|}
\hline \multicolumn{10}{|c|}{ Table 11. Drilling footage reported in Alaska, 1982-90 } \\
\hline & 1982 & 1983 & 1984 & 1985 & 1986 & 1987 & 1988 & 1989 & 1990 \\
\hline Placer exploration & 30,000 & 23,000 & 31,000 & 46,000 & 32,400 & 50,250 & 152,000 & 97,250 & 78,930 \\
\hline Placer thawfield & 94,000 & 30,000 & 98,000 & 34,000 & 227,000 & 130,000 & 300,000 & 210,000 & 105,000 \\
\hline Total & $\overline{124,000}$ & $\overline{53,000}$ & $\sqrt{29,000}$ & $\overline{80,000}$ & $\overline{259,400}$ & $\overline{180,250}$ & $\overline{452,000}$ & $\overline{307,250}$ & $\overline{183,930}$ \\
\hline Coal & 80,000 & 12,000 & 25,700 & 8,700 & 28,800 & 19,900 & 26,150 & 38,670 & 18,195 \\
\hline Total & $\overline{80,000}$ & $\overline{12,000}$ & $2 \overline{25,700}$ & $\overline{8,700}$ & $\overline{28,800}$ & $\overline{19,900}$ & $\overline{26,150}$ & $\overline{38,670}$ & $\overline{18,195}$ \\
\hline Hardrock (core) & -. & -. & -. & -. & -. & 95,600 & 223,630 & 242,440 & 648,600 \\
\hline Hardrock (rotary) & $-\cdot$ & -. & -. & $\cdots$ & $\cdots$ & 19,500 & 130,220 & 89,790 & 112,355 \\
\hline Total & $\overline{200,000}$ & $\overline{180,500}$ & $\overline{176,000}$ & $\overline{131,700}$ & $\overline{50,200}$ & $\overline{115,100}$ & $\overline{353,850}$ & $\overline{332,230}$ & $\overline{760,955}$ \\
\hline TOTAL (feet) & $\overline{404,000}$ & $\overline{245,500}$ & $\overline{330,700}$ & $\overline{220,400}$ & $3 \overline{38,400}$ & $\overline{315,250}$ & $\overline{832,000}$ & $\overline{678,170}$ & $\overline{963,080}$ \\
\hline TOTAL (meters) & $\overline{(123,139)}$ & $\overline{(74,828)}$ & $\overline{(100,797)}$ & $\overline{(67,177)}$ & $\overline{(103,144)}$ & $\overline{(96,088)}$ & $\overline{(253,593)}$ & $\overline{(206,700)}$ & $\overline{(293,547)}$ \\
\hline $\begin{array}{l}\triangle 143,495 \text { feet of bla } \\
\ldots \text { - Not specificall }\end{array}$ & $\begin{array}{l}\text { ole drilling } \\
\text { reported. P }\end{array}$ & included. & intinction & modr & noutin & t. & dhand & 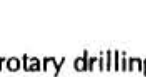 & footage. \\
\hline
\end{tabular}

Table 12. Drill footage by region in Alaska, 1990

\begin{tabular}{|c|c|c|c|c|c|c|c|c|}
\hline & Northern & Western & $\begin{array}{l}\text { Eastern } \\
\text { interior }\end{array}$ & $\begin{array}{l}\text { South- } \\
\text { central }\end{array}$ & $\begin{array}{l}\text { South- } \\
\text { western }\end{array}$ & $\begin{array}{c}\text { Alaska } \\
\text { Peninsula }\end{array}$ & $\begin{array}{l}\text { South- } \\
\text { eastern }\end{array}$ & TOTAL \\
\hline Placer exploration & 1,000 & 16,285 & 5,550 & 53,824 & 280 & -. & 1,991 & 78,930 \\
\hline Placer thawfield & -. & 105,000 & -. & - & -. & -. & .. & 105,000 \\
\hline Total & $\overline{1,000}$ & $\longdiv { 1 2 1 , 2 8 5 }$ & $\overline{5,550}$ & $\overline{53,824}$ & $\overline{280}$ & $\overline{-}$ & $\overline{1,991}$ & $\overline{183,930}$ \\
\hline Coal & -. & -. & 6,700 r & 11,495 & $\cdots$ & -. & -. & 18,195 \\
\hline Total & $\overline{-}$ & $\mp$ & $\overline{6,700}$ & $\overline{11,495}$ & $\cdots$ & $\cdots$ & $\cdots$ & $\overline{18,195}$ \\
\hline Hardrock core & 22,300 & 39,784 & 76,234 & 10,200 & 9,610 & 3,522 & 486,950 & 648,600 \\
\hline Hardrock rotary & . & 23,155 & 77,200 & 12,000 & -. & .. & .. & 112,355 \\
\hline Total & $\overline{22,300}$ & $\overline{62,939}$ & $\overline{153,434}$ & $\overline{22,200}$ & $\overline{9,610}$ & $\overline{3,522}$ & $\overline{486,950}$ & $\overline{760,955}$ \\
\hline TOTAL (feet) & $\overline{23,300}$ & $\overline{84,224}$ & $\overline{165,684}$ & $\overline{87,519}$ & $\overline{9,890}$ & $\overline{3,522}$ & $\overline{488,941}$ & $\overline{963,080}$ \\
\hline TOTAL (meters) & $(\overline{7,104)}$ & $\overline{(56,166)}$ & $\overline{(50,513)}$ & $\overline{(26,683)}$ & $\overline{(3,015)}$ & $\overline{(1,073)}$ & $(149,067)$ & $\overline{(293,547)}$ \\
\hline
\end{tabular}

-- No activity reported.

•Does not include 143,495 feet of blasthole drilling. 
table 13 is a listing of companies reporting significant drilling projects in Alaska in 1990.

One of the more important milestones in drilling activity was the 5,000-ft deep diamond-drill hole into the Treadwell structure at Juneau. As far as can be determined, this was the deepest drill-hole ever completed in hardrock mineral exploration in Alaska (fig. 40).

\section{PLACER DRILLING}

Placer drilling, following the trend of the last two years, declined by about 60 percent in 1990 to $183,930 \mathrm{ft}$ from the $307,250 \mathrm{ft}$ reported in 1989. Most of the decrease can be attributed to the halving of thawfield drilling.

As in 1989, most of the exploratory placer drilling was concentrated in southcentral Alaska, mainly in the vicinity of the Valdez Creek Mine, where Cambior Alaska, Inc., and Caprock Corporation, in partnership with Rowallen Mine Partnership, reported significant drill programs in 1990.

Only $105,000 \mathrm{ft}$ of thawfield drilling was reported at Nome by Alaska Gold Company, continuing the decline from a high of $300,000 \mathrm{ft}$ in 1988. This decrease represents changing ground conditions in the vicinity of the company's dredges.

In some ways thawfield drilling, which has strongly influenced the state's overall drill footage during the last three years, is more akin to development or production drilling than to exploration drilling.

\section{COAL DRILLING}

Usibelli Coal Mine, Inc., completed drilling about $6,300 \mathrm{ft}$ of reverse-circulation and auger holes in the Hoseanna Creek drainage, some for exploratory purposes and some for hydrology studies. An additional $143,495 \mathrm{ft}$ of air-rotary blast-holes were drilled for production purposes.
At the Wishbone Hill Mine, Idemitsu Alaska, Inc., drilled about $11,500 \mathrm{ft}$ of churn and core holes for development, geophysical logging and environmental baseline studies.

\section{HARDROCK DRILLING}

Reverse-circulation drilling increased 25 percent from the $89,790 \mathrm{ft}$ drilled in 1989 to $112,355 \mathrm{ft}$ in 1990 . Core drilling increased much more dramatically from $242,440 \mathrm{ft}$ in 1989 to $648,600 \mathrm{ft}$ in 1990, an increase of 167 percent, though $61,500 \mathrm{ft}$ of the total was for mine development, and $67,400 \mathrm{ft}$ was considered production drilling. Even discounting this $128,900 \mathrm{ft}$, the remaining $519,700 \mathrm{ft}$ of exploration core drilling is still an impressive 114 percent increase over the 1989 total.

Most of the increase can be attributed to advanced exploration at Echo Bay's A-J, Treadwell and Kensington projects at and near Juneau, and at Fairbanks Gold's Fort Knox project near Fairbanks. Continuing the trend of the last couple of years, about 82 percent of the hardrock exploration drilling in

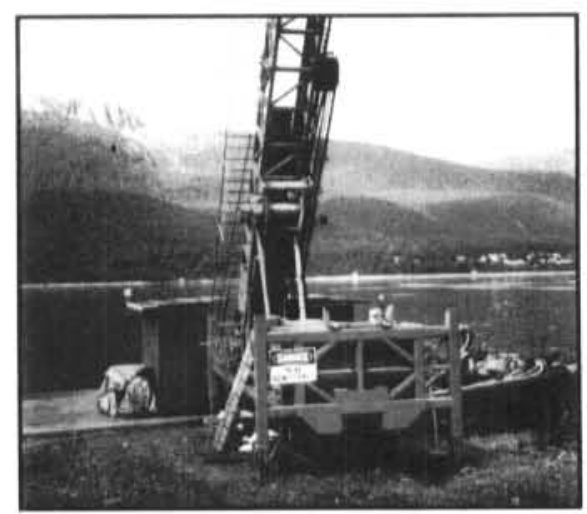

Figure 40. New technology is opening opportunities for Alaska. This 5,000-ft drill hole under Gastineau Channel near Juneau intercepted the Treadwell Mine structure far below the deepest workings. It is the deepest hardrock drill hole in the state and utilized the most sophisticated navigational drilling technology. At its prime, the Treadwell had many shafts drilled under the ocean. It ceased operations in 1922 when it was thought uneconomic to pump out its flooded tunnels. (Photo by R.C. Swainbanks)

Table 13. Companies reporting significant drilling projects, 1990

Alaska Gold

Alaska Placer Development AMAX

American Copper \& Nickel

ASARCO

Battle Mountain

BHP-Utah

Cambior Alaska

CanAlaska Resources

Caprock Corporation

Central Alaska Gold Co.

Citigold Alaska, Inc.

Cominco Exploration

Cominco Red Dog Mine

Delta Mining Co.

Echo Bay

Echo-Bay-A]

Echo Bay-Kensington
Fairbanks Gold

Flat Creek Mining

Great Basin

Hecla

Hunt Ware \& Proffett

Idemitsu Alaska

Kennecott Greens Creek

Kennecott Potatoe Mountain

Magnuson Mining

Moneta-Porcupine Mines

Pasminco

Placer Dome (U.S.), Inc.

Pulsar

Sphinx Mining

Tenneco Minerals

Usibelli Coal Mine

Vinta Exploration 
Alaska in 1990 was core drilling, with only 18 percent reverse-circulation. This compares with 71 percent in 1989 and 57 percent in 1988, and again reflects the advanced stage of many of the exploration projects.

Most of the drilling by Echo Bay at both the A-J and Kensington Mines was done to increase the reserve estimates. Pending issuance of permits, the Kensington is expected to begin development in 1992.

In 1990 Echo Bay Mines, Inc., drilled a deep hole that began near Thane on the east side of the Gastineau Channel. The 5,000-ft hole intersected the Treadwell structure on the west side of the channel. After drilling through more than $2,800 \mathrm{ft}$ of shearing below the channel, the pilot hole branched into four wedge holes to explore portions of the Treadwell structure. The "Navidrill" system guided the bit as far as $5,000 \mathrm{ft}$ from the collar of the hole on the east side of the channel.

Kennecott had a large exploratory drill program at and near the Greens Creek Mine in addition to $61,500 \mathrm{ft}$ of development drilling and
$47,400 \mathrm{ft}$ of production drilling. Placer Dome (U.S.) also had a significant exploratory drill project at its Jualin Mine near the Kensington $50 \mathrm{mi}$ north of Juneau.

In interior Alaska, Fairbanks Gold drilled $46,300 \mathrm{ft}$ of core hole and $62,600 \mathrm{ft}$ of reverse-circulation hole at their Fort Knox property and had smaller programs elsewhere. American Copper \& Nickel Company drilled $17,434 \mathrm{ft}$ of diamond-drill hole at the O'Dea Vein and on the Ethel Pit areas near the Grant Mine west of Fairbanks. They had several less ambitious programs elsewhere in the state. Citigold Alaska also operated a large and successful program at the Ryan Lode on Ester Dome.

In western Alaska, Central Alaska Gold Company operated an intensive drill program at the Nixon Fork Mine in preparation for a feasibility study while conducting several smaller programs throughout western and interior Alaska.

AMAX and ASARCO drilled prospects near Livengood, BHPUtah had a program on the Seward
Peninsula. Battle Mountain drilled prospects on the Aleutian Islands and in southwest Alaska.

CanAlaska drilled $12,000 \mathrm{ft}$ of reverse-circulation and $3,000 \mathrm{ft}$ of diamond-drill hole on its Rainbow Hill Project in southcentral Alaska near Valdez Creek.

Cominco Exploration drilled the Pebble Beach copper-gold porphyry near lliamna in southwest Alaska and had a smaller program in northern Alaska. About $20,000 \mathrm{ft}$ of production drilling was reported from the Red Dog Mine.

Hunt, Ware \& Proffett drilled about $7,000 \mathrm{ft}$ of core hole at the Johnson Prospect, a gold-zinccopper-lead prospect for which they are managing consultants.

Moneta Porcupine Mines, as part of a work commitment, drilled several holes in northern Alaska at the Lik Prospect. Pasminco had a modest program in the Kandik River area of the eastern interior in 1990.

Pulsar Resources (U.S.), Inc., a wholly owned subsidiary of Hyder Gold, Inc., had a 5,500 ft coredrilling program in the Hyder district in the extreme southeast of Alaska in 1990.

\section{METAL RECYCLING IN ALASKA, 1990}

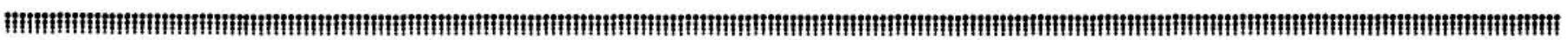

Metal recycling in Alaska suffered from depressed commodity prices and other complex market difficulties during the 1990 export season.

Estimated 1990 value of recycled metals is $\$ 3.56$ million, only 44 percent of the $\$ 8.13$ million credited in 1989. However, our 1990 volume and value estimates for commodities are influenced by both weaker commodity prices and fewer questionnaire responses. Only six of the 19 outlets known to be recycling metals provided specific production information. Obviously our volume and value estimates are conservative (table 14).
K \& K Recycling of Fairbanks and Anchorage Recycling Center (ARC) are responsible for about 70 percent of nonferrous metal output. Both reported difficulties in obtaining materials from scrap piles, and traditional landfill sources. Paper and glass recycling was nearly nonexistent and ARC's Fairbanks outlet, Sandy's Recycling, closed out glass recycling shipments due to a lack of markets.

However, lead recycling took almost a 200 percent leap in volume from 1989 levels (table 14). Battery Specialists, Inc., in Anchorage and Alaskan Battery Supply reported that their lead recycling businesses con- tinue to increase because of demand shown by west coast consignment buyers.

Alaska Metals Recycling (Anchorage) continued to operate its shredder and shipped roughly half the 12,500 tons of car bodies and structural steel credited to 1990 Alaskan production. Newell Recycling of San Antonio, Texas, reprocesses the Alaskan scrap onto saleable structural products.

Alaska Metals Recycling and the Alaska Support Industry Alliance dominated the ferrous scrap output. The Alliance is a consortium of North Slope petroleum companies that continued to manage the salvage operations of North Slope petroleum 
Table 14. Scrap metal and glass exports from Alaska, 1989-90

\begin{tabular}{|c|c|c|c|c|c|c|}
\hline \multirow{3}{*}{ Commodity } & \multicolumn{3}{|c|}{1989} & \multicolumn{3}{|c|}{1990} \\
\hline & \multicolumn{2}{|c|}{ Quantity } & \multirow[t]{2}{*}{ Value } & \multicolumn{2}{|c|}{ Quantify } & Value \\
\hline & (lbs) & $(\mathrm{kg})$ & & (lbs) & $(\mathrm{kg})$ & \\
\hline Copper-brass & $1,250,000$ & 567,000 & $\$ 1,437,500$ & 585,000 & 265,064 & $\$ 600,000$ \\
\hline Aluminum & $2,900,000$ & $1,315,440$ & $2,175,000$ & $1,500,000$ & 679,650 & 580,000 \\
\hline Stainless steel & $\ldots$ & . & $\ldots$ & 6,475 & 2,933 & 30,000 \\
\hline Car radiators & 275,000 & 162,880 & $1,100,000$ & -. & -. & - \\
\hline Zinc & .. & .. & .. & 40,000 & 18,124 & 20,000 \\
\hline Lead & $1,208,000$ & 547,488 & 507,360 & $3,600,000$ & $1,634,040$ & $1,260,000$ \\
\hline \multicolumn{7}{|l|}{ Non-ferrous } \\
\hline undistributed & $1,480,000$ & 671,328 & - & -. & .. & - \\
\hline Ferrous scrap & $48,000,000$ & $21,772,800$ & $2,900,000$ & $25,000,000$ & $11,327,500$ & $1,100,000$ \\
\hline Glass & 833,900 & 378,257 & 8,340 & -. & $\ldots$ & - \\
\hline TOTAL & & & $\overline{\$ 8,128,200}$ & & & $\$ 3,590,000$ \\
\hline .. - None reported. & & & & & & \\
\hline
\end{tabular}

Table 15. Selected companies that export scrap metal and glass from Alaska, $1989-90$

\section{Company}

Fairbanks

K\&K Recycling

Alum Recycling

Sandy's Recycling

Alaskan Battery Supply

\section{Anchorage}

Anchorage Recycling Center

Prescott Equipment

Battery Specialists Inc.

Alaska Metals recycling

Standard Steel and Metals

Staino Steel

M\&M Company

ARCO Alaska

Kenai-Soldotna

Tuttle Inc.

Hutton Enterprises

Juneau

E\&L Auto Body

Auke Bay Cans

North Tongass Salvage

Channel Sanitation

Ketchikan

Jim Church

\section{Commodities recycled}

Aluminum, copper, brass, ferrous scrap, nickel-cobalt alloys

Aluminum

Aluminum, glass, miscellaneous non-ferrous, radiators Lead-based batteries

Aluminum, glass, copper, brass, nickel-cobalt alloys Ferrous and non-ferrous scrap Lead-based batteries

Ferrous and non-ferrous scrap

Ferrous scrap

Ferrous and non-ferrous scrap

Ferrous scrap

Miscellaneous scrap

Miscellaneous scrap

Aluminum, lead-based batteries, auto bodies, radiators Aluminum, copper, brass, lead, zinc

Ferrous and non-ferrous scrap

Aluminum, lead-based batteries

Non-ferrous scrap, auto bodies
Stainless steel, miscellaneous scrap producers. During 1990, the consortium cleaned up several old distribution sites, including Service City, the original infrastructure center for development of the North Slope oil fields.

Workers at the Service City site removed 6,000 tons of ferrous scrap, $10,000 \mathrm{gal}$ of recyclable fuel, and $6,000 \mathrm{yd}^{3}$ of solid waste (table 15 ). 


\section{RENTS, ROYALTIES, AND RECLAMATION: Progress on the implementation of $6 \mathrm{i}$ legislation}

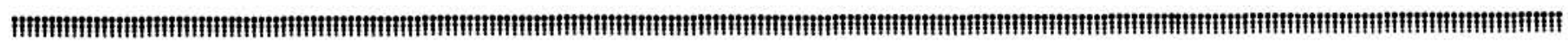

\section{BACKGROUND}

Prior to Alaska becoming a State in 1959, Congress enacted into public law the Alaska Statehood Act. Section 6 of the Act authorized Alaska to select 104.5 million acres of unreserved public land from the federal government in order to promote growth, development and self-sufficiency in the new State. The Statehood Act and Alaska's early legislative laws were enacted against the background of distinction that existed between the Federal Mining Law of 1872, the Mineral Lease Act of 1920, the School Lands Act of 1927 , and provisions in other statehood acts which granted lands for the generation of school revenue. The school lands act applies to school land grants which required the minerals of such lands to be retained subject to lease as the state legislature may direct. Rent and royalty received from minerals mined would be used to help support education. Section $6 i$ of Alaska's Statehood Act was patterned after the 1927 School Lands Act except the proceeds from rent and royalty received from leases were not required to be used for education only.

Section $6 i$ of the Alaska Statehood Act reads as follows: "All grants made or confirmed under this Act shall include mineral deposits. The grants of mineral lands to the State of Alaska under subsections (a) and (b) of this section are made upon the express conditions that all sales, grants, deeds, or patents for any of the mineral lands so granted shall be subject to and contain a reservation to the State of all of the minerals in the lands so sold, granted, deeded, or patented, together with the right to prospect for, mine, and remove the same. Mineral deposits in such lands shall be subject to lease by the State as the State legislature may direct: Provided, That any lands or minerals hereafter disposed of contrary to the provisions of this section shall be forfeited to the United States by appropriate proceedings instituted by the Attorney General for that purpose in the United States District Court for the District of Alaska."

Because of the distinction between the location-patent system embodied in the 1872 mining law, and mineral leasing under the 1920 Act, Alaskans wanted to retain this distinction that existed between mineral location and leasing in the Constitution which voters approved in 1956. Congress, however, wanted a universal "lease" requirement when it enacted section $6 i$ of the Statehood Act in 1958. Because of opposition to this universal leasing requirement in Alaska, Congress stated in the act that a special election be held in Alaska obtaining the voters consent to all provisions of the Statehood Act. The Statehood Act also stated that voter approval of the Act would result in the Constitution being amended accordingly. In August, 1958 , the people of Alaska voted in favor of the Act, and Alaska was admitted to the union as a state on January 3, 1959.

In the early years of statehood, the legislature and state officials overlooked the Constitutional amendments and did not interpret the universal lease requirement to apply to all of the (103 million acres) authorized to be selected by the state. Rather they interpreted it to apply only to lands where the state sold or otherwise disposed of the surface land, such as to local governments, etc., while retaining the minerals in the ground. In 1959, Alaska's first legislature implemented a law governing administration of lands owned by the new state. The 1959 legislation provided for the leasing of state land and the payment of rents and royalties for the extraction of coal, oil, gas, and other minerals governed by the Mineral Leasing Act of 1920. Other hardrock minerals such as gold and copper were made subject to discovery and location under Alaska mining laws which the legislature patterned after the Federal Mining Law of 1872.

In 1981, the commissioner of the Department of Natural Resources asked the state attorney general (AG) to review and analyze the meaning of section $6 i$. The AC issued an opinion that the leasing requirement in $6 i$ would apply to all lands known to be mineral-incharacter at the time that they were selected by the state. In 1982, the Alaska legislature amended the state's hardrock mining laws and authorized the commissioner to issue a production license to miners who wished to extract hardrock minerals. A production license was thought to be like a lease for purposes of section $6 i$.

In 1983, a coalition of environmental groups, Native village corporations, and fishing groups (Trustees for Alaska) filed a law suit in Superior Court stating that the State's hardrock mining 
laws violate section $6 i$ because the State does not receive rents and royalties in return for production licenses or leases and because the state defines the "lease" requirement to apply only to lands mineral in character when selected. The Superior Court ruled that coalition did not have standing to bring the law suit, since the coalition was not being harmed and had no personal stake or conflict with mineral resources being managed under existing laws. The Court held that since Section $6 i$ provides that the minerals are "subject to lease by the State as the State legislature may direct," the legislature had discretion to allow revenue from a lease (or production license) to be in the form of labor rather than cash, rents or royalties. The Trustees for Alaska appealed to the State Supreme Court and in May, 1987 the Court said that the coalition does have standing as tax payers to bring the law suit since they are interested in preserving to the State the economic value of these lands. The Supreme Court also said the Alaska hardrock mining laws are "indistinguishable" from a mineral location system and that the laws do not meet the leasing requirements of Section $6 i$ which mandates that the State receive rent or royalties for it's leases. The Court concluded that Congress granted Alaska the mineral rights with the intention that revenue received would help fund the new State government. The State appealed the State's Supreme Court decision to the U.S. Supreme Court. The U.S. Supreme Court, after considering the case, decided in October 1987 not to hear the case and rejected the State's legal position.

\section{IMPLEMENTATION}

In May of 1989, the Alaska State legislature passed Senate Bill

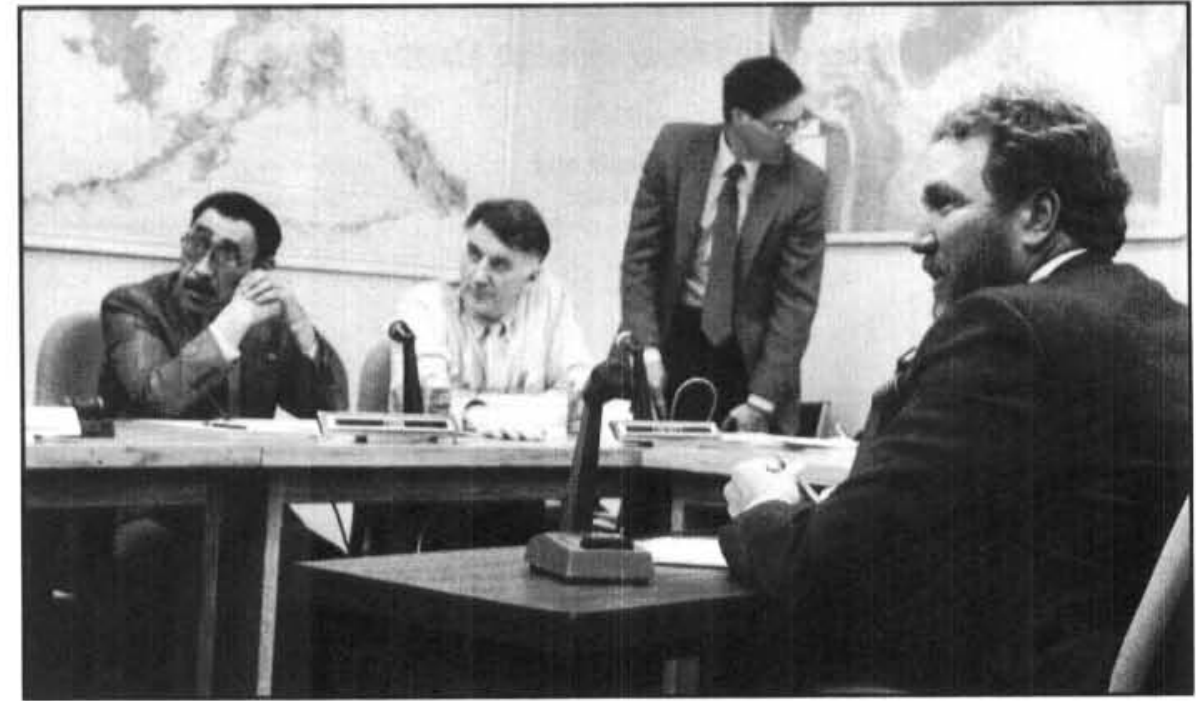

Figure 41. In the 1990 legislative session, new standards were established for reclamation of mining sites after the completion of production. Permitting Section Chief Judd Peterson, Division of Mining, reports on the completion of the proposed reclamation regulations to the 1991 House Resources Committee. Members of the committee shown are, left to right, Rep. Ivan M. Ivan, Rep. Pat Carney, an unidentified aide, and Peterson. (Photo by Cindy Roberts)

129 which was it's response to the 1987 Alaska Supreme Court decision in the $6 i$ law suit Trustees for Alaska vs. Alaska. This bill amended two State mining statutes (Annual Labor and Abandonment) and enacted three new statutes (Annual Rental, Production Royalty and Reclamation). The legislature further directed the Commissioner of the Department of Natural Resources to adopt regulations to implement these new laws. Reclamation was further amplified with the passage of Senate Bill 544 in May of 1990, which related to reclamation of land and water and replaced the reclamation statutes of Senate Bill 129. Each of the major aspects of the $6 i$ legislation, rents, royalties, and reclamation will be dealt with in turn.

\section{Rents}

The regulation changes which implemented the statutes in SB 129 were adopted and became effective on May 18, 1990. They dealt with mining, leasing, annual labor, annual rental, and claim abandon- ment. In summary, the holder of each mining claim, leasehold location, or mining lease on Stateowned land shall pay annual rental in advance for the right to continue to hold the mining claim, leasehold location, or mining lease. The annual rental amount is based on the number of years since the mining claim, leasehold location, or mining lease was first located. The progressive increase in rents is shown in table 16.

The rental for each year shall be credited against production royalty as it accrues for that year. A claim, lease hold location, or mining lease located on or before August 31, 1989, is considered to have been first located on August 31, 1989, for the purposes of determining the amount of rental under this section. The rental payment for the rental year that began at noon on September 1, 1989 , must have been paid on or before June 29,1990 , or within 90 days after the date of posting of the Notice of Location, which ever was later. Rental payment for each subsequent rental year is due on 


\begin{tabular}{|c|c|c|}
\hline \multicolumn{3}{|c|}{ Table 16. Schedule of mineral rents on Alaska state lands, 1990} \\
\hline $\begin{array}{l}\text { Number of years } \\
\text { since last located }\end{array}$ & $\begin{array}{c}\text { Rental amount per acre } \\
\text { per mining lease }\end{array}$ & $\begin{array}{l}\text { Rental amount for } \\
\text { each } 40 \text {-acre mining claim } \\
\text { or lease-hold location }\end{array}$ \\
\hline $0-5$ & \$ . .50 & s 20.00 \\
\hline 6-10 & $\$ 1.00$ & \$ 40.00 \\
\hline 11 or more & $\$ 2.50$ & $\$ 100.00$ \\
\hline
\end{tabular}

September 1 , and must be paid on or before November 30 . Included in the rental portion of the legislation was the option to pay annual labor in the amount of $\$ 100$ per claim prior to the completion of the labor year rather than actually performing the labor (table 17 gives a summary of the mineral revenues on State lands for the 1990 assessment year). Changes were made to the "abandonment" language to make it clear that failure to pay the rent or royalty is considered abandonment of the claim.

\section{Royalties}

Royalties are addressed in Senate Bill 129, (6i legislation) under section 38.05.212 Production Royalty, which states that the holder of a mining claim, leasehold location, or mining lease shall pay a three percent net royalty on all minerals produced from lands subject to claim, leasehold location, or mining lease. The "holder" is defined as (a) a person owning and operating a mining property, (b) a person owning a mining property and receiving lease or royalty payments based on production from the property, (c) a person leasing a mining property from another person and operating the property, or (d) a person possessing a mineral interest in a producing property including royalty, working or operating interest, net profits, overriding royalties, and production payments. In short, both the owner, the operator and any middle interests monetarily benefitting from a producing property need to pay production royalty. The regulations also state that annual rental due and paid under A.S.38.05.211 for a year shall be credited against the production royalty for that year.

Production royalty returns must be filed for each year after 1989 in which production occurs, or are sold, exchanged or otherwise disposed of. The production royalty returns are due every year on May 1 for the preceding calendar year and must be paid in currency. Payment "in kind" is not allowed. The first returns were due May 1, 1991 for the calendar year 1990, but have been delayed until November 30 , 1991. Upon request, most of the financial information contained in the production royalty returns will be kept confidential.

A holder of a mining claim, leasehold location, or mining lease who fails to file a production royalty return when due, or who pays no portion of the production royalty when due, is deemed to have abandoned to the State all rights acquired under that State mining claim, leasehold location, or mining lease. If a production royalty payment is deficit but is otherwise timely paid, the holder of the mining claim, leasehold location, or mining lease has 60 days to pay the deficiency plus interest or must pay within 30 days of the date of the notice of the minerals produced from State land

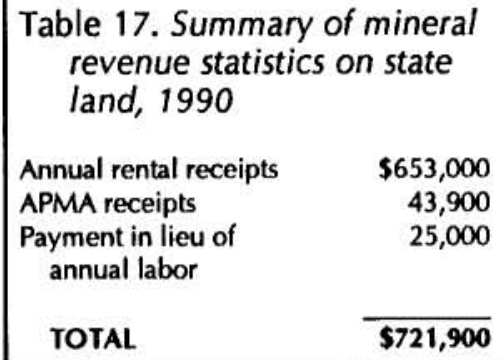

department's negative decision after protesting the deficiency.

In addition to deeming abandoned a mining claim, leasehold location, or mining lease, the division may file suit to collect a production royalty payment in the event of non-payment or deficiency payment of a production royalty payment, or failure to file a production royalty report when due.

\section{Reclamation}

Reclamation was specifically required by Senate Bill 129 (the $6 i$ legislation). This legislation stated that "the Commissioner shall require reclamation of State land from the effects of mining." These reclamation requirements were intended to spur comprehensive reclamation legislation in the next legislative session rather than to presently legislate. The 1990 legislature passed Senate Bill 544, The Reclamation Act, that required the Department of Natural Resources to prepare mining reclamation regulations and gave an effective date of the law as October 15, 1991 (fig. 41). Proposed reclamation regulations were to be submitted to the chairs of the Resource Committees of the 1991 legislature by DNR on January 15, 1991. This act establishes a new permit (a "reclamation permit") required of all mining operations in Alaska in addition to the existing approvals and operational permits required by state and federal agencies. 
The act contains the following provisions:

(1) Requires reclamation for all mining operations including sand and gravel and other materials.

(2) Extends reclamation requirements to state, federal, and private land; subject to a grant of authority for DNR to enter into cooperative management agreements with state and federal agencies.

(3) Requires submission and approval of a site-specific reclamation plan before mining may commence; subject to a small mine exemption for operators disturbing less than five acres at one location and having cumulative unreclaimed mined area of less than five acres at one location or gravel operators removing less than $50,000 \mathrm{yd}^{3}$ in one location and having cumulative disturbed area of less than five acres in one location.

(4) Reclamation bonding is made mandatory with a maximum bond ceiling of $\$ 750$ per acre; subject to the small mine exemption detailed in (3) above.

(5) Gives DNR the authority to establish and manage a statewide bonding pool.

(6) Establishes an "undue and unnecessary degradation" and returns to "stable condition" performance standards for reclamation. This parallels the BLM reclamation standard.

(7) Establishes two categories of mining operations in regard to the bonding and permitting of reclamation activity:

(a) Mines that mine more than five acres in any year or have a cumula- tive unreclaimed area

of more than five ares

at one location, or that remove greater than $50,000 \mathrm{yd}^{3}$ of material in any one year and there is a cumulative disturbed area of more than five acres at one location must be bonded and submit a reclamation plan for approval.

(b) Mines where less than five acres are mined at one location in any year and there is a cumulative unreclaimed mined area of less than five acres at one location; or where less than five acres and less than $50,000 \mathrm{yd}^{3}$ of gravel or other materials are removed at one location in any year and there is a cumulative disturbed area of less than five acres at one location do not need appproval of a preclamation plan and no bonding is required. This category of mines must simply

give notice of the reclamation measures they will take to comply with the reclamation performance standards of the regulations. No reclamation permit or approval is required. These mines must still obtain operational permits required and other state and federal authorities.

Reclamation is currently required for state lands through special stipulations in the Miscellaneous Land Use Permit (MLUP) and for Federal lands through either notice or plan of operations (figs, 42 and 43). Requirements under the reclamation regulations are similar in character to those currently required by both state and federal land managers. The main additional requirement is that of reclamation bonding. The primary tool for providing bonding is the establishment of a statewide bonding pool, and this pool is available to all operators regardless of land status. This pool should also satisfy $B L M$ 's pending bonding requirements for federal mining operations.

As of this writing, the legislature has instructed DNR to proceed with adopting final regulations through the standard public hearings process. In accordance with the act, reclamation regulations may not be adopted before October 15, 1991. Division of Mining is taking steps to implement the reclamation regulations to insure that the transition to the requirement of a new permit and subsequent additional paperwork is as smooth as possible. 


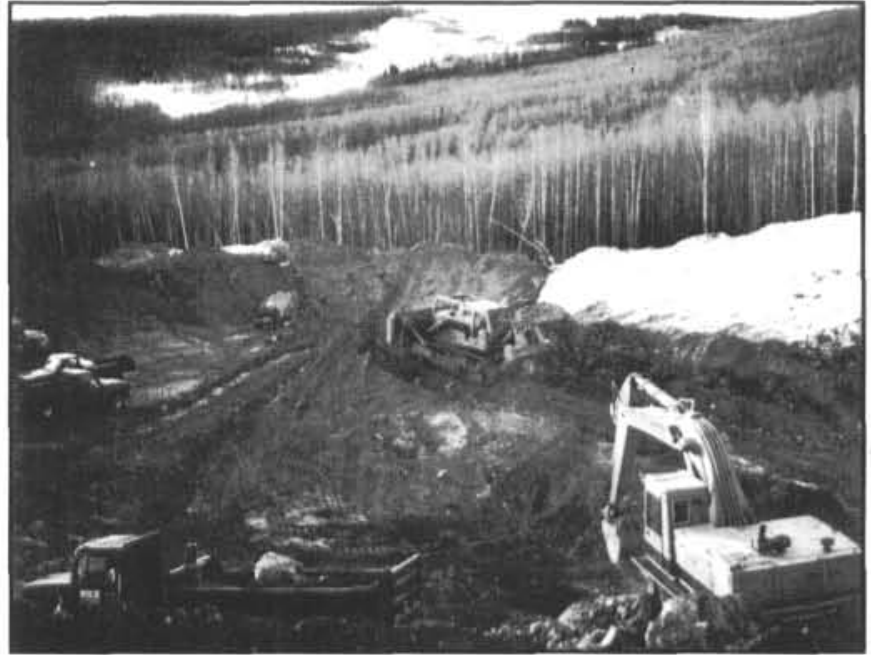

Figure 42. Mining projects in Alaska must plan for reclamation even as they are developed. In this 1988 photo, TriCon Mining Company is involved in an "open cut" hardrock gold operation on the south flank of Ester Dome, near Fairbanks. (Photo by T.K. Bundtzen)

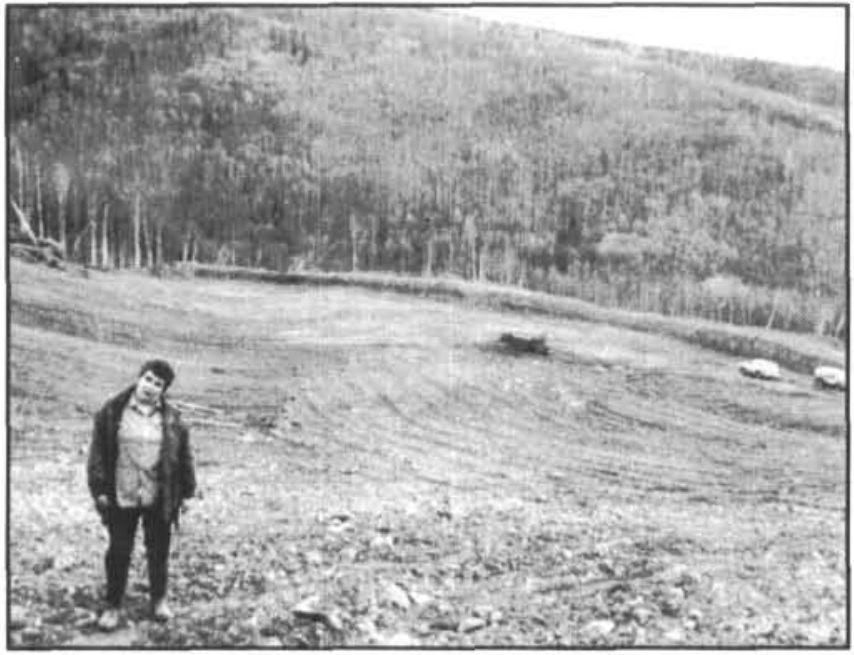

Figure 43. The same TriCon operation in this 1990 photo has been recontoured to minimize erosion and encourage revegetation. (Photo by John Wood)

\section{ILLUSTRATIONS}

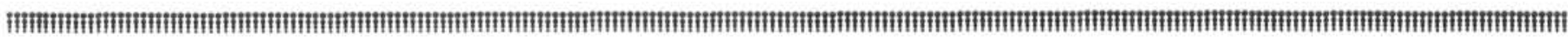

\section{FIGURES}

1. Graph of exploration expenditures reported, 1990

2. Graph of development expenditures reported, 1990

3. Graph of production expenditures reported, 1990

4. Graph of total production expenditures reported, 1990

5. Photograph of Commissioner Harold Heinze during discussion of the department-wide effort to complete selection of the final 20-million acres of the state's entitlement under the statehood act

6. Photograph of Dr. Earl Beistline, chairman of Alaska Mineral Commission, discussing pending legislation

7. Photograph of geologists from Magadan in the Soviet Far East inspecting Alaska Gold Company's dredge \#5 in Nome

8. Photograph of scientists from the U.S., Canada, and the USSR

9. Photograph of a student, a teacher, and a geologist using a geology study kit provided to schools by the Alaska Mineral and Energy Resource Fund (AMEREF)

10. Map showing regions of mining activity and selected mineral exploration projects

11. Graph of mineral exploration expenditures in Alaska, 1990
Page FIGURES (continued) Island near Fairbanks
12. Graph of the number of new claims, 1990

10

13. Graph of claim assessment work filed, 1990

10

14. Photograph of a technical specialist processing data from core drilling

15. Photograph of Director Sam Dunaway, Division of Mining, examining a core sample from Pebble Beach prospect

16 Photograph of a project near Dolomi on Prince of Wales

17. Photograph of drill rig and worker at the Fort Knox Project

16

18. Photograph of the Kensington Mine crew exploration on Lynn Canal in southeast Alaska

19. Photograph of miner operating a core drill at an underground exploration station of the $\mathrm{A}-\mathrm{f}$ mine

20. Map showing selected mineral development projects

21. Photograph of blaster loading explosive at the Greens Creek Mine on Admiralty Island

22. Photograph of DGGS hydrologists documenting naturally occurring erosion and sedimentation at Hoseanna Creek drainage at the Usibelli Coal Mine

Page

0

10


FIGURES (continued)

23. Photograph of water samples taken from the naturally turbid waters of Hoseanna Creek and from the clear discharge from the Usibelli settling pond

20

24. Map showing the location of principal goldmining camps, coal mines, and industrial mineral sites in Alaska, 1990

25. Graph of gold production in Alaska, $1880-1990$

26. Graph of sand and gravel production in Alaska, 1950-1990

27. Graph of coal production in Alaska, 1915-1990

28. Photograph of weather-proof structures that are part of the technological developments that make possible yearround operations above the Arctic Circle at the Red Dog Mine

29. Photograph of a NANA shareholder employed at the Red Dog Mine in northwest Alaska

30. Photograph of a staging area for the Chandalar Mine operation on Tobin Creek on the south side of the Brooks Range

31. Photograph of the BIMA offshore dredge

32. Photograph of a two-man placer gold operation at Democrat Bench

33. Photograph of father and son operators at the Dome Creek Drift Mine preparing to blast grave

34. Photograph of the owner and operator of a shot-loaded jig system at his placer operation

35. Photograph of Goldstream Exploration's spiral jig washing plant that was developed with a grant from the Alaska Science and Technology Foundation

36. Photograph of a typical placer mine operation using a dragline to mine the gravel that goes through the washing plant

37. Photograph of jade being crafted into a base for a memorial at the National Guard Armory in Eagle River

38. Photograph of equipment in operation at the Usibelli Coal Mine at Healy, near Denali National Park

39. Photograph of a 95-ton Dresser Haulpak truck at Usibelli Coal Mine

40. Photograph of the rig drilling a 5,000-foot hole under the Gastineau Channel near Juneau

41. Photograph of the Permitting Section Chief Judd Peterson of the Division of Mining reporting to the 1991 House Resources Committee

42. Photograph taken in 1988 of TriCon Mining Company's open-cut hardrock gold operation on Ester Dome near Fairbanks
FIGURES (continued)

Page

43. Photograph taken in 1990 of the same TriCon operation shown in figure 42 after reclamation contouring

44. Map showing significant copper, lead, zinc, $(+)$ silver, gold, and barite deposits in Alaska, 1990

45. Map showing locations of significant molybdenum-copper, and tin-tungsten ( + ) fluorite and beryllium deposits in Alaska, 1990

46. Map showing locations of significant gold, silver, platinum, and strategic mineral deposits in Alaska, 1990

TABLES

1. Total value of mineral industry in Alaska, 1990

2. Alaskan mine employment, $1988-90$

3. Soviet participants in 1990 AMA symposium

4. Reported exploration expenditures in Alaska by commodity, $1983-90$

5. Reported exploration expenditures and employment in Alaska by commodity and region, 1990

6. Reported mineral development expenditures and employment in Alaska by commodity and region, 1990

7. Reported mineral production in Alaska, 1988-90

8. Reported refined gold production, number of operators, and industry employment by region, 1989-90

9. Production costs for selected Alaskan placer mines, $1980-90$

10. Reported sand and gravel production and industry employment in Alaska by region, 1990

11. Drilling footage reported in Alaska, $1982-90$

13. Companies reporting significant drilling projects, 1990

14. Scrap metal and glass exports from Alaska, 1989-90

15. Selected companies that export scrap metal and glass from Alaska, 1989-90

16. Schedule of mineral rents on Alaska state lands, 1990

17. Summary of mineral revenue statistics on state land, 1990 


\section{REFERENCES}

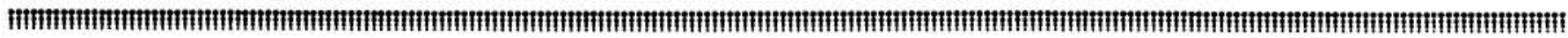

Berg, H.C., 1984, Regional geologic summary, metallogenesis, and mineral resources of southeastern Alaska: U.S. Geological Survey Open-file Report 84572: $298 \mathrm{p}$.

Gehrels, George, and Miller, L.D., Regional geology of the Juneau Gold Belt: Paper presented at conference of the Alaska Miners Association, Juneau Branch, Juneau, April 17-20, 1991

Goldfarb, R.J., Snee, L.W., Miller, L.D., and Newberry, R.J., Timing of gold deposition within the Juneau Gold Belt: Paper presented at the conference of the Alaska Miners
Association, Juneau Branch. Juneau, April 17-20, 1991.

Green, C.B., ed., 1990a, Summary: Usibelli Coal Beneficiation Project: Usibelli Coal Mine Information Brochure \#1, 6 p. 1990b, Healy Cogeneration Project: Usibelli Coal Mine Information Brochure \#2, $4 \mathrm{p}$. Kennedy, Alan, 1990, Red Dog zinclead mine-Alaska success for Cominco: in Mining Magazine, December 1990, ISSN03086631, p. 418-426.

Reger, R.D., and Bundtzen, T.K., 1990, Multiple glaciation and gold-placer formation, Valdez Creek Valley, western
Cleanwater Mountains, Alaska: Alaska Division of Geological and Geophysical Surveys Professional Report 107, 29 p., scale 1:63,360, 1 sheet.

Tunley, A.T., 1990, The Alaska minerals program is an educational alliance that works: in Journal of Geological Education, v. 38, p. 280. 
APPENDIX A

Total active claims and new claims staked in 1988, 1989, and 1990 (listed by quadrangle)

\begin{tabular}{|c|c|c|c|c|c|c|c|c|c|c|c|c|}
\hline \multirow[b]{3}{*}{ Quadrangle } & \multirow{2}{*}{\multicolumn{3}{|c|}{$\begin{array}{l}\text { Active claims } \\
\text { assessment work }\end{array}$}} & \multicolumn{6}{|c|}{ New claims staked } & \multirow{2}{*}{\multicolumn{3}{|c|}{$\begin{array}{l}\text { Total } \\
\text { active claims }\end{array}$}} \\
\hline & & & & & ederal & & & State & & & & \\
\hline & 1988 & 1989 & $\underline{1990}$ & 1988 & $\underline{1989}$ & 1990 & $\underline{1988}$ & $\underline{1989}$ & 1990 & 1988 & 1989 & $\underline{1990}$ \\
\hline Umiat & 0 & 0 & 0 & 0 & 0 & 0 & 0 & 0 & 0 & 0 & 0 & 0 \\
\hline Sagavanirktok & 0 & 0 & 0 & 1 & 0 & 0 & 0 & 0 & 1 & 1 & 0 & 0 \\
\hline Mt. Michelson & 0 & 0 & 0 & 0 & 0 & 0 & 0 & 0 & 0 & 0 & 0 & 0 \\
\hline Point Hope & 0 & 0 & 0 & 0 & 0 & 0 & 0 & 0 & 0 & 0 & 0 & 0 \\
\hline De Long Mts. & 1,809 & 1,350 & 1,386 & 0 & 0 & 0 & 0 & 107 & 0 & 1,809 & 1,457 & 1,386 \\
\hline Phillip Smith Mts. & 13 & 9 & 9 & 5 & 2 & 2 & 0 & 1 & 1 & 18 & 12 & 12 \\
\hline Noatak & 184 & 187 & 66 & 0 & 0 & 0 & 0 & 0 & 0 & 184 & 187 & 66 \\
\hline Baird Mts. & 299 & 130 & 114 & 0 & 0 & 0 & 0 & 0 & 2 & 299 & 130 & 116 \\
\hline Ambler River & 110 & 104 & 110 & 0 & 0 & 0 & 0 & 0 & 7 & 110 & 104 & 117 \\
\hline Survey Pass & 34 & 37 & 34 & 0 & 0 & 0 & 0 & 0 & 0 & 34 & 37 & 34 \\
\hline Wiseman & 1,767 & 1,393 & 1,385 & 6 & 3 & 4 & 143 & 90 & 90 & 1,916 & 1,486 & 1,479 \\
\hline Chandalar & 945 & 828 & 752 & 12 & 0 & 0 & 28 & 8 & 24 & 985 & 836 & 776 \\
\hline Christian & 1 & 2 & 1 & 0 & 0 & 0 & 0 & 0 & 0 & 1 & 2 & 1 \\
\hline Kotzebue & 16 & 0 & 0 & 16 & 0 & 0 & 0 & 0 & 0 & 16 & 0 & 0 \\
\hline Selawik & 0 & 0 & 0 & 0 & 0 & 0 & 0 & 0 & 0 & 0 & 0 & 0 \\
\hline Shungnak & 51 & 6 & 1 & 0 & 0 & 0 & 0 & 0 & 0 & 51 & 6 & 1 \\
\hline Hughes & 54 & 54 & 54 & 0 & 0 & 0 & 0 & 0 & 0 & 54 & 54 & 54 \\
\hline Bettles & 422 & 366 & 298 & 30 & 48 & 29 & 1 & 0 & 4 & 453 & 414 & 331 \\
\hline Teller & 383 & 380 & 488 & 0 & 0 & 0 & 145 & 98 & 30 & 528 & 478 & 518 \\
\hline Bendeleben & 1,138 & 1,107 & 839 & 9 & 2 & 0 & 158 & 249 & 32 & 1,305 & 1,358 & 871 \\
\hline Candle & 463 & 453 & 486 & 8 & 0 & 0 & 9 & 16 & 16 & 480 & 469 & 502 \\
\hline Melozitna & 134 & 131 & 125 & 6 & 0 & 0 & 0 & 9 & 4 & 140 & 140 & 129 \\
\hline Tanana & 1,596 & 1,296 & 1,027 & 1 & 0 & 0 & 19 & 123 & 117 & 1,616 & 1,419 & 1,144 \\
\hline Livengood & 3,290 & 3,578 & 3,335 & 0 & 0 & 0 & 428 & 328 & 116 & 3,718 & 3,906 & 3,502 \\
\hline Circle & 3,944 & 4,582 & 3,394 & 0 & 0 & 41 & 1,397 & 446 & 301 & 5,341 & 5,028 & 3,736 \\
\hline Charley River & 183 & 146 & 183 & 0 & 0 & 0 & 0 & 18 & 0 & 183 & 164 & 183 \\
\hline Nome & 293 & 687 & 697 & 5 & 0 & 0 & 344 & 103 & 33 & 637 & 790 & 730 \\
\hline Solomon & 881 & 329 & 396 & 24 & 0 & 0 & 40 & 256 & 16 & 945 & 585 & 412 \\
\hline Norton Bay & 110 & 91 & 110 & 0 & 0 & 0 & 0 & 0 & 0 & 110 & 91 & 110 \\
\hline Nulato & 3,178 & 3,175 & 3,175 & 10 & 0 & 0 & 0 & 78 & 0 & 3,188 & 3,253 & 3,175 \\
\hline Ruby & 974 & 1,057 & 846 & 0 & 0 & 0 & 304 & 52 & 1 & 1,278 & 1,109 & 847 \\
\hline Kantishna River & 275 & 244 & 243 & 0 & 1 & 9 & 0 & 0 & 0 & 275 & 245 & 252 \\
\hline Fairbanks & 2,505 & 2,209 & 2,158 & 0 & 0 & 0 & 419 & 303 & 206 & 2,924 & 2,512 & 2,364 \\
\hline Big Delta & 1,841 & 2,430 & 1,998 & 0 & 0 & 10 & 786 & 105 & 398 & 2,627 & 2,535 & 2,406 \\
\hline Eagle & 2,256 & 2,480 & 1,973 & 118 & 0 & 1 & 558 & 113 & 129 & 2,932 & 2,593 & 2,103 \\
\hline Unalakleet & 0 & 0 & 0 & 0 & 0 & 0 & 0 & 0 & 0 & 0 & 0 & 0 \\
\hline Ophir & 474 & 654 & 657 & 0 & 0 & 0 & 192 & 36 & 9 & 666 & 690 & 666 \\
\hline Medfra & 293 & 250 & 281 & 0 & 0 & 0 & 0 & 9 & 24 & 293 & 259 & 305 \\
\hline Mt. McKinley & 319 & 313 & 233 & 0 & 0 & 0 & 0 & 0 & 20 & 319 & 313 & 253 \\
\hline Healy & 3,289 & 3,301 & 4,307 & 736 & 135 & 605 & 172 & 187 & 84 & 4,197 & 3,623 & 4,996 \\
\hline Mt. Hayes & 4,682 & 3,273 & 2,871 & 56 & 41 & 240 & 247 & 188 & 15 & 4,985 & 3,502 & 3,126 \\
\hline Tanacross & 1,150 & 1,185 & 1,144 & 0 & 0 & 0 & 165 & 79 & 19 & 1,315 & 1,264 & 1,163 \\
\hline Holy Cross & 9 & 0 & 5 & 0 & 0 & 0 & 0 & 0 & 0 & 9 & 0 & 5 \\
\hline Iditarod & 620 & 1,586 & 1,399 & 646 & 54 & 0 & 437 & 63 & 10 & 1,703 & 1,703 & 1,409 \\
\hline McGrath & 325 & 348 & 329 & 0 & 0 & 0 & 238 & 0 & 0 & 563 & 348 & 329 \\
\hline Talkeetna & 1,884 & 2,197 & 1,758 & 5 & 0 & 0 & 181 & 141 & 111 & 2,070 & 2,338 & 1,869 \\
\hline Talkeetna Mts. & 1,907 & 1,528 & 770 & 16 & 0 & 3 & 122 & 177 & 120 & 2,045 & 1,705 & 893 \\
\hline Gulkana & 19 & 24 & 20 & 0 & 0 & 0 & 21 & 2 & 0 & 40 & 26 & 20 \\
\hline Nabesna & 246 & 189 & 354 & 0 & 0 & 0 & 0 & 71 & 4 & 246 & 260 & 358 \\
\hline Russian Mission & 58 & 48 & 51 & 5 & 0 & 0 & 0 & 0 & 0 & 63 & 48 & 51 \\
\hline Sleetmute & 231 & 267 & 185 & 40 & 0 & 0 & 45 & 0 & 0 & 316 & 267 & 185 \\
\hline Lime Hills & 28 & 122 & 102 & 0 & 0 & 0 & 0 & 0 & 0 & 28 & 122 & 102 \\
\hline
\end{tabular}

- Total count based on all documents recorded through January 1, 1990.

${ }^{b}$ Quadrangles numbered northwest to southeast according to DGGS-DOM numbering and Kardex systems.

'Excluding an undetermined number of claims on state selected land. 


\begin{tabular}{|c|c|c|c|c|c|c|c|c|c|c|c|c|c|}
\hline \multirow{3}{*}{\multicolumn{2}{|c|}{ Quadrangle }} & \multirow{2}{*}{\multicolumn{3}{|c|}{$\begin{array}{l}\text { Active claims } \\
\text { assessment work }\end{array}$}} & \multicolumn{6}{|c|}{ New claims staked } & \multirow{2}{*}{\multicolumn{3}{|c|}{$\begin{array}{c}\text { Total } \\
\text { active claims }\end{array}$}} \\
\hline & & & & & \multicolumn{3}{|c|}{ Federal } & \multicolumn{3}{|c|}{ State } & & & \\
\hline & & 1988 & $\underline{1989}$ & 1990 & 1988 & $\underline{1989}$ & 1990 & 1988 & $\underline{1989}$ & 1990 & $\underline{1988}$ & $\underline{1989}$ & 1990 \\
\hline 84 & Tyonek & 4,632 & 5,340 & 5,137 & 0 & 0 & 0 & 63 & 11 & 26 & 4,695 & 5,351 & 5,163 \\
\hline 85 & Anchorage & 906 & 407 & 689 & 9 & 2 & 0 & 71 & 89 & 181 & 986 & 498 & 870 \\
\hline 86 & Valdez & 305 & 414 & 465 & 102 & 145 & 10 & 8 & 20 & 7 & 321 & 579 & 482 \\
\hline 87 & McCarthy & 205 & 186 & 103 & 0 & 0 & 0 & 0 & 0 & 0 & 205 & 186 & 103 \\
\hline 91 & Bethel & 454 & 485 & 380 & 24 & 0 & 0 & 37 & 48 & 0 & 515 & 533 & 380 \\
\hline 92 & Taylor Mts. & 204 & 273 & 263 & 0 & 0 & 0 & 168 & 12 & 0 & 372 & 285 & 263 \\
\hline 93 & Lake Clark & 395 & 588 & 387 & 0 & 0 & 0 & 150 & 10 & 0 & 495 & 598 & 387 \\
\hline 94 & Kenai & 12 & 12 & 14 & 0 & 0 & 0 & 5 & 0 & 0 & 17 & 12 & 14 \\
\hline 95 & Seward & 2,340 & 2,024 & 1,484 & 379 & 131 & 38 & 30 & 20 & 36 & 2,749 & 2,175 & 1,558 \\
\hline 96 & Cordova & 15 & 0 & 0 & 0 & 1 & 0 & 0 & 0 & 0 & 15 & 1 & 0 \\
\hline 97 & Bering Glacier & 310 & 283 & 274 & 0 & 0 & 0 & 0 & 0 & 0 & 310 & 283 & 274 \\
\hline 101 & Goodnews & 2 & 39 & 75 & 0 & 0 & 0 & 39 & 0 & 0 & 41 & 39 & 75 \\
\hline 102 & Dillingham & 7 & 0 & 0 & 0 & 0 & 0 & 0 & 0 & 0 & 7 & 0 & 0 \\
\hline 103 & Iliamna & 572 & 700 & 780 & 0 & 0 & 0 & 720 & 133 & 86 & 1,292 & 833 & 866 \\
\hline 104 & Seldovia & 13 & 9 & 10 & 0 & 0 & 0 & 0 & 0 & 0 & 13 & 9 & 10 \\
\hline 105 & Blying Sound & 1 & 1 & 1 & 0 & 0 & 0 & 0 & 0 & 0 & 1 & 1 & 1 \\
\hline 107 & Icy Bay & 6 & 4 & 0 & 14 & 0 & 0 & 0 & 0 & 0 & 20 & 4 & 0 \\
\hline 108 & Yakutat & 1 & 1 & 1 & 0 & 0 & 0 & 0 & 2 & 0 & 1 & 3 & 1 \\
\hline 109 & Skagway & 511 & 485 & 473 & 0 & 2 & 27 & 0 & 19 & 0 & 511 & 506 & 500 \\
\hline 111 & Mt. Fairweather & 2 & 4 & 4 & 18 & 0 & 4 & 1 & 0 & 2 & 20 & 4 & 10 \\
\hline 112 & Juneau & 3,428 & 3,251 & 3,947 & 890 & 293 & 255 & 62 & 49 & 54 & 4,380 & 3,593 & 4,056 \\
\hline 113 & Taku River & 0 & 0 & 0 & 0 & 0 & 0 & 0 & 0 & 0 & 0 & 0 & 0 \\
\hline 114 & Sitka & 644 & 432 & 289 & 9 & 0 & 94 & 11 & 0 & 4 & 664 & 432 & 387 \\
\hline 115 & Sumdum & 147 & 143 & 121 & 14 & 19 & 97 & 0 & 0 & 0 & 161 & 162 & 218 \\
\hline 116 & Port Alexander & 184 & 184 & 107 & 0 & 1 & 0 & 0 & 0 & 0 & 184 & 185 & 107 \\
\hline 117 & Petersburg & 789 & 480 & 448 & 109 & 23 & 89 & 5 & 0 & 0 & 903 & 503 & 537 \\
\hline 118 & Bradfield Canal & 122 & 107 & 361 & 35 & 262 & 134 & 0 & 0 & 0 & 157 & 469 & 495 \\
\hline 119 & Craig & 780 & 905 & 943 & 337 & 262 & 24 & 57 & 0 & 0 & 1,174 & 1,167 & 967 \\
\hline 120 & Ketchikan & 367 & 391 & 391 & 34 & 137 & 107 & 0 & 1 & 51 & 401 & 529 & 549 \\
\hline 121 & Dixon Entrance & 184 & 181 & 186 & 74 & 0 & 65 & 0 & 0 & 0 & 258 & 181 & 251 \\
\hline 122 & Prince Rupert & 9 & 0 & 0 & 0 & 0 & 0 & 0 & 0 & 0 & 9 & 0 & 0 \\
\hline 123 & Hagemeister Island & 505 & 374 & 216 & 0 & 0 & 0 & 36 & 0 & 0 & 541 & 374 & 216 \\
\hline 126 & Mt. Katmai & 0 & 0 & 0 & 0 & 0 & 0 & 0 & 0 & 0 & 0 & 0 & 0 \\
\hline 127 & Afognak & 2 & 2 & 2 & 0 & 0 & 0 & 0 & 0 & 36 & 2 & 2 & 38 \\
\hline 130 & Karluk & 0 & 0 & 0 & 0 & 0 & 0 & 0 & 0 & 0 & 0 & 0 & 0 \\
\hline 133 & Chignik & 71 & 71 & 71 & 0 & 0 & 0 & 0 & 0 & 0 & 71 & 71 & 71 \\
\hline 135 & Trinity Islands & 895 & 437 & 380 & 0 & 0 & 0 & 1 & 49 & 83 & 896 & 486 & 463 \\
\hline 138 & Port Moller & 38 & 17 & 16 & 0 & 0 & 0 & 0 & 9 & 0 & 38 & 26 & 16 \\
\hline TC & TAL & $\overline{63,694}$ & $\overline{64,123}$ & $\overline{58,067}$ & $\overline{3,786}$ & $\overline{1,664}$ & $\overline{2,573}$ & $\overline{5, \overline{002}}$ & $\overline{8,062}$ & $\overline{1,888}$ & $\overline{75,542}$ & $\overline{67,948}$ & $\overline{62,528}$ \\
\hline
\end{tabular}




\section{APPENDIX B}

\section{Prospecting sites on state lands}

Compiled by Erik Hansen (DOM)

\begin{tabular}{|c|c|c|c|c|}
\hline & Quadrangle & New sites & Extensions & Iotal \\
\hline 30 & Wiseman & 6 & 0 & 6 \\
\hline 31 & Chandalar & 6 & 4 & 10 \\
\hline 35 & Kotzebue & 16 & 0 & 16 \\
\hline 39 & Bettles & 6 & 0 & 6 \\
\hline 43 & Teller & 15 & 0 & 15 \\
\hline 44 & Bendeleben & 10 & 47 & 57 \\
\hline 49 & Livengood & 6 & 37 & 43 \\
\hline 50 & Circle & 80 & 116 & 196 \\
\hline 52 & Nome & 7 & 0 & 7 \\
\hline 53 & Solomon & 9 & 0 & 9 \\
\hline 55 & Nulato & 1 & 0 & 1 \\
\hline 58 & Fairbanks & 28 & 9 & 37 \\
\hline 59 & Big Delta & 79 & 0 & 79 \\
\hline 60 & Eagle & 2 & 9 & 11 \\
\hline 64 & Ophir & 4 & 42 & 46 \\
\hline 65 & Medira & 7 & 0 & 7 \\
\hline 67 & Healy & 39 & 33 & 72 \\
\hline 68 & Mt. Hayes & 20 & 0 & 20 \\
\hline 69 & Tanacross & 7 & 0 & 7 \\
\hline 75 & Talkeetna & 39 & 0 & 39 \\
\hline 76 & Talkeetna Mts. & 30 & 18 & 48 \\
\hline 84 & Tyonek & 0 & 3 & 3 \\
\hline 85 & Anchorage & 18 & 0 & 18 \\
\hline 86 & Valdez & 34 & 0 & 34 \\
\hline 112 & Juneau & 35 & 7 & 42 \\
\hline 120 & Ketchikan & 6 & 0 & 6 \\
\hline 135 & Trinity Islands & 8 & 0 & 8 \\
\hline \multicolumn{2}{|c|}{ TOTAL } & $\overline{518}$ & $\overline{325}$ & $\overline{843}$ \\
\hline
\end{tabular}




\section{APPENDIX C \\ State and federal agencies, and private interest groups involved in mineral development activities, 1990 \\ (Note: The 1991 Service Directory of the Alaska Miners Association lists technical and professional consultants and companies available for work in Alaska. The report is available for $\$ 12$ from the Association's Anchorage office. See p. 57 for the address.)}

\section{STATE OF ALASKA AGENCIES}

\section{DEPARTMENT OF COMMERCE AND}

ECONOMIC DEVELOPMENT

State Office Building, 9th FI.

P.O. Box D (mailing)

Juneau, AK 99811

(907) 465-2500

Commissioner - Dr. Glenn A. Olds

Function: Promotes economic development in Alaska.

Division of Economic Development State Office Building, 9th FI.

P.O. Box D (mailing)

Juneau, AK 99811

(907) 465-2017

Director - Paul Fuhs

Deputy Director - Tom Lawson

Development Specialist - Al Clough

1001 Noble St., Ste. 360

Fairbanks, AK 99701

(907) 452-7464

Development Specialist - Richard Swainbank

Function: Primary advocacy agency in state government for economic growth. Researches and publishes economic data on Alaska's mining industry. Provides information and assistance to new or developing businesses.

\section{DEPARTMENT OF ENVIRONMENTAL CONSERVATION \\ 3220 Hospital Dr. \\ P.O. Box O (mailing) \\ Juneau, AK 99811-1800 \\ (907) 465-2600 \\ Public Information (907) 465-2606 \\ Commissioner - John A. Sandor}

Function: Issues permits for activities, including mining, that affect air or water quality or involve land disposal of wastes. Sets air- and water-quality standards. Inspects, monitors, and enforces environmental quality statutes, regulations, and permits. Reviews all federal permits.

Northem Regional Office

1001 Noble St., Ste. 350

Fairbanks, AK 99701

(907) 452-1714

Regional Supervisor - William McGee
Southcentral Regional Office

3601 C St., Ste. 1350, Frontier Bldg.

Anchorage, AK 99503

(907) 563-6529

Permit Information (907) 563-6529

(collect calls accepted)

Regional Supervisor - Bill Lamoreaux

Nome District Office

P.O. Box 1815

Nome, AK 99762

(907) 443-2600

District Manager - Randy Romenesko

Southeastern Regional Office

9000 Old Glacier Hwy.

P.O. Box 32420 (mailing)

Juneau, AK 99803

(907) 789-3151

Permit information (907) 465-2615

(collect calls accepted)

Regional Supervisor - Dick Stokes

DEPARTMENT OF FISH AND GAME

Capital Office Park

P.O. Box 3-2000 (mailing)

Juneau, AK 99802

Commissioner - Carl L. Rosier

(907) 465-4100

Habitat Division Director - Frank Rue (907) 465-4105

Function: Protects habitat in fish streams and manages refuges, sanctuaries, and critical habitats. Requires permits for any work involving: the blockage of fish passage; equipment crossings or operation in streams with anadromous fish; use, diversion, or pollution of streams containing anadromous fish; construction, exploration, or development work in state game refuges, game sanctuaries, and critical habitat areas.

Central Regional Office

Habitat Division

1300 College Rd.

Fairbanks, AK 99701

(907) 451-6192

Regional Supervisor - Alvin Ott

Southcentral Regional Office

Habitat Division

333 Raspberry Rd.

Anchorage, AK 99518-1599

(907) 267-2335

Regional Supervisor - Lance Trasky
Southeastern Regional Office

Habitat Division

803 3rd St., 1st FI.

P.O. Box 20 (mailing)

Douglas, AK 99824

(907) 465-4290

Regional Supervisor - Rick Reed

\section{OFFICE OF MANAGEMENT}

AND BUDGET

Division of Governmental Coordination

431 North Franklin St.

P.O. Box AW (mailing)

Juneau, AK 99811-0165

(907) 465-3562

Director - Paul Rusanowski

Function: Conducts coordinated state review of permits for mining projects within Alaska's Coastal Management Zone. Provides information to applicants on project design for consistency with the policies and standards of the Alaska Coastal Management Program. Coordinates state response to direct federal actions, including proposed regulations, that affect Alaska's mining industry.

Northem Regional Office

675 Seventh Ave.

Station $\mathrm{H}$ (mailing)

Fairbanks, AK $99701-4596$

(907) 451-2818

Project Coordinator - Patti Wightman

Southcentral Regional Office

3601 C St., Ste. 370, Frontier Bldg.

Anchorage, AK 99503-5930

(907) 561-6131

Project Coordinator - Patty Bielawski

Southeastern Regional Office

431 North Franklin St.

P.O. Box AW (mailing)

Juneau, AK 99811-0165

(907) 465-3562

Project Coordinator - Lorraine Marshall

DEPARTMENT OF NATURAL RESOURCES 400 Willoughby Ave., 5 th FI.

Juneau, AK 99801

(907) 465-2400

Commissioner - Harold Heinze

Function: Principal state agency that administers Alaska's state lands. 
Division of Forestry

3601 C St., Ste. 1058, Frontier Bidg.

P.O. Box 107005 (mailing)

Anchorage, AK 99510-7005

(907) 762-2501

Director-Malcolm R. Dick, Jr.

Function: Establishes guidelines to manage mining in state forests.

Northern Regional Office

3700 Airport Way

Fairbanks, AK 99709-4699

(907) 451-2660

Regional Forester - Lester Fortune

Southcentral Regional Office

3601 C St., Ste. 1008, Frontier Bldg.

P.O. Box 107005 (mailing)

Anchorage, AK 99510-7005

(907) 762-2511

Regional Forester - Dave Wallingford

Southeastern Regional Office

400 Willoughby Ave., 5 th FI.

Juneau, AK 99801

(907) 465-2491

Regional Forester - Jim McAllister

\section{Division of Geological \&}

Geophysical Surveys

794 University Ave., Ste. 200

Fairbanks, AK 99709-3645

(907) 474-7147

Acting Director - Dr. Thomas E. Smith

Function: Conducts geological and geophysical surveys to determine the potential of Alaskan land for production of metals, minerals, fuels, and geothermal resources; locations and supplies of construction materials; potential geologic hazards to buildings, roads, bridges, and other installations and structures; and other surveys and investigations as will advance knowledge of the geology of Alaska and general geologic inventories. Publishes a variety of reports that contain the results of these investigations. Advises the public and government agencies on geologic issues. Maintains a library of geologic bulletins, reports, and periodicals. Maintains a drill-core storage facility at Eagle River.

Southcentral Regional Office 400 Willoughby Ave., 3rd FI. Juneau, AK 99801

(907) 465-2633

Geologist - Roman J. Motyka

Division of Land

3601 C St., Ste. 814, Frontier Bldg.

P.O. Box 107005 (mailing)

Anchorage, AK 99510-7005

(907) 762-2692

Acting Director - Ron Swanson
Function: Manages surface estate and resources, including materials (gravel, sand, and rock). Handles statewide and regional landuse planning. Issues leases, material-sale contracts, mill-site permits, landuse permits, and easements for temporary use of state land and access roads.

Northern Regional Office

3700 Airport Way

Fairbanks, AK $99709-4699$

(907) 451-2700

Regional Manager - Rick Smith

Southcentral Regional Office

3601 C St., Ste. 1080, Frontier Bldg.

P.O. Box 107005 (mailing)

Anchorage, AK 99510-7005

(907) 762-2253

Regional Manager - Veronica Gilbert

Southeastern Regional Office

400 Willoughby Ave., Ste. 400

Juneau, AK 99801

(907) 465-3400

Regional Manager - Andrew Pekovich

Division of Mining

3601 C St., Ste. 800, Frontier Bldg.

P.O. Box 107016 (mailing)

Anchorage, AK 99510-7016

(907) 762-2165

Acting Director - Sam Dunaway

Mining Information - Bob Stuvek

Function: Principal agency for management of mining and reclamation on state land in Alaska. Maintains a mining information office in Fairbanks. Issues property rights to leasable minerals; adjudicates locatable mineral filings. Issues permits for hard-rock and placermining activity. Maintains records of mineral locations, permits, and leases. Provides technical, legal and land-status information. Administers the Alaska Surface Mining Control and Reclamation Act (ASMACRA), which includes permitting and inspection of coal mining activity and reclamation of abandoned mines.

Northern Regional Office

3700 Airport Way

Fairbanks, AK $99709-4699$

(907) 451-2790

Regional Manager - John Wood

Mining Information - Erik Hansen

Division of Parks and Outdoor Recreation 3601 C St., Ste. 1200 , Frontier Bldg.

P.O. Box 107001 (mailing)

Anchorage, AK 99510-7001

(907) 762-2602

Director - Neil Johannsen
Function: Manages approximately $3,000,000$ acres of state park lands primarily for recreational uses, preservation of scenic values, and watershed. Responsible for overseeing mining access, recreational mining activity, and valid mining claim inholdings within state park lands.

Northern Regional Office

3700 Airport Way

Fairbanks, AK 99709-4699

(907) 451-2695

Regional Manager - Mike Lee

Southcentral Regional Office

3601 C St., Ste., 1280, Frontier Bldg.

P.O. Box 107001 (mailing)

Anchorage, AK 99510-7001

(907) 762-2617

Regional Manager - Al Meiners

Southeastern Regional Office 400 Willoughby Ave., 3rd FI.

Juneau, AK 99801

(907) 465-4563

Regional Manager - William Garry

History and Archaeology Section 3601 C St., Ste. 1278, Frontier BIdg.

P.O. Box 107001 (mailing)

Anchorage, AK 99510-7001

(907) $762-2626$

Section Chief and State Historic Preservation

Officer - Judith Bittner

State Archaeologist - Robert Shaw

\section{Division of Water}

3601 C St., Ste. 800, Frontier Bldg.

P.O. Box 107005 (mailing)

Anchorage, AK 99510-7005

(907) 762-2145

Director - Ric Davidge

Function: Manages water resources of the state; issues water-appropriation permits and certificates; responsible for safety of all dams in Alaska; conducts surveys to determine the locations, quantity, and quality of ground and surface water.

Northern Regional Office

3700 Airport Way

Fairbanks, AK 99709-4699

(907) 451-2772

Hydrologist - Scolt Ray

Water Quality Lab - 474-7713

Eagle River Office

18225 Fish Hatchery Road

P.O. Box 772116 (mailing)

Eagle River, AK 99577-2116

(907) 696-0070

Section Chief - William E. Long 
Southeastern Regional Office 400 Willoughby Ave., 3 rd FI. Juneau, AK 99801

(907) 465-2533

Hydrologist - Rick Noll

\section{DEPARTMENT OF PUBLIC SAFETY}

450 Whittier $\mathrm{St}$.

P.O. Box N (mailing)

Juneau, AK 99811

(907) 465-4322

Commissioner - Richard Burton

Division of Fish and Wildlife Protection 5700 East Tudor Rd.

Anchorage, AK 99507

(907) 269-5509

Director - Colonel Jack W. Jordan

Function: Enforce state laws, in particular AS Title 16. Acts as enforcement arm for Alaska Department of Fish and Game.

\section{DEPARTMENT OF REVENUE}

State Office Bldg.

11 th $\mathrm{Fl}$., Entrance A

P.O. Box $\mathrm{S}$ (mailing)

Juneau, AK 99811-0400

(907) 465-2300

Commissioner - Lee E. Fisher

Income and Excise Tax Audit Division

State Office Bldg.

P.O. Box SA (mailing)

Juneau, AK $99811-0400$

(907) 465-2343

Audit Office Supervisor - Paul Dick

Function: Issues licenses (including mining) for production and sale of minerals.

Division of Audit

550 W. 7th Ave.

Anchorage, AK 99501

(907) 276-5364

Director - Larry E. Meyers

Function: Administers mining-license tax which is based on net income, including royalties. On application, will grant certificate of tax exemption for first year of new mining operations, except for mining of sand and gravel. Tax returns must be filed annually.

\section{UNIVERSITY OF ALASKA}

Fairbanks, AK 99775-0760

College of Natural Sciences

Department of Geology \& Geophysics

Duckering Bldg., $\mathrm{Rm} 437$

(907) 474-7565

Department Head - Samuel E. Swanson
Function: Provides undergraduate and graduate education in geology and geophysics and conducts basic and applied research in geologic sciences. Offers B.S., M.S., and Ph.D. program options in general geology, economic geology, petroleum geology, geophysics, and ice-snow-permafrost geophysics.

\section{School of Mineral Engineering}

Brooks Bidg., Rm. 209

(907) 474-7366

Acting Dean - Russell Ostermann

Function: Provides undergraduate and graduate education programs in geological engineering, mining engineering, mineral preparation engineering, and petroleum engineering. Offers mining extension programs in both urban and rural areas. Through research programs conducts laboratory and field studies to promote mineral and energy development.

Mineral Industry Research Laboratory (MIRL) O'Neill Resources Bldg., Rm. 212

(907) 474-7135 or 7136

Acting Director - Russell Ostermann

Associate Director - P.D. Rao

Function: Conducts applied and basic research in exploration, development, and utilization of Alaska's mineral and coal resources with emphasis on coal characterization, coal preparation, mineral beneficiation, fine gold recovery, hydrometallurgy, and environmental concerns. Publishes reports on research results and provides general information and assistance to the mineral industry.

\section{Mining Extension Program}

Duckering Bldg., Rm. 469

(907) 474-7702

Director - James A. Madonna

Function: Offers prospecting and introductory mineral and mining courses under an open admissions policy.

Mining and Petroleum Training Service University of Alaska Anchorage

155 Smithway, Ste. 104

Soldotna, AK 99669

Director - Dennis D. Steffy

Asst. Director - Debbie J. Kendrick (907) 262-2786

Function: Provides direct training and assistance to mine operators, service and support companies and governmental agencies in mine safety and health, mining extension, vocational mine training and technical transfer. Specialized training services in hazardous materals, first aid and CPR, industrial hygiene and professional safety education and consulting are available on demand.
FEDERAL AGENCIES

U.S. DEPARTMENT OF THE INTERIOR

Office of the Secretary

1689 C St., Ste. 100

Anchorage, AK 99501

(907) 271-5485

Special Assistant to the Secretary -

Curtis V. McVee

Staff Coordinator - Ronald B. McCoy

Function: Coordinates the Department of the Interior's policy and stewardship with DOI bureaus for the management of over 200 million acres of public land in

Alaska. The Special Assistant to the Secretary also serves as the Chairman of the Federal Subsitence Management Board.

Bureau of Land Management

Alaska State Office

22 West 7th Ave., \#13

P.O. Box 13 (mailing)

Anchorage, AK 99513-7599

State Director-Edward F. Spang

Mineral Resources Deputy State Director John Santora

(907) 271-3343

Mineral Development Program Leader Earl Boone

(907) $271-4212$

Surface Management Program Oversight Ruth Stockie

(907) 271-4434

Public Room - (907) 271-5960

Function: Administers federal public lands (except national parks, wildlife refuges, national monuments, national forests, and military withdrawa/s). Issues leases for all federal leasable minerals including oil and gas, coal, phosphates, and oil shale. Arranges for sale of minerals other than leasable or salable materials, including sand, gravel, or stone. Issues right-of-way and special-use permits. Monitors mining operations to insure protection of surface resources. Maintains land-status plats and issues patents. Records federal mining claims and annual assessment affidavits.

Anchorage District Office

6881 Abbott Loop

Anchorage, AK 99507

(907) 267-1200

District Manager - Dick Vernimen

Arctic District Office

1150 University Ave.

Fairbanks, AK 99709-3844

(907) 474-2302

District Manager - Dee Ritchie

Nome Field Office

P.O. Box 952 (mailing)

Nome, AK 99762

(907) 443-2177

Natural Resource Specialist - Norm Messenger 
Glennallen District Office

P.O. Box 147 (mailing)

Glennallen, AK 99588

(907) 822-3217

District Manager - Gene Keith

Kobuk District Office

1150 University Ave.

Fairbanks, AK 99709-3844

(907) 474-2332

District Manager - Helen Hankins

Steese-White Mountain Office

1150 University Ave.

Fairbanks, AK 99709-3844

(907) 474-2351

District Manager - Roger Bolstad

Kotzebue Field Office

P.O. Box 262 (mailing)

Kotzebue, AK 99752

(907) 442-3430

Natural Resource Specialist - Vacant

Tok Field Office

P.O. Box 309 (mailing)

Tok, AK 99780

(907) 883-5121

Manager - Bob Burritt

Fairbanks Support Center and Land Information Office (Public Room)

1150 University Ave.

Fairbanks, AK 99709-3844

(907) 474-2250

Support Center Manager - James Murray

Function: Primary contact for information on Interior and northern regions.

\section{U.S. Bureau of Mines}

Alaska Fieid Operations Center

201 East 9th Ave., Ste. 101

Anchorage, AK 99501

(907) 271-2455

Chief - Donald P. Blasko

Branch Chief - Vacant

Function: Alaska programs are designed to help develop a viable mineral industry in Alaska with an emphasis on strategic minerals. The two main thrusts of the programs are to provide data on mineral reserves needed by government agencies at all levels, but particularly by Congress and land managers, and to generate, accumulate, and supply mineral data to the mining industry. All Alaska projects are parts of mutually supportive programs: mineral land assessment, minerals availability, minerals policy analysis, state activities, and technology transfer.
Alaska Technology Transfer Office

201 East 9th Ave., Ste. 101

Anchorage, AK 99501

(907) 271-2455

Juneau Branch Office

P.O. Box 20550 (mailing)

Juneau, AK $99802-0550$

(907) 364-2111

Branch Chief - David Cames

Fairbanks Field Office

794 University Ave.

Fairbanks, AK 99709

(907) 479-4277

Section Supervisor - Vacant

U.S. Fish and Wildlife Service

Region 7 Office

1011 East Tudor Rd.

Anchorage, AK 99503

(907) 786-3522

Regional Director - Walter O. Stieglitz

Assistant Regional Director (Fish and Wildlife Enhancement) - Rowan W. Gould

Function: Administers the federal public lands in national wildife refuges, issues special-use permits for activities on refuges, reviews permits and applications for various mining activities on all private and public lands and waters, and provides information to regulatory agencies on fish and wildlife and their habitat. Makes recommendations to regulatory agencies to mitigate adverse environmental impacts.

Fairbanks Fish and Wildlife Enhancement Ecological Service/Endangered Species Branch

101 12th Ave., Rm. 232

Box No. 20 (mailing)

Fairbanks, AK 99701

(907) 456-0203

Acting Field Supervisor - Patrick Sousa

Juneau Fish and Wildlife Enhancement

Federal Bldg., Rm. 417

P.O. Box 21287 (mailing)

Juneau, AK 99802

(907) 586-7240

Field Supenvisor - Nevin Holmberg

Anchorage Fish and Wildlife Enhancement

605 West 4th Ave., Rm. 62

Anchorage, AK 99501

(907) 271-2888

Fiełd Supervisor - Dave McGillivary

U.S. Geological Survey

4230 University Dr.

Anchorage, AK 99508-4663

(907) 561-1181

Chief, Branch of Alaskan Geology Willis $\mathrm{H}$. White
Function: Investigates and reports on physical resources; configuration and character of land surface; composition and structure of underlying rocks; and quality, volume, and distribution of water and minerals. Conducts 1:250,000-scale geologic mapping under the auspices of the Alaska Mineral Resource Assessment Program (AMRAP).

Alaska Distribution USGS Section (for maps and brochures)

Federal Bldg.

10112 th Ave.

Fairbanks, AK 99701

(907) 456-0244

U.S. Geological Survey Earth Science Information Center

Geologic Division

4230 University Dr., Rm. 101

Anchorage, AK $99508-4667$

(907) $561-1181$

National Park Service

Alaska Regional Office

2525 Gambell St.

Anchorage, AK 99503

(907) 257-2643

Regional Director - Boyd Evison

Chief, Minerals Management - Floyd Sharrock

(907) 257-2626

Mining Engineer - Lynn S. Griffiths

(907) 257-2629

Function: Administers lands within the national park system in Alaska. Manages valid prior-right mining claims in parklands through plans of operation under Mining in Parks Act, National Park Service regulations, and other applicable federal and state laws and regulations.

\section{U.S. DEPARTMENT OF LABOR}

Mine Safety and Health Administration

117 107th Ave. NE., Rm. 100

Bellevue, WA 98004

(206) 442-7037

Bellevue Field Office Supervisor Walter Turner (administers portions of Alaska south of Yukon River)

Juneau Field Office

Federal Building

107 West 9 th

P.O. Box 22049 (mailing)

Juneau, AK 99802

(907) 586-7165

Inspector - Bob Casey

Mine Safety and Health Administration

205 North 4th St., Rm. 103

Coeur d'Alene, ID 83814

(208) $667-6680$

Coeur d'Alene Field Office Supervisor Bill Wilson (administers portions of Alaska north of Yukon River) 
Function: Administers health and safety standarcs to protect the health and safety of metal, nonmetal and coal miners. Cooperates with the State to develop health and safety programs and develops training programs to help prevent mine accidents and occupationally caused diseases. Under agreement with the Coal Mine Safety and Health Office, the MSHA metal/nonmetal section has assumed responsibility for enforcement and training activities at coal mines in Alaska.

Mine Safety and Health Administration Coal Mine Safety and Health, District 9 P.O. Box 25367, DFC

Denver, CO 80225

(303) 231-5458

District Manager - William A. Holgate

Function: Administers health and safety standards according to the Code of Federal Regulations to protect the health and safety of coal miners; requires that each operator of a coal mine comply with these standards. Cooperates with the State to develop health and safety programs and develops training programs to help prevent coal or other mine accidents and occupationally caused diseases in the industry.

\section{U.S. DEPARTMENT OF AGRICULTURE}

\author{
U.S. Forest Service \\ Regional Office \\ Federal Bidg. \\ P.O. Box 21628 (mailing) \\ Juneau, AK 99802-1628 \\ (907) 586-7847 \\ Regional Forester - Michael A. Barton
}

Function: Helps meet national mineral and energy needs by encouraging and supporting environmentally sound mineral enterprises on national forest system lands. Provides joint administration of general mining laws on national forest system lands with the Bureau of Land Management. Cooperates with Department of Interior agencies in the review and issuance of mineral leases. Issues permits for disposal of sand, gravel, and stone.

\section{U.S. ENVIRONMENTAL PROTECTION AGENCY}

\section{Region 10 Headquarters}

1200 6th Ave.

Seattle, WA 98101

(206) $553-1200$

Acting Regional Administrator Ms. Dana Rasmussen
Function: Issues National Pollutant Discharge Elimination Systern (NPDES) permits under the Clean Water Act to regulate effluent discharges. Maintains regulatory and review authority over wetland and NEPA/EIS-related issues.

Alaska Operations Office

222 West 7th Ave., \#19

Box 19 (mailing)

Anchorage, AK 99513

(907) 271-5083

Assistant Regional Administrator Alvin L. Ewing

Alaska Operations Office

3200 Hospital Dr., Ste. 101

Juneau, AK 99801

(907) 586-7619

Chief, State Operations Section - Steven Torok

\section{U.S. DEPARTMENT OF THE ARMY}

Corps of Engineers

Regulatory Branch

P.O. Box 898

Anchorage, AK 99506-0898

District Engineer - Col. William W. Kakel

Write: Attention: NPACO-R-S, or

Call: Chief of Compliance Section

(907) 753-2712 or (800) 478-2712

(in Alaska only)

Function: Regulates work in navigable waters of United States and discharge of dredged or fill material into United States waters, including wetlands. Examples of regulated mining activities include construction of berms, dikes, diversion pads, stockpiles, and reclamation activities.

\section{COOPERATIVE STATE-FEDERAL AGENCIES}

Alaska Public Lands Information Center

250 Cushman St., Ste. 1A

Fairbanks, AK 99701

(907) 451.7352

Manager - Karla Zervos

Assistant Manager - Lenore Heppler

Function: Clearinghouse for general information about land and resources in Alaska. Information sources include U.S. Forest Service, U.S. Fish and Wildlife Service, U.S. Bureau of Land Management, U.S. Geological Survey, Alaska Departments of Natural Resources and Fish and Game, and Alaska Division of Tourism.

\section{BOARDS AND COMMISSIONS}

\section{Alaska Minerals Commission}

P.O. Box 80148

Fairbanks, AK 99708

(907) 479-6240

Chairman - Earl H. Beistline
Function: The Mineral Commission was created by the Alaska State Legislature in 1986 to make recommendations to the Covernor and the Legislature on ways to mitigate constraints on the development of minerals in Alaska. The Commission has published reports in January 1987, January 1988, January 1989.

Citizens' Advisory Commission on Federal Areas

250 Cushman St., Ste. $4 \mathrm{H}$

Fairbanks, AK 99701

(907) 456-2012

Chairperson - Lou Williams

Executive Director - Stan Leaphart

Administrative Assistant - Michael Welsh

Function: The Citizens' Advisory

Commission on Federal Areas was established in 1981 by the Alaska Legislature to protect the rights of Alaskans to continue their traditional uses of federal lands throughout the state. This was done in response to Congressional enactment in December 1980 of the Alaska National Interest Lands Conservation Act (ANILCA), which placed millions of acres of federally owned lands into conservation system units with restrictive land-use and management requirements.

\section{Alaska Water Resources Board}

P.O. Box 107005

Anchorage, AK 99510

Chairperson - Peg Tileston

(907) 563-4375

Water Resource Board Coordinator Mary Lou Harle

(907) $762-2680$

Function: The Alaska Water Resources Board serves as an advisory group to the Governor on all matters relating to use and appropriation of water in the state of Alaska. The board has been particularly supportive of water resources legislation, including amendments to the Alaska Water Use Act for reservations of water and instream uses, basin-wide water rights adjudications, and housekeeping amendments to improve water-rights adjudication. The board has taken a keen interest in the state's water quality programs and water quality standards.

Alaska Science \& Technology Foundation 550 West 7 th Ave., Ste. 360

Anchorage, AK 99501-3555

(907) 272-4333

Executive Director - John W. Sibert

Function: The Foundation was created to make public funds available for long-term investment in economic development and technological innovation within the state and to improve the health status of its residents. Through the awarding of grants for basic and applied research, the 
Foundation will enhanc the State's economy and help build its science and engineering capabilities.

\section{CHAMBERS OF COMMERCE}

\section{Alaska State Chamber of Commerce}

415 E St., Ste. 201

Anchorage, AK 99510

(907) 278-2722

Chairman - Dr. John Sims

President - George Krusz

Regional Manager - Kathleen Tarr

Function: The State Chamber of Commerce researches and formulates positions on Alaskan resource development. Recommendations for consideration are submitted to the State Chamber of Commerce board of directors.

Juneau Chamber of Commerce

217 - 2nd St., Ste. 201

Juneau, AK 99801

(907) $586-6420$

Greater Fairbanks Chamber of Commerce 709 2nd Ave.

Fairbanks, AK 99701

(907) 452-1105

Anchorage Chamber of Commerce

437 E St., Ste. 300

Anchorage, AK 99501

(907) 272-2401

\section{NONGOVERNMENTAL GROUPS AND} ASSOCIATIONS

Alaska Miners Association, Inc.

Statewide Office

501 West Northern Lights Blvd., Ste. 203

Anchorage, AK 99503

(907) 276-0347

Statewide President - Neil MacKinnon

Executive Director - Steven C. Borell

Anchorage Branch

Chairman - Kevin Adler

501 West Northern Lights Blvd.,

Ste. 203

Anchorage, AK 99503

(907) 274-6473

Fairbanks Branch

Chairman - Josh Moore

P.O. Box 73069

Fairbanks, AK 99707

(907) $451-6650$

Juneau Branch

Chairman - David Stone

P.O. Box 21684

Juneau, AK 99802

(907) 586-2255
Kenai Branch

Chairman - Dennis Steffy

clo Mining \& Petroleum Training

Service (MAPTS)

155 Smithway, Ste. 104

Soldotna, AK 99669

(907) 262-2788

Nome Branch

Chairman - Irene Anderson

P.O. Box 1974

Nome, AK 99762

(907) 443-5296

\section{Alaska Women in Mining \\ Fairbanks Branch \\ Sandra Stillion, President \\ P.O. Box 83542 \\ Fairbanks, AK 99708 \\ (907) 455-6208}

Anchorage Branch

Ronna Bissonette, President

P.O. Box 240334

Anchorage, AK 99524

(907) 276-6762

Society of Mining Engineers

P.O. Box 625002

Littleton, $\mathrm{CO} 80162-5002$

(303) 973-9550

Alaska Section

Chairman - Richard Swainbank

1001 Noble St., Ste. 360

Fairbanks, AK 99701

(907) 452-7464

Southern Alaska Section

Chairman-Russell M. Kucinski

U.S. Nat'I. Park Service

11901 Rainbow Ave.

Anchorage, AK 99516

(907) 257.2634

Secretary Treasurer - John Rishel

WGM, Inc.

P.O. Box 100059

Anchorage, AK 99510

(907) 276-5004

American Institute of Professional Geologists 7828 Vance Dr., Ste. 103

Arvada, $\mathrm{CO} 80003$

(303) $431-0831$

Erik Opstad, President

Alaska Section

P.O. Box 9-2082

Anchorage, AK 99509

(907) 562-3279

Miners Advocacy Council

John Korobko, President

P.O. Box 73824

Fairbanks, AK 99707

(907) $479-0471$
Northwest Mining Association

David Holmes, President

414 Peyton Bldg.

Spokane, WA 99201

(509) 624-1158

Placer Miners of Alaska

Dennis Higgins, President

P.O. Box 83151

Fairbanks, AK 99708

(907) 455-6059

Resource Development Council for Alaska, Inc.

Bill Schneider, President

Becky L. Gay, Executive Director

121 N. Fireweed, Ste. 250

Anchorage, AK 99503

(907) 276-0700

Western Mining Council

Kenai Peninsula Chapter

Oscar H. Bailey, President

Old Nash Rd.

Seward, AK 99664

(907) 224-5963

\section{ORGANIZED MINING DISTRICTS}

Circle Mining and Recording District

Susan Knapman, President

P.O. Box 1273

Fairbanks, AK 99707

Fairbanks Mining District

Don Stein, President

105 Dunbar

Fairbanks, AK 99701

Forty-Mile Miners Association

Mike Busby, President

P.O. Box 71

Chicken, AK 99732

Juneau Mining District

Dr. Roger Eichman, President

P.O. Box 20765

Juneau, AK 99802

Kantishna Mining District

Sam Koppenburg, President

SRD Box 9070

Palmer, AK 99645

Iditarod Mining District

John Miscovich, President

1093 North Greengrove St.

Orange, CA 92667

Livengood-Tolovana Mining District

Rose Rybachek, President

P.O. Box 55698

North Pole, AK 99707

Seward Mining District

Tom Williams, President

Box 66

Hope, AK 99605 
Valdez Mining District

Claude Morris, President

P.O. Box 547

Girdwood, AK $99587-0547$

Yentna Mining District

John Jacobsen, President

700 Ash PI.

Anchorage, AK 99501

\section{MINERAL EDUCATION PROGRAM}

\section{ALASKA MINERALS AND ENERGY}

RESOURCE EDUCATION FUND (AMEREF)

P.O. Box 190927

Anchorage, AK 99519-0927

(907) 274-2211

Function: A nonprofit corporation formed to help prepare students in grades four through eight to make informed decisions about Alaska's mineral and energy resources.

Alaska Department of Education

P.O. Box F

Juneau, AK $99811-0500$

(907) 465-2841

Commissioner - Jerry Covey

Educational Specialist - Terri Campbell, State

Coordinator of AMEREF

\section{ENVIRONMENTAL ORGANIZATIONS}

The following two organizations submitted addresses to be included in this appendix. They have been actively involved in mining issues statewide including water quality, reclamation rent, and royalty reform.

Litigation has been sometimes used and resulted in court rulings. Both organizations state their primary interests and perspective as maintenance of environmental quality and adherence to environmental laws and regulations.

Trustees for Alaska

725 Christensen Dr., Ste. 4

Anchorage, AK 99501

Randall M. Weiner, Executive Director

Alaska Environmental Assembly

419 - 6th St., Ste. 328

Juneau, AK 99801

Executive Director - Karla Hart 


\section{APPENDIX D \\ Selected significant mineral deposits in Alaska ${ }^{\star}$ (locations shown in figs. 44-46)}

no.

1 Lik-Su - Major strata-bound massive sulfide ( $\mathrm{Zn}-\mathrm{Pb}-\mathrm{AB}_{\mathrm{B}} \mathrm{Cd}-\mathrm{Ba}$ ) deposits in black shale and cert. Proven reserve (Lik) estimate of 24 million tons of 9 percent $\mathrm{Zn}, 3.1$ percent $\mathrm{Pb}$, and $1.4 \mathrm{oz} /$ ton $\mathrm{Ag}$.

2 Red Dog - At least two major strata-bound massive sulfide deposits hosted in Pennsylvanian or Mississippian shale; similar to locality 1. Main deposit at Red Dog contains at least 85 million tons of 17.1 percent $\mathrm{Zn}, 5$ percent $\mathrm{Pb}, 2.4 \mathrm{oz} / \mathrm{ton} \mathrm{A}_{8}$; nearby Hilltop deposit contains significant undisclosed reserves.

3 Drenchwater - Mississippian and Lisburne Group shales and cherts contain three strata-bound base metal occurrences spatially related to acid volcanics. In the lowest unit a siliceous mudstone contains a 2 -ft layer with up to 23 percent zinc. An overlying gray chert contains up to 11 percent zinc and up to 5 percent lead with some silver in fracture fillings. At the top of the overlying tuffaceous layer silver-bearing zinc and lead mineralization outcrops discontinuously for at least 6,500 ft, and contains up to 26 percent zinc and 51 percent lead in a grab sample.

4 Ginny Creek - Epigenetic, disseminated $\mathrm{Zn}-\mathrm{Pb}-\mathrm{Ag}$ deposits with barite in sandstone and shale of Noatak Sandstone of Late Devonian through Early Mississippian age. Random grab samples of surface float contain 0.3 to 3.0 percent $Z n$ and highly variable amounts of $\mathrm{Pb}$ and $\mathrm{Ag}$.

5 Story Creek - Epigenetic replacement deposits of $\mathrm{Zn}-\mathrm{Pb}-\mathrm{Ag}-\mathrm{Cu}-\mathrm{Au}$ hosted in brecciated zones in Devonian Kanayut Conglomerate or Lower Mississippian Kayak Shale. Grab samples of high-grade material contain up to 0.43 percent $\mathrm{Cu}, 34$ percent $\mathrm{Pb}, 28.8$ percent $\mathrm{Zn}, 0.04 \mathrm{oz} / \mathrm{ton} \mathrm{Au}$, and $30 \mathrm{oz} / \mathrm{ton} \mathrm{Ag}$.

5a Kivliktort Mountain - Mineralized float is widespread on the north flanks of the mountain, apparently spatially related to the contact between shales at the base of the hills and coarse-grained siliceous clastic rocks on the upper slopes. Rock samples containing up to 30 percent zinc have been reported.

6 Whoopee Creek - Epigenetic replacement deposits of $\mathrm{Zn}-\mathrm{Pb}-\mathrm{Cu}$ $\mathrm{Ag}$-Au-Cd in breccia zones in Devonian Kanayut Conglomerate or Lower Mississippian Kayak Shale. Random grab samples of mineralized material contain 0.24 percent $\mathrm{Cu}, 0.37$ percent $\mathrm{Cd}$, 46 percent $\mathrm{Zn}, 44$ percent $\mathrm{Pb}, 0.14 \mathrm{oz} /$ ton $\mathrm{Au}$, and $14.8 \mathrm{oz} / \mathrm{ton} \mathrm{Ag}$.

7 Omar - Epigenetic replacement deposits of Paleozoic age; include bedded barite occurrences. Grab samples contain 15.3 percent $\mathrm{Cu}, 0.15$ percent $\mathrm{Pb}, 0.95$ percent $\mathrm{Zn}, 0.05$ percent $\mathrm{Co}$, and $0.3 \mathrm{oz}$ ton $\mathrm{Ag}$.

7a Frost - Possible 9 million tons barite in pods, lenses and waveybanded quartz-catcite-barite veins. Chalcopyrite and galena occur in the veins which cross cut Paleozoic limestone and dolomite for a minimum distance of 1 mile. Samples contain up to 13.2 percent Zn
8 Bornite - Major strata-bound Cu-Zn deposit in brecciated carbonate rock of Devonian age; $\mathbf{4 . 5 6}$ million ton orebody contains 4.0 percent $\mathrm{Cu}$ and accessory $\mathrm{Zn}$ and $\mathrm{Co}$. Larger reserve estimate of 36.2 million tons of about 2 percent $\mathrm{Cu}$ and undisclosed amount of $\mathrm{Zn}$ and $\mathrm{Co}$. At grade of 1.2 percent $\mathrm{Cu}$, reserves are 100 million tons.

9 Arctic - Major volcanogenic (Cu-Zn) massive sulfide deposit hosted in sequence of metarhyolite, metatuff, and graphitic schist of Devonian age; indicated reserves of 35 to $\mathbf{4 0}$ million tons grade 4.0 percent $C u, 5.5$ percent $\mathrm{Zn}, 0.8$ percent $\mathrm{Pb}, 1.6 \mathrm{oz} /$ ton $\mathrm{Ag}$, and $0.02 \mathrm{oz} /$ ton $\mathrm{Au}$.

10 Sun - Major ( $\mathrm{Cu}-\mathrm{Pb}-\mathrm{Zn}-\mathrm{Ag}$ ) massive sulfide deposit in sequence of middle Paleozoic metarhyolite and metabasalt; indicated 1976 gross-metal value of $\mathrm{Cu}, \mathrm{Pb}, \mathrm{Zn}$, and $\mathrm{Ag}$ was over $\$ 1$ billion. Average grades are $1-4$ percent $\mathrm{Pb}, 6-12$ percent $\mathrm{Zn}, 0.5-7$ percent $\mathrm{Cu}, 3-11 \mathrm{oz} / \mathrm{ton} \mathrm{Ag}$.

11 Smucker - Middle Paleozoic volcanogenic massive sulfide deposit; $3,000 \mathrm{ft}$ long and up to $190 \mathrm{ft}$ wide contains significant tonnage of $\mathrm{Cu}-\mathrm{Pb}-\mathrm{Zn}$ ore that grades 1.5 percent $\mathrm{Pb}, 5$ to 10 percent $\mathrm{Zn}, 3$ to $10 \mathrm{oz} /$ ton $\mathrm{Ag}$, with minor $\mathrm{Au}$.

12 Avan Hills - Disseminated chromite in layered ultramafic rocks; grab samples contain up to 4.3 percent $C r$ with $0.015 \mathrm{oz} /$ ton PGM.

13 Misheguk Mountain - Chromite occurrences similar to those in Avan Hills.

14 Klery Creek - Lode and placer Au deposits worked intermittently from 1909 through 1930s. Total production through 1931, mostly from placer deposits, estimated at $31,320 \mathrm{oz}$.

15 Ernie Lake - (Ann Creek) Strata-bound massive sulfide occurrence in metarhyolite, metatuff, and marble. Gossan zones strongly anomalous in $\mathrm{Cu}-\mathrm{Pb}-\mathrm{Zn}$ and $\mathrm{Ag}$.

16 Koyukuk-Nolan mining district - Major placer Au district; from 1893 to present, produced more than 300,000 oz Au. Significant deep placer reserves remain.

17 Chandalar mining district - Major Au producing district; substantial production in excess of 30,000 oz Au from lode and placer sources; lode gold found in crosscutting quartz veins that intrude schist and greenstone. Active development of placer deposits and lodes in progress. Estimated 45,000 tons at $2-4 \mathrm{oz} /$ ton in partially explored veins.

"This generalized summary does not describe all the known 6,400 mineral occurrences and deposits known in Alaska. In cooperation with DGGS, the U.S. Geological Survey released Bulletin 1786: "Significant metalliferous lode deposits and placer districts in Alaska," which describes 262 significant metalliferous lodes and 43 placer districts. 
18 Porcupine Lake - Stratiform fluorite occurrences and argentiferous enargite, tetrahedrite associated with felsic volcanic rocks of late Paleozoic age. Reported grades of up to 25 to 30 percent fluorite reported, with grab samples of 4.8 percent $\mathrm{Cu}$ and 0.2 percent silver.

19 Wind River - Strata-bound $\mathrm{Pb}-\mathrm{Zn}$ massive sulfide prospects; reported grades of up to 5 percent $\mathrm{Pb}$.

20 Esotuk Glacier - Disseminated Mo-Sn-W-Pb-Zn mineralization in skarns associated with Devonian(?) schistose quartz monzonite. Grab samples contain up to 0.08 percent $S n$ and 0.15 percent $W$.

21 Bear Mountain - Major stockwork Mo-W-Sn occurrence in intrusive breccia. Rock samples containing up to 0.8 percent molybdenum and 0.6 percent $W$ occur within a 35 acre area where soil samples average more than 0.2 percent $\mathrm{MOS}_{2}$, and an adjacent 25 acre area where rubble contains wolframite has soils averaging greater than 0.12 percent $\mathrm{WO}_{3}$. Rubble crop in this area indicates a Tertiary porphyry system as the source of the molybdenum and tungsten.

21a Galena Creek - steeply dipping veins contain up to 21 percent $\mathrm{Cu}$, 3.5 percent $\mathrm{Zn}$, and 1.3 percent $\mathrm{Pb}$ with $5-1 / 2 \mathrm{oz} /$ ton $\mathrm{Ag}$ on the east side of the creek, and a large area of disseminated mineralization and veinlets contains predominantly zinc on the ridge west of the creek.

22 Cape Creek - Major placer Sn producer. More than 500 tons Sn produced from 1935 to 1941; at least 500 tons produced in last 10 yr. Derived from Cape Mountain in contact zone of Cretaceous granite.

23 Buck Creek - Major placer Sn producer. More than 1,100 tons Sn produced from 1902 to 1953.

24 Lost River - Major Sn, fluorite, W, and Be deposit associated with Cretaceous Sn granite system. More than 350 tons Sn produced from skarn and greisen lode sources. Measured reserves amount to 24.6 million tons that grade 0.15 percent $\mathrm{Sn}, 16.3$ percent $\mathrm{CaF}_{2}$, and 0.03 percent $\mathrm{WO}_{3}$, based on $45,000 \mathrm{ft}$ of diamond drilling.

25 Ear Mountain - Placer $\mathrm{Sn}$ district and $\mathrm{Sn}-\mathrm{Cu}-\mathrm{Au}-\mathrm{Ag}-\mathrm{Pb}-\mathrm{Zn}$ skarn mineralization of Cretaceous age. Area also anomalous in uranium.

26 Kougarok Mountain - Sn deposit hosted in quartz-tourmalinetopaz greisen of Cretaceous age. Grades may average 0.5 percent $\mathrm{Sn}$ and 0.01 percent $\mathrm{Ta}$ and $\mathrm{Nb}$, but a high grade resource of 150,000 tons grading 1 percent + has been identified.

27 Hannum - Stratiform, carbonate hosted $\mathrm{Pb}-\mathrm{Zn}$-Ag massive sulfide deposit of middle Paleozoic age in heavily oxidized zone that ranges from 30 to $150 \mathrm{ft}$ thick. Mineralized zone reported to assay up to 10 percent $\mathrm{Pb}, 2.2$ percent $\mathrm{Zn}, 0.04 \mathrm{oz} /$ ton $\mathrm{Au}$, and $1.76 \mathrm{oz} / \mathrm{ton} \mathrm{Ag}$.

28 Independence Creek - Pb-Zn-Ag massive sulfide deposit; highgrade ore shipped in 1921 contained 30 percent $\mathrm{Pb}, 5$ percent $\mathrm{Zn}$, and $150 \mathrm{oz} /$ ton Ag. Mineralization restricted to shear zone in carbonates

29 Sinuk River - Stratiform $\mathrm{Pb}-\mathrm{Zn}-\mathrm{Ag}-\mathrm{Ba}-\mathrm{F}$ massive sulfide deposits and layered iron deposits of Paleozoic age. Mineralized zones extend over $8,000 \mathrm{ft}$ along strike.
30 Nome mining district - Major placer $\mathrm{Au}$ and lode $\mathrm{Au}$ producer. Production in excess of 4,348,000 oz Au. Sporadic Sb and W production in past.

31 Rock Creek - About 6.6 million tons grading $0.072 \mathrm{oz} /$ ton Au in vein swarms and strangers in an area $1,500 \mathrm{ft}$ long, $500 \mathrm{ft}$ maximum width and $300 \mathrm{ft}$ deep.

32 Big Hurrah - Epigenetic vein deposit in black slate and metasediments of York Slate. Deposit contains some W mineralization and has produced over $20,000 \mathrm{oz}$ Au from nearly 50,000 tons milled ore. Proven, inferred, and indicated reserves total 104,000 tons that grade $0.61 \mathrm{oz} /$ ton $\mathrm{Au}, 0.55 \mathrm{oz} /$ ton $\mathrm{Ag}$, and credits of $\mathrm{WO}_{3}$.

33 Solomon mining district - Major placer Au district; produced over 250,000 oz Au.

34 Kachauik - Uranium prospect in Cretaceous alkalic intrusive rocks. Highly anomalous geochemical values and $U$ concentrations of $1,000 \mathrm{ppm}$ reported.

35 Omalik - Vein-type Pb-Zn-Ag massive sulfide prospect in Paleozoic carbonate rocks; from 1881 to 1900 , produced 300 to 400 tons of $\mathrm{Pb}-\mathrm{Zn}$ ore that averaged about 10 percent $\mathrm{Pb}$ and $40 \mathrm{oz} /$ ton Ag. Grades of oxidized $\mathrm{Zn}$ ore reported to be up to 34 percent $\mathrm{Zn}$.

36 Windy Creek - Disseminated Mo-Pb-Zn mineralization in quart veins and skarns with reported values as high as 0.15 percent Mo.

37 Quartz Creek - Significant $\mathrm{Pb}$-Zn-Ag mineralization; reported grades of 15 percent combined $\mathrm{Pb}-\mathrm{Zn}$ and $10 \mathrm{oz} /$ ton $\mathrm{Ag}$.

38 Placer River - Significant Mo-F mineralization disseminated in intrusive rocks. Reported values of 0.2 percent Mo.

39 Candle Creek - Placer Au deposits with significant reserves. Placer concentrates reported to have significant $U$ and galena concentrations.

40 Poovookpuk Mountain - Porphyry Mo mineralization. Reported grades of up to 0.25 percent Mo.

41 Purcell Mountain - Mo and Ag occurrences associated with Cretaceous alkalic igneous plutons, alaskite, and bostonite dikes.

42 Koyukuk-Hughes mining district - Production of $230,000 \mathrm{oz} \mathrm{Au}$ from 1930 to 1975, mainly from Alaska Gold dredging operation at Hogatza; dredge reactivated in 1981, but deactivated in 1984. Nonfloat mechanized operation on Utopia Creek produced significant amount of placer Au from 1930 to 1962.

43 Flat mining district - Major placer Au district; produced $1,535,701$ oz Au through 1986. Potential exists for occurrence of significant lode-Au and lode-W reserves at Golden Horn deposit and other known lodes in region associated with shear zones and monzonite intrusive rocks of Late Cretaceous age.

43a Innoko-Tolstoi mining district - Major placer Au district with significant lode $\mathrm{Au}-\mathrm{Sb}-\mathrm{Hg}$ potential; lode sources for placers are volcanic-plutonic complexes of Late Cretaceous age and dike swarms that intrude Mesozoic flysch; mining district produced 582,432 oz Au from placer deposits. 
44 Nixon Fork - Promising Au-Cu deposits; Nixon Fork mine produced $57,000 \mathrm{oz}$ Au from Late Cretaceous skarns associated with quartz monzonite-Devonian limestone contact zones. Indicated reserve of 320,000 oz gold in 285,000 tons of ore.

44a Illinois Creek - Reserves (all categories) of 1.3 million tons at $0.093 \mathrm{oz} /$ ton gold and $1.84 \mathrm{oz} /$ ton silver, or 2.7 million tons of $0.059 \mathrm{oz} /$ ton gold and $1.60 \mathrm{oz} /$ ton silver.

45 Bonanza Creek - Skarn-type W mineralization along intrusive contact; no published information available.

46 Ruby mining district - Placer Au-Sn district; produced more than 420,000 oz Au from 1931 to 1960; mining district also contains $\mathrm{Pb}-\mathrm{Ag}$ prospects with grades reportedly as high as $82 \mathrm{oz} /$ ton $\mathrm{Ag}$.

47 Hot Springs mining district - Placer Au-Sn district; produced more than 450,000 oz Au and over 720,000 lb cassiterite through 1981. Includes Eureka and Tofty subdistricts.

48 Livengood-Tolovana mining district - Placer Au district; produced more than 448,000 oz Au since discovery in 1914. Substantial reserves remain.

49 Fairbanks mining district - Seventh largest Au-producing district in United States; largest producer in Alaska. Produced about $8,000,000 \mathrm{oz}$ Au from placer deposits. Major lode-Au and lode-Sb producer; produced more than $285,000 \mathrm{oz} \mathrm{Au}$ and over 4 million $\mathrm{lb}$ Sb from veins and shear zones through 1970. Production of $W$ exceeded 4,000 tons since 1915, all derived from tactite and skarn near Cretaceous quartz monzonite.

49a Fort Knox - Disseminated gold deposit within granodiorite/quartz monzonite pluton near Fairbanks. Prefeasibility study, 1990, indicates resource of 7.1 million oz, of which over 4 million oz may be recoverable from about 135 to 220 million tons of rock depending on the mining scenario.

49b Ryan lode - Complex shear zone with high-grade gash-veins in schist with estimated reserves to a depth of $200 \mathrm{ft}$ of 1.2 million tons. Work in 1990 identified the shear at a depth of 1,000 ft, and demonstrated a subparallel gold-bearing shear within monzodioritic igneous rocks open along strike and at depth, with estimated reserves to $100 \mathrm{ft}$ of 350,000 tons grading $0.077 \mathrm{oz}$ per ton.

49c Grant Mine - A series of subparallel gold-bearing quartz veins in the schist and quartzite of Ester Dome. Indicated reserves, 1990, on one vein system, the O'Dea, are 212,000 tons of $0.36 \mathrm{oz} /$ ton gold. Other similar vein systems have been identified within the property.

50 Mt. Prindle - Significant uranium rare earth mineralization in Mesozoic alkaline igneous rocks. Rock geochemical values of up to 0.7 percent uranium; up to 15 percent rareearth elements reported.

51 Iwin Mountain - Significant W mineralization associated with skarn development along contact zone of quartz monzonite stock of Cretaceous age.

52 Circle mining district - Currently Alaska's largest producing placer-Au district; produced 917,500 oz Au since discovery in 1893. Has significant potential for $\mathrm{Sn}, \mathrm{W}$, and Au mineralization from variety of lode sources.
53 Three Castle Mountain, Pleasant Creek, Casca VABM - Stratabound $\mathrm{Pb}-\mathrm{Zn}$ massive sulfide mineralization. Reported grades of up to 17 percent $\mathrm{Zn}$ and 2 percent $\mathrm{Pb}$.

54 Totatlanika River lode zone, Anderson Mountain, Dry Creek, Virginia Creek - Significant volcanogenic Cu-Pb-Zn-Ag massive sulfide deposits of Devonian to Mississippian age in Bonnifield mining district. Potential for high-grade deposits reported. Includes Liberty Bell strata-bound Au deposit and Sheep Creek; latter contains $\mathrm{Sn}$ and base metals.

55 Delta massive sulfide belt - Contains at least 30 known volcanogenic massive sulfide deposits and occurrences. Grades from 0.3 to 1.1 percent $\mathrm{Cu}, 1.7$ to 5.7 percent $\mathrm{Zn}, 0.5$ to 2.3 percent $\mathrm{Pb}, 0.7$ to $2.0 \mathrm{oz} / \mathrm{ton} \mathrm{Ag}$, and 0.018 to $0.061 \mathrm{oz} /$ ton $\mathrm{Au}$; estimated potential reserve of $\mathbf{4 0}$ million tons for all deposits.

56 Mosquito, Peternie - Porphyry Mo prospects of early Tertiary age; reported grades of up to 0.17 percent Mo.

57 Taurus - Major porphyry Cu-Mo prospect of Paleocene age with at least 500 million tons of mineralization. Reported potential for large tonnage of 0.5 percent $\mathrm{Cu}$ and 0.05 percent Mo.

58 Big Creek, Ladue - Strata-bound $\mathrm{Pb}-\mathrm{Zn}-\mathrm{Ag}$ massive sulfide prospects in metavolcanic rocks.

59 Slate Creek - At least 55 million tons of 6.3 percent, high-quality chrysotile asbestos in serpentinized ultramafic rocks of Permian(?) age.

60 Fortymile mining district - Major placer Au district. Produced over $501,000 \mathrm{oz}$ Au since discovery in 1886 .

61 Kantishna mining district - Major placer $\mathrm{Au}$ and lode $\mathrm{Ag}-\mathrm{Au}-\mathrm{Pb}$ $\mathrm{Zn}-\mathrm{Sb}-\mathrm{W}$ district. Produced more than 92,000 oz placer-Au, about $260,000 \mathrm{oz}$ lode $\mathrm{Ag}$, and several million lb Sb from shear zones and vein deposits hosted in Precambrian metamorphic units. Potential exists for significant Ag-Au-Pb-Zn deposits. Metalliferous strata-bound deposits occur in schist and quartzite.

62 Stampede mine - Major Sb deposit; produced more than 3.5 million lb Sb from large shear zone in Precambrian metamorphic rocks.

63 Coal Creek - Greisen-hosted Sn-Cu-W deposit in "McKinley" age pluton ( $55 \mathrm{Ma}$. old). Reported reserves of 5 million tons of ore that grade 0.28 percent $\mathrm{Sn}$ and 0.3 percent $\mathrm{Cu}$ with credits of $\mathrm{W}$, $\mathrm{Ag}$, and $\mathrm{Zn}$.

64 Golden Zone mine - Major $\mathrm{Au}-\mathrm{Cu}-\mathrm{Ag}$ deposits in Late Cretaceous breccia pipe. Produced more than $1,581 \mathrm{oz} \mathrm{Au}, 8,617 \mathrm{oz} \mathrm{Ag}$, and $42,000 \mathrm{lb} \mathrm{Cu}$. Estimated reserves are 230,000 contained ounces of gold.

65 Nim Prospect - Porphyry $\mathrm{Cu}-\mathrm{Ag}$-Au deposit of Late Cretaceous age. Reported grades of up to 5.0 percent $\mathrm{Cu}$ and $9 \mathrm{oz} / \mathrm{ton} \mathrm{Ag}$.

66 Valdez Creek - 316,000 ounces of proven and probable reserves plus 313,000 ounces of possible reserves in paleoplacer channels. 
67 Denali Prospect - At least six small, strata-bound Cu lodes in volcanic sedimentary rocks of Triassic age that may contain 5 million tons ore that grade about 2 percent $\mathrm{Cu}$ with credits of Ag.

68 Chistochina - Porphyry Cu prospects of Tertiary age and placerAu district; produced more than $177,000 \mathrm{oz}$ Au and small amount Pt from placer deposits.

69 Nabesna mine - Classic high-grade Au skarn that envelopes quartz diorite of Jurassic(?) age; produced over $66,960 \mathrm{oz}$ Au from about 88,000 tons of ore from 1930 to 1941 .

70 Spirit Mountain - Massive and disseminated Cu-Ni mineralization in mafic-ultramafic complex.

71 Kennecott deposits - Major stratiform Cu-Ag massive sulfide deposits localized near contact between Chitistone Limestone and Nikolai Greenstone of Triassic age; contained some of highest grade Cu lodes mined in North America. From 1911 to 1938, produced more than 1.2 billion $\mathrm{lb} \mathrm{Cu}$ and 10 million oz $\mathrm{Ag}$ from 4.8 million tons ore. Some reserves remain.

72 Binocular and other prospects - Kennecott-type $\mathrm{Cu}-\mathrm{Ag}$ massive sulfide deposits.

73 Bond Creek - Orange Hill - Two major porphyry Cu-Mo deposits of Late Cretaceous age; reported inferred reserves of 850 million tons ore that grade 0.3 to 0.5 percent $\mathrm{Cu}$ and 0.03 percent Mo.

74 Carl Creek - Porphyry Cu prospect in altered intrusive complex; similar to locality 73 .

75 Baultoff - Porphyry Cu prospect in altered intrusive rocks; inferred reserves of 145.1 million tons of 0.20 percent $\mathrm{Cu}$ similar to locality 73 .

76 Horsfeld - Porphyry Cu prospect; similar to locality 73.

77 Midas mine - Significant strata-bound $\mathrm{Cu}(\mathrm{Ag}-\mathrm{Au}-\mathrm{Pb}-\mathrm{Zn}$ ) massive sulfide deposit in volcanic sedimentary rocks of Tertiary Orca Group. Produced more than 3.3 million lb $\mathrm{Cu}$ from 49,350 tons ore.

78 Ellamar - Strata-bound Cu-Zn-Au massive sulfide deposit in sediment of Eocene(?) Orca Group. Produced more than 16 million $\mathrm{lb} \mathrm{Cu}, 51,307 \mathrm{oz} \mathrm{Au}$, and 1,91,615 oz Ag from about 301,835 tons ore.

79 Willow Creek, Independence, Lucky Shot, War Baby - Major lode-Au (Ag-Cu-Pb-Zn-Mo) in veins that cut Mesozoic quartz diorite. Produced more than $448,082 \mathrm{oz}$ Au from lode sources and about 35,000 oz Au from associated placer deposits.

80 Latouche, Beatson - Major strata-bound $\mathrm{Cu}-\mathrm{Zn}$-Ag massive sulfide deposits in Orca Group sedimentary rocks and mafic volcanic rocks. Produced more than 205 million lb $\mathrm{Cu}$ from 6 million tons ore. Inferred reserves of 4.53 million tons ore that grade 1 percent $\mathrm{Cu}, 1.5$ percent $\mathrm{Pb}+\mathrm{Zn}$, and $1 \mathrm{oz} /$ ton $\mathrm{Ag}$ may remain.

81 Rua Cove - Major strata-bound Cu-Zn massive sulfide deposit in complex ore shoots enclosed in mafic volcanic rocks of Orca Group. Reported reserves of over 1.1 million tons ore that grade 1.25 percent $\mathrm{Cu}$.
82 Red Mountain - Significant $\mathrm{Cr}$ occurrence associated with layered ultramafic complex of Tertiary age at Red Mountain near Seldovia. More than 36,000 tons metallurgical-grade ore shipped through 1976; huge low-grade chrome resource may remain, of which 30 million tons grade 5.1 percent $\mathrm{Cr}_{2} \mathrm{O}_{3}$.

83 Red Devil - Major Hg-Sb deposit; moderate-grade ore hosted in shear zones in Kuskokwim Group sedimentary rocks. More than 35,000 flasks $\mathrm{Hg}$ produced from 75,000 tons ore.

84 Nyac mining district - Significant placer Au district. Aniak mining district (of which Nyac is a part) produced more than 230,000 oz Au from placer deposits.

85 Goodnews Bay - Major placer Pt district; estimated to have produced over 540,000 oz refined Ptgroup metals from 1934 to 1976; one of the largest known Pt-group metal resources in United States. Possible reserves of 60 million yd' of deep, Ptbearing gravels remain. Lode source believed to be Alaskan-type zoned ultramafic complex of Cretaceous age.

86 Apollo-Sitka mines - Major lode Au deposits; produced more than $107,900 \mathrm{oz}$ Au from ore that averaged about $0.22 \mathrm{oz} / \mathrm{ton} \mathrm{Au}$. Inferred reserves may amount to 748,000 tons that grade $0.76 \mathrm{oz} /$ ton $\mathrm{Au}, 2.16 \mathrm{oz} \mathrm{Ag}$, and several percent base metal.

87 Pyramid - Late Tertiary porphyry Cu-Mo deposit; inferred reserves of 125 million tons ore that grade 0.4 percent $\mathrm{Cu}$ and 0.03 percent Mo reported.

88 Ivanof - Late Tertiary porphyry Cu prospect; grades of up to 0.72 percent $\mathrm{Cu}$ reported. Potential for large tonnages.

89 Weasel Mountain, Bee Creek - Porphyry Cu-Mo prospect of late Tertiary to Quaternary age; grades of up to 0.48 percent $\mathrm{Cu}$ and 0.035 percent Mo reported. Potential for moderate tonnages of low-grade mineralization.

90 Mike deposit - Porphyry Mo prospect of late Tertiary age; grades of up to 0.21 percent Mo reported. Potential for large tonnages of low-grade Mo mineralization.

91 Rex deposit - Porphyry Cu prospect similar to locality 90; grades of up to 0.3 percent $\mathrm{Cu}$ reported. Potential for moderate reserves of low-grade mineralization.

92 Kasna Creek - Major stratiform $\mathrm{Cu}-\mathrm{Pb}-\mathrm{Zn}$ and skarn-sulfide deposits of Mesozoic age in mafic, volcanic, and sedimentary rocks; reported reserves of over 10 million tons ore that grade more than 1 percent $\mathrm{Cu}$.

93 Sleitat Mountain - High grade grade east-west-trending, topazquartz-tin-tungsten greisen system hosted in $57 \mathrm{Ma}$. old binary granite and in hornfels. Zone up to 3,000-ft-long and 500-ft-wide. One drill hole showed $85 \mathrm{ft}$ of 1.8 percent tin, 0.4 percent tungsten.

94 limmy Lake - Complex Cu-Ag-Sn mineralization of late Tertiary(?) age; reported grades of up to $105 \mathrm{oz} /$ ton $\mathrm{Ag}$ and 3 percent $\mathrm{Cu}$.

95 Haines Barite - Major stratiform $\mathrm{Ba}-\mathrm{Pb}-\mathrm{Zn}-\mathrm{Cu}-\mathrm{Ag}$ deposit in pillow basalt-dominated section of Paleozoic or Triassic age; consists of 48- to 60-ft-thick zone of 60-percent barite with upper zone ( 2 to $8 \mathrm{ft}$ thick) of massive sulfides that contain 2 percent $\mathrm{Pb}, 3$ percent $\mathrm{Zn}, 1$ percent $\mathrm{Cu}, 2$ to $4 \mathrm{oz} / \mathrm{ton} \mathrm{Ag}$, and $0.12 \mathrm{oz} /$ ton $\mathrm{Au}$. Estimated to contain 750,000 tons of 65 percent barite with metal credits. 
96 Klukwan - Major Fe-Ti deposits in zoned ultramafic complex of Mesozoic age; reported to contain 3 billion tons of material that contain 16.8 percent $\mathrm{Fe}$ and 1.6 to 3.0 percent $\mathrm{Ti}$.

97 Nunatak - Porphyry Mo deposit; reported reserves of 8.5 million tons ore that grade 0.125 percent Mo and 129 million tons of 0.04 percent Mo.

98 Brady Glacier - Major Ni-Cu deposit in layered gabbro-pyroxenite complex of Tertiary age. Proven reserves of 100 million tons ore that grade 0.5 percent $\mathrm{Ni}$ and 0.3 percent $\mathrm{Cu}$ reported; also contains significant $\mathrm{Co}$ and $\mathrm{Pt}$ concentrations.

99 Mertie Lode and Funter Bay mining district - Contains substantial reserves of lode Au mineralization. Past production totaled 10,000 to 15,000 oz $\mathrm{Au}$. Deposits also contain significant $\mathrm{Ni}-\mathrm{Cu}$ and $\mathrm{Pb}$ $\mathrm{Zn}$-Ag mineralization. Funter Bay deposit contains reported reserves of 560,000 tons that grade 0.34 percent $\mathrm{Ni}, 0.35$ percent $\mathrm{Cu}$, and 0.15 percent $\mathrm{Co}$ in gabbropipe system.

100 Alaska-Juneau - Major lode Au deposit that consists of 100- to 300 ft wide zone that contains enechelon, gold-bearing quartz veins in metamorphic rocks; produced more than 3.52 million oz Au from 88.5 million tons ore from 1893 to 1944. Reserves (all categories), of 105.7 million tons of $0.05 \mathrm{oz} /$ ton gold remain.

101 Chichag of and Hirst Chichag of - Major lode-Au deposits in quartz veins that cut Mesozoic graywacke; produced more than $770,000 \mathrm{oz} \mathrm{Au}$. Chichag of mine produced about $700,000 \mathrm{oz} \mathrm{Au}$ and 200,000 oz Ag; Hirst Chichagof mine produced about $67,980 \mathrm{oz} \mathrm{Au}$ and $20,000 \mathrm{oz} \mathrm{Ag}$. Inferred lease reserves estimated to be $100,000 \mathrm{oz}$.

102 Mirror Harbor - Ni-Cu mineralization in layered gabbro complex of Mesozoic age; reported probable reserves of 8,000 tons of 1.57 percent $\mathrm{Ni}$ and 0.88 percent $\mathrm{Cu}$ and reported inferred reserves of several million tons ore that grade 0.2 percent $\mathrm{Ni}$ and 0.1 percent $\mathrm{Cu}$.

103 Bohemia Basin - Major Ni-Cu-Co mineralization in layered mafic complex similar to locality 102; reported reserves of 22 million tons ore that grade 0.33 to 0.51 percent $\mathrm{Ni}, 0.21$ to 0.27 percent $\mathrm{Cu}$, and 0.02 percent $\mathrm{Co}$.

104 Apex-El Nido - Significant lode Au-W deposits that occur as crosscutting veins in graywacke; produced more than $50,000 \mathrm{oz}$ $\mathrm{Au}$.

105 Greens Creek - Major sediment-hosted $\mathrm{Pb}-\mathrm{Zn}-\mathrm{Cu}-\mathrm{Ag}$-Au volcanogenic massive sulfide deposit of Devonian or Triassic age; most recent reserve estimate is about 17.5 million tons ore that grades about $25.3 \mathrm{oz} /$ ton $\mathrm{Ag}, 0.16 \mathrm{oz} /$ ton $\mathrm{Au}, 10.8$ percent $\mathrm{Zn}$, and 4.1 percent $\mathrm{Pb}$.

106 Sumdum - Volcanogenic Cu-Pb-Zn massive sulfide deposit in Mesozoic metamorphic complex with potential strike length of over 10,000 ft. Inferred reserves of 26.7 million tons ore that grade 0.57 percent $\mathrm{Cu}, 0.37$ percent $\mathrm{Zn}$, and $0.3 \mathrm{oz} /$ ton $\mathrm{Ag}$ reported.

107 Snettisham - Fe-Ti deposit in mafic zoned-intrusive complex; reported grades of about 18.9 percent $\mathrm{Fe}$ and 2.6 percent $\mathrm{Ti}$.

108 Tracy Arm - Strata-bound Cu-Zn-Pb massive sulfide prospect in Mesozoic schist; over $1,100 \mathrm{ft}$ long and up to $12 \mathrm{ft}$ thick. Reported grades of 1.5 percent $\mathrm{Cu}, 3.9$ percent $\mathrm{Zn}, 0.76 \mathrm{oz} / \mathrm{ton} \mathrm{Ag}$, and $0.013 \mathrm{oz} / \mathrm{ton} \mathrm{Au}$
109 Red Bluff Bay - Significant chrome mineralization in Mesozoic ultramafic complex (probably ophiolite); reported reserves of 570 tons of material that grade 40 percent $\mathrm{Cr}$ and 29,000 tons that grade 18 to 35 percent $\mathrm{Cr}$.

110 Cornwallis Peninsula - Volcanogenic Cu-Pb-Zn-Ag-Ba massive sulfide deposit of Triassic(3) age; reported grades of up to 20 percent $\mathrm{Pb}-\mathrm{Zn}$ and $23 \mathrm{oz} /$ ton $\mathrm{Ag}$.

111 Castle Island - Stratiform barite deposit of Triassic age hosted in carbonate and pillow basalt; about 856,000 tons of raw and refined barite produced from 1963 to 1980; also contains $\mathrm{Zn}, \mathrm{Pb}$, and $\mathrm{Cu}$ sulfides. Reported to be mined out.

112 Ground Hog Basin - Area contains several stratiform massive sulfide prospects in Mesozoic schist and gneiss whose origins are unknown. Reported grades of up to 8 percent $\mathrm{Pb}, 29 \mathrm{oz} /$ ton Ag, and $0.5 \mathrm{oz} /$ ton $\mathrm{Au}$. Area also contains potential for porphyry Mo deposits.

113 Snipe Bay - Ni-Cu deposit in zoned mafic-ultramafic complex; inferred reserves of 430,000 tons of 0.3 percent $\mathrm{Ni}, 0.3$ percent $\mathrm{Cu}$, and $0.13 \mathrm{oz} / \mathrm{ton} \mathrm{Ag}$ reported.

114 Kasaan Peninsula - Major skarn-type Cu-Fe-Au massive sulfide deposit of Jurassic age; area has produced over 28 million $\mathrm{lb} \mathrm{Cu}$ and 55,000 oz Ag. Reported reserves of 4 million tons ore that grade 50 percent $\mathrm{Fe}$ and less than 2 percent $\mathrm{Cu}$.

115 Salt Chuck - Cu-PGM-Ag-Au deposit in contact zone between pyroxenite and gabbro within Alaskan-type zoned maficultramafic pluton. From 1900 to 1941,5 million lb Cu, over $20,000 \mathrm{Oz}$ PGM, and $\mathrm{Au}$ and $\mathrm{Ag}$ credits were produced from 325,000 tons ore.

116 Union Bay - Significant Fe-Ti mineralization in ultramafic complex; area also contains $\mathrm{Pt}$ and $\mathrm{V}$ concentrations.

117 Hyder mining district - Area produced more than 25,000 tons high-grade W-Cu-Pb-Zn-Ag ore from 1925 to 1951 from crosscutting ore shoots in Texas Creek granodiorite of Tertiary age. Area also contains potential for porphyry Mo-W mineralization and massive sulfide-skarn $\mathrm{Pb}-\mathrm{Ag}-\mathrm{Au}-\mathrm{W}$ deposits.

118 Jumbo - Cu-Fe-Mo-Ag skam deposit; produced more than 10 million $\mathrm{lb} \mathrm{Cu}, 280,000 \mathrm{oz} \mathrm{Ag}_{8}$, and 7,000 oz Au from 125,000 tons ore from classic, zoned magnetite-Cu skarns associated with epizonal granodiorite pluton of Cretaceous age. Reported reserves of 650,000 tons ore that grade 45.2 percent $\mathrm{Fe}$, 0.75 percent $\mathrm{Cu}, 0.01 \mathrm{oz} /$ ton $\mathrm{Au}$, and $0.08 \mathrm{oz} /$ ton $\mathrm{Ag}$.

119 Copper City - Stratiform Cu-Zn-Ag-Au massive sulfide deposit hosted in late Precambrian Wales Group. Reported grades of up to 12.7 percent $\mathrm{Cu}, 2.7$ percent $\mathrm{Zn}, 2.5 \mathrm{oz} / \mathrm{ton} \mathrm{Ag}$, and $0.2 \mathrm{oz} / \mathrm{ton}$ Au.

120 Quartz Hill - World-class porphyry-Mo deposit in composite felsic pluton ( $25 \mathrm{Ma}$. old); proven reserves of 1.5 billion tons ore that grade 0.136 percent $\mathrm{MoS}_{2}$, including 490 million tons with grades of 0.219 percent $\mathrm{MoS}_{2}$.

121 Niblack - Volcanogenic $\mathrm{Cu}-\mathrm{Pb}-\mathrm{Au}-\mathrm{Ag}$ massive sulfide deposit hosted in Precambrian(3) Wales Group or Ordovician to Silurian Descon Formation; produced more than 1.4 million $\mathrm{lb} \mathrm{Cu}$, $11,000 \mathrm{oz} \mathrm{Au}$, and 15,000 oz $\mathrm{Ag}$. 
122 Bokan Mountain - Numerous U-Th prospects associated with Jurassic peralkaline intrusive complex; from 1955 to 1971 , produced more than 120,000 tons ore that graded about 1 percent $\mathrm{U}_{3} \mathrm{O}_{8}$. Also contains 40 million tons of 0.126 percent niobium and up to 1 percent REE metals.

123 Kemuk Mountain - Magmatic Fe-Ti deposit hosted in Cretaceous(?) pyroxenite. Inferred reserves of 2.4 billion tons that average 15 to 17 percent $\mathrm{Fe}, 2$ to 3 percent $\mathrm{TiO}_{2}$, and 0.16 percent $\mathrm{P}_{2} \mathrm{O}_{5}$.

124 McLeod - Porphyry Mo deposit that contains quartz-molybdenite fissure veins in quartz-feldspar porphyry. Chip samples contain up to 0.09 percent $\mathrm{Mo}$.

125 Johnson River - Epigenetic(?) quartz-sulfide stockwork or massive sulfide deposit hosted in volcaniclastic, pyroclastic, and volcanic rocks of Jurassic Talkeetna Formation. Average grades of 9.4 to 24.8 percent $\mathrm{Zn}, 2.8$ percent $\mathrm{Pb}, 1.7$ percent $\mathrm{Cu}$, and 0.6 to $1.2 \mathrm{oz} /$ ton Au reported.
126 Nimiuktuk River - Small hill of massive, high-grade barite estimated to contain at least 1.5 million tons barite. Widespread stream-sediment $\mathrm{Ba}$ anomalies in area indicate further barite potential.

127 Kensington - Stockworks of quartz veins in sheared and chloritized quartz diorite produced 10,900 tons grading $0.18 \mathrm{oz} /$ ton gold prior to 1930 . Estimated to contain at least 12.8 million tons grading $0.148 \mathrm{oz} /$ ton gold.

128 Jualin - Five quartz-fissure veins in Cretaceous quartz diorite, more than 15,000 ft of underground workings; produced 48,387 oz gold, mainly prior to 1930 . Reserves estimated at 1.07 million tons of $0.349 \mathrm{oz} /$ ton gold.

129 Pebble Beach - Cu-Au porphyry with identified resource of 200 million tons $0.4 \mathrm{Cu}$ with $0.012 \mathrm{oz} /$ ton gold, including 50 million tons 0.5 percent copper and $0.015 \mathrm{oz} /$ ton gold. Not yet fully explored.
Figure 44. Map showing significant copper, lead, zinc, $(+)$ silver, gold, and barite deposits in Alaska, 1990. (See appendix $D$ for deposit descriptions.)

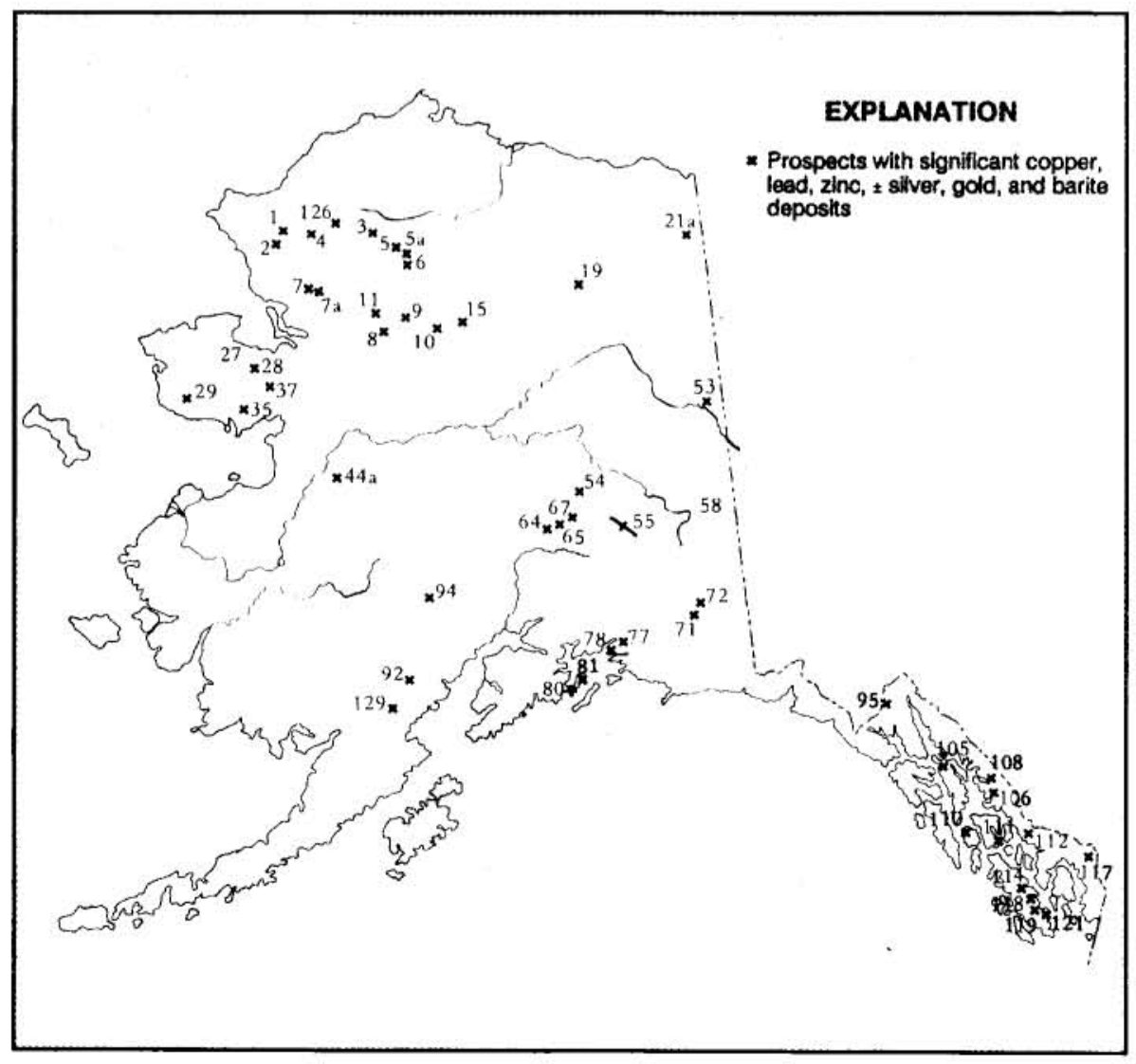



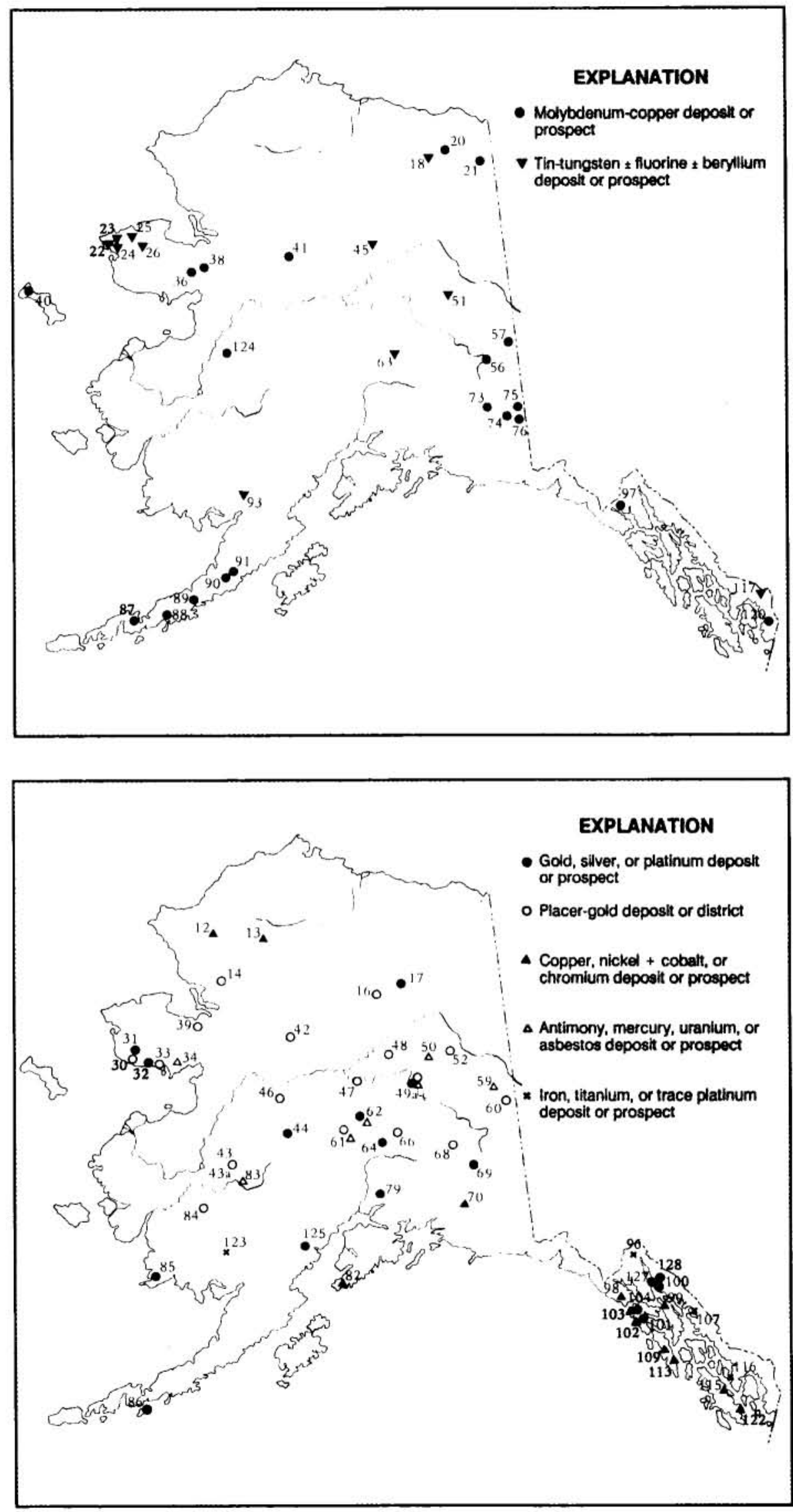

Figure 45. Map showing locations of significant molybdenum-copper, and tintungsten (+) fluorite and beryllium deposits in Alaska, 1990. (See appendix $D$ for deposit descriptions.)

Figure 46. Map showing significant gold, silver, platinum, and strategic mineral deposits in Alaska, 1990. (See appendix $D$ for deposit descriptions.) 


\section{APPENDIX E \\ Mining licenses issued by Alaska Department of Revenue, 1990}

\author{
ADD-VENTURES LTD. \\ 720 M St., Ste. 200 \\ Anchorage, AK 99501 \\ ALASKA AGGREGATE CORP. \\ John L. Brewer (3) \\ 240 West 68 th Ave. \\ Anchorage, AK 99518 \\ (sand and gravel) \\ ALASKA GOLD CO. \\ Alice E. Bayless \\ P.O. Box 28 \\ Chicken, AK 99732 \\ ALASKA GOLD CO. \\ Roy Ferrenbach \\ 1215 Bunnell, Apt 11 \\ Fairbanks, AK 99712 \\ ALASKA GOLD CO. \\ Joseph F. Fisher (2) \\ P.O. Box 640 \\ Nome, AK 99762

\section{ALASKA GOLD CO.} \\ Al Hopen (2) \\ P.O. Box 1170 \\ Fairbanks, AK 99707 \\ ALASKA GOLD HARVESTORS \\ Philbin, Brad/Michelson, Lloyd \\ P.O. Box 875305 \\ Wassila, AK 99687 \\ ALASKA LIME CO. \\ James Caswell \\ P.O. Box 196 \\ Cantwell, AK 99729 \\ (limestone)
}

ALASKA PLACER DEVELOPMENT

Kart Hanneman (2)

P.O. Box 81467

Fairbanks, AK 99708

\section{ALASKA VENTURES}

Morris Wolters

622E SR4

Cuthlamet, WA 98612

\section{ALBERT CREEK MINING}

Calvin W. Hutcheson

P.O. Box 33

Eagle River, AK 99577-0033

ALEUTIAN MATERIALS

P.O. Box 1188

Woodinville, WA 98072

(sand and gravel)

\author{
AMAX GOLD EXPLORATION INC. \\ Edward Montgomery \\ 350 Indiana St. \\ Golden, CO 80401 \\ AMERICAN ARCTIC CO.
Rodky MCDonald
P.O. Box 81035
Fairbanks, AK 99708 \\ GERALD IRVIN ANDERSON \\ P.O. Box 362 \\ Anchorage, AK 99515 \\ BEAVER LOOP SAND \& GRAVEL \\ Mary Doyle \\ HCO1 Box 1225 \\ Kenai, AK 99611 \\ (sand and gravel) \\ BEEHIVE MINING \\ Layne Gardner \\ 1967 Yankovich Rd. \\ Fairbanks, AK 99709 \\ WILLIAM J. BEERMAN \\ 2416 S 1st St. \\ Yakima, WA 98901
}

WAYNE \& RANDI ANDERSON

1901 Cheechako Dr.

Fairbanks, AK 99709

ANNABELLE MINE

James Roland

710 McGrath Rd.

Fairbanks, AK 99712

ADAM ARNAVIAK SR

P.O. Box 95

Togiak, AK 99678

ARNESON CRUSHING

Menwin Arneson

P.O. Box 737

Palmer, AK 99645

(sand and gravel)

\section{ASSOCIATED CONSTRUCTION}

Joseph J. Rollins (2)

P.O. Box 266

Anchor Point, AK 99556

(sand and gravel)

AURORA MINING

Lester Lines

P.O. Box 10-3820

Anchorage, AK 99510

AURORA MINING

Schafer, Beatrice/Russell, Terry

P.O. Box 55074

North Pole, AK 99705

\section{AURORA MINING DBA}

LESTER LINES

Charles Wentworth Cleveland

P.O. Box 10-3820

Anchorage, AK 99510

PAUL BARELKA (3)

1215 9th Ave.

Fairbanks, AK 99701

TOD BAUER

P.O. Box 871502

Wasilla, AK 99687
TERESA ROXANNE BELL

Box 552

Coopers Landing, AK 99572

BEN GILLETTE ESTATE

Bert Pettigrew

P.O. Box 1230

Nome, AK 99762

RHINEY BERG

P.O. Box 809

Fairbanks, AK 99707

ARTHUR \& JEANNE BERGLUND

HC 1 Box 62755

Palmer, AK 99645

BIG G MINING, INC.

Hank Gradney

P.O. Box 74400

Fairbanks, AK 99707

STEVEN BILLS

Box 101

Eagle, AK 99738

RUSSELL L. BIRDSELL

P.O. Box 1908

Cave Creek, AZ 85331

B J MINING

Jack Zupan

P.O. Box 82911

Fairbanks, AK 99708

PATRICK BLISS

711 H St., Ste. 450

Anchorage, AK 99501

ROBERT WAYNE BLONDEAU

P.O. Box 602

Valdez, AK 99686

BLUE WATER MINING

Harold Nevers

8148 Pinewood Dr.

Juneau, AK 99738
BOULDER CREEK MINING CO.

Dorothy Fickes

P.O. Box 72618

Fairbanks, AK 99707

GLENN \& LELA BOUTON

665 Farmers Loop Rd.

Fairbanks, AK 99712

CARL A. BRACALE, JR.

733 W. 4th Ave., $\# 605$

Anchorage, AK 99501

KEHAULANI BELFIELD \&

JOHN BRENNAN

P.O. Box 74875

Fairbanks, AK 99707

ROBERT BRILEY

P.O. Box 72335

Fairbanks, AK 99707

BROAD PASS MINING CO.

Jesse D. Smith

P.O. Box 1070

Willow, AK 99688

DONALD BROWN

Box 1313

Kenai, AK 99611

(sand and gravel)

JOHN BROWN

1689 Goldstream Rd.

Fairbanks, AK 99709

MIRIAM BROWN

Box 1313

Kenai, AK 99611

(sand and gravel)

ROBERT BROWN

P.O. Box 2947

Soldotna, AK 99669

OPAL BRUHN

P.O. Box 8022

Nikiski, AK 99635

NORMAN BUCY

3638 Dunkirk Ct.

Anchorage, AK 99502

JOHN R. BURNS

P.O. Box 5

Chicken, AK 99732

BUSHMASTER MAN CO. Jimmy Schneider

Box 774407

Eagle River, AK 99577 
CAMP CREEK MINING Alvin and Eric Kile Box 140424

Anchorage, AK 99514

CANADA TUNGSTEN MINING CO. LTD.

Tungsten, Inc.

1600-1066 West Hastings St.

Vancouver, BC V6E 3X1 Canada

CANDLE MINING CO.

Kenneth R. Upchurch

8810 Rendon Dr.

Anchorage, AK 99507

CARLO \& SONS MINING

2113 Southern

Fairbanks, AK 99701

ROBERT DENNIS CARLSON

17732 A. James Wy.

Eagle River, AK 99577

\section{CASTLE CREEK MINES}

Fred R. Hall

P.O. Box 72037

Fairbanks, AK 99701

CENTRAL ALASKA EXPLORATION CORP.

Robin S. Tolbert

2173 University Ave. S.

Fairbanks, AK 99709

ELLIS DUANE CHAMBLISS

P.O. Box 31

Chicken, AK 99732

CHICKAMAN MINING CO.

Earl Schene

Box 66

Chicken, AK 99732

IIM CHILDS

P.O. Box 56587

North Pole, AK 99705

CIRCLE MINING CO.

Frank R. Warren (2)

P.O. Box 11

Central, AK 99730

CITIGOLD ALASKA INC.

Robert Emerson

3400 International Wy., Ste. B

Fairbanks, AK 99701

CLARA BEA INC.

B.W. Comstock (2)

P.O. Box 853

Kotzebue, AZ 99752

DOUGLAS M. CLARK

711 H St., Ste. 450

Anchorage, AK 99501

$\begin{array}{ll}\text { CLOUD/BELL } & \text { CROOKED DOG MINING } \\ \text { Joe Cloud } & \text { Charles/Henshaw, Byron, Bames } \\ \text { HC } 001 \text { Box } 875 & \text { P.O. Box } 193 \\ \text { Kenai, AK } 99611 & \text { Cantwell, AK } 99729\end{array}$

ROBERT J. COLZANI

P.O. Box 1955

Nome, AK 99762

COMINCO ALASKA INC.

P.O. Box 1230

Kotzebue, AK 99752

(lead and zinc)

COMINCO ALASKA

EXPLORATION

M. A. Millholland (3)

5660 B St.

Anchorage, AK 99518

COMINCO ALASKA

EXPLORATION

Phil St. George

139E 51st Ave.

Anchorage, AK 99503

COMPASS MINING CO.

John B. Hall

P.O. Box 2700

Fairbanks, AK 99707

CARL CONGDON

925 Commerce St.

Fairbanks, AK 99709

FREDERICK COOK

269 1/2 Richardson Hwy

Delta Junction, AK 99737

RICHARD COOK

2000 Sturbridge Circle

Anchorage, AK 99507

COOK'S MINING

John Cook (2)

P.O. Box 70393

Fairbanks, AK 99707

FRED G. CORNELIUS

1615 Madison Dr.

Fairbanks, AK 99709

FRANK COUCH

149 Famsworth

Soldotna, AK 99669

CRISWELL MINING \& EXPLORATION

Herbert F. Fassler

Box 670181

Chugiak, AK 99567

W.R.C. CROLEY

Ole Olson

P.O. Box 191

Tok, AK 99780
VERL DOUGLAS CUSHMAN, SR. Rt 3, Box 1

Blackfoot, ID 83221

D \& J MINING

David Penz

Box 29

Russian Mission, AK 99657

JIMINMAN, JIM DEAL

HCO2 7630

Palmer, AK 99645

DELIMA PLACERS

Don P. Delima

Manley Hot Springs, AK 99756

DEPEM

Donald Stein

105 Dunbar Ave.

Fairbanks, AK 99701

LESLEY DEVORE

P.O. Box 74

Chicken, AK 99732

JOHN T. DEWAN

P.O. Box 870257

Wasilla, AK 99687

ROY A. DIEHL

General Delivery

Anchorage, AK 99501

DOME CREEK MINING

Richard Stough

General Delivery

Chicken, AK 99732

RODERICK DUNN

Box 350

Talkeetna, AK 99676

RICHARD DUTHIE

P.O. Box 1920

Fairbanks, AK 99701

EARIY WINTERS MINING CO.

Lee G. Wilson

3605 Arctic $\$ 988$

Anchorage, AK 99503

JUDD EDGERTON

HC01 Box 6937-V

Palmer, AK 99645

ED'S GRAVEL PIT

Joanna Hollier

P.O. Box 366

Kenai, AK 99611

(sand and gravel)
EEP'S EQUIPMENT RENTALS

\& MINING

Allan G. Anderson

Dog St.

Takotna, AK 99675

EMPIRE EXPLORATION INC.

Dennis Garrett

P.O. Box 142593

Anchorage, AK 99514

KRISTER ERIKSSON

P.O. Box 872809-199

Wasilla, AK 99678

TOM ERICKSON

General Delivery

Eagle, AK 99738

DANIEL L. EVEN

P.O. Box 82092

Fairbanks, AK 99708

THOMAS E. FAA

SR MP 260 Parks Hwy.

Healy, AK 99743

FAIRBANKS EXPLORATION INC.

Kelly Dolphin

Curtis J. Freeman (15)

P.O. Box 82549

Fairbanks, AK 99708

FAIRBANKS GOLD CO.

James Pray

P.O. Box 102792

Anchorage, AK 99510

FAIRBANKS GOLD INC.

Electrum Resources Corp.

394 Hamilton Ave.

Fairbanks, AK 99701

FAIRBANKS GOLD INC.

Daniel Nye

355 Burard St., Ste. 2100

Vancouver BC Canada V6C 2G8 or

P.O. Box 73726

Fairbanks, AK 99707-3726

FAIRBANKS SAND \&

GRAVEL, INC.

P.O. Box 1511

Fairbanks, AK 99707

(sand and gravel)

FAIRVIEW MINING CORP.

Edward Mooney

6711 Foothills Dr.

Anchorage, AK 99504

HERBERT F. FASSLER

P.O. Box 670181

Chugiak, AK 99567 
FINNBEAR MINING \&

EXPLORATION CO.

Arne Murto

P.O. Box 850

Kasilof, AK 99610

FLAT CREEK MINING CO.

James $P$. Haggland

P.O. Box 81464

Fairbanks, AK 99708

FLAT CREEK PLACERS

John E. Fullerton

General Delivery

Flat, AK 99584

FLAT PICK MINING

Gordon Fulton

P.O. Box 118

Central City, AK 99730

MITCH FLEMING

P.O. Box 9102

Coldfoot, AK 99701

JAMES, SR. \& SHARON FOGARTY

3034 Dyke Rd.

North Pole, AK 99705

FOUR BROTHERS MINING

Hery Clark Billings

P.O. Box 81117

Fairbanks, AK 99708

40 MILE MINING CO.

William Morris

P.O. Box 33

Chicken, AK 99732

45 PUP MINING

Charles R. Hammond

P.O. Box 7

Chicken, AK 99732

PATRICIA S. FRANKLIN

1213 Coppet

Fairbanks, AK 99709

FRANKLIN EXPLORATION

MINING CO.

Oliver Reese

1601 Eim St., Ste. 2364

Dallas, TX 75201

\section{FREEDOM MINING \&}

EXPLORATION

Roy Ruble

1985 Becker Ridge

Fairbanks, AK 99708

CURTIS J. FREEMAN

P.O. Box 74261

Fairbanks, AK 99707

LYNDON FUNK

Old Chena Hot Springs Rd

Box 362

Fairbanks, AK 99712
G.A. HANKS \& SONS

Harold Hanks

Box 2533, Hwy. 16

West Sacramento, CA 95691-2098

MARK GAEDE

P.O. Box 2192

Soldotna, AK 99669

PAUL \& ANN GAPEN

510 Cottonwood

Cheyenne, WY 83002

MICHAEL E. GEBHARD

5500 Whispering Spruce Dr.

Anchorage, AK 99516

STANLEYM. GELVIN

P.O. Box 30149

Central, AK 99730

ROY GEORGE

1334 San Blanco Dr.

Salinas, CA 93901

GEOSEARCH INC.

Stan Goss

7920 King St.

Anchorage, AK 99518

GERAGHTY MINING

Richard Geraghty

405 Juneau St.

Fairbanks, AK 99701

GERALD W. HOOPER \& ASSOC.

P.O. Box 875272

Wasilla, AK 99687

GERMANICA INC.

Mark Krenzke

635 Depaum Dr.

Fairbanks, AK 99707

GIRDWOOD MINING CO.

Gary McCarthy

P.O. Box 1089

Girdwood, AK 99587

CARL \& DESSIE GLANVILLE

HCR Box 1195

Anchor Point, AK 99556

GLOBAL RESOURCES INC.

Massie Perry

Box 1042

Nome, AK 99762

GOLD DUST MINES

D.M. Adkels (2)

P.O. Box 72151

Fairbanks, AK 99707

GOLDIGGERS

M. Annette Staton

3515 Industrial Ave.

Fairbanks, AK 99701
GOLDPOST MINING CO.

Richard Lindsten

P.O. Box 25

Hubbardston, MA 01452

GOLDSTREAM MINING INC.

John Larson

P.O. Box 80772

Fairbanks, AK 99708

CLYCE BALDWIN \&

BRANT GOODALL

P.O. Box 8

Chicken, AK 99732

RICHARD GOODSON

Box 12

Chicken, AK 99732

WALLACE E. GORDON

3035 Madison Wy.

Anchorage, AK 99508

GRATEFUL DOG MINING

Roger McPherson

1563 Jones Rd.

Fairbanks, AK 99709

GREAT NORTHERN MINING \& EXPLORATION

Douglous Nicholson

3865 Ulirbahn

Fairbanks, AK 99709

GREEN MINING \& EXPLORATION

Timothy Green

P.O. Box 61455

Fairbanks, AK 99706

STEVE GREENE

P.O. Box 60662

Fairbanks, AK 99706

RICHARD GREER

4400 Many Tell Ave.

Anchorage, AK 99516

SCOTT GREGER

P.O. Box 101

Red Devil, AK 99656

GYPSY LUCK MINING CO.

Glen and Shirley Parr

Route 1 MP 260

Healy, AK 99743

ALBERT M. HAGEN

P.O. Box 53

Manley Hot Springs, AK 99756

HAMMINING CO.

Harold Mitchell

P.O. Box 65

Chicken, AK 99732

HAROLD PARKER \&

JAMES HANSON, JR.

P.O. Box 195

Talkeetna, AK 99676
HARDSHIP MINING CO.

Donald R. Gates

2501 Lake Otis Pkwy.

Anchorage, AK 99508

EVERETT HARRIS

P.O. Box 962

Delta Junction, AK 99737

HARRISON CREEK MINING CO.

P.O. Box 61185

Fairbanks, AK 99706

DONALD/BALDWIN

CLYDE HART

P.O. Box 22

Chicken, AK 99732

MICHAEL GEORGE HARTMAN

P.O. Box 74921

Fairbanks, AK 99707

PETER HASSON

P.O. Box 13-171

Trapper Creek, AK 99683

EDWIN HATCH

Box 1801

Nome, AK 99762

HAYDEN EXPLORATION

\& MINING

Forest A. Hayden

P.O. Box 110930

Anchorage, AK 99511

HEALINGER MINING CO.

James R. Healey

P.O. Box 210212

Auke Bay, AK 99821

HECLA MINING CO.

6500 Mineral Dr.

Coueur D'Alene, ID 83814

HEFLINGER MINING

\& EQUIPMENT

Carl F. Heflinger

665 10th Ave., \# 307

Fairbanks, AK 99701

JACK HENDRICKSON

Box 10154

Fairbanks, AK 99710

CLYDE HENDRY

1271 9th Ave., Apt. 206

Fairbanks, AK 99701

HERICKS \& BELFIELD

James W. Belfield

P.O. Box 1934

Fairbanks, AK 99707

MARTIN M. HERZOG

14250 Sabine St.

Anchorage, AK 99516 
HILDRE SAND \& GRAVEL CO. Chuck Porter

Box 270

Juneau, AK 99802

(sand and gravel)

HOFFMAN MINING

Russell Hoffman

HC60 Box 153

Copper Center, AK 99573

HOLITNA BASIN MINING \& EXPLORATION

Mark Farrar

P.O. Box 1032

Hood River, OR 97031

HOLLYWOOD ROAD SAND \& GRAVEL

William Elkins

HC 30, Box 12860

Wasilla, AK 99687

(sand and gravel)

CARSON HOLT

P.O. Box 284

Ester, AK 99725

HOMER \& WILLIAM

HOOGENDORN

Box 84

Nome, AK 99762

HOPE MINING CO.

A. Johnson

P.O. Box 101827

Anchorage, AK 99510

CONRAD H. HOUSE

924 Kellum St., \#101

Fairbanks, AK 99701

HUNTER CREEK MINE

Steve M. Losonsky

P.O. Box 80321

Fairbanks, AK 99708

INGLE CREEK MINING

Gordon Kukowski

Box 6

Chicken, AK 99732

INMACHUK GOLD CORP.

Joh Peckenpaugh

928 Morning Side Dr.

Twin Falls, ID 83301

INTERIOR ALASKANA ASSOC.

Richard L. Loud

742 Bennet Rd.

Fairbanks, AK 99712

IAB DEVELOPMENT

Jeff Raymor

1665 Eagle River Rd., HC 83

Eagle River, AK 99577
JACKSON MINING CO.

Roy E. Traxler

936 Coppet St.

Fairbanks, AK 99709

J.B.R. INC.

David Ritter

P.O. Box 32292

Juneau, AK 99803

DANIEL JENSEN (3)

Box 12

Delta Junction, AK 99337.2098

OVERTON JILES

5250 Auburn-Folsom Rd.

Loomis, CA 95650

IIMMAR MINING VENTURES

James Luhrs, Ir. and Marua Dejong

3333 Lake Shore Dr. \#8

Anchorage, AK 99517

CURTIS JOHNSON

602 Stewart St.

Fairbanks, AK 99701

KARL J. BASSETT \&

DELL E. JOHNSON

P.O. Box 61537

Fairbanks, AK 99706

TOMMY \& MYRTLE JOHNSON

P.O. Box 608

Nome, AK 99762

JONES \& CO.

Jones W. Deering (2)

P.O. Box 1120, HCR 68

Moose Pass, AK 99631

KEN JOUPPI

2294 Walrus Ct.

North Pole, AK 99705

KACHEMAK MINING CORP.

Robert C. Busby

47660 Falls Creek Dr.

Homer, AK 99603

RICHARD D. KARR

P.O. Box 60782

Fairbanks, AK 99706

K.C. MINING CO.

Kenneth C. Hanson

P.O. Box 10657

Fairbanks, AK 99710

KDT EXPLORATION

\& MINING CO.

Kevin Thompson

P.O. Box 875534

Wasilla, AK 99687

ROBERT W. \& SUSAN J. KELLER

Box 113

Healy, AK 99743
KELLY MINING

Timothy Joseph Kelly

General Delivery

Manley, AK 99756

KENNECOTT EXPLORATION INC.

Walter Meyers

4600 Kietzke, Bldg. L-230

Reno, NV 89502

KIANA CORP

Debra Schnabel

P.O. Box 129

Haines, AK 99827

(sand and gravel)

KIN-ALASKA

Bob Flounders

3331 E. Huffman Rd.

Anchorage, AK 99516

SUSAN KNAPMAN

P.O. Box 71273

Fairbanks, AK 99707

KERRY LYNN KNAPP

P.O. Box 74124

Fairbanks, AK 99707

RICHARD KNUDSON

P.O. Box 210168

Anchorage, AK 99521

SAM KOPPENBERG

P.O. Box 130

Denali, AK 99755

T.J. KOPPENBERG

HCO4-9068

Palmer, AK 99645

LAWRENCE KORDECKI (2)

300 Howland Rd., \#3

Fairbanks, AK 99712

JAN KRALIK

Box 1793

Nome, AK 99762

KRISTI-PHYLEE

James Parry

P.O. Box 71656

Fairbanks, AK 99701

RUDY W. KRIZAK

General Delivery

Nome, AK 99762

KURT'S CONSTRUCTION

Kurt Ueeck

1900 Granite View Dr.

Delta Junction, AK 99737

(sand and gravel)

JACK LACROSS

P.O. Box 331

Soldotna, AK 99669
LAKBEY INC.

S. Allen Vezey

1216 Range View Rd.

North Pole, AK 99705

LAKEVIEW ENTERPRISE INC.

Philip Rahoi

1000 Lakeview Terrace Dr.

Fairbanks, AK 99701

(sand and gravel)

HOWARD LAMBERT

P.O. Box 87

Ester, AK 99725

JUANITA R. LARSON

9499 Brayton Dr. \#116

Anchorage, AK 99507

LAST CHANCE MINING CO.

Walter Roman

Illinois St.

Fairbanks, AK 99707

LAST HOPE MINING

Donald Lasley

P.O. Box 84438

Fairbanks, AK 99708

HARRY JOINES \& STELLA

DARLENE LAVENDER

General Delivery

Boundary, AK 99790

LAW IOSUAGOLDEN SLIPPER II

Joe Hall

711 Hillarest

Fairbanks, AK 99712

L \& B MINING

D.B. Parent

1015-10th Ave.

Fairbanks, AK 99701

LBMB MINING CO.

Robert Bornand

1536 W. Marinette

Exeter, CA 93221

L \& R MINING

Ted Hale Leonard

Box 51

Saicha, AK 99714

RAYLESTER

732 Old Steese Hwy., \#8

Fairbanks, AK 99712

BILL \& CLARA LIGHT

P.O. Box 74804

Fairbanks, AK 99707

DAVID W. LIKINS

P.O. Box 106

Eagle, AK 99738 


\section{LILLIAN CREEK MINE INC \\ Ronald Tucker \\ Box 60334 \\ Fairbanks, AK 99706 \\ GEORGE LIVERMORE \\ 3302 Dorbrandt, \#4 \\ Anchorage, AK 99503}

FRANK GEORGE LOCHNER

2825 Opal Ave.

Fairbanks, AK 99709

LONE SPRUCE MINING

George Strickler

General Delivery

Boundry, AK 99790

LONESOME MINING CO.

Charles Timothy Jackson

SR Box 2893GG

Wasilla, AK 99687

RICHARD LOUD

742 Bennet Rd.

Fairbanks, AK 99712

LINDON LOUDERMILK

10441 Loudermilk Circle

Anchorage, AK 99516

JAMES LOUNSBURY

P.O. Box 983

Fairbanks, AK 99707

MARIN LOVUS

2326 St Elias Dr.

Anchorage, AK 99517

LUCKY CREEK MINE LTD. PARTNERSHIP

Claude Morris

P.O. Box 547

Girdwood, AK 99587

LUCKY 7 MINING CO.

Ronald Roman

P.O. Box 71614

Fairbanks, AK 99707

LYLE COLLEDGE

P.O. Box 60478

Fairbanks, AK 99706

LYMAN RESOURCES IN

ALASKA INC.

Spencer Lyman

P.O. Box 192

McGrath, AK 99627

MAGIC CIRCLE MINING

Stephen Weber

332 Slater Dr.

Fairbanks, AK 99701
MAGNUM RESOURCES

INTL. INC.

Lawrence D. Wood

1900 Foundry Wy.

Wasilla, AK 99687

MAGNUSON MINING CO.

Warren Magnuson

P.O. Box 55

McGrath, AK 99627

ALBERT (MICK) MANNS

MINING CO.

Paradise Valley

Bettles, AK 99726

NIKOLAI MARCHUK

P.O. Box 89

Delta Junction, AK 99737

MARTIN MINING CO.

Edward Martin

P.O. Box 521

Cooper Landing, AK 99572

CLEON MARTINSON

7204 227th Place SW

Mt. Lake Terrace, WA 98043

DOUGLAS MARTINSON (8)

P.O. Box 52

Nome, AK 99762

ELMER MARTINSON (2)

P.O. Box 452

Nome, AK 99762

MARVEL DOME MINING CO.

Mark Matter

P.O. Box 44

Aniak, AK 99557

MASCOT MINING INC.

Thomas Bryant

County Rd. One

P.O. Box 264

Ridgway, CO 81432

DIANE MATHISEN

2261 Belmont Dr.

Anchorage, AK 99517

MAT-SU AGGREGATE

Merwin Arneson

P.O. Box 737

Palmer, AK 99645

(sand and gravel)

MAXWELL MINE \&

EXPLORATON

Leslie Maxwell

3910 Loc Sault Ave.

Anchorage, AK 99516

RICHARD MCCALLUM

Box 70138

Fairbanks, AK 99707
ORVAL MCCORMMACH

P.O. Box 15

Manly Hot Springs, AK 99756

MCGRAW'S GRAVEL SALES INC.

Dormand McGraw, Jr.

P.O. Box 185

Sitka, AK 99835

(sand and gravel)

HOWARD MCWILLIAMS

P.O. Box 221603

Anchorage, AK 99522

KEITH MENDENHALL

P.O. Box 1406

Fairbanks, AK 99707

MESPELT \& ALMASY MINING CO.

Theodore Almasy

Nixon Fork Mine

McGrath, AK 99627

METCO INC.

Frank Dieckgraeff

HCR 64, Box 300

Seward, AK 99664

(sand and gravel)

RUSS MILLER

5955 Liberty Ct.

Wasilla, AK 99687

MILLER CREEK MINING CO.

Fred D. Wilkinson

P.O. Box 1

Central, AK 99730

MINEX ALASKA INC.

Yoram Palkovitch

P.O. Box 103

Girdwood, AK 99587

ANDREW MISCOVICH (2)

Box 162

Fairbanks, AK 99707

JOHN MISCOVICH (2)

General Delivery

Flat, AK 99584

MISCOVICH MINING CO.

Howard Miscovich

P.O. Box 262

Galena, AK 99741

LARRY MOLLING

3025 E. 15th Ave.

Anchorage, AK 99508

MELVIN/LOIS MONTGOMERY

1836 Davenport Rd.

Delta Junction, AK 99737

GERALD HASSEL \&

ROGER MOORE

288 Rumbling Rd.

Fairbanks, AK 99712
KENNETH BARNES \& ANDREW MORITZ

254 River Rd.

Chehalis, WA 98532

WILLIAM MORGAN (2)

600 West 58th Unit J

Anchorage, AK 99518

MOSQUITO MINERS

David C. Haase

P.O. Box 83478

Fairbanks, AK 99708

DAVID MOSS

P.O. Box 681

Tok, AK 99780

MRAK PLACER MINE

William Mrak

P.O. Box 1963

Palmer, AK 99645

JACK MURPHY

P.O. Box 825

Valdez, AK 99686

NANA REGIONAL CORP. (2)

4706 Harding Dr.

Anchorage, AK 99517

N.B. TWEET \& SONS

Cheryl Jong

P.O. Box 503

Teller, AK 99727

N.B. TWEET \& SONS

Douglas Tweet (2)

Box 503

Teller, AK 99778

NERCO EXPLORATION CO.

Vincent Monzulla

2920 Monzulla Lane

Fairbanks, AK 99712

JACK NEUBAUER

General Delivery

Fairbanks, AK 99701

NEWMONT EXPLORATION LTD. 1 United Bank CTR 1700 Lincoln

Denver, CO 80203

FRED NODEN

P.O. Box 47

Dillingham, AK 99576

NORAM MINING INC.

John Jacobsen

308 G St., Ste. 209

Anchorage, AK 99501

WILLIAM NORDEEN

P.O. Box 9013

Coldíoot, AK 99701 
ROGER NORDLUM

Box 171

Kotzebue, AK 99752

NORTH STAR INVESTMENT CO.

Doris Coiner

P.O. Box 157

Cantwell, AK 99729

NORTHERN LIGHTS

MINING INC.

544 North 600 West

Cedar City, UT 84720

ROSS NOVAK (2)

P.O. Box 83200

Fairbanks, AK 99708

NUGGET MINING CO.

John Terwilliger

Box 92 Mile

1316 AK Highway

Tok, AK 99780

NYACMINING

Tuluksak Dredging Ltd.

737 E St.

Anchorage, AK 99501

DANIEL NYE (2)

1733 University Ave., Apt. F-10

Fairbanks, AK 99709

FRANKLIN O'DONNELL

7110 Canaday Rd.

Salcha, AK 99714

ALAN OLSON

Candle, AK 99728

STEVEN OLSON

P.O. Box 82330

Fairbanks, AK 99708

OMEGA MINING CO.

Richard Ott

P.O. Box 2748

Fairbanks, AK 99707

ONLINE EXPLORATION SERVICES

Kevin Adler

11976 Wildemess Dr.

Anchorage, AK 99516

RICHARD OSBORNE

P.O. Box 5210

Madison, WI 53705

JAMES WALKER \& DANA OSTLER

2021 Pembroke St.

Anchorage, AK 99504

OUTSIDER MINING CO.

John Trautner

Box 909

Girdwood, AK 99587
PACIFIC MINING INC.

James Stone

1300 E. 74th

Anchorage, AK 99518

TOMMY PARTEE

Box 607

Sterling, AK 99672

CACY PATTON

P.O. Box 1505

Fairbanks, AK 99707

PAUL \& CO.

George R. Homer

P.O. Box 60610

Fairbanks, AK 99707

PAUL \& CO.

Paul Manuel

Box 83102

Fairbanks, AK 99708

DAVID PENZ

Box 29

Russian Mission, AK 99657

WAYNE PEPPLER

1006 22nd St.

Fairbanks, AK 99701

ROY PHILPOTT

115 Charles St.

Fairbanks, AK 99701

GARY PIKE

575 Canora St.

North Pole, AK 99705

PLACER DOME U.S. INC.

John Barnett

P.O. Box 034357

Juneau, AK 99803

PLACID OIL CO.

J. C. Jones

3900 Thanksgiving Tower

Dallas, TX 75201

DAN \& CINDY PLANO

HC 33 Box 2872

Wasilla, AK 99687

POINTS NORTH

Robert Cacy

P.O. Box 106

Central, AK 99730

POLAR MINING INC.

Dan May (2)

4545 Woodriver Dr.

Fairbanks, AK 99709

POLAR MINING INC.

Robert Bettisworth

4545 Woodriver Dr.

Fairbanks, AK 99701
RALPH JAMES PORTER

Box 72

Soldotna, AK 99669

NEIL POWERS

9191 Old Seward Hwy., Ste. 21

Anchorage, AK 99515

WILLARD POWERS (2)

$4202 \mathrm{E}$. University Dr.

Phoenix, AZ 85034

P \& PMINE

Paul White

2551 Peede Rd.

North Pole, AK 99705

PRINCE CREEK MINING CO.

Alvin Agoff

Flat, AK 99584

$P \& S$ MINING CO.

Paul Deveny

1432 Second Ave.

Fairbanks, AK 99701

JERRY PUSHCAR

Box 160A

Nome, AK 99762

QUARTZ CREEK

EXPLORATION CO.

Milo Ellsworth Flothe

P.O. Box 242

Sterling, AK 99762

R.A. HANSON CO, INC.

R.A. Hanson (3)

P.O. Box 7400

Spokane, WA 99207

RAINBOW MINING

Demnis Gilbraeth

P.O. Box 10048

Fairbanks, AK 99710

RASMOS

Robert Rasmussen

P.O. Box 875464

Wasilla, AK 99687

(sand and gravel)

RAY BILLINGS

16035 Brown Ln.

Coltonwood, CA 96035

RB GRAVEL SALES

Gerald L. Hassel (2)

P.O. Box 49

Ester, AK 99725

(sand and gravel)

RCL MINING

Ray Vogt

2108 Central Ave.

Fairbanks, AK 99701
REDMOND MINING CO.

Richard Redmond

General Delivery

Nome, AK 99762

WADE REESE

P.O. Box 141086

Anchorage, AK 99514

LEO REGNER

P.O. Box 2733

Fairbanks, AK 99707

RESOURCE EXPLORATION

\& DEVELOPMENT

James P. Conway

$\mathrm{HCO} 2 \mathrm{Box} 7660$

Palmer, AK 99645

RGV \& BONANZA MINING

Douglas Miller

P.O. Box 127

Central, AK 99730

RICHARD BUSK \& FAMILY

Richard L. Busk

P.O. Box 100971

Anchorage, AK 99510

EARL RIDNER

P.O. Box 40154

Clear, AK 99704

LYNN \& MICHAEL RILL

2702 Kuskokwim St.

Fairbanks, AK 99701

JOHN RITTER

P.O. Box 73792

Fairbanks, AK 99707

ROBBIE'S BONANZA MINE

Roger Roberts

Mile 536 Old Iditarod Trail

Ophir, AK 99672

MICHAEL ROBERTS

P.O. Box 82182

Fairbanks, AK 99708

ROBERT ROBERTS

P.O. Box 225

Tok, AK 99780

MICHAEL STORMONT \& ROBERT ROBERTS

828 2nd Ave.

Fairbanks, AK 99701

ROCK PRODUCTS INC.

Nanette E. Arneson

P.O. Box 876010

Wasilla, AK 99687-6010

JOHN ROOP

Box 44

Chicken, AK 99732 
ROSANDER MINING CO. Ronald Rosander

Box 129

McGrath, AK 99627

ROWALLAN MINE PARTNERSHIP

Vince Halverson

P.O. Box 318

Clam Gulch, AK 99568

ROYAL OAK RESOURCES LTD.

James Prescott

200-1055 W. Hastings St.

Vancouver, BC V6E 2E9 Canada

JOHN RUBEL

8183 Richardson Hwy.

Salcha, AK 99714

ERNEST RUSSELL

P.O. Box 33

Manley Hot Springs, AK 99756

RYBACHEK MINING

Stanley Rybachek

P.O. Box 55698

North Pole, AK 99705

WILLIAM C. MORTERUD

\& WALLACE P. SALINE

P.O. Box 231

Girdwood, AK 99587

SALTER \& ASSOC. INC.

Ed Salter

Box 30

Manley Hot Springs, AK 99756

SANDVIK ENTERPRISES

Lynn Sandvik

HCO 2 Box 7480-2

Palmer, AK 99645

(sand and gravel)

HAROLD SAULE

2840 E. 142 Ave.

Anchorage, AK 99516

BUDDY SAUNDERS

1939 jack St.

Fairbanks, AK 99709

DWAYNE SAVAGE

P.O. Box 10613

Fairbanks, AK 99710

PAUL SAYER

Box 10

Homer, AK 99603

\section{ROGER SAYER}

P.O. Box 73513

Fairbanks, AK 99707

PAUL METZ, BARRYIDONNELLAN, \& RICHARD SCHMOL

P.O. Box 73606

Fairbanks, AK 99707
JOHN SCHNABEL

P.O. Box 149

Haines, AK 99827

WERNER SCHUSTER

HC 03, Box 8080

Palmer, AK 99645

JACKIE SEE

541 Riviera Ct.

Fullerton, CA 90635

GEORGE SEUFFERT

P.O. Box 156

Central, AK 99730

$S \& \mathrm{HCO}$.

Gerald L. Hassel

P.O. Box 49

Ester, AK 99725

W. SHAFFER (3)

316 Rio Verde

El Paso, TX 79912

SHANNON MERRITT

Al Cerepa

P.O. Box One

Kenai, AK 99611

DENNIS SHEPARD (2)

P.O. Box 82504

Fairbanks, AK 99708

SHORT GULCH MINING CO. LTD.

jill Taylor

P.O. Box 9

Ruby, AK 99768

SILVERADO MINES U.S. INC.

Box 12542, Ste. 2580

Vancouver, BC V6E $3 \times 2$ Canada

JOHN SIPES

2741 Perimeter Dr.

North Pole, AK 99705

SAM SKIDMORE

P.O. Box 470

Fairbanks, AK 99707

SKOOKUM MINING

John Cole

P.O. Box 10139

Fairbanks, AK 99710

SLATE CREEK MINING

Lloyd Swenson

Box 9061

Goldfoot, AK 99701-9998

JOHN SLATT

5914 Highway 30 West

The Dalles, OR 97058
HOWARD SMITH

P.O. Box 1369

Nome, AK 99762

WALTER BAGNELL \&

RANDY SMITH

7516 Zurich St.

Anchorage, AK 99507

WILLIAM SMITH

906 Cunningham

Anchorage, AK 99501

SMK-2 MINING

Michael Sweetsir

P.O. Box 170

Ruby, AK 99768

SNOW LION MINING CO.

Jemy Fabrizio

14121 Puget Sound Blvd.

Edmonds, WA 99827

HANS SOBANJA

P.O. Box 10196

Fairbanks, AK 99710

SPERNAK \& SON INC.

James Spernak

8223 Sand Lake Rd.

Anchorage, AK 99502

(sand and gravel)

SPHINX AMERICA INC. (4)

P.O. Box 81978

Fairbanks, AK 99708

SPRUCE CREEK MINING CO.

John O'Carroll

Ophir

McGrath, AK 99627

PAUL STEINHACKER

151 East 71 St.

New York, NY 10021

STEPP-A-LONG

Vem Stepp

290 Pearl Dr.

Fairbanks, AK 99712

JACKIE STEWART

209 Marika St., Apt 3

Fairbanks, AK 99701

ROSALYN STOWELL

308 Haines Ave.

Fairbanks, AK 99701

PHILIP STRANGE

P.O. BOX 871478

Wasilla, AK 99687

GARY SUPERMAN

HCO1-1510

Kenai, AK 99611
SUPERSTOCK MINING

George Superdock

P.O. Box 30088

Central, AK 99730

JAMES SWAN

452 Winter Ave.

Fairbanks, AK 99712

TOM SWARTWOOD

HC03 Box $8100 \mathrm{~L}$

Palmer, AK 99645

SWENSON MINING

Richard Swenson

P.O. Box 16082

Two Rivers, AK 99716

WAYNE TACHICK

Box 3503

Soldotna, AK 99669

TAIGA MINING CO.

415 W. 8th

Anchorage, AK 99501

NOEL S. TANNER

P.O. Box 1369

Nome, AK 99762

TAYLOR'S \& TAYLOR'S

MINING CO.

Lamy Taylor

P.O. Box 101

Eagle, AK 99738

TEGGUN MINING CO.

Paul Nelson

Rt 2 Box 753

Soldotna, AK 99669

TENNECO MINERALS CO.

5301 Longley Ln., \#113

Reno, NV 89511

THANKSGIVING MINING

John Schilling (2)

Box 8142S

Fairbanks, AK 99708

THE MINING CO.

John McClain

P.O. Box 74949

Fairbanks, AK 99707

THE MINING MANAGE-

MENT CORP.

Stella Lavender

P.O. Box 91725

Anchorage, AK 99509

MARTHA THOMAS

Box 9023

Coldfoot, AK 99701 


\section{TILLESON MINING \& RECLAMATION \\ Harold Tilleson \\ P.O. Box 55823 \\ North Pole, AK 99705 \\ TOK GOLD MINING \& EXPLORATION \\ James Steward \\ 106.5 Mile Tok Cut Off \\ Tok, AK 99780 \\ TOKLAT MINING \& EXPLORATION \\ George Jennings \\ 1200 E 68th \#102 \\ Anchorage, AK 99518 \\ CAMDEN \& CYNTHIA TOOHEY (3) \\ P.O. Box 113 \\ Girdwood, AK 99587 \\ ROBERT TOPOROWSKI \\ P.O. Box 83825 \\ Fairbanks, AK 997083825}

TRANS ALAS-CAN GOLD

3605 Artic Blvd., 1382

Anchorage, AK 99503

TREASURE CREEK MINING

Donald Read

P.O. Box 1638

Fairbanks, AK 99707

TRI-CON MINING CO.

Edward Armstrong (3)

P.O. Box 83730

Fairbanks, AK 99708

TRINITY MINING

Cheryl jong

P.O. Box 1107

Nome, AK 99762

TRI-VALLEY CORP.

Lym Blystone

2001 Westwind Dr., \#14

Bakersfield, CA 93301

ROBERT MCCLANAHAN II/III \& JOETTOM TRUDEAU

General Delivery

Chicken, AK 99732

JOHN TURNER

409 Dunkel

Fairbanks, AK 99701

ALEX TWOGOOD (2)

P.O. Box 60203

Fairbanks, AK 99706

LESLIE UNDERWOOD

Box 53

Central, AK 99730
USIBELLI COAL MINE INC.

P.O. Box 1000

Healy, AK 99743

(coal)

TOM VAN OSTRAND

P.O. Box 314

Healy, AK 99743

MICHAEL VIAL

P.O. Box 889

Candle, AK 99728

BETTY WAGNER-KRUTZSCH

P.O. Box 2496

Del Mar, CA 92014

DARRELL WALKER

56810 East End Rd.

Homer, AK 99603

GERALD WALKER

11477 Miners Wy.

Rough \& Ready, CA 95975

JOHN WALSH

P.O. Box 2095

Nome, AK 99762

MORRIS WALTERS

622E SR4

Cuthlamet, WA 98612

ROSS WALTON

1247 Hartzog Loop

North Pole, AK 99705

HELEN WARNER

P.O. BOX 80674

Fairbanks, AK 99708

JIM WATKINS

P.O. Box 2871

Palmer, AK 99645

DOUGLAS WEATHERS

P.O. Box 8082

Nikiski, AK 99635

VERNON WEAVER (2)

P.O. Box 74

Chicken, AK 99732

ANDREW WESCOTT

1132 Lakeview Terrace

Fairbanks, AK 99701

WESTERN ARTIC MINING

Kerry Blake

P.O. Box 543

Nome, AK 99762

WGMINC.

Ronald Sheardown

P.O. Box 100059

Anchorage, AK 99510
WHITE BEAR MINING

Harry Faulkner, $\mathrm{Sr}$.

P.O. Box 1307

Bethel, AK 99559

DOROTHY WILCOX

$433 \mathrm{M} \mathrm{St}$.

Anchorage, AK 99501

FRANK WILLFORD

Box 10570

Fairbanks, AK 99710

ANN WILLIAMS

Flat, AK 99584

MICHAEL WILLIAMS (2)

P.O. Box 603

Tok, AK 99780

CRAIG WILLIAMSON

1724 Old Pioneer Wy.

Fairbanks, AK 99709

DAVID WILMARTH

Box 111037

Anchorage, AK 99511

RICHARD WILMARTH

Red Devil, AK 99656

GEORGE WILSON

$\mathrm{HC} 03$ Box 8360

Palmer, AK 99645

HELEN WILSON

8446 Bearberry St.

Anchorage, AK 99502

LAURA WILSON-SHEMEL

HC 31 Box 5187 A

Wasilla, AK 99687

KENNETH WISE

General Delivery

Chicken, AK 99732

GORDON WOLFF

618 W 86th Ave.

Anchorage, AK 99515

WOLFF MINING

Robert Wolff

Boundary

Tok, AK 99780

MORRIS WOLTERS

622E SR4

Cuthlamet, WA 98612

JAMES WOOD

P.O. Box 58597

Fairbanks, AK 99711

CHARLES WOODRUFF

P.O. Box 2278

Fairbanks, AK 99707
RON WREDE

P.O. Box 71

Central, AK 99730

L.E. WYRICK

P.O. Box 261

McGrath, AK 99627

GEORGE YODER

1527 Henry St.

North Pole, AK 99705

ROBERT YOUNG

P.O. Box 211

Talkeetna, AK 99676

YUKON MINING CO. INC.

Joel Ramstad

P.O. Box 101454

Anchorage, AK 99510

YUTAN CONSTRUCTION CO.

Lewis Vondra

P.O. Box 71775

Fairbanks, AK 99707

LES PAUL ZERBE

356 Louise Ln.

Fairbanks, AK 99709

EDWARD ZIEGLER

P.O. Box 121

Central, AK 99730

GEORGE ZIMMER

P.O. Box 140174

Anchorage, AK 99514 
APPENDIX F

Primary metals production in Alaska, 1880-1990

\begin{tabular}{|c|c|c|c|c|c|c|c|c|c|c|c|c|c|c|c|c|c|c|c|c|}
\hline \multirow[b]{2}{*}{ 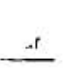 } & \multirow{2}{*}{\multicolumn{2}{|c|}{ (oz) Gold (ms) }} & \multicolumn{2}{|c|}{ Silver } & \multirow{2}{*}{\multicolumn{2}{|c|}{$\begin{array}{c}\text { Mercury } \\
\text { (flask) }\end{array}$}} & \multicolumn{2}{|c|}{ Antimony } & \multicolumn{2}{|c|}{ Tin } & \multicolumn{2}{|c|}{ Load } & \multicolumn{2}{|c|}{ Znc } & \multicolumn{2}{|c|}{ Platinum } & \multicolumn{2}{|c|}{ Copper } & \multirow{2}{*}{\multicolumn{2}{|c|}{ Chromium }} \\
\hline & & (m\$) & (02) & (\$\$) & & (1\$) & (ib) & (1\$) & (b) & (15) & (tons) & (1\$) & (tons) & (ms) & (oz) & (1\$) & (lb) & (m\$) & & \\
\hline $\begin{array}{r}1880 \\
1899 \\
\end{array}$ & $1,153,889$ & 23.85 & 496,101 & 329.0 & $\cdots$ & - & $\cdots$ & $\cdots$ & $\cdot \cdot$ & $\cdots$ & 250 & 17.0 & $\cdots$ & $\cdots$ & .. & $\cdot \cdot$ & $\cdots$ & *. & .. & .. \\
\hline 1900 & 395,030 & 8.17 & 73,300 & 45.5 & .. & .. & .. & .. & $\cdots$ & .. & 40 & 3.4 & .. & .. & $\cdots$ & $\cdot \cdot$ & . & $\cdots$ & *. & .. \\
\hline 1901 & 335,369 & 6.93 & 47,900 & 28.6 & $\cdots$ & $\cdots$ & $\cdots$ & $\cdots$ & .. & $\ddot{0}$ & 40 & 3.4 & $\cdot \cdot$ & .. & -. & .. & 250,000 & 0.04 & $\cdot \cdot$ & - \\
\hline 1902 & 400,709 & 8.28 & 92,000 & 48.5 & $\cdot \cdot$ & -. & $\cdots$ & $\cdots$ & 30,000 & 8.0 & 30 & 2.5 & .. & .. & .. & *. & 360,000 & 0.04 & $\cdot \cdot$ & -. \\
\hline 1903 & 420,069 & 8.68 & 143,600 & 77.8 & $\cdots$ & $\cdots$ & $\cdots$ & $\cdots$ & 50.000 & 14.0 & 30 & 2.5 & $\cdots$ & $\cdots$ & $\cdots$ & $\cdots$ & $1,200,000$ & 0.16 & .. & - \\
\hline 1904 & 443,115 & 9.16 & 198,700 & 114.9 & $\cdot \cdot$ & $\cdots$ & $\cdots$ & .. & 28,000 & 8.0 & 30 & 2.5 & .. & .. & .. & $\cdot \cdot$ & $2,043,586$ & 0.28 & .. & . \\
\hline 1905 & 756,101 & 15.63 & 132,174 & 80.2 & $\cdots$ & $\cdots$ & $\cdots$ & . & 12,000 & 4.0 & 30 & 2.6 & $\cdot \cdot$ & .. & -. & $\cdot \cdot$ & $4,805.236$ & 0.75 & $\cdot \cdot$ & - \\
\hline 1906 & $1,066,030$ & 22.04 & 203,500 & 136.4 & $\cdot \cdot$ & $\cdots$ & $\cdots$ & . & 68.000 & 38.6 & 30 & 3.4 & $\cdots$ & $\cdots$ & .. & $\cdots$ & $5,871,811$ & 1.13 & .. & *. \\
\hline 1907 & 936,043 & 19.35 & 149,784 & 98.8 & .. & .. & $\cdots$ & .. & 44,000 & 16.8 & 30 & 3.2 & .. & .. & .. & $\cdots$ & $6,308,786$ & 1.26 & .. & .. \\
\hline 1908 & 933,290 & 19.29 & 135,672 & 71.9 & $\cdot \cdot$ & .. & $\cdots$ & .. & 50,000 & 15.2 & 40 & 3.4 & $\cdot \cdot$ & .. & -. & .. & $4,585,362$ & 0.61 & $\cdot \cdot$ & $\cdots$ \\
\hline 1909 & 987,417 & 20.41 & 147,950 & 76.9 & $\ldots$ & $\ldots$ & $\ldots$ & $\ldots$ & 22,000 & 76 & 69 & 5.9 & $\ldots$ & $\ldots$ & $\ldots$ & $\cdots$ & $4,124,705$ & 0.54 & $\ldots$ & $\ddot{-}$ \\
\hline 1910 & 780,131 & 16.13 & 157,850 & 85.2 & $\cdots$ & .. & $\cdots$ & $\cdots$ & 20,000 & 8.3 & 75 & 6.6 & .. & .. & -. & .. & $4,241,689$ & 0.54 & $\cdots$ & -. \\
\hline 1911 & 815,276 & 16.85 & 460,231 & 243.9 & .. & .. & $\cdots$ & .. & 122,000 & 52.8 & 51 & 4.5 & . & $\cdots$ & $\cdots$ & $\cdots$ & $27,267,778$ & 3.40 & $\cdots$ & .. \\
\hline 1912 & 829,436 & 17.14 & 515,186 & 316.8 & $\cdots$ & .. & .. & $\cdots$ & 260,000 & 119.6 & 45 & 4.1 & .. & $\cdots$ & .. & $\cdots$ & $29,230,491$ & 4.82 & $\cdots$ & -. \\
\hline 1913 & 755,947 & 15.63 & 362,563 & 218.9 & $\cdots$ & .. & $\cdots$ & .. & $100,000^{\circ}$ & $44.1^{c}$ & 6 & 0.6 & .. & .. & $\cdots$ & $\cdots$ & $21,659,958$ & 3.35 & $\cdots$ & * \\
\hline 1914 & 762,596 & 15.76 & 394,805 & 218.3 & .. & .. & . & - & 208,000 & 66.6 & 28 & 1.3 & $\cdot \cdot$ & .. & .. & $\cdots$ & $21,450,628$ & 2.85 & .. & .. \\
\hline 1915 & 807,966 & 16.70 & $1,071,782$ & 543.3 & .. & $\cdots$ & 520,000 & w & 204,000 & 78.8 & 437 & 41.1 & .. & .. & $\cdots$ & $\cdots$ & $86,509,312$ & 15.14 & $\cdots$ & -. \\
\hline 1916 & 834,068 & 17.24 & $1,379,171$ & 907.4 & .. & .. & $1.200,000$ & w & 278,000 & 121.0 & 820 & 113.2 & $\cdot$. & $\cdot \cdot$ & 8 & 0.7 & $119,654,839$ & 29.50 & $\ddot{*}$ & $\ddot{*}$ \\
\hline 1917 & 709,049 & 14.66 & $1,239,150$ & $1,020.6$ & $\cdots$ & $\cdots$ & 500,000 & w & 200,000 & 123.3 & 852 & 146.6 & $\cdots$ & $\cdots$ & 53 & 5.5 & $88,793,400$ & 24.40 & 1,100 & w \\
\hline 1918 & 458,641 & 9.48 & 847,789 & 847.8 & .. & -. & 540,000 & w & 136,000 & 118.0 & 564 & 80.1 & $\cdots$ & $\cdots$ & 284 & 36.6 & $69,224,951$ & 17.10 & 1,100 & w \\
\hline 1919 & 455,984 & 9.42 & 629,708 & 705.3 & 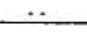 & $\cdots$ & $\ldots$ & $\ldots$ & 112,000 & 73.4 & 687 & 72.1 & $\ldots$ & $\ldots$ & 569 & 73.7 & $47,220, \pi 71$ & 8.80 & .. & $\ddot{-}$ \\
\hline 1920 & 404,683 & 8.37 & 953.546 & 1.039 .7 & $\cdots$ & $\cdots$ & $\cdots$ & $\cdots$ & 32,000 & 16.1 & 875 & 140.0 & $\cdots$ & $\cdots$ & 1,478 & 160.1 & $70,435,363$ & 13.00 & $\cdots$ & $\cdots$ \\
\hline 1921 & 390,558 & 8.07 & 761,085 & 761.1 & 45 & 1.5 & .. & $\cdots$ & 8,000 & 2.4 & 759 & 68.3 & $\cdots$ & .. & 40 & 2.7 & $57,011,597$ & 7.40 & $\cdots$ & -. \\
\hline 1922 & 359,057 & 7.42 & 729,945 & 729.9 & $\cdots$ &.. & $\cdots$ & .. & 2,800 & 0.9 & 377 & 41.5 & .. & $\cdots$ & 29 & 2.8 & $77,967,819$ & 10.50 & -. & $\cdot \cdot$ \\
\hline 1923 & 289,539 & 5.98 & 814,649 & 668.1 & .. & .. & .. & .. & 3,800 & 1.6 & 410 & 57.4 & -. & -. & $\cdots$ & .. & $85,920,645$ & 12.60 & .. & .. \\
\hline 1924 & 304,072 & 6.29 & 669,641 & 448.6 & 2 & 0.3 & $\cdots$ & .. & 14,000 & 7.1 & 631 & 100.9 & .. & .. & 28 & 2.6 & $74,074,207$ & 9.70 & $\cdots$ & .. \\
\hline 1925 & 307,679 & 6.36 & 698,259 & 482.4 & 44 & 3.6 & w & $w$ & 28,600 & 15.4 & 789 & 140.6 & $\cdot \cdot$ & .. & 10 & 1.2 & $73,055,298$ & 10.30 & $\cdot \cdot$ & .. \\
\hline 1926 & 324,450 & 6.70 & 605,190 & 377.0 & 22 & 17 & $w$ & $w$ & 16,000 & 10.4 & 778 & 124.4 & .. & .. & 3.570 & 274.5 & $67,778,000$ & 9.49 & .. & .. \\
\hline 1927 & 286,720 & 5.97 & 350,430 & 215.0 & $\cdots$ & $\cdots$ & .. & -. & 53,400 & 34.0 & 1,008 & 127.0 & $\cdots$ & $\cdots$ & . & .. & $55,343,000$ & 7.25 & $\cdots$ & .. \\
\hline 1928 & 331,140 & 6.85 & 351,730 & 187.0 & $\because$ & $\ddot{0}$ & $\cdot \cdot$ & .. & 82,000 & 41.0 & 1,019 & 118.0 & -. & $\cdots$ & 120 & 9.0 & $41,421,000$ & 5.96 & $\cdot \cdot$ & $\cdot \cdot$ \\
\hline 1929. & 375,438 & 7.76 & 472,900 & 252.0 & 4 & 0.5 & $\ldots$ & $\therefore$ & 77.200 & 35.0 & 1,315 & 166.0 & $\ldots$ & $\ldots$ & 475 & 32.0 & $40,570,000$ & 7.13 & $\cdots$ & - \\
\hline 1930 & 408,983 & 8.47 & 408,570 & 157.3 & $\cdots$ & $\because$ & .. & $\cdots$ & 29,400 & 9.3 & 1,365 & 136.5 & .. & -. & .. & .. & $32,651,000$ & 4.24 & $\cdots$ & .. \\
\hline 1931 & 459,000 & 9.51 & 352,000 & 102.0 & 15 & 1.2 & $\cdots$ & $\cdot \cdot$ & 8.200 & 2.0 & 1,660 & 126.0 & .. & $\cdots$ & 393 & 14.0 & $22,614,000$ & 1.88 & $\cdot \cdot$ & .. \\
\hline 1932 & 493,860 & 10.20 & 234,050 & 66.0 & 8 & 0.5 & $\cdots$ & .. & $\cdots$ & .. & 1,260 & 75.6 & .. & .. & .. & $\cdots$ & $8,738,500$ & 0.55 & -. & -. \\
\hline 1933 & 469,286 & 9.70 & 154,700 & 55.0 & -. & .. & .. & .. & 5,800 & 2.3 & 1,157 & 85.6 & .. & -. & 605 & 18.6 & 29,000 & 0.02 & .. & *. \\
\hline 1934 & 537,281 & 8.78 & 154,700 & 100.0 & $\cdots$ & $\cdots$ & $\cdots$ & $\cdots$ & $8.200^{C}$ & 4.3 & 839 & 62.1 & $\cdots$ & $\cdots$ & 2,555 & 85.6 & 121,000 & 0.06 & .. & .. \\
\hline 1935 & 469,495 & 16.43 & 286.600 & 206.0 & .. & .. & -. & .. & 98,800 & 49.8 & 815 & 65.2 & .. & .. & 8,685 & 259.6 & $15,056,000$ & 1.25 & .. & .. \\
\hline 1936 & 540.580 & 18.92 & 484,306 & 375.0 & .. & .. & . & .. & 226,000 & 105.0 & 941 & 86.6 & .. & .. & 5,654 & 241.9 & $39,267,000$ & 3.72 & $\cdot \cdot$ & *. \\
\hline 1937 & 627,940 & 21.98 & 494,340 & 382.0 & . & .. & 962,000 & 147.6 & $372,000^{\circ}$ & $202.3^{c}$ & 823 & 97.1 & $\cdots$ & $\cdots$ & 9,823 & 313.4 & $36,007,000$ & 4.74 & .. & -. \\
\hline 1938 & 662,000 & 23.17 & 479,853 & 310.0 & 8 & 0.6 & 444,000 & 54.8 & 210,000 & 89.1 & 994 & 91.5 & .. & .. & 41,000 & 2.460 .0 & $29,760,000$ & 2.98 & $\cdot \cdot$ & . \\
\hline 1939 & 676.780 & 23.68 & 201,054 & 136.5 & & & 210,000 & 25.9 & 66,000 & 38.0 & 937 & 88.1 & $\cdots$ & .. & 33,900 & $2,034.0$ & 278,500 & 0.04 & .. & . \\
\hline 1940 & 755,900 & 26.45 & 191,679 & 136.3 & $156^{c}$ & 130.9 & 306,000 & 42.8 & 92,000 & 52.0 & 840 & 72.0 & .. & .. & 28,886 & 1.093 .0 & 110,000 & 0.02 & $\cdot \cdot$ & $\cdots$ \\
\hline 1941 & 692,314 & 24.23 & 199,700 & 142.0 & $w$ & w & 774,000 & 87.3 & $93,600^{c}$ & $61.0^{\circ}$ & 742 & 58.0 & .. & .. & 22,630 & 813.0 & 144.000 & 0.02 & -. & -. \\
\hline 1942 & 487,657 & 17.07 & 135,200 & 96.0 & w & w & 316,000 & 41.0 & 5,600 & 2.5 & 523 & 44.0 & .. & .. & 22,000 & 779.0 & 48.000 & 0.01 & .. & $\ldots$ \\
\hline 1943 & 99,583 & 3.49 & 31,700 & 22.0 & 786 & 153.4 & 368,000 & 33.3 & $2,000^{c}$ & $1.0^{c}$ & 200 & 22.0 & .. & .. & 27,900 & 1.020 .0 & 54.000 & 0.01 & 5,564 & 186.3 \\
\hline 1944 & 49,296 & 1.73 & 15,240 & 10.8 & 841 & 165.0 & 70,080 & 30.0 & .. & .. & 44 & 5.8 & .. & .. & 33.616 & 2.017 .0 & 4,000 & 0.01 & 1,845 & 64.6 \\
\hline 1945 & 68,117 & 2.38 & 9,983 & 6.2 & 275 & 180.0 & w & w & .. & .. & 11 & 1.8 & .. & -. & 22,949 & $1,377.0$ & 10,000 & 0.01 & .. & .. \\
\hline 1946 & 226,781 & 7.93 & 41,793 & 26.3 & 699 & 68.7 & w & W & 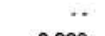 & $\cdots$ & 115 & 25.0 & $\ddot{x}$ & $\cdots$ & 22,882 & 1.418 .7 & 4,000 & 0.01 & $\cdot \cdot$ & $\cdot \cdot$ \\
\hline 1947 & 279,988 & 9.79 & 66,150 & 46.3 & 127 & 10.6 & 52,000 & 16.1 & 2,000 & 2.2 & 255 & 76.5 & 226 & 0.15 & 13,512 & 1.351 .2 & 24,000 & 0.06 & $\cdots$ & .. \\
\hline 1948 & 248,395 & 8.69 & 67,341 & 58.7 & 108 & 7.8 & 88,000 & 29.3 & 10,000 & 10.8 & 317 & 88.9 & 226 & 0.15 & 13.741 & $1,209.2$ & 28,000 & 0.07 & .. & 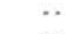 \\
\hline 1949 & 229,416 & 8.03 & 36,056 & 32.4 & 102 & 79 & 88,000 & 31.3 & 114,000 & 100.8 & 49 & 11.2 & 226 & 0.15 & 17,169 & 1.545 .2 & 7,700 & 0.02 & $\therefore$ & \\
\hline
\end{tabular}




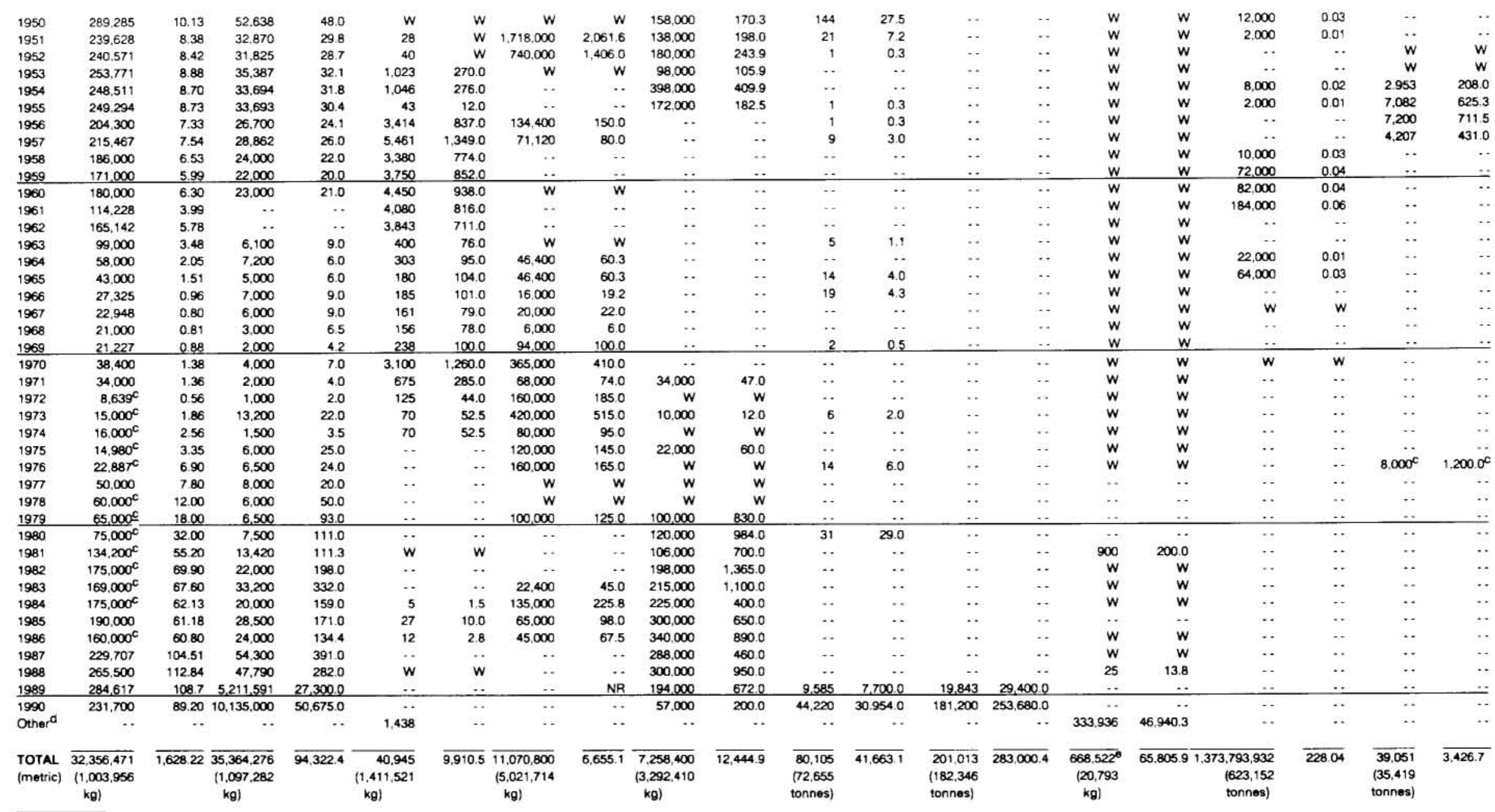

afrom 34 state and tederal documents.

b 76 -1b flask.

When state and tederai figures differ significantly, state figures are used.

dNot tracoable by year.

'Crude platinum; total production of refined metal is about $575,000 \mathrm{oz}$.

$\mathrm{W}=$ Withheld

= Thousand dollars.

$\mathrm{ms}=$ Million dollars. 
APPENDIX G

Production of industrial minerals, coal, and other commodities in Alaska, 1880-1990

\begin{tabular}{|c|c|c|c|c|c|c|c|c|c|}
\hline \multirow[t]{2}{*}{ Year } & \multicolumn{2}{|c|}{ Coal } & \multicolumn{2}{|c|}{ Sand and gravel } & \multicolumn{2}{|c|}{ Building stone } & \multicolumn{2}{|c|}{ Barite } & \multirow{2}{*}{$\frac{\text { Other }}{(\$)}$} \\
\hline & (s. tons) & $(\mathrm{m} \$)$ & (s. tons) & $(\mathrm{m} \$)$ & (s. tons) & $(\mathrm{m} \$)$ & (s. tons) & $(\$ \$)$ & \\
\hline $\begin{array}{c}1880 \\
1899^{\circ} \\
\end{array}$ & 19,429 & 0.14 & -- & $\cdots$ & 7,510 & 0.04 & $\cdots$ & $\cdots$ & - \\
\hline 1900 & $1,200^{d}$ & $0.02^{\mathrm{d}}$ & $-\cdot$ & $\cdots$ & 510 & 0.01 & $\cdots$ & $-\cdot$ & - \\
\hline 1901 & $1,300^{d}$ & $0.02^{d}$ & - & $\cdots$ & 700 & 0.01 & $\cdots$ & -. & 500 \\
\hline 1902 & $2,212^{\mathrm{d}}$ & $0.02^{d}$ & - & .. & 800 & 0.01 & $\cdots$ & $-\cdot$ & 255 \\
\hline 1903 & 1,447 & 0.01 & -- & -. & 920 & 0.01 & $\cdots$ & $\cdots$ & 389 \\
\hline 1904 & 1,694 & 0.01 & $\cdots$ & $\cdots$ & 1,080 & 0.02 & $-\cdot$ & $-\cdot$ & 2,710 \\
\hline 1905 & 3,774 & 0.02 & $\cdots$ & $\cdots$ & 970 & 0.02 & $-\cdot$ & $-\cdot$ & 740 \\
\hline 1906 & 5,541 & 0.02 & $\cdots$ & $\cdots$ & 2,863 & 0.03 & $-\cdot$ & -- & 19,965 \\
\hline 1907 & 10,139 & 0.05 & & $\cdots$ & 3,899 & 0.03 & $\cdots$ & -- & 54,512 \\
\hline 1908 & $3,107^{d}$ & $0.01^{d}$ & $\cdots$ & -. & 2,176 & 0.03 & $-\cdot$ & - & 81,305 \\
\hline 1909 & 2,800 & 0.02 & $\cdots$ & $\ldots$ & 1,400 & 0.01 & $\ldots$ & $\ldots$ & 86,027 \\
\hline 1910 & $1,000^{d}$ & $0.01^{d}$ & $\cdots$ & $\ldots$ & W & $w$ & $\cdots$ & $\cdots$ & 96,408 \\
\hline 1911 & $900^{d}$ & $0.01^{\mathrm{d}}$ & $\cdots$ & $\cdots$ & W & W & -. & $\cdots$ & 145,739 \\
\hline 1912 & $355^{d}$ & $0.01^{\mathrm{d}}$ & - & -. & W & $w$ & $-\cdot$ & $\cdots$ & 165,342 \\
\hline 1913 & 2,300 & 0.01 & -. & - & W & W & - & - & 286,277 \\
\hline 1914 & 1,190 & 0.01 & -. & $\cdots$ & W & w & -. & $\cdots$ & 199,767 \\
\hline 1915 & 1,400 & 0.03 & - & $\cdots$ & w & W & - & $\cdots$ & 205,061 \\
\hline 1916 & 12,676 & 0.05 & - & - & W & W & $\cdots$ & $\cdots$ & 326,731 \\
\hline 1917 & 54,275 & 0.27 & $-\cdot$ & $\cdots$ & W & W & $\cdots$ & -. & 203,971 \\
\hline 1918 & 75,816 & 0.41 & - & -. & W & W & $\cdots$ & - & 171,452 \\
\hline 1919 & 60,894 & 0.35 & $\cdots$ & $\ldots$ & 50,014 & 0.29 & $\ldots$ & $\ldots$ & 214,040 \\
\hline 1920 & 61,111 & 0.36 & $\cdots$ & $\cdots$ & 37,044 & 0.27 & $\cdots$ & $\ldots$ & 372,599 \\
\hline 1921 & 76,817 & 0.49 & - & -. & 59,229 & 0.31 & - & $\cdots$ & 235,438 \\
\hline 1922 & 79,275 & 0.43 & $-\cdot$ & $\cdots$ & 54,251 & 0.30 & -. & $\cdots$ & 266,296 \\
\hline 1923 & 119,826 & 0.76 & $-\cdot$ & -. & 83,586 & 0.41 & -- & - & 229,486 \\
\hline 1924 & 99,663 & 0.56 & $\cdots$ & -. & 35,294 & 0.26 & -- & - & 348,728 \\
\hline 1925 & 82,868 & 0.40 & -. & -. & 32,193 & 0.19 & - & $\cdots$ & 454,207 \\
\hline 1926 & 87,300 & 0.46 & $\cdots$ & - & 33,283 & 0.20 & $\cdots$ & - & 423,000 \\
\hline 1927 & 104,300 & 0.55 & $\cdots$ & - & 41,424 & 0.22 & $\cdots$ & $\cdots$ & . \\
\hline 1928 & 126,100 & 0.66 & $\cdots$ & - & 63,347 & 0.31 & $\cdots$ & -- & - \\
\hline 1929 & 100,600 & 0.53 & $\cdots$ & $\ldots$ & 54,766 & 0.26 & $\ldots$ & $\ldots$ & 194,000 \\
\hline 1930 & 120,100 & 0.63 & $\cdots$ & - & 66,234 & 0.33 & $\cdots$ & $\cdots$ & 157,300 \\
\hline 1931 & 105,900 & 0.56 & - & $\cdots$ & 59,175 & 0.29 & $\cdots$ & $\cdots$ & 108,000 \\
\hline 1932 & 102,700 & 0.53 & $-\cdot$ & $\cdots$ & 54,167 & 0.27 & $\cdots$ & $\cdots$ & 223,400 \\
\hline 1933 & 96,200 & 0.48 & - & - & 56,291 & 0.28 & $\cdots$ & $\cdots$ & - \\
\hline 1934 & 107,500 & 0.45 & $-\cdot$ & $-\cdot$ & 64,234 & 0.36 & $\cdots$ & $\cdots$ & 46,155 \\
\hline 1935 & 119,425 & 0.50 & $-\cdot$ & $\cdots$ & 74,049 & 0.38 & $\cdots$ & $\cdots$ & 46,755 \\
\hline 1936 & 136,593 & 0.57 & $\cdots$ & $\cdots$ & 76,379 & 0.38 & $\cdots$ & $\cdots$ & 45,807 \\
\hline 1937 & 131,600 & 0.55 & -- & -. & 50,057 & 0.25 & $\cdots$ & - & 147,048 \\
\hline 1938 & 159,230 & 0.62 & - & -. & 189,090 & 0.21 & $\cdots$ & $-\cdot$ & 125,302 \\
\hline 1939 & 143.549 & 0.60 & 42.332 & 0.02 & $\ldots$ & .. & $\ldots$ & $\ldots$ & .. \\
\hline 1940 & 170,174 & 0.88 & 515,011 & 0.10 & $\cdots$ & $\cdots$ & $\cdots$ & $\cdots$ & $\cdots$ \\
\hline 1941 & 241,250 & 0.97 & 530,997 & 0.09 & $\cdots$ & - & $\cdots$ & .. & $1,367,000$ \\
\hline
\end{tabular}

-Building-stone production figures for 1880-1937 are for the southcentral and interior regions of Alaska only.

IIncludes 2.4 million lb $\mathrm{U}_{3} \mathrm{O}_{8}$ (1955-71); 505,000 tons gypsum (1905-26); 286,000 lb WO (intermittently 1916-80); 94,000 lb asbestos (1942-44); 540,000 lb graphite (1917-18; and 1942-50); and undistributed amounts of zinc, jade, peat, clay, soapstone, miscellaneous gemstones, and other commodities (1880-1985).

cProduction not traceable by year.

'When state (territorial) and federal figures differ significantly, state figures are used. Figures for sand and gravel production in 1974 show state estimates $(118,740,000 \mathrm{~s}$. tons; $240.94 \mathrm{mS})$ and federal $(42,614,000 \mathrm{~s}$. tons; $88.96 \mathrm{mS})$. The federal estimate was not added to total production.

- Marble quarried on Prince of Wales Island, southeastern Alaska (1900-41).

m\$ - Million dollars.

ts - Thousand dollars.

- - Not reported.

W - Withheld. 


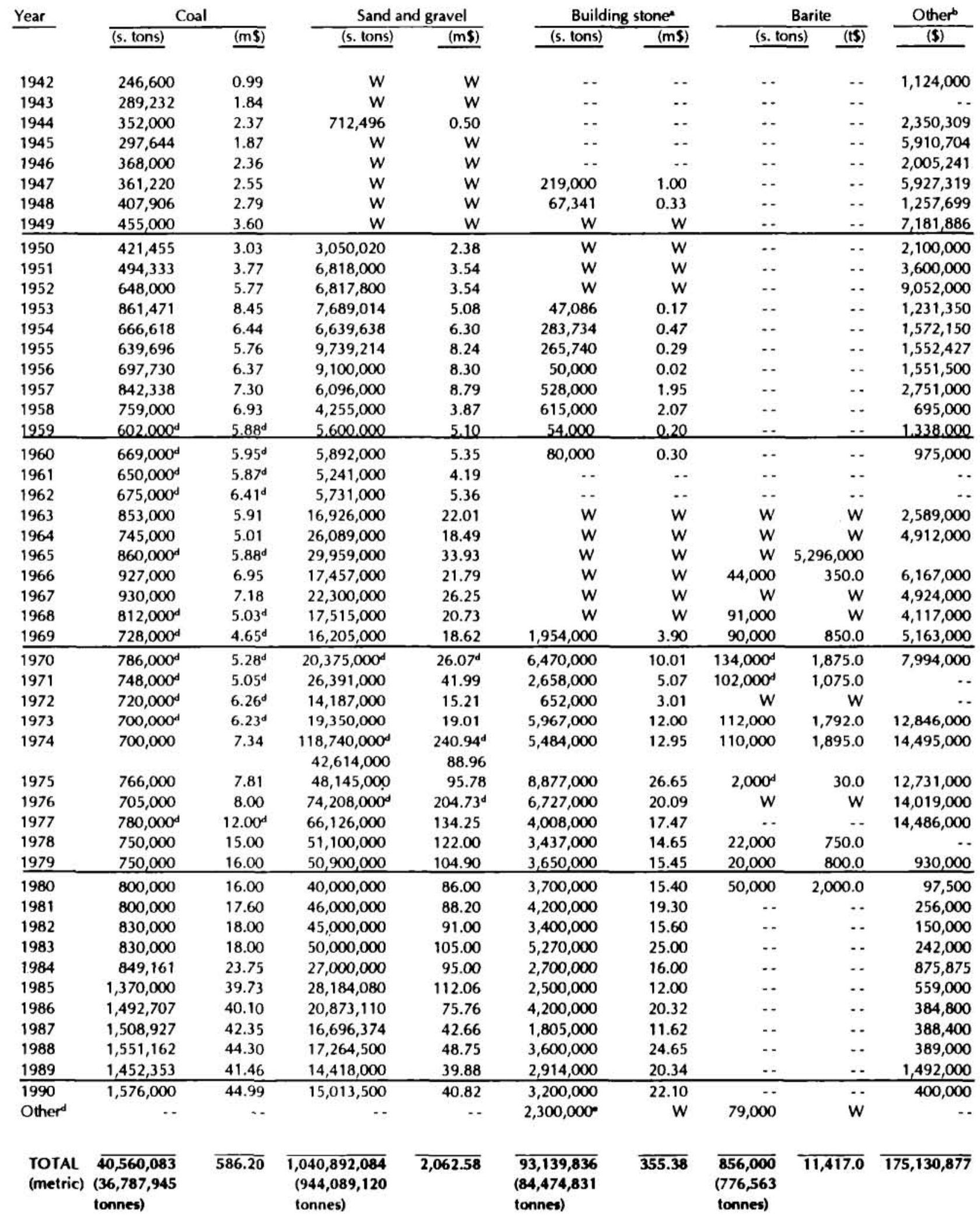




\section{METRIC CONVERSION FACTORS}

Factors for converting U.S. customary units to international metric units are as follows:

\begin{tabular}{|c|c|c|}
\hline To convert from & To & Multiply by \\
\hline \multicolumn{3}{|c|}{ MASS } \\
\hline $\begin{array}{l}\text { ounce, troy (oz tr) } \\
\text { ounce, avoirdupois (oz avdp) } \\
\text { pound, avoirdupois (lb) } \\
\text { ton, short }(2,000 \mathrm{lb}) \\
\text { tonne }(\mathrm{mg})\end{array}$ & $\begin{array}{l}\text { kilogram (kg) } \\
\text { kilogram (kg) } \\
\text { kilogram }(\mathrm{kg}) \\
\text { tonne }(\mathbf{m g}) \\
\text { ton }(2,000 \mathrm{lb})\end{array}$ & $\begin{array}{r}0.0311 \\
0.0283 \\
0.4536 \\
0.9072 \\
1.102\end{array}$ \\
\hline \multicolumn{3}{|c|}{ LENGTH } \\
\hline $\begin{array}{l}\text { foot (ft) } \\
\text { mile (mi) }\end{array}$ & $\begin{array}{l}\text { meter }(\mathrm{m}) \\
\text { kilometer }(\mathrm{km})\end{array}$ & $\begin{array}{r}0.3048 \\
1.609\end{array}$ \\
\hline \multicolumn{3}{|c|}{ AREA } \\
\hline $\begin{array}{l}\operatorname{mile}^{2}\left(\mathrm{mi}^{2}\right) \\
\text { acre }\end{array}$ & $\begin{array}{l}\text { kilometer }{ }^{2}\left(\mathrm{~km}^{2}\right) \\
\text { hectometer }\left(\mathrm{hm}^{2}\right)\end{array}$ & $\begin{array}{l}2.590 \\
.4047\end{array}$ \\
\hline \multicolumn{3}{|c|}{ VOLUME } \\
\hline $\begin{array}{l}\text { yard' }\left(y d^{3}\right) \\
\text { gallon }\end{array}$ & $\begin{array}{l}\text { meter' }\left(m^{\prime}\right) \\
\text { liter }\end{array}$ & $\begin{array}{r}0.7646 \\
3.785\end{array}$ \\
\hline
\end{tabular}


ALASKA IN TRUE SCALE COMPARED WITH THE LOWER 48

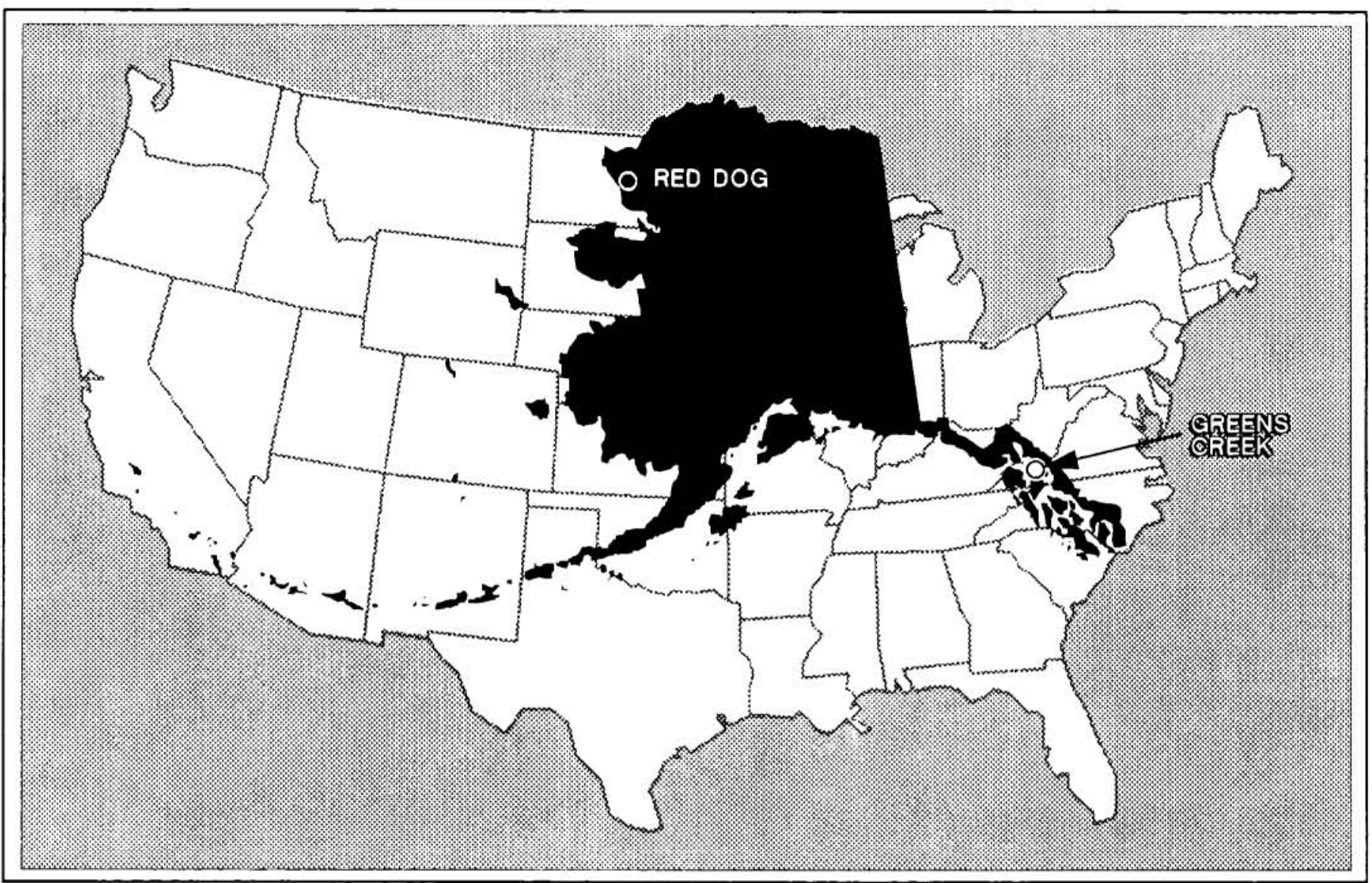






